Comprehensive Inventory and Determinations of Eligibility for Fort Riley Buildings: 18571963

Susan I. Enscore and Julie L. Webster

September 2009

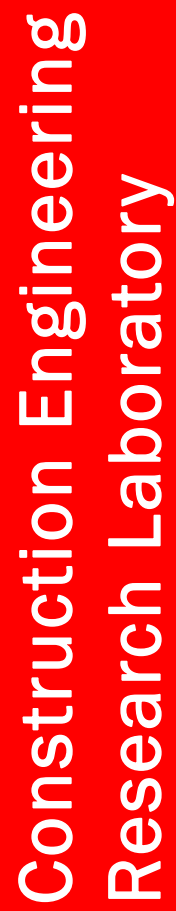

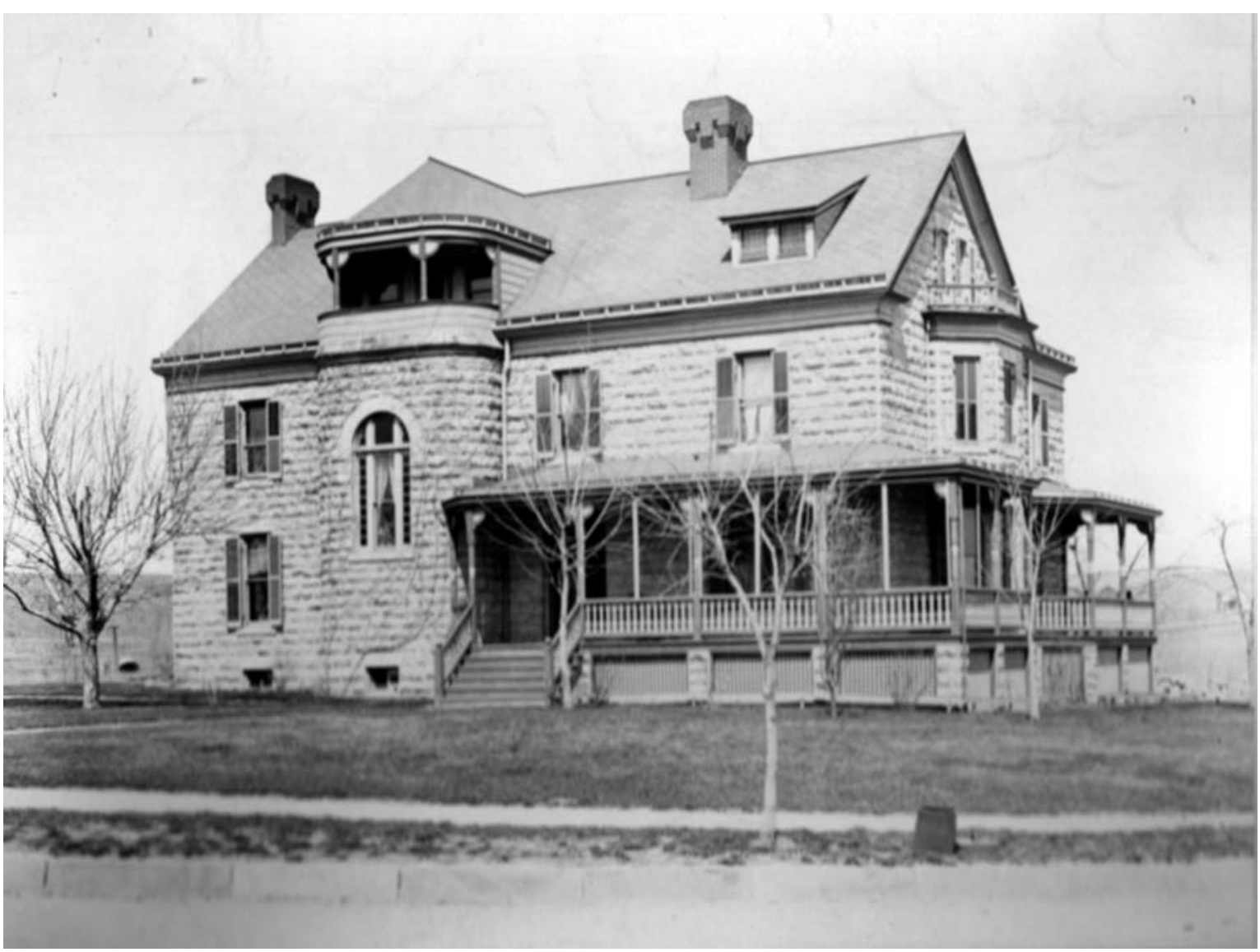





\section{Comprehensive Inventory and Determinations of Eligibility for Fort Riley Buildings: 1857-1963}

Susan I. Enscore and Julie L. Webster

Construction Engineering Research Laboratory

U.S. Army Engineer Research and Development Center

2902 Newmark Drive

Champaign, IL 61822

Final report

Approved for public release; distribution is unlimited.

Prepared for Conservation and Restoration Branch

Environmental Division

Fort Riley, Kansas, 66442

Under Work Unit 146503 


\begin{abstract}
This report represents the public release version of ERDC/CERL TR-09-37: "Comprehensive Historical and Architectural Documentation Report for Fort Riley, Kansas.” It inventories all buildings and structures constructed at Fort Riley, Kansas, from 1855- 1963, with the exception of buildings already covered under national Advisory Council on Historic Preservation (ACHP) Program Comments. In three separate studies (1993-1994, 2007, and 2008), ERDC-CERL inventoried and evaluated 373 properties on the installation that were constructed during 1855- 1963. Determinations of Eligibility (DOE) to the National Register of Historic Places (NRHP) were then made, based on the significance of the buildings and the degree to which they retain their integrity for conveying that significance. As a result, 272 of those buildings and structures have been determined to be eligible for inclusion in the NRHP.
\end{abstract}

DISCLAIMER: The contents of this report are not to be used for advertising, publication, or promotional purposes. Citation of trade names does not constitute an official endorsement or approval of the use of such commercial products. All product names and trademarks cited are the property of their respective owners. The findings of this report are not to be construed as an official Department of the Army position unless so designated by other authorized documents.

DESTROY THIS REPORT WHEN NO LONGER NEEDED. DO NOT RETURN IT TO THE ORIGINATOR. 


\section{Table of Contents}

List of Figures and Tables.

Preface. ..$v i$

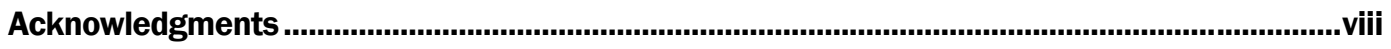

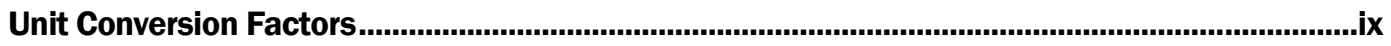

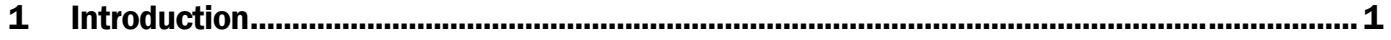

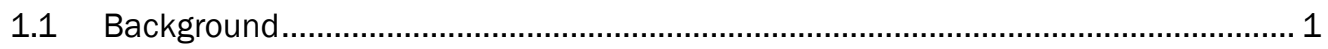

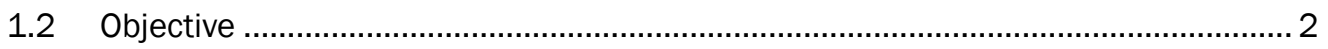

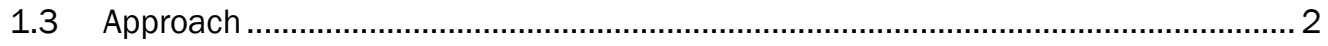

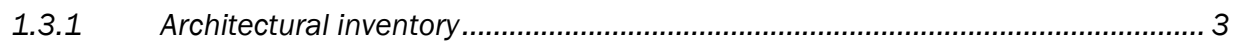

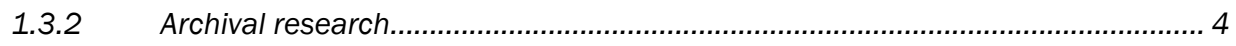

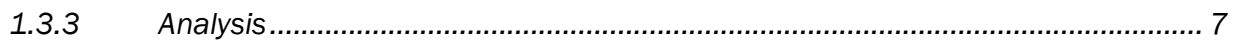

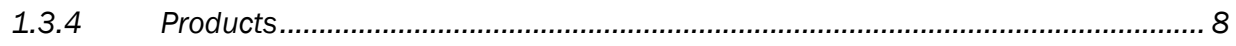

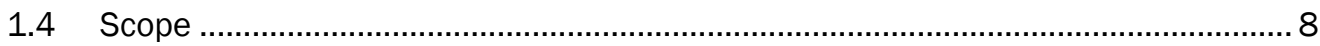

2 The Historic Context for Fort Riley Development, 1852 - 1963 .........................................10

2.1 Establishment of Fort Riley ........................................................................ 11

2.2 Early construction ......................................................................................... 13

2.3 Early limestone construction at Fort Riley...................................................... 14

2.4 Contractors and workers .......................................................................... 14

2.5 Remaining buildings from initial construction period.......................................... 15

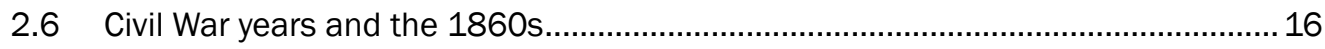

2.7 Construction of the cavalry and artillery posts .................................................. 19

2.8 Captain Pond and Army standardized plans ......................................................25

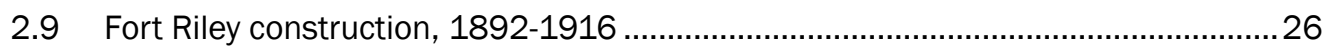

2.10 Limestone construction at Fort Riley, 1886-1916 ............................................ 27

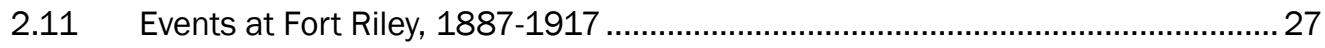

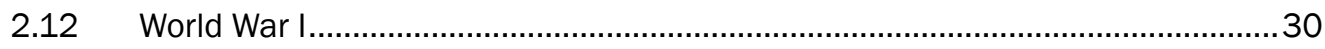

2.13 Between the World Wars ................................................................................ 31

2.14 Construction at Fort Riley, 1927-1940..............................................................33

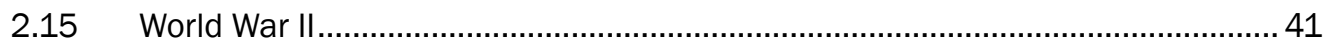

2.16 The Cold War begins ................................................................................ 44

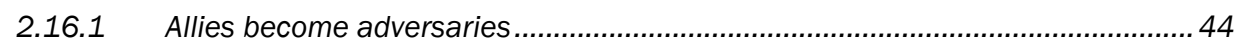

2.16.2 Korean War, 1950-1953 .............................................................................. 46

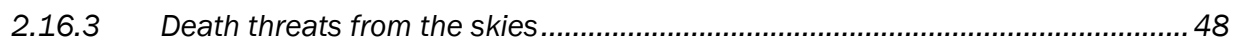

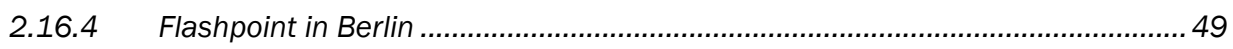

2.16.5 Geopolitical competition and proxy wars ...........................................................50

$2.17 \quad$ Early Cold War years at Fort Riley ......................................................................52

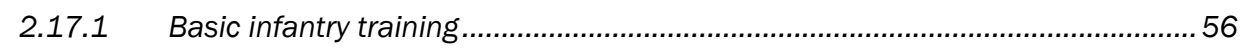

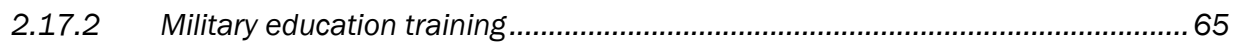


2.17.3 Postwar construction at Fort Riley ...................................................................... 70

2.18 Fort Riley between Korea and Vietnam ...................................................... 77

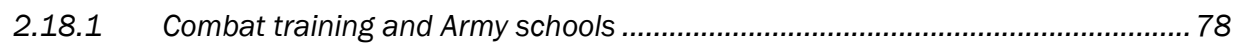

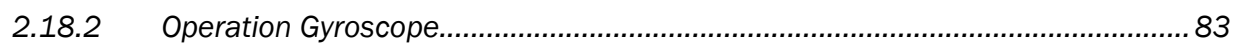

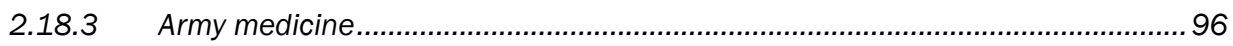

2.18.4 Army aviation ................................................................................................ 102

2.19 Army reorganizes and gets combat-ready ................................................108

2.19.1 Mission requirements .............................................................................. 108

2.19.2 Combat-ready training ............................................................................... 110

2.19.3 Fort Riley construction in the early 1960s....................................................115

3 Architectural Overview of Significant Buildings Constructed 1953-1960 ..................... 121

3.1 Marshall Army Air Field infrastructure ...................................................................122

3.1.1 Aircraft hangar: Building 723.................................................................... 122

3.1.2 Operations building: Building 725.............................................................. 124

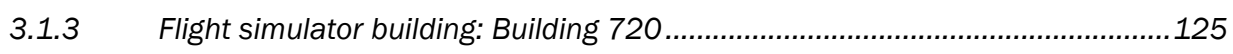

4 Determinations of Eligibility to the National Register ................................................. 128

4.1 Identification of significance............................................................................ 128

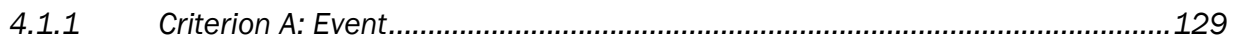

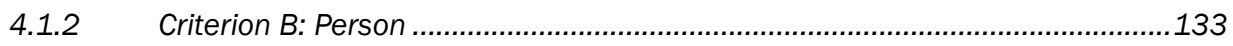

4.1.3 Criterion C: Design/construction ................................................................133

4.1.4 Criterion D: Information potential...................................................................133

4.1.5 State or local significance.............................................................................. 134

4.1.6 Significant buildings and structures............................................................134

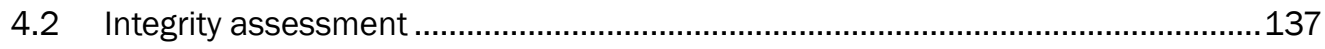

4.3 Determinations of Eligibility ...................................................................... 137

4.4 Marshall Army Air Field .....................................................................................138

5 Recommendations for Organization and Management of Eligible Properties................ 139

5.1 Proposed historic districts.........................................................................139

5.2 Recommendations for the treatment and further research of historic structures at Fort Riley ............................................................................................ 141

5.3 Recommendation Summary .....................................................................142

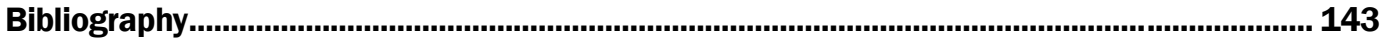

Appendix A: NHPA Methodology for Determining Eligibility of Historic Buildings and Levels of District Contribution (1993 Study) ................................................................157

Appendix B: All Buildings and Structures at Fort Riley Inventoried and Evaluated by ERDC-CERL as of September 2009................................................................................ 161

Appendix C: Integrity Review for Properties Declared Eligible in 1993....................................172

Appendix D: Proposed Historic Districts at Fort Riley, 1993 Study ..................................... 181

Appendix E: Proposed Historic Districts and Thematic Groups (Revised, 1994) ................... 195 


\section{List of Figures and Tables}

\section{Figures}

Figure 1. Map of Fort Riley, 2007 (http://www.riley.army.mil/OurPost/Maps.asp.mil)...................... 2

Figure 2. 1867 Plan of Fort Riley (prepared by ERDC-CERL, based on NARA original).................... 17

Figure 3. Cavalry and Artillery Posts Plan for Fort Riley (largely implemented), 1887 (CERL

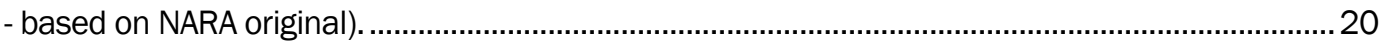

Figure 4. Cavalry barracks in undated view (NARA) ......................................................................... 21

Figure 5. Cavalry stable in undated view (NARA) ........................................................................... 21

Figure 6. Commandant's Quarters, Bldg 1, circa 1900 (NARA). ..................................................... 22

Figure 7. Field Officers' housing at Fort Riley, circa 1900 (NARA)...................................................2

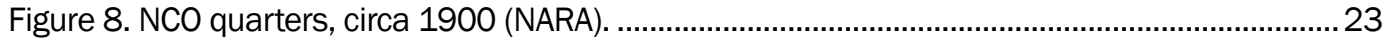

Figure 9. Artillery barracks in undated view (NARA) ................................................................. 24

Figure 10. Cavalry pistol practice, 1927 (NARA). ............................................................................ 29

Figure 11. Panorama of Camp Funston, 1918 (Library of Congress)............................................. 31

Figure 12. Jumping exercises at Fort Riley, undated (NARA)....................................................... 32

Figure 13. Camp Funston under water, July 16, 1951 (NARA). ....................................................54

Figure 14. Marshall Field on July 16, 1951 (NARA) ............................................................... 54

Figure 15. WAC receives a high score at the rifle range, 1951 (NARA)........................................... 60

Figure 16. Tank supported 10th Division trainees move on an enemy held town in urban

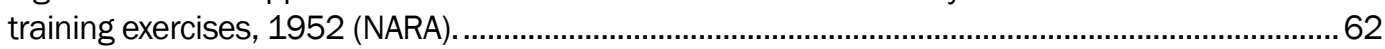

Figure 17. Basic combat training, 1952 (NARA)................................................................... 63

Figure 18. An Aggressor soldier being led away by an American force, 1950 (NARA).....................64

Figure 19. Building 2101, new telephone exchange building, Camp Forsyth, 1954 (NARA)............ 77

Figure 20. Rifle Range Training at Fort Riley, 1953 (NARA)........................................................ 80

Figure 21. Training on the zero distance TRAINFIRE Range at Fort Stewart, Georgia, 1966

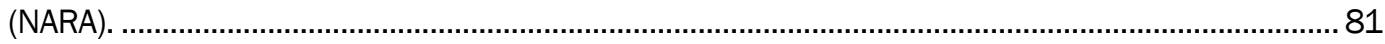

Figure 22. Completed Hammerhead barracks, mid-1950s (Museum Division, Fort Riley)..............89 89

Figure 23. Barracks construction at Custer Hill, 1955 (Museum Division, Fort Riley)......................90

Figure 24. Enlisted Service Club at Custer Hill, 1965 (NARA)...........................................................92

Figure 25. Custer Hill Chapel, 1968 (NARA)............................................................................... 92

Figure 26. Craig Field House, Custer Hill, 1968 (Museum Division, Fort Riley)................................93

Figure 27. Theater \#5, Custer Hill, 1965 (NARA)..................................................................... 94

Figure 28. Administration/supply Building 7243, Custer Hill, 1965 (NARA)...................................94

Figure 29. Custer Hill Troop Area, 1967 (Museum Division, Fort Riley).............................................95

Figure 30. Irwin Army Hospital, Fort Riley, 1960 (NARA)...........................................................100

Figure 31. Pneumatic tube distribution/communication system, Irwin Army Hospital, Fort Riley, 1957 (NARA). 101 
Figure 32. Mrs. Clara Irwin, granddaughter-in-law of Brigadier General Irwin, at dedication of Irwin Army Hospital, 7 February 1958 (NARA) .........................................................................102

Figure 33. Cargo helicopter training at Fort Riley, 1956 (NARA) . ................................................105

Figure 34. Marshall Army Air Field, 1957 (Museum Division, Fort Riley). ...................................... 107

Figure 35. Monteith Heights housing, 1966 (NARA). .............................................................. 116

Figure 36. Warner Heights (left), Peterson Heights (center), and Monteith Heights (right),

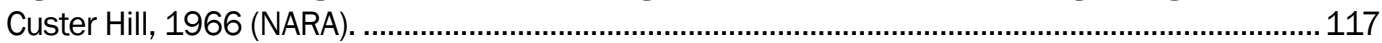

Figure 37. Warner Heights housing, 1966 (NARA) ........................................................................ 117

Figure 38. Definitive design for the smaller Army Air Cavalry hangar (ERDC-CERL 1999).............123

Figure 39. Fort Riley aircraft hanger: Building 723 (ERDC-CERL 2007).......................................124

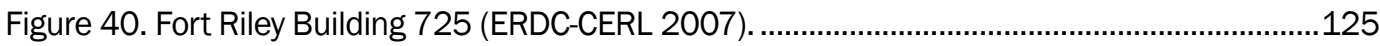

Figure 41. Fort Riley Building 720, south and east elevations (ERDC-CERL 2007). .......................127

Figure 42. Map of Main Post showing Historic District boundaries (DPW, Fort Riley, Kansas) 140

\section{Tables}

Table 1. Character-defining features of recommended eligible Marshall Field buildings...............122

Table 2. List of Significant/Not Significant Buildings.....................................................................134

Table 3. Retention of Integrity............................................................................................... 137

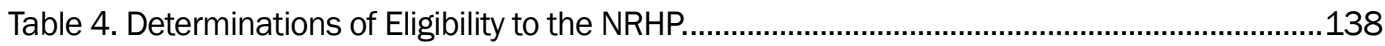

Table 5. Buildings and Structures Determined Eligible to the NRHP.................................................161

Table 6. Buildings and Structures Determined Not Eligible to the NRHP.........................................168

Table 7. Reassessment of integrity: Original Post Thematic Group ................................................. 172

Table 8. Reassessment of integrity: Cavalry and Artillery Thematic Group ...................................172

Table 9. Reassessment of integrity of the 1927-1940 Thematic Group. .................................... 176

Table 10. Reassessment of integrity of the WPA Camp Thematic Group....................................180

Table 11. Reassessment of integrity of the World War II Build-Up Thematic Group.......................180

Table 12. Cavalry Post: District Membership and Ratings...........................................................182

Table 13. Artillery Post: District Membership and Ratings.........................................................185

Table 14. QM Supply/Service District: District Membership and Ratings.....................................187

Table 15. Hospital/Post Headquarters District: District Membership and Ratings.........................188

Table 16. Marshall Army Airfield: District Membership and Ratings..............................................189

Table 17. Officers' Family Housing District: District Membership and Ratings...............................190

Table 18. Student Officers' Apartments District: District Membership and Ratings. ......................192

Table 19. Packer's Camp: District Membership and Ratings. ......................................................194

Table 20. Original Post Thematic Group...................................................................................... 197

Table 21. Cavalry and Artillery Thematic Group ................................................................................ 197

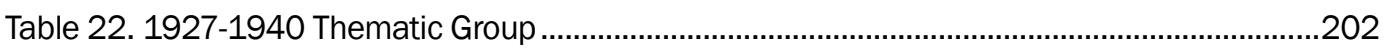

Table 23. WPA Camp Thematic Group .....................................................................................205

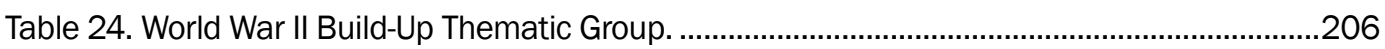

Table 25. Recommended Non-Contributing Buildings Ineligible for NRHP....................................206 


\section{Preface}

This study was conducted for the Conservation and Restoration Branch, Environmental Division, Fort Riley, Kansas, under project 146503, "Fort Riley Building Evaluation Update." Funding was provided by Military Interdepartmental Purchase Request MIPR7KDATENV14, dated 27J une 2007. The Fort Riley technical monitor was Ed Hooker III, IMNW-RLYPWE.

The work was performed by the Land and Heritage Conservation Branch (CN-C) of the Installations Division (CN), Construction Engineering Research Laboratory, Engineer Research and Development Center (ERDCCERL). The ERDC-CERL Project Manager was Dr. Susan I. Enscore. At the time of publication, Dr. Christopher M. White was Chief, CEERD-CNC; Dr. J ohn T. Bandy was Chief, CEERD-CN; and Dr. Timothy J . Hayden was the Acting Technical Director for Military Ranges and Lands, CEERDCV-T. The Deputy Director of ERDC-CERL was Dr. Kirankumar Topudurti, and the Director was Dr. Ilker Adiguzel.

This report represents the public release version of a restricted report, ERDC/CERL TR-09-37: "Comprehensive Historical and Architectural Documentation Report for Fort Riley, Kansas." As such, it does not contain an additional appendix, which Fort Riley deemed suitable for release only to the DoD and its contractors.

At the time of publication, The Commander and Executive Director of ERDC was COL Gary E. J ohnston and the Director was Dr. J ames R. Houston. 


\section{Acknowledgments}

This report is a compilation of three separate reports, completed in 19931994, 2007, and 2008. As such, many people were involved in the creation of these studies. For the 1993-1994 report, Historical and Architectural Documentation Reports for Fort Riley, Kansas, acknowledgement is given to the authors. They were Pamela Andros, Dan Lapp, Mira Metzinger, Patrick Nowlan, Carla Spradlin, Steve Turner, and J ulie Webster, all of ERDC-CERL. The Principal Investigators were Keith Landreth and J ulie Webster of ERDC-CERL. The Technical Monitor for the project was Camille Leichliter of the Kansas City District, U.S. Army Corps of Engineers. Vicki Hamilton and Dave J ones at Fort Riley served as the point of contact (POC) for the installation. Real Property Office assistance was provided by Karen Fox.

The 2007 report, Fort Riley Early Cold War Building Inventory and Evaluation, 1953-1960, was authored by Susan Enscore and J ulie Webster, of ERDC-CERL. The following year in 2008, Dr. Enscore and Ms. Webster were joined by Matthew Claus in authoring Fort Riley Building Inventory and Evaluation, 1946- 1952 and 1961- 1963. People who assisted with the development of both reports were Ed Hooker, Department of Public Works and project POC, Fort Riley; Dave Young, Department of Public Works, Fort Riley; William McKale and Bob Smith, Museum Division, Fort Riley; Paula Fultz, Fort Riley Real Property Office; and the librarians at the Dorothy Bramlage Public Library in J unction City, Kansas. Also helpful were the photograph archivists in the Still Pictures room at the National Archives in College Park, MD. 


\section{Unit Conversion Factors}

\begin{tabular}{|l|l|l|}
\hline Multiply & By & To Obtain \\
\hline acres & $4,046.873$ & square meters \\
\hline cubic feet & 0.02831685 & cubic meters \\
\hline cubic inches & 0.00001638706 & cubic meters \\
\hline feet & 0.3048 & meters \\
\hline inches & 0.0254 & meters \\
\hline miles (U.S. statute) & 1.609347 & kilometers \\
\hline square feet & 0.09290304 & square meters \\
\hline square miles & $2,589,998.00$ & square meters \\
\hline yards & 0.9144 & meters \\
\hline
\end{tabular}




\section{Introduction}

\subsection{Background}

Through the years, the U.S. Congress has enacted laws to preserve our national cultural heritage. The first major federal preservation legislation was the Antiquities Act of 1906, instrumental in securing protection for archeological resources on federal property. The benefits derived from the Antiquities Act and subsequent legislation precipitated an expanded and broader need for the preservation of historic cultural resources. With this growing awareness, on 15 October 1966 the U.S. Congress codified the National Historic Preservation Act of 1966 (NHPA), the most sweeping cultural resources legislation to date.

The U.S. Congress created the NHPA to provide guidelines and requirements aimed at preserving tangible elements of our past primarily through the creation of the National Register of Historic Places (NRHP). Sections within this piece of legislation (Sections 110 and 106) require federal agencies to address their cultural resources (defined as any prehistoric or historic district, site, building, structure, or object). Section 110 requires federal agencies to inventory and evaluate their cultural resources. Section 106 requires determination of the effect of federal undertakings on properties deemed eligible or potentially eligible for the NRHP.

In 2007, ERDC-CERL was tasked with consolidating previous architectural inventories and determinations of eligibility (DOE) for Fort Riley buildings covered by studies done in 1993- 1994, 2007, and 2008. Those studies covered facilities constructed from 1855-1945, 1953-1960, and 1946-1952/ 1961-1963, respectively. In addition, the 2008 study inventoried and evaluated 10 facilities missed by earlier efforts.

Fort Riley is located in the northeastern part of Kansas, about 135 miles west of Kansas City and 130 miles north-northeast of Wichita. It consists of six installations including the Main Post, Camp Funston, Marshall Army Airfield (MAA), Camp Whitside, Camp Forsyth, and Custer Hill (Figure 1). The post was originally established in 1853 at the location where the Smoky Hill and Republican rivers join to form the Kansas River, just east and a little north of J unction City, Kansas. 
Fort Riley is home to the U.S. Army 1st Infantry Division (ID), a unit with a distinguished past and present, including being first on the beaches at Normandy in World War II (WWII), and the first division called to fight in the Vietnam War. The 1st ID and Fort Riley, Kansas, provide training and support to ensure soldiers are constantly ready for battlefield deployment.

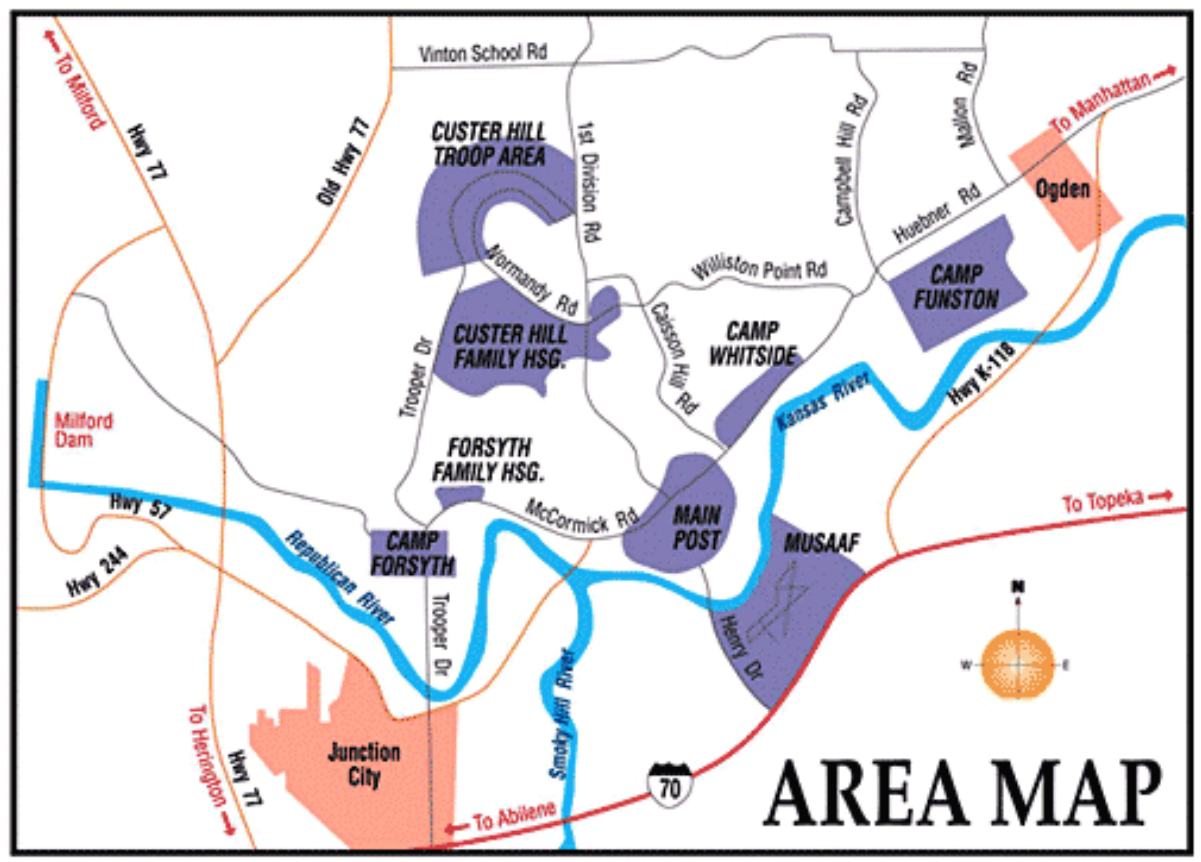

Figure 1. Map of Fort Riley, 2007 (http://www.riley.army.mil/OurPost/Maps.asp.mil).

\subsection{Objective}

The objectives of the three studies were to: (1) inventory all buildings and structures constructed between 1855 and 1963; (2) research the history of those buildings and structures; and (3) assess the eligibility of the buildings and structures according to NRHP guidelines. Inventory and evaluation of these facilities was required for NHPA compliance because they had reached or were close to reaching 50 years of age, and thus were potentially eligible for the NRHP.

\subsection{Approach}

As per Section 110 of the NHPA, Fort Riley needs to evaluate all of its buildings and structures potentially eligible for the NRHP. Under Military Interdepartmental Purchase Requests (MIPRs), the Engineer Research and Development Center's Construction Engineering Research Laboratory (ERDC-CERL) was retained to undertake the three projects by completing inventories and DOEs for the Fort Riley properties. ERDC-CERL was also 
tasked to re-visit the buildings and structures determined eligible in the 1993-1994 report to verify their integrity, and to compile the three building inventory reports into this current report. ${ }^{1}$

This integrated report has several parts. The introduction contains the methodology used for the reports; the next section consists of the combined historic contexts for evaluating the properties, followed by a third chapter containing architectural information on some significant properties. The fourth section presents the combined inventory and evaluation results, and the fifth contains recommendations for the eligible buildings and structures. Appendices are used to present more detailed information such as tables of inventoried and eligible properties.

For a property to qualify for the NRHP, it must: (1) meet at least one of the National Register Criteria for Evaluation, (2) be significantly associated with an important historic context, and (3) retain sufficient integrity to convey its significance under that context. (See Appendix A for complete qualification criteria.)

Several steps are involved to complete the process for determining eligibility to the NRHP, and the same process was utilized during all three projects. The initial two steps, architectural inventory and archival research, are often done simultaneously during the fieldwork period - architectural inventory and archival research. For the 1993-1994 report, ERDC-CERL personnel conducted fieldwork from May- October 1992. For the 2007 project, Fort Riley fieldwork occurred 1-6 April 2007. Fieldwork for the 2008 project was conducted 5-9 November 2007, 31 March- 5 April 2008, and 27 April- 1 May 2008.

\subsubsection{Architectural inventory}

The historic architect prepared a list from information provided by the Fort Riley point of contact (POC) and the Department of Public Works (DPW) office for buildings and structures to be surveyed. Both field notes and digital photographs were taken to provide the data necessary to describe each building.

\footnotetext{
1 The individual building forms are not included in the integrated report.
} 


\subsubsection{Archival research}

Archival research involves several tasks. The first task is the initial literature review. The second is to identify and locate primary research materials.

\subsubsection{Initial literature review}

The project team reviewed published material to determine the general history of Fort Riley for the time period under study and any government agreements affecting military historical preservation. The material included government reports, and books and newspaper articles from the Fort Riley vicinity found at area libraries and museums.

Beginning in the late 1980s and picking up steam in the early years of this present decade, the Department of Defense (DoD) has sought a more costeffective means to inventory and evaluate potentially historic buildings on military installations. Recognizing that many building types are repeated in great numbers across many installations, the DoD, along with the ACHP and the National Conference of State Historic Preservation Officers (NCSHPO), created a series of agreements that allow the military to meet its NHPA obligations for entire classes of buildings at once in a nationwide manner. These agreements are in the form of Programmatic Agreements (PA), Programmatic Memoranda of Agreement (PMOA), and Program Comments, and offer an alternative to the case-by-case approach to inventory and evaluation. At Fort Riley, a PA and three Program Comments were found to apply, and they affect certain buildings constructed at the installation between 1939 and 1974.

In a Congressional report on the Military Construction Authorization Bill for 1983, the DoD was directed to demolish World War II (1939-1946) temporary buildings. ${ }^{2}$ Subsequently, a 1986 PA between the DoD, the ACHP, and the NCSHPO outlines procedures for fulfilling NHPA Section 106 requirements by mitigating the adverse impact of this demolition. $\mathrm{Be}-$ cause of this mitigation (documentation of selected buildings and creation of a historic context study), all remaining WWII temporary buildings con-

2 "Programmatic Agreement between the Department of Defense, the Advisory Council on Historic Preservation, and the National Conference of State Historic Preservation Officers," Available at http://www.achp.gov/progalt/DoD\%20UPH\%20program\%20comment.pdf 
structed between 1939 and 1946 at Fort Riley have met NHPA eligibility requirements and were not included in this inventory and evaluation. ${ }^{3}$

Additionally, the "Program Comment for Cold War Era Unaccompanied Personnel Housing (1946-1974)" was signed 18 August 2006. This Program Comment is a DoD-wide agreement that declares all buildings and structures designed and built as unaccompanied personnel housing (UPH) between 1946 and 1974 to be eligible to the NRHP. 4 The Program Comment covers all ongoing operations, maintenance and repair, rehabilitation, renovation, mothballing, cessation of maintenance, new construction, demolition, deconstruction and salvage, remediation activities, and transfer, sale, lease, and closure of such facilities constructed between 1946 and 1974. A historic context study for Army UPH has been completed as mitigation. ${ }^{5}$ For the Army, this designation applies to all buildings with a current or original category code beginning with 72 and includes barracks, transient lodging, dining facilities, laundry facilities, garages and carports, hutments, tent pads, and bachelor officer quarters. Therefore, at Fort Riley, no evaluation judgment is necessary for these buildings because they are considered eligible to the NRHP for purposes of Section 106 compliance regardless of their level of integrity. In light of this Program Comment, any buildings constructed from 1946- 1963 that fall under its eligibility determinations are excluded from this survey.

Additionally, the "Program Comment for World War II and Cold War Era (1939-1974) Ammunition Storage Facilities" became effective 18 August 2006. ${ }^{6}$ This Program Comment applies DoD-wide to all buildings and structures designed and built between 1939 and 1974 as ammunition storage facilities, and determines them all to be eligible to the NRHP. An existing historic context for these buildings will be expanded to meet mitigation

3 John S. Garner, World War II Temporary Military Buildings: A Brief History of the Architecture and Planning of Cantonments and Training Stations in the United States, (Champaign, IL: U.S. Army Corps of Engineers, Construction Engineering Research Laboratories), 1993.

4 Advisory Council on Historic Preservation, Program Comment for Cold War Era Unaccompanied Personnel Housing (1946-1974), Available at: http://www.achp.gov/progalt/DoD\%20UPH\%20program\%20comment.pdf.

5 Kathryn M. Kuranda, et al., Unaccompanied Personnel Housing (UPH) During the Cold War (19461989), (Frederick, Maryland: R. Christopher Goodwin \& Associates, Inc. for the U.S. Army Environmental Center, Aberdeen Proving Ground, Maryland, 2003).

6 Advisory Council on Historic Preservation, Program Comment for World War II and Cold War Era (19391974) Ammunition Storage Facilities, https://www.denix.osd.mil/denix/Public/Library/NCR/program_alternatives.html?fm-culres (ACHP 2006). 
requirements. ${ }^{7}$ The Program Comment covers all ongoing operations, maintenance and repair, rehabilitation, renovation, mothballing, cessation of maintenance, new construction, demolition, deconstruction and salvage, remediation activities, and transfer, sale, lease, and closure of such facilities constructed between 1939 and 1974.For the Army, this applies to all buildings with a current or original category code beginning with 42 and includes ammunition bunkers, magazines, and igloo storage. For these types of Fort Riley buildings, no evaluation judgment is necessary, because they are considered eligible to the NRHP for purposes of Section 106 compliance regardless of level of integrity. In light of this Program Comment, any buildings constructed from 1946-1963 that fall under its eligibility determinations are excluded from this survey.

More recently, on 31 May 2002, the ACHP approved the "Program Comment for Capehart and Wherry Era Army Family Housing and Associated Structures and Landscape Features (1949-1962)."8 Through this agreement, the Army's entire inventory of Capehart-Wherry housing is eligible to the NRHP for the purposes of Section 106 compliance, and a historic context with accompanying design guidelines has been produced as mitigation. ${ }^{9}$ The Program Comment covers all maintenance and repair actions; rehabilitation; layaway and mothballing; renovation; demolition; demolition and replacement; and transfer, sale, or lease out of federal control for Capehart-Wherry housing, associated structures, and landscape features, as well as all other family housing constructed between 1949 and 1962. This effectively removes the need to inventory and evaluate CapehartWherry housing at Fort Riley, as the buildings are eligible regardless of level of integrity. At Fort Riley, Capehart-Wherry housing includes Rim Rock Terrace in the Main Post (ca. 1950), Colyer Manor at Camp Forsyth (ca. 1950), and Monteith Heights (1962), Warner Heights (1963), and Pe-

7 Joseph Murphey, et al., Army Ammunition and Explosives Storage in the United States, 1775-1945, (Fort Worth: U.S. Army Corps of Engineers Fort Worth District, 2000).

8 Advisory Council on Historic Preservation, Program Comment for Capehart and Wherry Era Army Family Housing and Associated Structures and Landscape Features (1949-1962), (Washington, DC: Federal Register. Vol. 67, No. 110, June 7, 2002), 39332-39335.

9 Kathryn M. Kuranda et al., Housing an Army: The Wherry and Capehart Era Solutions to the Postwar Family Housing Shortage (1949-1962), (Aberdeen Proving Ground, MD; U.S. Army Environmental Center, 2003); R. Christopher Goodwin, and Associates, Neighborhood Design Guidelines for Army Wherry and Capehart Era Family Housing, (Aberdeen Proving Ground, MD; U.S. Army Environmental Center. 2003). 
terson Heights (1963) at Custer Hill. ${ }^{10}$ Because of this Program Comment, these buildings were not included in this effort.

\subsubsection{Primary research material}

The project team then located primary research materials and additional secondary materials to enhance the published sources. This report is based primarily on the collections found at Fort Riley, including the review of cultural resource studies, historical accounts, real property data, construction program documentation, and visual information (photographs, technical illustrations, architectural drawings, maps, charts, etc.). Most resources were provided by the Conservation and Restoration Branch, Environmental Division, Fort Riley. The Fort Riley Museum Division provided textual and photographic resources. The Dorothy Bramlage Public Library in J unction City, Kansas provided access to area newspaper microfilm archives. Visits were made to the National Archives at College Park, Maryland in 2007 and 2008 to locate additional historic photographs and textual information.

\subsubsection{Analysis}

After the initial research was completed, the team analyzed the gathered information. Archival and field information was integrated throughout the course of the research. Using the archival sources, the research team discovered relevant historical information. As the field research identified specific building and structure type characteristics or relationships, the research team refined their questions and looked further in the archival records for answers. The integration of archival and field methods necessitated an integration of visual and written sources in this final report.

The inventory and evaluation projects utilized historic photographs and knowledge of standard plans to inform findings and to provide evidence of the historical characteristics of the structures surveyed. For determining integrity of the buildings, the researchers relied heavily on real property cards and engineering plans (and historic photographs when available) to determine the original conditions. The researchers relied on the information from the real property office and the engineering plans to determine size, areas, and costs of the buildings. Some information on the construc-

\footnotetext{
10 The last two projects were underway in 1962, so they fall under the Program Comment. Construction
} dates given are for project completion. 
tion and development of the buildings and structures under study was located in back issues of the local newspapers and at the National Archives. For purposes of determining eligibility, a period of significance from 1852- 1963 was used. This encompasses the periods of construction for the properties under study. The final chapter provides management recommendations pertaining to the properties that have been determined eligible to the NRHP.

\subsubsection{Products}

In addition to the work of three reports that is consolidated here, the 19931994 project produced documentation for every inventoried property to standards set by the Historic American Buildings Survey (HABS) program through the National Park Service (NPS). HABS has standards for four levels of documentation, depending on the level of detail needed, from Level I (the most in-depth) to Level IV. For broad inventories such as the one at hand, Level IV reports are considered sufficient by HABS, the State Historic Preservation Offices (SHPO), and the DoD. Level IV documentation produced for the 1993-1994 report consisted of a one-page form including architectural, historical, and photographic information, along with 5" x 7" photos and contact prints of the exterior. The HABS Level IV reports were produced by the use of the Integrated Building Inventory System (IBIS), a database/ report generation system developed at CERL. IBIS data could be imported to the Cultural Resources Information System (CRIS) database, allowing the installation's cultural resource manager to efficiently search and retrieve data on the buildings documented.

For the 2007 and 2008 inventories and evaluations, the individual buildings and structures were documented in a database created by historical architect J ulie Webster. Each property has a multi-page form containing architectural and historical information along with a condition assessment and digital photographs of the exterior. The forms were combined into a portable document file (pdf) format that was made available to the sponsor.

\subsection{Scope}

As this report is a compilation of three separate studies, there are some inconsistencies in levels of detail. The original report (1993-1994) covered 
all buildings and structures constructed from 1855-194511. Such a vast time period meant that the historic context was fairly broad and did not always provide a high level of detail concerning activities on post. Also, the large time span included several hundred buildings to inventory and evaluate, so there is a lack of detail concerning the construction of certain specific buildings. The building inventory from the 1993-1994 report is included in this current compilation in order for the first time to assemble a complete historic continuity for Fort Riley. The 2007 and 2008 reports cover much smaller periods of time, and therefore were conducted at a much finer level of detail.

11 Even though Fort Riley's history predates 1855, there were no permanent structures built prior to that date, and none of the earlier temporary structures have survived. 


\section{The Historic Context for Fort Riley Development, 1852 - 1963}

In order to fully understand how these buildings fit into the broad patterns of our cultural heritage, we must place these buildings into their proper historic context. The following section is an overview of the evolution of Fort Riley and traces the history of the installation from its beginning as a new outpost established to protect westward traveling traders and settlers, to its present day status as the home of the 1st Infantry Division. This historical overview was used to create the thematic groups within the historic districts and to determine which buildings fit into those groups.

The building numbers used in the following historical overview refer to the new numbers assigned to each building in October 1987 by the Fort Riley Real Property Office. When individual buildings are referenced, both the post-1987 and pre-1987 numbers are given, in that order. For instance, if Building 87 is referenced, it will appear as Building 87/ 170.

Fort Riley is in the northeastern part of Kansas (about 135 miles east of Kansas City and 130 miles north-northeast of Wichita). It was established in 1852 at the site where the Smoky Hill and Republican Rivers join to form the Kansas River, just east and a little north of J unction City. Fort Riley today consists of six cantonments which are the Main Post, Camp Funston, Marshall Army Airfield, Camp Whitside, Camp Forsyth and Custer Hill. The historic areas of the fort are located along the lowlands and floodplain of the two rivers, while modern housing and training areas are found on land north of the original post.

The Louisiana Purchase of 1803, the first territorial acquisition made by the United States, added some 828,000 square miles of land between the Mississippi River and the Rocky Mountains. During the ensuing fifty years, as trade and transportation routes were established, settlers and traders began moving west, displacing the Native American Indians in the process. In what is now Kansas, trade and travel began to develop along several trails including the Santa Fe Trail, the Oregon Trail, and the Smoky Hill Trail. Consequently, forts were established near the trails in order to provide protection to settlers moving westward. Fort Riley was one such frontier post. 


\subsection{Establishment of Fort Riley}

In the winter of 1824-25, Congress passed a bill authorizing the marking of the Santa Fe Trail from Missouri to New Mexico. Fearing that Native Americans living on the plains would interfere with commerce over this trail, Congress appointed a commission to negotiate with them in an attempt to gain consent to the survey and marking of the trail. As a result, a treaty was signed with three tribes (the Great Osage Indians, the Little Osage Indians, and the Kansas [aka Kansa] Indians) at Council Grove on 11 August 1825. In exchange for the equivalent of $\$ 500$, the Indians agreed to allow surveying and marking of the trail. They also agreed not to molest travelers using the trail. The survey was completed in 1827.12

Despite the 1825 treaty, there were many conflicts between the natives and traders along the trail. Eventually the altercations became enough of a problem that traders asked the government for protection. Until that time, the westernmost outpost was Fort Leavenworth, Kansas, which was established in May 1827 to protect the developing trade along the Santa Fe Trail (opened in 1821). Located on the Kansas-Missouri border, north of Kansas City, Fort Leavenworth grew increasingly important as a supply and training base. However, with the continuing westward expansion, this outpost became too far removed from the location of raids and disputes that needed immediate attention. In the early 1850s, the U.S. Army realized that a fort located farther west was needed to better protect traders and settlers moving along the Santa Fe and Oregon Trails.

In J uly 1852, the commanding officer of Fort Leavenworth, Colonel T.T. Fauntleroy, recommended that a post be established "at or near a point on the Kansas River where the Republican fork unites with it." 13 In September of the same year, General N.S. Clarke of the Sixth Military Department appointed a board of officers to select the location for the new post somewhere near the forks of the Kansas River. The board included Captains E.A. Ogden and L.C. Easton of the Quartermaster's Department; Captain C.S. Lovell, Sixth Infantry; and Lieutenant J .C. Woodruff, of the Topographical Engineers.

12 W.F. Pride, The History Of Fort Riley (U.S. Cavalry Museum and Fort Riley Historical and Archeology Society, 1926), 41.

13 Ibid., 60-61. 
These men traveled to and chose the present site of Fort Riley. Believing they were near the geographical center of the United States, they initially named the new post Camp Center. Camp Center was strategically located at the junction of the Republican and Smokey Hill Rivers with the Kansas River. It would provide protection for users of the Santa Fe Trail to the south of the fort, the Smoky Hill Trail east of the fort, and the Oregon Trail north of the fort. ${ }^{14}$ The board submitted its report in November of 1852.

It seems likely that the board also submitted with its report a proposed plan of the fort. Reference to an approved plan is found in official correspondence less than two years later, and the officer's professional backgrounds would have well qualified them to prepare a plan at the time of their visit. Probably Captain Lovell and Lieutenant Woodruff selected the exact site of the post's parade, while Captain Ogden and Captain Easton advised on the siting and number of buildings. ${ }^{15}$ The board's report was approved by the Secretary of War in J anuary 1853. ${ }^{16}$

In May 1853, Captain Charles S. Lovell arrived at Camp Center bringing with him Companies B, F, and H of the Sixth Infantry. Congress appropriated $\$ 65,000$ for the erection of buildings, presumably temporary, which the men of the Sixth Infantry occupied that year. These early buildings were constructed partly of native timber and partly of material brought overland or up the river from Fort Leavenworth. There are no pictorial records of these structures and none of them remain today ${ }^{17}$.

In J une 1853, the name of the post was officially changed to Fort Riley in honor of the recently deceased Major General Bennett Riley. ${ }^{18}$ Bennett Riley earned distinction as an able cavalryman under Lt. Colonel Henry Leavenworth. As a major, Riley commanded the first wagon train escort over the Santa Fe Trail in 1829. During his participation in the Mexican War, Riley was promoted to brigadier general and then later to major general for distinguished service. Later in life, Riley became the last territorial

\footnotetext{
14 Robinson \& Associates, Fort Riley: An Historic Overview, V.I., Report prepared for U.S. Army Corps of Engineers, Kansas City District,(Washington, D.C., October 1989), 11.

15 Catherine Crawford, "Historical Information: The Planning of Fort Riley, 1852-1939" in Fort Riley Family Quarters Documentation Project, HABS No. KS-54, (National Park Service, September, 1985), 2.

16 lbid., 61.

17 Thus, the period covered for buildings at Fort Riley does not date to 1853 , but rather to the first permanent structures, built in 1855 (see Section 2.2).

18 Pride, The History Of Fort Riley, 61.
} 
governor of California (in 1847) and helped write that state's constitution. He died in Buffalo, New York in 1853.19

\subsection{Early construction}

In March 1855, Congress made an additional appropriation for Fort Riley for the construction of permanent buildings sufficient for ten companies of cavalry and ten companies of infantry. Building activity began in J uly of that year under the direction of Major Ogden (who had also supervised construction of the temporary structures).

As this construction was getting under way, however, a cholera epidemic broke out and claimed the lives of close to 100 workers and also Major Ogden. Panic and disorder resulted, and men began deserting the fort. Sgt. Lowe and J oseph O. Sawyer, a civilian engineer, restored order, took command of the post, and organized burial parties. A few days later, Lt. Eugene Carr, accompanied by a doctor, arrived from Fort Leavenworth to assume command. By the middle of August, the epidemic subsided. By early September, the post was back to normal and construction work was resumed. ${ }^{20}$

As 1855 came to a close, twelve major buildings and several auxiliary structures had been completed. The post was beginning to resemble the 1852- 53 plan. The nucleus of the installation was formed by the construction of officer's quarters and barracks around a 553' by 603' rectangle parade ground located on a high, relatively level area north of the Kansas River. The arrangement included six barracks for enlisted men along the east and west sides of the parade ground. Six sets of officer's quarters were situated along the north and south sides.

A hospital was constructed east of the parade ground while a guard house, a sutler's store, and carpenter, saddler, and blacksmith shops were built directly to the west. Five stables, an ice house, and a commissary storehouse were erected to the southwest, while a brick magazine was built to the northwest. For some reason, the chapel and parsonage were built some distance to the northwest of the parade group.

\footnotetext{
19 Fort Riley: Its Historic Past, (U.S. Government Printing Office, 1981), 16, 565-238/115 Region No.6.

20 "Frontier Post Is Designated As Fort Riley June 27, 1853," Junction City Union, 24 June 1953.
} 
Native limestone was used to construct the first permanent buildings and subsequent buildings at Fort Riley. The woodwork for the early buildings at Fort Riley was made at a factory in Cincinnati and shipped by boat to Fort Leavenworth along with the necessary lumber, hardware, and glass. After being loaded onto wagons at Fort Leavenworth, the material was transported to Fort Riley.

\subsection{Early limestone construction at Fort Riley}

Limestone is found in abundance in the high river bluffs that border the three rivers dividing the J unction City- Fort Riley area. The Fort Riley Military Reservation includes several limestone quarry sites which provided the stone used in the construction of buildings. The quarries are at Grant Cliffs and Sheridan Bluffs along the Kansas River, at Sherman Heights along the Republican River, and along both sides of the Smoky Hill River. ${ }^{21}$ The first quarry at Fort Riley was located at the present site of the Ogden Monument (east of the main post along Huebner Road). A marker on the monument reads:

On this site marked by this monument, Major Ogden, in 1855 opened a quarry from which was obtained stone used in the construction of the first permanent buildings at Fort Riley.

The early stone structures at Fort Riley were constructed of hammered, ashlar block limestone, built of a simple, unornamented, vernacular architectural style. Each stone had to be hand cut and dressed using the simple cutting tools, hammers, chisels, etc., of the day. The walls of the early stone buildings at Fort Riley are thick, approximately sixteen to eighteen inches. ${ }^{22}$

\subsection{Contractors and workers}

Major E.A. Ogden, the post's first quartermaster, realized that stone construction was necessary, due to lack of timber in the region. This meant hiring special workers who were familiar with stone construction. In an 1855 letter written to the Quartermaster General in Washington, D.C., Ogden reported that he had hired 100 masons and sixteen stone cutters, along with thirty carpenters and teamsters, and four blacksmiths. Hiring

\footnotetext{
21 Crawford, "The Planning of Fort Riley," 9.
}

22 Ibid., 13. 
stone workers was fairly expensive because they received around $\$ 2.00$ to $\$ 2.50$ per day as opposed to the carpenters, painters, plasterers, and blacksmiths whose daily pay ranged 50 cents to $\$ 1.00$ less. $^{23}$

Stone masons often were recent immigrants from Ireland and Germany, where stone buildings were constructed much more extensively than in America. By 1853, Fort Riley building activity had attracted Irish and German immigrants from Cincinnati and St. Louis. The workers arrived at Fort Riley in March 1855, after soldiers left for summer campaigns. They slept in barracks or tents. These stone masons and carpenters built smooth-faced limestone buildings at the post under the supervision of J oseph O. Sawyer (employed as an "architect and supervisor"). ${ }^{24}$

\subsection{Remaining buildings from initial construction period}

The only structures remaining from the initial period of permanent construction at Fort Riley (mid 1850s) include St. Mary's chapel (Building $3 / 3$ ), Building 24/24, the parsonage (Building 123/ 123), and the old hospital (Building 205/30).

St. Mary's Chapel, whose cornerstone was laid by J .E.B. Stuart in 1855, underwent major renovations in 1896 and again in the late 1930s. Although extensively modified, the basic, classic lines of the 1855 chapel can still be seen both inside and out. ${ }^{25}$ Building 24 , the only remaining set of the original six officers quarters built at Fort Riley in 1855, is now the Custer House. Then Lt. Colonel George A. Custer and his wife were stationed at Fort Riley from November 3, 1866 to J uly 26, 1867. It is known that the Custers did not live in Building 24/ 24 but lived in that building's sister set of quarters, Building 21/21. However, Building 21/21, originally built in 1858, was severely damaged in a fire in the 1930s and has been completely reconstructed.

Building 123/ 123, built in 1855, was originally occupied by Chaplain David Clarkson who lived there from 1855- 1861. Clarkson, the first to give regular services at Fort Riley, was largely responsible for initiating the construction of St. Mary's Chapel. A rear section was added to the original,

\footnotetext{
23 Crawford, "The Planning of Fort Riley," 10.

24 Ibid., 11.

25 Richard Scott Price, Encounter With Historic Sites: Saint Mary's Chapel (Class paper, California State University, 1992).
} 
back kitchen wing of the building in 1890; it has since undergone many other alterations.

Building 205/30, originally constructed in 1855, was rebuilt in 1890 as a cavalry administration building and is now the U.S. Army Cavalry Museum.

\subsection{Civil War years and the 1860s}

Activities at Fort Riley in the late 1850's were overshadowed by ominous events in other parts of the country. Torn over issues such as slavery and state's rights, the country plunged into a civil war. During the Civil War years (1861-65), construction at Fort Riley was put on hold. Since the troops garrisoned at Fort Riley were from all over the country, the men's sympathies were divided when war broke out. Some officers enlisted with Union troops while others, including J.E.B. Stuart, enlisted with the Confederacy forces. During the war, soldiers of the Regular Army were transferred back East, leaving mainly volunteer troops garrisoned at Fort Riley. Owing to the lack of use, Fort Riley fell into disrepair.

Then, after the Civil War ended, two important events had a significant impact on Fort Riley: (1) The Union Pacific Railroad reached Ogden, J unction City, and Fort Riley; and (2) the 7th Cavalry Regiment was constituted at Fort Riley.

During the construction of the railroad, serious Indian uprisings had developed. As a result, the 7th Cavalry Regiment (under the command of Col. Andrew J . Smith and then Lt. Col. George Armstrong Custer) was organized by an Act of Congress in 1866 and stationed at Fort Riley to protect settlers and railroad workers. This famous regiment participated in many important battles during the Great Indian Wars of 1867-68, most notably the Battle of Little Big Horn which took place in Montana on 25J une 1876. During this famous battle, five troops of the 7th Cavalry were destroyed. General George Custer and his brothers, Tom and Boston, plus 212 men and officers were among those who died. ${ }^{26}$

During the Civil War and afterward, hunters, travelers and settlers increasingly began to encroach on traditional buffalo hunting grounds of the Native American Indians. They reacted by conducting raids which contin-

26 Fort Riley: Its Historic Past, 19. 
ued into the 1870s in a losing effort to retain their homelands. In the late 1860s, General Phillip Sheridan, head of the Military Division of the Missouri, had been ordered by military chiefs in the nation's capital to pursue a policy of total war against the plains Indians with the intent of forcing them to stay on their reservations. ${ }^{27}$ In conjunction with this policy, Fort Riley in the mid 1860s was occupied by many different organizations for short periods of time. These organizations conducted frequent forays against hostile Native Americans and other marauders. ${ }^{28}$

Very little construction took place at Fort Riley during the 1860s, and the fort retained its mid-1850s appearance (Figure 2). Besides a few repairs and minor renovations to existing structures, the only building activity during this time involved the reconstruction of the Ogden Monument and the building of a set of laundresses' quarters (which no longer exist).

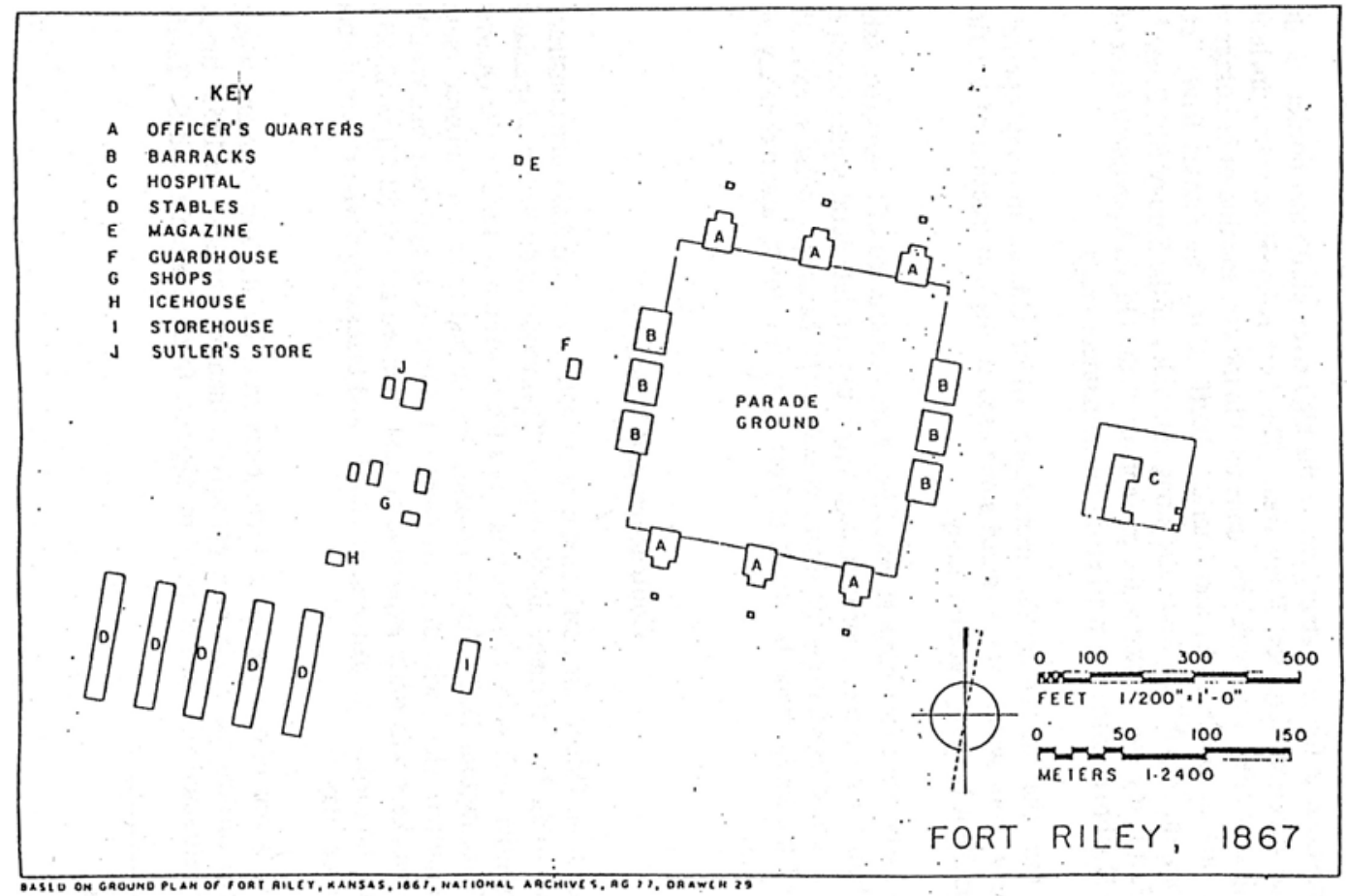

Figure 2. 1867 Plan of Fort Riley (prepared by ERDC-CERL, based on NARA original).

As the Native Americans were pushed farther north and west, Fort Riley became less useful as a center for military operations. ${ }^{29}$ Like Fort Leaven-

\footnotetext{
27 Kansas Preservation Plan: Study Unit on the Period of Exploration and Settlement (1820s-1880s). (Topeka, Kansas: Historic Preservation Department, Kansas State Historical Society, 1987), 23. 28 Pride, The History Of Fort Riley, 162.

29 Mariani \& Associates Architects, Study/Survey of Historically Significant Army Family Housing Quarters, V.I, (Installation Report, Fort Riley, Kansas, June, 1988), 16.
} 
worth before it, the fort became too far removed from troubled areas. It was therefore maintained by only a small garrison for the latter part of the 1860s and was in danger of being abandoned completely. This changed in 1869 when Fort Riley was chosen to become the location for a school of Application for Light Artillery. This development brought more men to the post; however, no permanent buildings were constructed in conjunction with the school which, as it turned out, proved to be short-lived. In 1871, the school was discontinued and most of the trainees were dispatched to deal with various Indian uprisings throughout the west. Following the closure of the school, Fort Riley was almost abandoned. Only one company of the 6th Cavalry remained, consisting of four officers and sixty-five enlisted men. ${ }^{30}$

By the mid-1870s, the Native Americans in Kansas had been subdued and placed on reservations and the state was becoming settled. As a result, General Sheridan urged the closing of most Army posts in Kansas. The only two forts not abandoned were Fort Riley and Fort Leavenworth. During the next few years however, Fort Riley remained minimally occupied and its future remained in doubt. 31

The threat of closure of Fort Riley was effectively extinguished in 1884, when General Sheridan recommended that the headquarters of the U.S. Cavalry be located at Fort Riley. Authorization was secured in 1885 and funds were made available for repairing and expanding the fort. That same year, recommendations were made that an Army field artillery school be established. Brigadier and Inspector General Nelson H. Davis also suggested in 1885 that a cavalry school should be established. He wanted the school to include instruction in drill, practice firing, stable management, and horse training. Citizens of the towns located near Fort Riley were enthusiastic about expanding the fort for this purpose, knowing that such a development would help their local economy. When General Sheridan visited Fort Riley in May of 1885, the mayor of J unction City and a crowd turned out to greet him to show their support.

In August of 1885, Brigadier-General Nelson A. Miles, Commanding Officer of the Department of the Missouri, and Major J ames Gillis, Chief Quartermaster of the Department, visited Fort Riley to decide upon a plan

30 Pride, The History Of Fort Riley, 166.

${ }^{31}$ Robinson \& Associates, Fort Riley: An Historic Overview, 13. 
for the improvement of the post and the location of new buildings. The influence these two men had on the design of the plan that was later adopted for Fort Riley is unknown. It is possible that they were partly responsible for the eventual decision to construct separate posts for cavalry and artillery at Fort Riley.

In the middle of September of 1885, Captain George E. Pond arrived at Fort Riley and assumed the duty of Post Quartermaster. He was to oversee the construction of new buildings and the repairs to existing ones. Captain Pond was a graduate of West Point (Class of 1872) and served in the Army for 40 years until he retired in 1907. After his graduation from West Point, he served with the 8th Cavalry until he was transferred to the Quartermaster Corps in 1883. Pond served at Fort Riley until 1891, officially becoming the Constructing Quartermaster in 1887 when that job was separated from the Post Quartermaster's other duties. ${ }^{32}$ After arriving at Fort Riley, Pond immediately initiated construction of two new barracks (Buildings 215/ 35 and 221/39) and an officer's quarters (Building 23/23). By October, work on these structures as well as repairs to some older buildings was under way. ${ }^{33}$

In J anuary of 1886, as expansion and repairs at Fort Riley were progressing, both houses of the Kansas Legislature passed resolutions recommending the further enlargement of Fort Riley with the intention of "establishing at said post a school for the training of the cavalry and light artillery arms of the service." 34 In J anuary 1887, the United States Congress officially authorized a school for cavalry and light artillery at Fort Riley and initially appropriated $\$ 200,000$ for construction of facilities. Establishment of the cavalry and light artillery school at Fort Riley spurred the greatest era of construction and expansion at the installation.

\subsection{Construction of the cavalry and artillery posts}

In early April of 1887, General Sheridan visited Fort Riley and met with Major Edward B. Williston. Together they settled on a definite location for the artillery post. Work was to begin when the funds were made available.

\footnotetext{
32 Mariani \& Associates, Study/Survey of Historically Significant Army Family Housing Quarters, 18.

33 Pride, The History Of Fort Riley, 195.

34 Ibid.
} 
Major Williston was placed in charge of the work, under the general supervision of Captain Pond. 35

Captain Pond, who had begun working on a new plan for Fort Riley after he arrived, designed two separate but adjoining posts, thereby abandoning the original 1855 post plan (Figure 3). The two posts, while preserving separate identities owing to the differences in cavalry and artillery training, would share in the educational mission of the entire post. 36

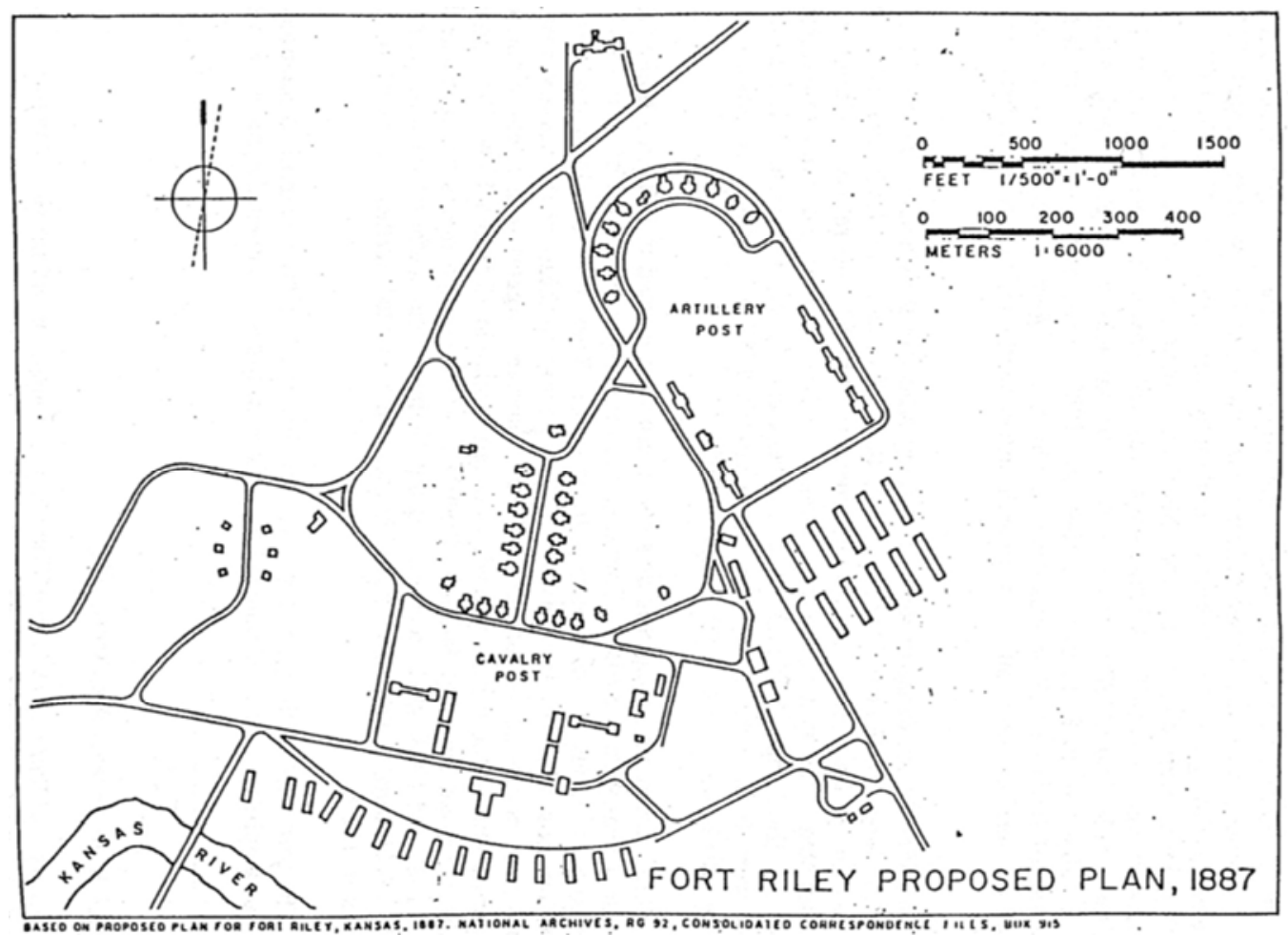

Figure 3. Cavalry and Artillery Posts Plan for Fort Riley (largely implemented), 1887 (CERL - based on NARA original).

The cavalry post featured a bi-axial plan with the east-west parade ground forming one axis and Forsyth Avenue forming the other. ${ }^{37}$ The existing cavalry parade ground of the old plan of the fort was expanded along its east and west sides to become the Cavalry Parade Field. This was accomplished by demolishing the 1850s barracks that lined the old parade ground. The northern boundary of the old parade ground was retained. 38

\footnotetext{
35 Ibid.

36 Crawford, "The Planning of Fort Riley," 5.

37 Crawford, "The Planning of Fort Riley," 5.

38 Mariani \& Associates, Study/Survey of Historically Significant Army Family Housing Quarters, 19.
} 
Buildings 21/ 21 and 24/24, located directly north of the Cavalry Parade Field along Sheridan Avenue, were the only two officer's quarters remaining from the original 1855 plan of the post. Building 23/ 23 was constructed directly east of Building 24/ 24 in 1886. More officer's quarters were constructed along Sheridan Avenue just north of the Cavalry Parade Field between 1887 and 1889. A guard house was built in 1889 next to the post hospital on the east side of the parade field. Two sets of cavalry barracks were erected on the south side of the Cavalry Parade Field between 1886 and 1889 (Figure 4). (The set of barracks built at the present site of Building 211/34, was destroyed by fire in March 1945). Cavalry stables, arranged in a semi-circular pattern, were built farther south of these structures between 1889 and 1904 (Figure 5).

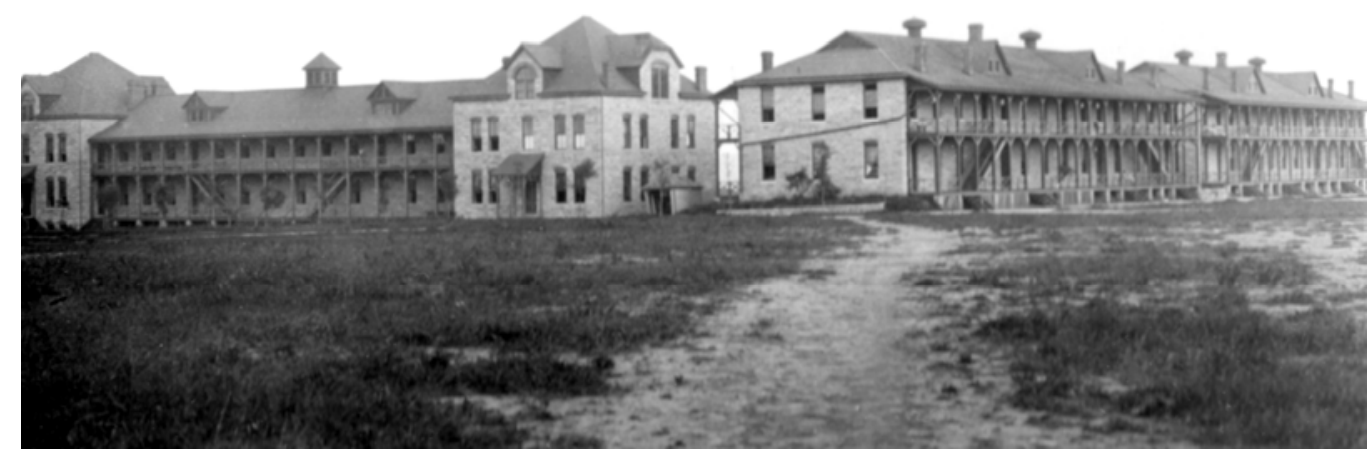

Figure 4. Cavalry barracks in undated view (NARA).

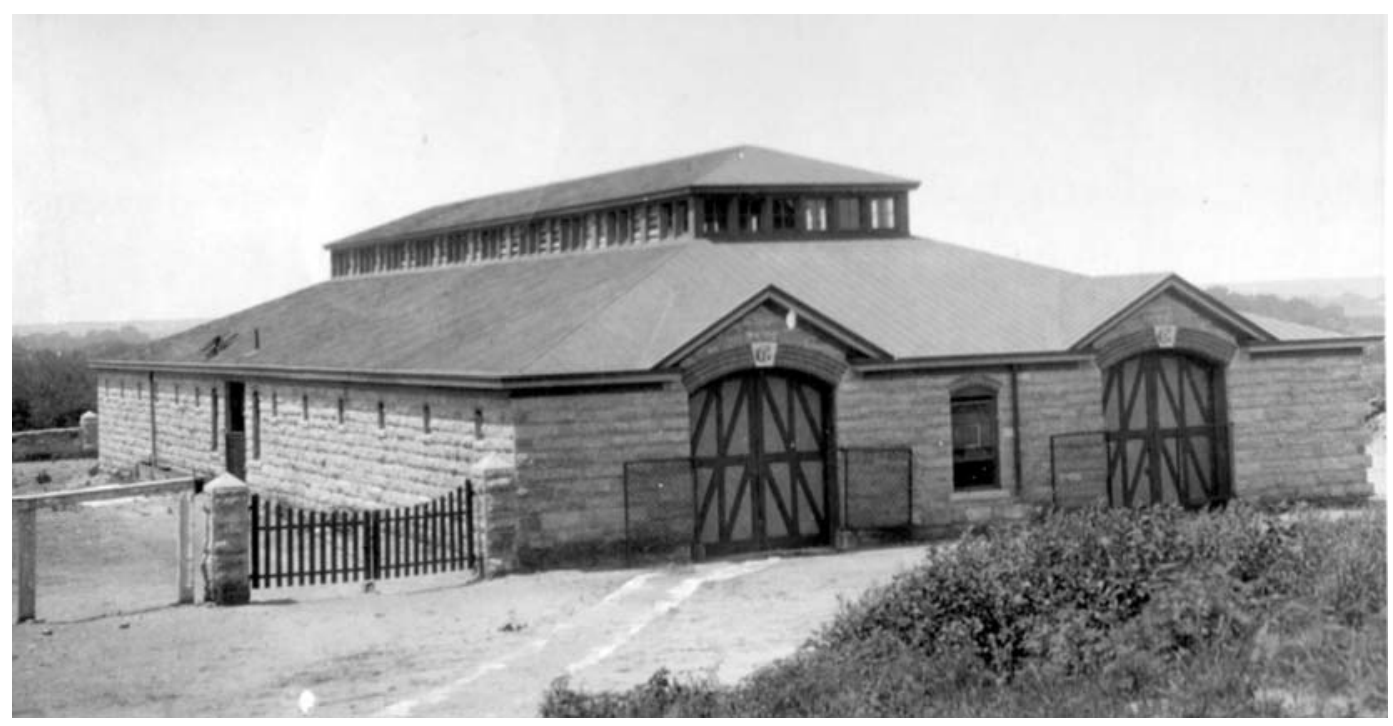

Figure 5. Cavalry stable in undated view (NARA). 
In 1888, the Cavalry's commanding officer's residence (Building $1 / 1$ ) was built at the head of Forsyth Avenue along Barry Avenue (Figure 6). In 1889 and 1890, three residences for the field officers next in command were built (Figure 7). One residence (Building 2/2) was constructed to the west side of the commander's house at the top of Forsyth Avenue and the other two (Buildings 19/ 19 and 26/26) at either end of Sheridan Avenue. 39 Eleven officer quarters were built along Forsyth Avenue between 1887 and 1894. Another quarters (Building 18/ 18) was added to this group in 1903.

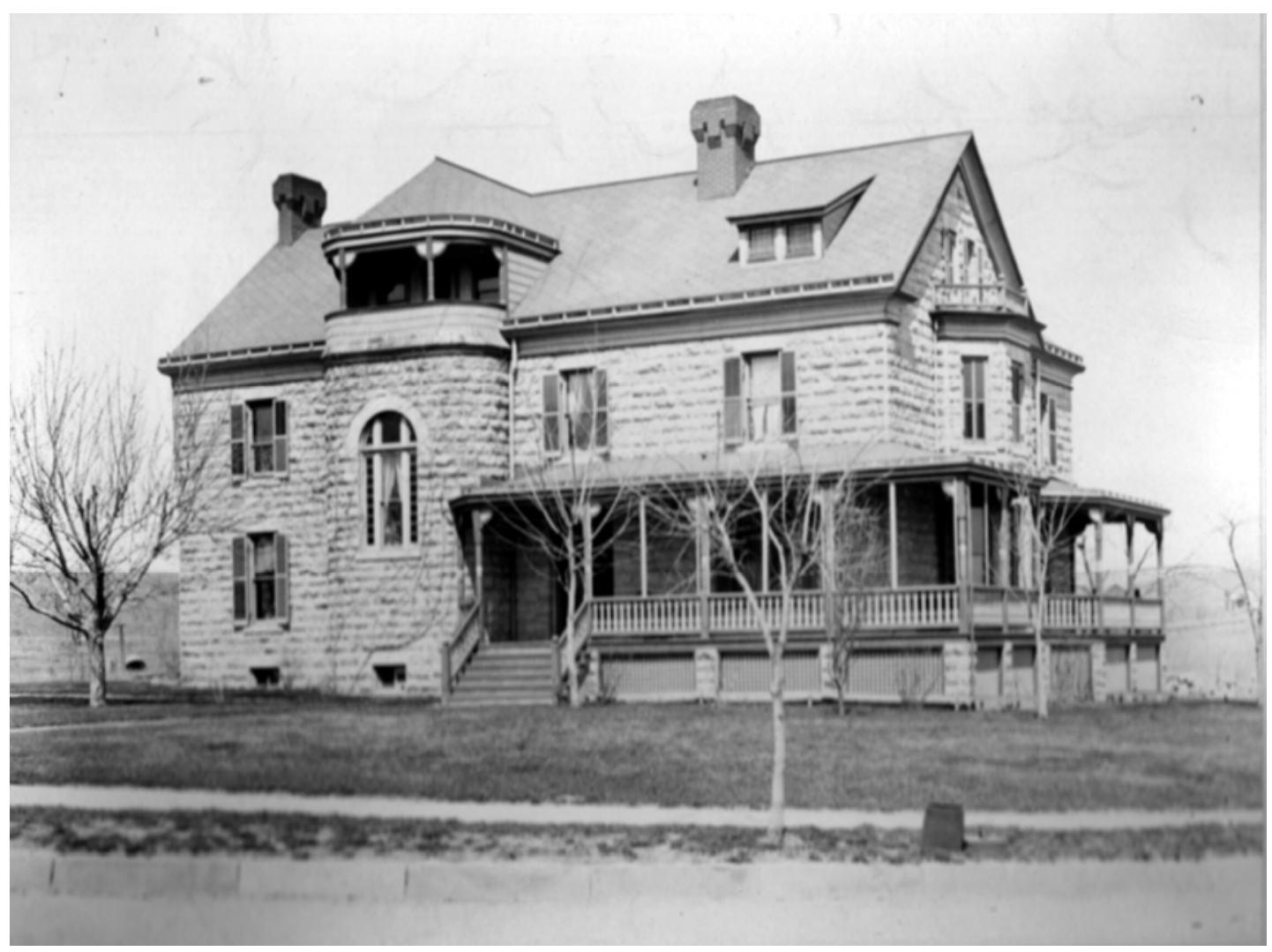

Figure 6. Commandant's Quarters, BIdg 1, circa 1900 (NARA).

39 Anonymous. "The Growth and Building History of Fort Riley," anonymous manuscript on file at Kansas State Historical Society, Topeka, Kansas. 


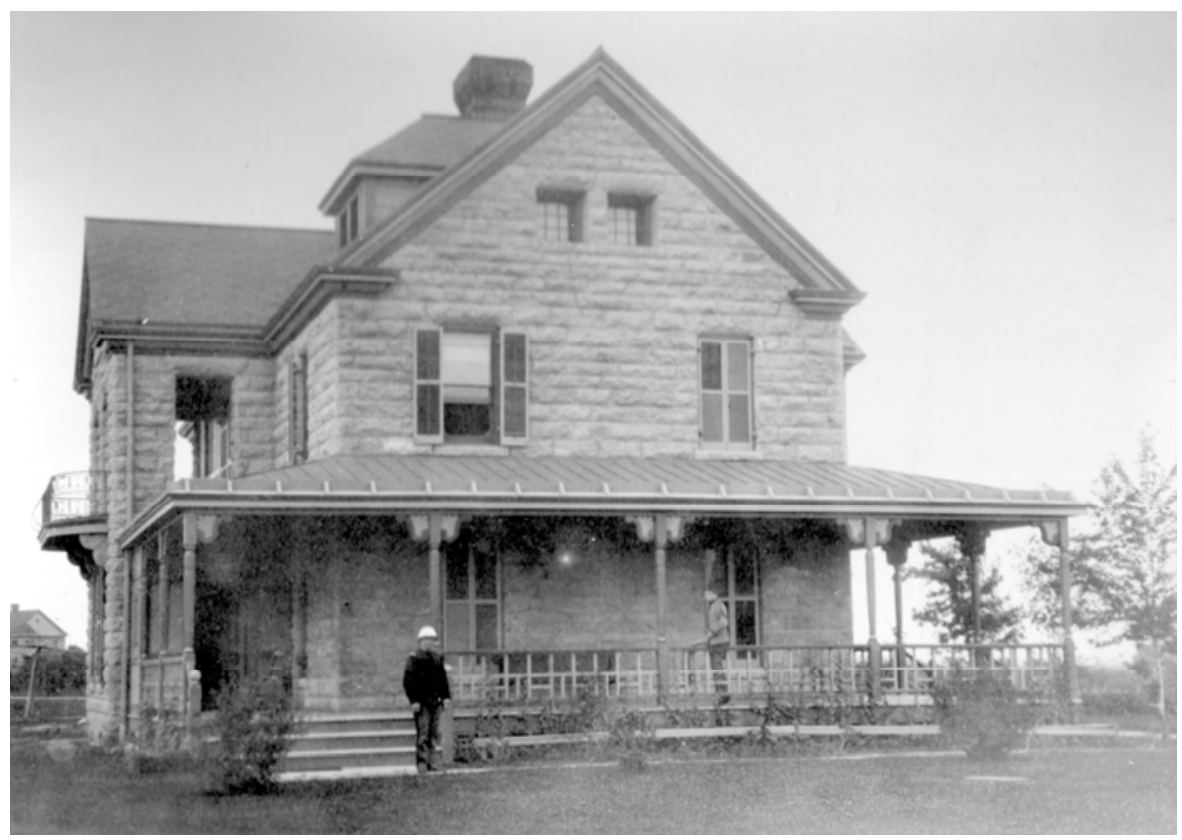

Figure 7. Field Officers' housing at Fort Riley, circa 1900 (NARA).

Three structures arranged in an arch pattern were erected in 1889 in a hollow to the west of the Cavalry Parade Field. This area was for noncommissioned officers (NCO). Additional NCO quarters were planned for this area. They were to be built at a later date (Figure 8).

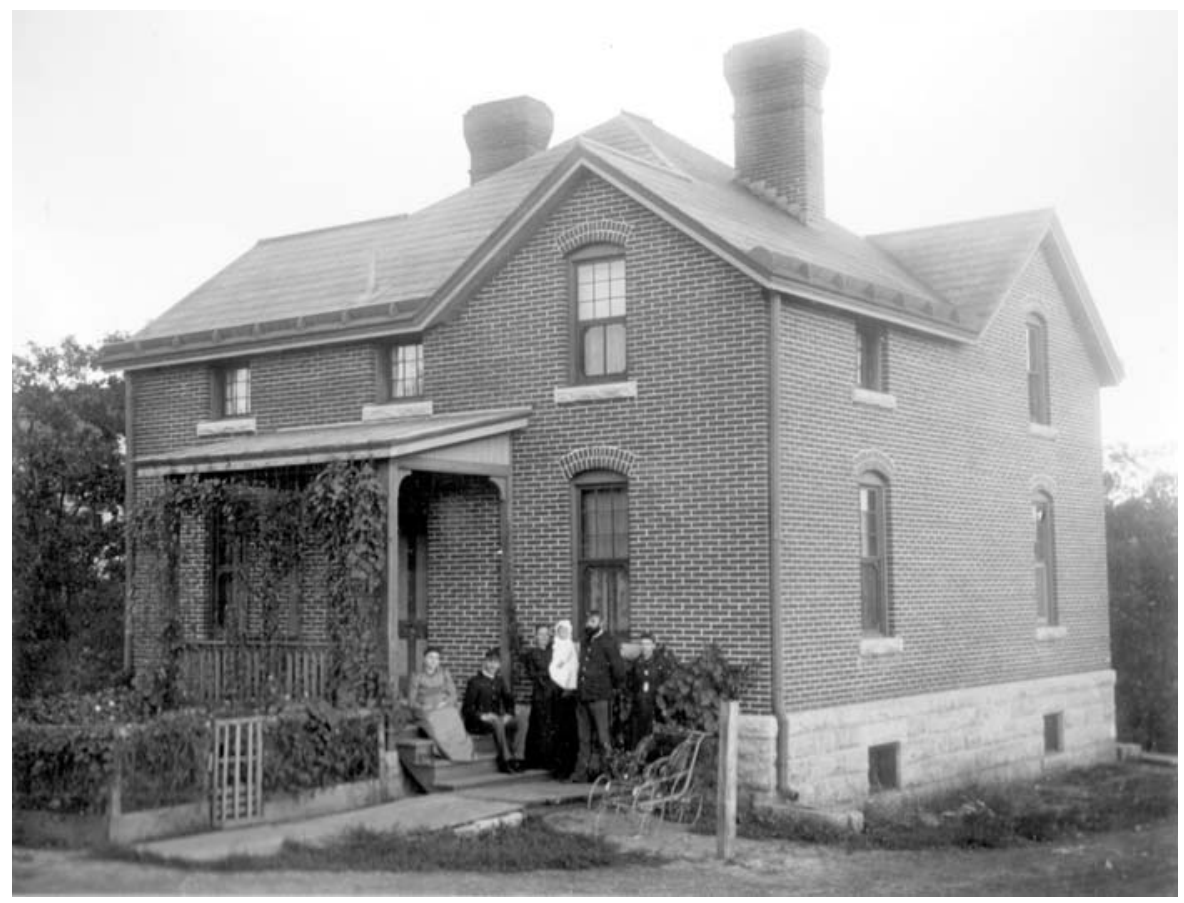

Figure 8. NCO quarters, circa 1900 (NARA). 
The artillery post was set around its own parade ground northeast of the cavalry post. The parade ground axis runs from northwest to southeast. Officer's quarters, organized in a semi-circle along the upper section of the parade ground, were built between 1887 and 1909 . The artillery post administration building (Building 403/92) and five enlisted men's barracks, all built 1889-1903, were erected along the southwest and southeast sides of the parade ground (Figure 9). Additional stables and guard houses were erected in 1889 farther southeast of these structures. 40

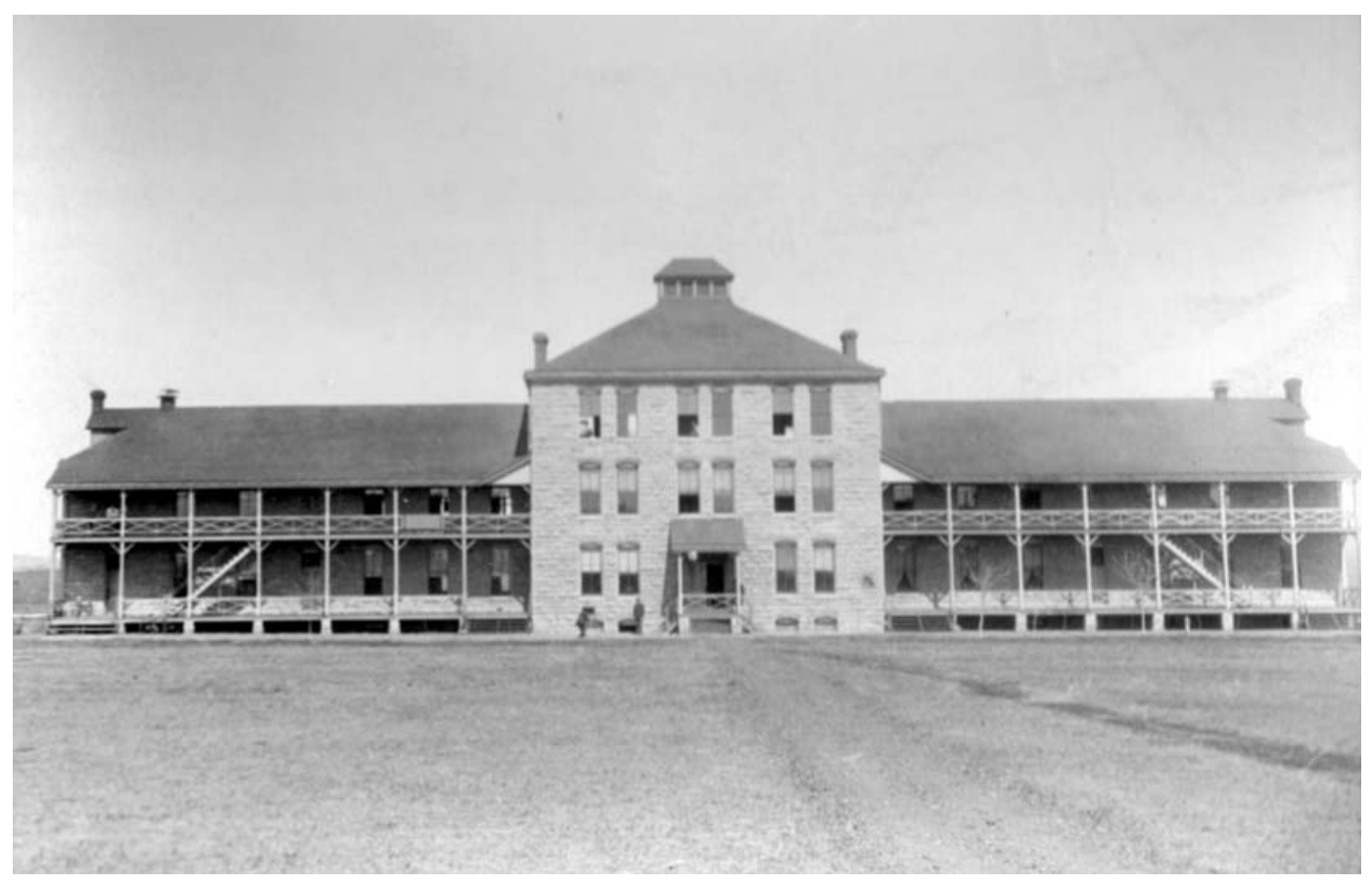

Figure 9. Artillery barracks in undated view (NARA).

The formality of the plans for both posts lent itself to the hierarchical relationships present at a military post. Commanding officer quarters occupied the most prominent locations in residential groupings, surrounded by (in order of rank) field and company officer quarters. At the artillery post, officer's quarters were located on a higher elevation than the barracks further denoting the difference in status. At the cavalry post, the parade field separated officer's quarters from barracks. ${ }^{41}$

\footnotetext{
40 In 1891, a small red brick ammunition magazine was constructed on post. The plan for the building is attributed to Captain Pond (electronic correspondences with William Hooker, Fort Riley, July 2009).

41 Crawford, "The Planning of Fort Riley," 6.
} 


\subsection{Captain Pond and Army standardized plans}

In J uly, 1891, adjudged to have completed his assignment, Captain Pond was transferred elsewhere. Since 1885, he had superintended the expenditure of $\$ 850,000$. That Pond had a tremendous influence on the development of Fort Riley is unquestionable. His influence on Army standardized plans, however, is somewhat unclear.

When Pond arrived at Fort Riley, a set of standard plans for officers housing was already widely in use. These plans, influenced by Quartermaster General Montgomery C. Meigs, had been recommended by the Board on Revisions of the Army Regulations in 1872. Although these plans were never issued as official Army regulations, despite objections by many construction quartermasters, they were widely adopted, either directly as issued or with some variations. ${ }^{42}$

Pond generally used the basic Army duplex form as put forth by the 1872 recommendations when he planned the construction of some new officer's quarters in 1887. However, he made some additions. For a group of double officers quarters represented by Buildings $7 / 7$ and 8/ 8 , he incorporated a full two-story, two-bay projecting front gable that divided the porch into two separate sections. He also added a polygonal bay to each side. This plan was later issued as a Quartermaster standard plan in 1887. Therefore, according to Mariani and Associates Architects, "under Pond's direction the widespread Army house form evolved into a more complex form." 43

Pond went on to develop the duplex form even further. He introduced a new duplex design to Fort Riley (and to Army construction) when another group of double officers quarters (represented by Buildings 15/ 15 and 17/ 17) was constructed beginning in 1889 along Forsyth Avenue. This new duplex, featuring an added four-bay projecting gable to the front, was later issued as Quartermaster Standard Plan No. 28 in 1891. The 1988 Mariani report claims that this may have been the prototype for several series of standardized plans issued as Numbers 45,90 , and 142.44 These plans were widely used during the 1890s and the first decade of the twentieth century.

42 Bethanie C. Grashof, A Study of United States Army Family Housing Standardized Plans: Volume IIntroduction, (Atlanta: Center for Architectural Conservation, College of Architecture, Georgia Institute of Technology, 1986), 14.

43 Mariani \& Associates, Study/Survey of Historically Significant Army Family Housing Quarters, 20.

44 Mariani \& Associates, Study/Survey of Historically Significant Army Family Housing Quarters, 20. 
Another standard Quartermaster plan that may have been influenced by Pond's work at Fort Riley relates directly to Buildings 1/ 1 and 100/100. These buildings were the Commanding Officers' quarters at the cavalry post and artillery post respectively. Building 100/ 100 was constructed in the Queen Anne style with Richardsonian Romanesque detailing. This design was also used later for field officers' quarters at Fort McPherson. Building $1 / 1$ at the cavalry post utilized an enlarged version of the Building 100/ 100 design. 45

The uncertainty of Pond's influence on standardized plans stems from the ambiguity of the role he played in the actual design of the officer's housing at Fort Riley. On March 3, 1888, the local J unction City Union praised Captain Pond for preparing the plans for the buildings at Fort Riley. The same newspaper three years later credited William Goding for having done the architectural work on a number of buildings at Fort Riley. Goding, an architect, was one of several specialists hired by Pond. The details of his professional working arrangement with Pond are unknown. Since both men's name appear on several plans used at Fort Riley, it is difficult to ascertain the specific role each man played. No further information about Goding has been located. 46

When Pond left Fort Riley in 1891, he was transferred back to Washington, D.C. By 1896, Pond had spent time at Madison Barracks and Plattsburg Barracks, both located in New York. During Pond's construction duty at Plattsburg Barracks (he enlarged and oversaw the rebuilding of the post), a series of standardized plans were issued by the Quartermaster Department. Two of these plans, utilizing variations of the four-bay front design built at Fort Riley, were used for the construction of officer's quarters at Plattsburg Barracks. ${ }^{47}$

\subsection{Fort Riley construction, 1892-1916}

After Pond left Fort Riley, the Army completed his 1887- 88 plan with a high degree of fidelity. Expansions of the Cavalry and Artillery School in the mid-1890s, 1903, and 1909 resulted in the construction of additional buildings including quarters for officers and non-commissioned officers, barracks, guard houses, stables, store houses, gun sheds, and other facili-

\footnotetext{
45 Ibid.

46 Ibid.

47 Ibid.
} 
ties. These buildings, all constructed generally in accord with Pond's plan, provided infill around Pond's previously established post. 48

By 1910, construction activity at Fort Riley began to wind down. Seven buildings were constructed in that year. From 1911- 1916, only five more buildings were erected. A squadron blacksmith shop (Building 246/139), built in 1916, was the last permanent structure erected during the building program associated with the establishment of the Cavalry and Light Artillery School at Fort Riley. ${ }^{49}$

\subsection{Limestone construction at Fort Riley, 1886-1916}

After the 1850s, buildings at Fort Riley were constructed of rock-faced ashlar limestone which was cheaper to produce than hammered limestone because the faces of rock-faced stones are left untouched as they come from the quarry. By the 1880s, the heavy, unfinished, rustic form of the rock-faced stone had become fashionable. Stone residences built at Fort Riley after the 1850s all have rock-faced walls and most have contrasting smooth-faced lintels and sills. ${ }^{50}$

By the beginning of the twentieth century, limestone quarters at Fort Riley had begun to evolve. While the rock-faced limestone walls mirrored those of the 1880s and 1890s, the wall thickness had shrunk to 6" as in the case of Building 425/174. (The wall thickness of the limestone structures constructed in the 1880s and 1890s is approximately 16-18" thick.) Also, the rock-faced limestone walls of the twentieth century buildings had a narrower course every other row. 51

\subsection{Events at Fort Riley, 1887-1917}

In 1887, as construction was under way on the Artillery and Cavalry posts, the 7th Cavalry returned to Fort Riley and stayed for the next eight years. This regiment, under the command of Colonel J ames W. Forsyth, was dispatched to the Dakotas in 1890 in response to a mass movement ("Ghost Dance" movement) of Sioux Indians on the reservations. The infamous

\footnotetext{
48 Crawford, "The Planning of Fort Riley," 6.

49 The Growth and Building History of Fort Riley.

50 Crawford, "The Planning of Fort Riley," 13.

51 Ibid.
} 
Battle of Wounded Knee resulted, during which about 30 cavalrymen and 150- 300 Indians were killed.

The Cavalry and Light Artillery Schools were officially opened in 1893 marking the beginning of Fort Riley's recognition as an important base of advanced military training. The schools offered theory and practical instruction in drill and firing practice, stable management, and horse training. Entire units, not individual men, were sent to Fort Riley to take part in the instruction the schools offered.

Originally, two regiments and ten batteries of artillery were assigned to Fort Riley for instruction. They remained until 1898, the year the SpanishAmerican War broke out. During the war, Fort Riley became sparsely populated as most of the troops were sent to Cuba to fight. The 20th Regiment, commanded by Colonel Frederick Funston, was sent over to the Philippines to put down an insurrection led by Emilio Aguinaldo. Colonel Funston and five officers infiltrated Aguinaldo's camp and captured him, thereby ending the fighting in the Philippines. ${ }^{52}$ After the SpanishAmerican War, the Cavalry School at Fort Riley resumed full-time operations again and eventually gained a reputation as one of the finest cavalry schools in the world.

In 1901, four large pack trains, which had seen service in Cuba, arrived at Fort Riley and set up a pack train station, later called Packers Camp. The trains were under the command of H.W. Daley, Chief Packer of the Army. In those days, the Army depended on long, mule pack trains to haul supplies. The men at Packers Camp were in charge of tending to the horses and mules and readying the pack trains. Initially, temporary quarters were erected for the personnel at Packers Camp. Later, three permanent structures were built there including a living quarters for the packers, muleskinners, and farriers (Building 1020), a blacksmith shop (Building 1022), and a stable (which was dismantled in the early 1930s). The pack trains and associated personnel remained at Fort Riley until the border difference with Mexico began in 1914.

In September and October of 1902, the first large-scale cavalry maneuvers ever to be held in the United States occurred at Fort Riley. Other largescale maneuvers were held in 1906 and 1908. In 1907, the Cavalry and

52 Schooley Caldwell Associates, Installation Design Guide: Fort Riley [Preliminary Submission], 1987, 120-5. 
Light Artillery Schools were consolidated and renamed the Mounted Service School although the training mission remained the same. A heavy emphasis was placed on practical training at the Mounted Service School, as revealed by a 1909 report. The report shows that student officers that year spent 1,126 hours in the saddle for an average of nearly five hours per working day for each student (Figure 10). 53

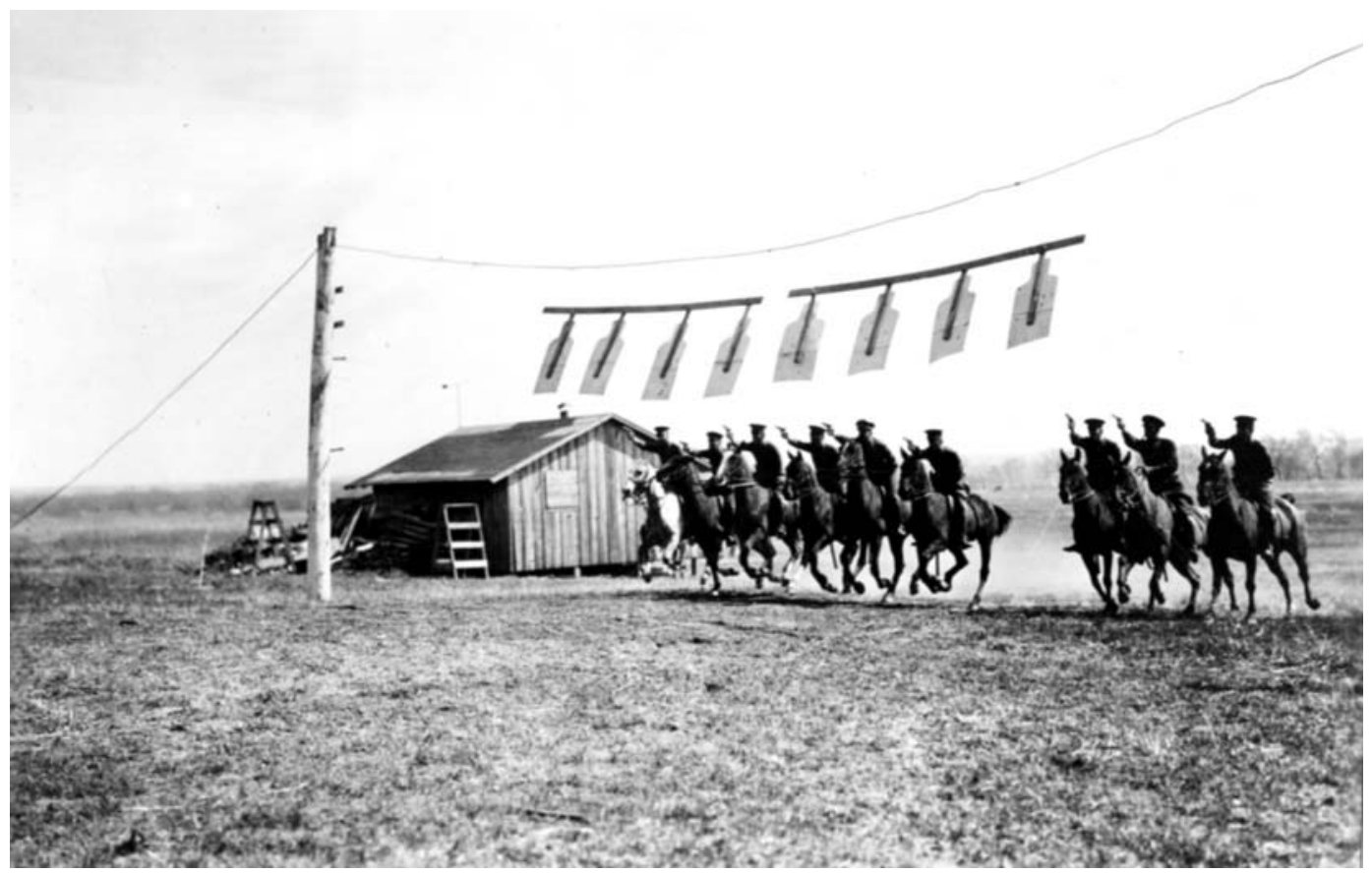

Figure 10. Cavalry pistol practice, 1927 (NARA).

Two additional training schools were established at Fort Riley around the turn of the century. The Farrier's and Horseshoe School was started in J anuary 1903 and the School for Bakers and Cooks was established in February 1905. At one time, while still a lieutenant, George S. Patton (to become a general of World War II fame), commanded the school for bakers and cooks. The Bakers and Cooks School later became the Food Service School, but was removed from Fort Riley in 1957. 54

In the years before the United States entered World War I, activities at Fort Riley centered on cavalry training, horse shows, fox and hound hunts, polo matches, and horse racing. During 1915-1916, courses at the cavalry school were temporarily suspended as troops were sent to the Mexican border in response to raids being conducted by the revolutionary general,

53 Fort Riley: Its Historic Past, 19.

54 The Growth and Building History of Fort Riley. 
Francisco "Pancho" Villa and his followers. General Funston was in command of the troops mobilized from Fort Riley.

\subsection{World War I}

Fort Riley played a significant role during the nation's involvement in World War I. In 1917, responding to events taking place in Europe, President Woodrow Wilson enacted a draft law authorizing federal conscription for the armed forces, effectively abolishing state militias and also allowing other men to be drafted into federal military service. This action created a high demand for trained officers; as a result, Fort Riley was selected as the site for a Reserve Officer's camp. There were 2,500 men trained at Fort Riley in 1917. Congress also appropriated funds to build a large training center at Fort Riley. Activities at the Mounted Service School practically ceased as construction began on the 14th National Army Cantonment. This temporary cantonment was named Camp Funston in honor of the late general, who died in February 1917.

In the months before America's 1917 entry into the First World War, Fort Riley's population quadrupled. Construction of Camp Funston began in J uly 1917, and it became one of the largest temporary training centers in the country. (Only the camp at Fort Lewis in Washington State is reputed to have been larger.) At Fort Riley, there were 1,401 buildings erected in three months at a site five miles northeast of the permanent post; the cost was $\$ 10$ million. Thousands of civilian workers completed the construction of Camp Funston under the direction of Post Quartermaster Lt. Colonel Fred Herman. 55

When Camp Funston was completed in December 1917, it was capable of housing and training 50,000 men (Figure 11). Consisting mainly of twostory wood buildings, the camp had complete waterworks, electrical, and refrigeration systems. Other facilities built simultaneously and associated with Camp Funston include a training camp for medical officers, a cavalry camp, a veterinary camp and remount depot, and an engineer camp. Also during this time, the post hospital (Building 500/108), originally built north of the artillery post in 1889, was greatly expanded. ${ }^{56}$

55 Schooley Caldwell Associates, Installation Design Guide: Fort Riley, 120-6.

56 Mariani \& Associates, Study/Survey of Historically Significant Army Family Housing Quarters, 17. 


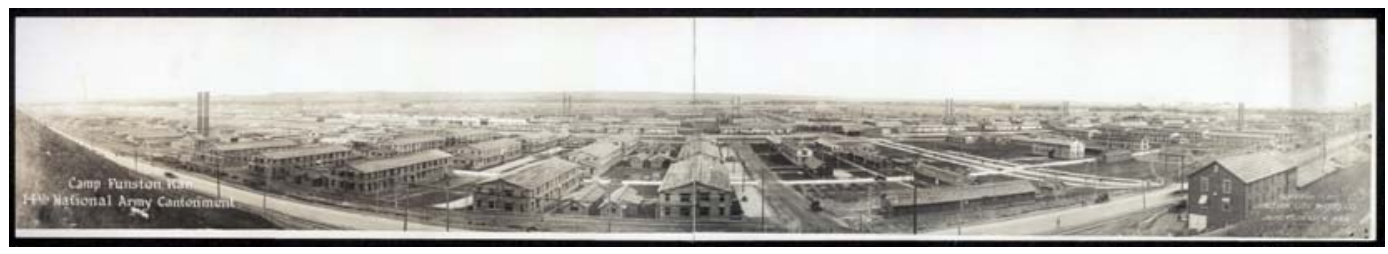

Figure 11. Panorama of Camp Funston, 1918 (Library of Congress).

In response to the needs of the soldiers stationed at Fort Riley during this time, a small city built entirely by private enterprises sprang up east of Camp Funston near the town of Ogden. "Army City," as it was called, was a four-block area containing saloons, stores, restaurants, theaters, business houses and pool halls.

World War I was the first large-scale war the United States participated in. The regiment, the basic unit of the Army until this time, was too small for the needs of a war the magnitude of World War I. Therefore the term "division," consisting of approximately 20,000 troops, was created and replaced the regiment as the basic unit of the Army. Four divisions in all were trained at Camp Funston during World War I. Two of these, the 89th Division and the 10th Division, were trained by Major General Leonard Wood before deploying to France.

\subsection{Between the World Wars}

After World War I, Camp Funston was dismantled and sold. Army City also disappeared. In 1919, the Artillery School at Fort Riley was discontinued and the Mounted Service School was reorganized and renamed the Cavalry School. The Cavalry School continued to train officers and enlisted men, primarily in the techniques and tactics of cavalry. It became an important educational center for the Army as much of the doctrine and tactics for both horse and mechanized cavalry were pioneered and developed there. Also, owing to the school's excellent equestrian training, most of the famous U.S. equestrian teams of the 1920s and 1930s trained at Fort Riley (Figure 12). 


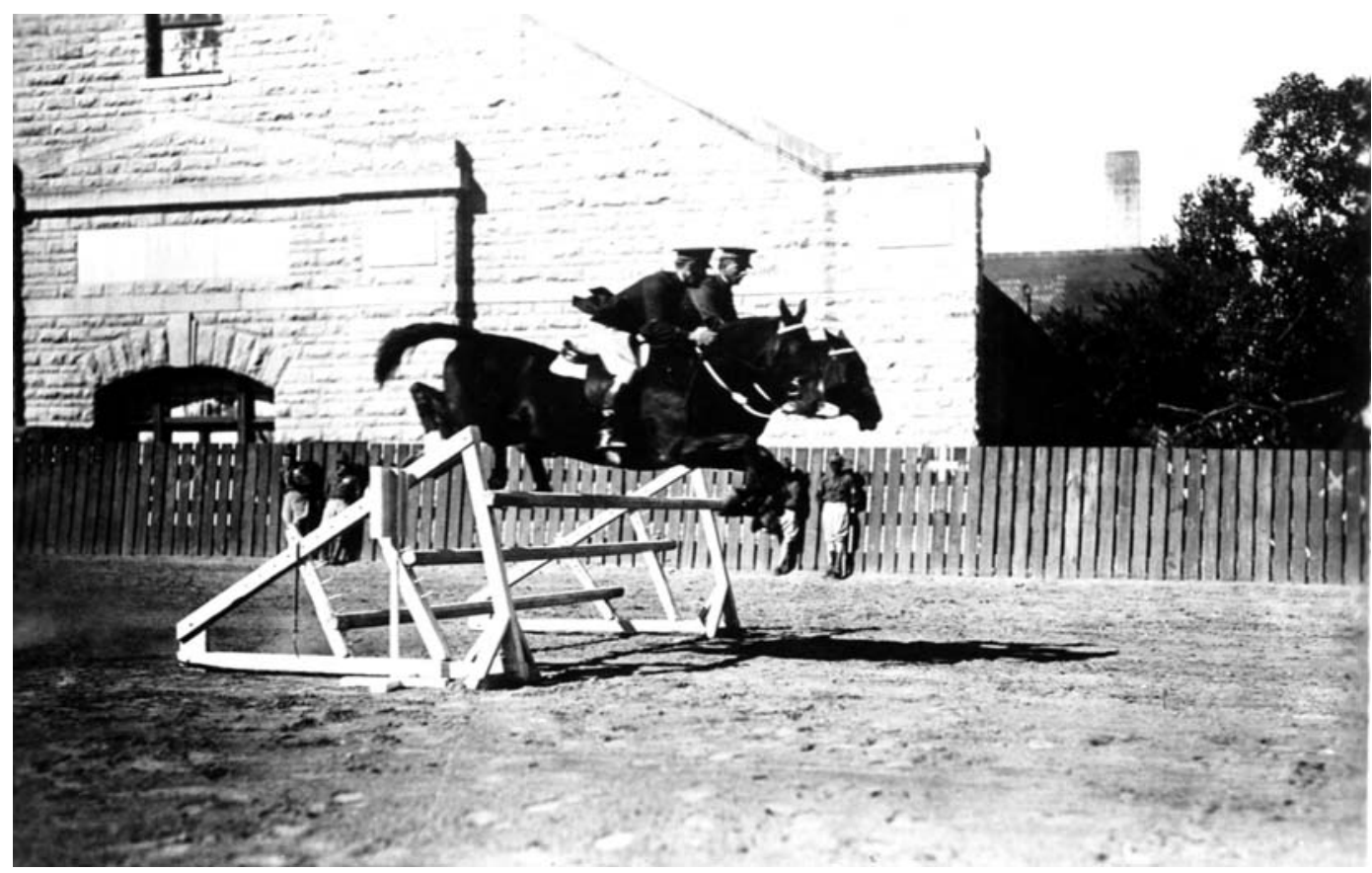

Figure 12. Jumping exercises at Fort Riley, undated (NARA).

The years between the two world wars were fairly quiet at Fort Riley. During these years, cavalry officers, officers from other arms and reserve components, and even officers from foreign countries, attended the Cavalry School for training in mounted tactics, equitation, and instruction in the care of horses. Horse shows, polo games, and hunts also became common again at Fort Riley during this period.

Early claims exist for the Fort Riley polo field to have been the site in 1912 of the first experiments in directing artillery fire from an airplane, with stovepipes for bombsites. H. H. "Hap" Arnold, a future Commanding General of the United States Army Air Forces and General of the Air Force, was among the participants. ${ }^{57}$ In 1921, Colonel Fred Herman selected the Smoky Hill Flats across the Kansas River as the location for a new airfield. The Fort Riley Flying Field opened in August of that year, and was home to the $16^{\text {th }}$ Observation Squadron. Initially, the primary responsibility of the fliers was to provide demonstrations and participate in training exercises for the cavalry school. The airfield was planned as a refueling point for cross-country flights and was equipped with metal hangars, underground fuel storage tanks, and lights for night operations. ${ }^{58}$ When the facilities

\footnotetext{
57 McGinley, “U.S. Army and Air Force Wings Over Kansas, Part Two," 3:341.

58 Andros, et al., Historical and Architectural Documentation Reports for Fort Riley, Kansas, 29. The initial facilities built at the airfield no longer exist.
} 
were completed in 1923, the airfield was named Marshall Army Air Field 59 after Brigadier General Francis C. Marshall, the Assistant Chief of Cavalry, who died the previous December in a plane crash. ${ }^{60}$

Marshall Field remained a quiet place for most of the 1920s and 1930s, with a mission of observation and photography during tactical exercises at Fort Riley, and performing aerial demonstrations. Aircraft from Marshall Field were also supplied by the $16^{\text {th }}$ Observation Squadron to other $7^{\text {th }}$ Corps installations. Major Arnold returned to the post as air base commander for over two years, beginning in March 1926. During his tenure, Marshall Field's fleet was mostly four or five De Havilland observation planes (DH-4s) and eight or ten Curtiss J ennies - all dating from World War I (WWI). A few more modern observation planes were acquired shortly after Arnold's arrival. ${ }^{61}$

In 1924, an area of Fort Riley located on the Pawnee Flats midway between the main post and Camp Funston was developed as a training site and camp for the National Guard. The site was named Camp Whitside in honor of Colonel Whitside who supervised the construction of the camp. Camp Whitside is situated at the bivouac site used by the troops who had taken part in the large scale maneuvers of 1902. It was first occupied during the summer of 1924.

\subsection{Construction at Fort Riley, 1927-1940}

There was very little construction at Fort Riley from the end of World War I until a major building program began at the installation in the late 1920s. This construction was part of the Army's nationwide building program begun in 1927 with the goal of replacing temporary WWI structures with permanent structures for a peacetime army. In his annual report of 1926, Secretary of War Dwight F. Davis stated that in the past he had expressed hope that "some relief might be granted the Army from the present inadequate and even dangerous living conditions for a large portion of officers, enlisted men, their wives and children-conditions which are rapidly becoming a national disgrace."62 A year before, he had described in detail the

59 Various records and documents use slightly varying names for the airfield. Within this report, the field will often be referred to simply as Marshall Field, which was a common practice.

60 McGinley, “U.S. Army and Air Force Wings Over Kansas, Part Two," 3:342.

$61 \mathrm{lbid}$

62 U.S. War Department, Annual Report of the Secretary of War, (Washington, D.C.: Government Printing Office, 1926). 
urgent necessity of removing Army personnel from dilapidated barracks and quarters left over from World War I. Finally recognizing the seriousness of the situation, Congress authorized a large Army building program in 1927. Construction under this building program continued nationwide until about 1940.

The original plan presented to Congress called for the expenditure of $\$ 110$ million over a ten-year period. Permanent barracks, quarters, and hospitals would replace dilapidated facilities. In addition, water and sewage systems were to be modernized, and up-to-date heating and cold storage plants would be provided. The construction of hangars, vehicle storage, and warehousing also eventually was included in the building program. ${ }^{63}$

Large-scale construction began at permanent posts nationwide in 1927 under the supervision of the Construction Division, Office of The Quartermaster General. By 1932, some nationwide progress had been realized in the Army's building program, and by 1933, approximately $\$ 50$ million had been appropriated by Congress for new construction projects at Army posts. However, with the worsening of the Great Depression and the consequent reductions in federal revenues, the program was interrupted and further improvements became temporarily impossible. It began to appear that the Army's building program would be put on hold for a few years.

The situation changed when President Roosevelt took office in 1933. The first "Hundred Days" of the Roosevelt administration produced the Civilian Conservation Corps (CCC), the Civil Works Administration (CWA) and the Public Works Administration (PWA). These programs were all designed to create jobs for the unemployed. Funds and/ or laborers from these relief organizations (except the CCC) were eventually used during the Army's major building program of this era. By the summer of 1933, the War Department was gratified to learn that funds from the newly created PWA would be allocated for the Army's building program. Consequently, the Army received \$61,413,614.50 in PWA funds for construction and repairs during the fiscal year 1934. Additionally, to providing work throughout the winter of 1933- 34 for thousands of unemployed, works projects were inaugurated at 265 Regular Army posts, national cemeteries and National Guard camps. Funds to the extent of $\$ 24,329,109$ were received

63 Lenoir Fine and Jesse Remington, The Corps of Engineers: Construction in the United States, United States Army in World War II, The Technical Services, (Center of Military History, Office of the Chief of Military History, United States Army: Washington, D.C., 1972), 46-47. 
from the Civil Works Administration, of which \$18,694,358 was expended for labor and the remainder for material. Under this program, 55,000 men were employed. ${ }^{64}$ In addition, on May 6, 1935, the Works Progress Administration (WPA) was established by an executive order of President Roosevelt. This new program was made responsible for "the honest, efficient, speedy, and coordinated execution of the work relief program as a whole and for the execution of that program in such manner as to move from the relief rolls to work on such projects or in private employment the maximum number of persons in the shortest time possible." 65 This organization thereafter assumed the dominant role in relief activities.

Fort Riley received many new permanent buildings and facilities during the Army's nationwide building program. A majority of the new buildings were quarters for officers, relieving the housing shortage Fort Riley had experienced in the 1920s. Built between 1928 and 1939, these quarters were constructed of brick or limestone and built around the edges of the old cavalry and artillery posts and at Marshall Army Air Field. Generally grouped in areas that were visually separated from the original 1887 plan, they were usually built around an open court plan or faced an open green. Standardized plans, designed by the Quartermaster General's Office in Washington, D.C., were used for the construction of most of the quarters erected during this period. These plans could be variously modified depending on the regional style. At Fort Riley, many of the residential structures built during this time feature Colonial Revival Style details. Both brick and limestone buildings were erected at Fort Riley during the Army's building program. The limestone quarters were constructed of either coursed or random rock-faced ashlar limestone.

Fort Riley received its first new permanent buildings under the Army's program in 1928. On December 3, 1927 a fire destroyed two temporary buildings that had served as quarters for thirty-two company officers, further exacerbating the housing shortage problem at the post. To relieve the resulting overcrowding, Congress appropriated funds for the construction of five four-family apartment houses for student officers at Fort Riley. These buildings were erected just north of the artillery post at Carpenter Place. The apartments were constructed of brick because it was quicker to

\footnotetext{
64 U.S. War Department, Annual Report of the Secretary of War, (Washington, D.C.: Government Printing Office, 1934), 9.

65 Executive Order No. 7034, May 6, 1935.
} 
construct than stone. Also, brick construction was considered cheaper than stone construction at that time.

In 1930, thirteen more officer's quarters were constructed at the main post of Fort Riley. Nine of these were duplexes for non-commissioned officers constructed just east of the artillery post. These brick structures, along with Buildings 425/ 174 and 426/ 173, are arranged in a horseshoe pattern. Three brick student officer apartments were added directly southeast of where the 1928 apartments were built. In 1930, the last quarters constructed was a brick duplex for non-commissioned officers. It was built at Riley Place, located north of the artillery post.

Building activity in 1931 included eight duplexes for non-commissioned officers and quarters for nurses. These structures were of brick construction. Two of the quarters for non-commissioned officers were built along Riley Place and the other six were constructed along Brick and Lower Brick Row, completing the open court begun in 1889.

As of 1931, all the new housing built at Fort Riley during the Army's housing program had been of brick construction. Compared to stone construction, brick construction was quicker and was believed to be more economical. However, since most of the previous permanent buildings were of stone construction, there were some influential people who felt that using stone for new construction would be more desirable than brick. In the summer of 1931, while visiting Fort Riley, Quartermaster General J ohn L. DeWitt, most likely influenced by Fort Riley's Constructing Quartermaster, Lieut. Col. Max A. Elser, came away "impressed with the desirability of building only stone buildings in connection with the future construction under the Housing Program in the section of the post where stone buildings predominate." 66 As a result, Elser was requested to prepare a report comparing the cost of brick construction to the type of stone construction used in the existing stone buildings at Fort Riley. ${ }^{67}$

Elser sent his report to the Quartermaster General's office in August 1931. In it, he stated that stone masonry could be cheaper than brick masonry if

\footnotetext{
66Leonard S. Doten, Captain, Q.M.C., Assistant, Memo to Constructing Quartermaster, Fort Riley, Kansas, July 14, 1931, National Archives, Washington, D.C., Office of the Quartermaster General, General Correspondence, Geographic File, 1922-1935, Record Group 92, Entry 1891, Box 1857, File 600.1.

67 Ibid.
} 
some procedural changes were made. Explaining why stone masonry had been more expensive than brick masonry in the past, Elser wrote:

...contractors were required to furnish stones which were perfect, imperfections of a very small nature being the cause of being rejected by the inspector. Very often, stone of this nature were laid up in walls getting by the inspector through some oversight, until they were several courses deep, and then coming to his attention were rejected and ordered torn out, causing the contractor a great amount of expense....To overcome losses experienced by these conditions, contractors were forced to add very materially to their bids, thereby making the use of stone as a building material prohibitive. 68

Obviously favoring the use of stone for future construction, Elser offered several reasons in his report why stone construction would be more desirable than brick construction. Elser claimed that if he were authorized to purchase some new equipment, such as saws and derricks, the stone could be quarried much cheaper than the manual method used until that time. Besides the existence of several quality stone quarries near the post, he argued that limestone buildings were sturdy, weathered well, were more attractive than brick buildings, were warm in winter and cool in summer. Also, stone could withstand extreme heat such as that experienced in fire. He pointed out that practically all the permanent buildings previously built at the post were of stone construction and the introduction of other types "would mar the harmony of present stone buildings."69

Elser conceded that stone construction required considerably more time because stone had to be quarried, cut and then hauled to the job site but, he believed that if the date of completion of stone masonry would be increased thirty to ninety days longer than that required by brick, more reasonable bids on stone construction would be submitted. ${ }^{70}$

A point raised by Elser that probably received the most attention in Washington was his assertion that many more men would be used in the con-

68 Max A. Elser, Lieut. Col. Quartermaster Corps, Constructing, Quartermaster, Memo to Quartermaster General, Washington, D.C., August 18, 1931. National Archives, Washington, D.C., Office of the Quartermaster General, General Correspondence, Geographic File, 1922-1935, Record Group 92, Entry 1891, Box 1857, File 600.1.

69 Max A. Elser, Lieut. Col. Quartermaster Corps, Memo to Quartermaster General.

70 lbid. 
struction of stone buildings as opposed to brick construction. He explained that a large amount of money expended in brick structures went to railroads for freight, which would be eliminated if stone were used. The money instead would go to laborers who would be needed to quarry, cut, and haul stone, and to masons and helpers who would be needed to lay up walls. ${ }^{71}$ During the Depression, when the government was looking for ways to create jobs for the growing number of unemployed, this last point might well have tipped the scales in favor of allowing stone construction for future buildings at Fort Riley. ${ }^{72}$

A letter dated 1 September 1931 to Elser from the Office of the Quartermaster General in Washington stated that in the future, careful consideration would be given in estimates and in the preparation of plans and specifications to using stone for new construction at Fort Riley. However, the letter stated that the policy would be that "where buildings forming groups have been constructed in brick that the completion of the group will be carried out in the same material."73 While brick buildings were still constructed at Fort Riley after 1931, stone construction resumed once again at the installation.

Limestone structures built at Fort Riley during the 1930s differed from the stone buildings constructed there from 1886-1916. When stone was used in the 1930s, it was used as a veneer rather than as the structure's main support. For example, Building 130/373, constructed in 1939, has machine-cut, 8"-thick walls as opposed to the 16"-thick walls of the late nineteenth and early twentieth century buildings. The coursing also changed; in 1939, Building 130/ 373 has random ashlar limestone walls. ${ }^{74}$

In 1934, Fort Riley was the recipient of twenty-six new quarters as a result of funds and labor received through the federal public works programs initiated in 1933 (as outlined earlier in this section). Funds and/ or laborers from the PWA and CWA were used in these projects. Fourteen buildings

\footnotetext{
71 Ibid.

72 When President Roosevelt's public works programs were initiated, Fort Riley's Constructing Quartermaster was urged by the Quartermaster General's Office in Washington to initiate approved construction "without delay" and was reminded that it was the purpose of the Public Works Administration "to put as many men to work, as quickly as possible, and to continue them at work, as far as feasible."

73 U.S. War Department, OQMG, Washington, Memo to Constructing Quartermaster, Fort Riley, Kansas, September 1, 1931, National Archives, Washington, D.C., Office of the Quartermaster General, General Correspondence, Geographic File, 1922-1935, Record Group 92, Entry 1891, Box 1857, File 600.1.

74 Crawford, "The Planning of Fort Riley," 4.
} 
were constructed at the main post while twelve buildings were constructed at Marshall Army Air Field for the Army Air Corps. Seven brick field officers quarters were built north of the Artillery Parade Field along Pershing Avenue and two brick student officer apartments were added along Sheridan Place. Two brick apartments were erected along Carpenter Avenue and three limestone apartments were built along Scott Place. Besides five company officer quarters and six quarters for non-commissioned officers, the airfield received a two-story 28-man barracks building with rooms on the first and second floors for non-commissioned officers and cooks. The buildings at the airfield were constructed of brick and were faced with buff-colored brick to match the hangar constructed in 1932 (Building 741/201).

There had been disagreement between the Commanding General of Fort Riley, General Harry A. Smith, and the Chief of the Army Air Corps, Major General J.E. Fechet, regarding the best location for quarters for the Air Corps officers and enlisted men. Smith had recommended that the quarters for the Air Corps be built at the main post "with a view to promoting mutual understanding and cordial cooperation between arms of the services." 75 Fechet, on the other hand, believed that the quarters should be at the airfield, since the activities of Air Corps would be approximately three miles from the main post. In a letter to the Adjutant General, he wrote, "I do not believe it to be practicable for officers and enlisted men to be compelled to travel this distance for meals and for travel to and from their point of work. It would be decidedly detrimental to the efficiency of the Air Corps if these buildings are constructed as recommended..."76 Fechet's opinion eventually won out, and the quarters for Air Corps personnel were constructed at the airfield.

For a time in the 1930s, Fort Riley served as the headquarters of the Civilian Conservation Corps (CCC), Kansas City District. Several temporary buildings were erected to house administrative personnel and CCC enrollees. The enrollees were organized at Fort Riley and sent to locations as far as Park Rapids, Minnesota to do conservation work. 77 The CCC buildings, believed to have been located southeast of the artillery post where ware-

\footnotetext{
75 Harry A. Smith, Major General, U.S. Army, Commanding, Letter to Adjutant General, Washington, D.C. January 17, 1928.

76 J. E. Fechet, Chief of the Air Corps, Letter to Adjutant General, April 18, 1928.

77 U.S. War Department, Adjutant General's Office, "Station and Strength Report of the Civilian Conservation Corps," November 30, 1933: 110.
} 
houses are now located, were transferred to the War Department in J uly of 1938. They have since been removed.

A cut in CCC appropriations in late 1937 forced the Director of the CCC to order the closing of all CCC camps operating on military posts by J uly 1 , 1938. ${ }^{78}$ It is unlikely that the CCC did any construction work at Fort Riley as post commanders were informed that work by the CCC was forbidden on barracks, permanent buildings, and fortifications. ${ }^{79}$

Fort Riley was, however, a beneficiary of the WPA program, as many men from all over Kansas were brought to Fort Riley to work on WPA projects. At first the men were housed at Camp Whitside, the National Guard camp. ${ }^{80}$ Later they were housed in a camp that utilized abandoned CCC buildings. The WPA camp was located in the same area as the CCC camp.

An impressive amount of work was done by WPA workers at Fort Riley. WPA work at Fort Riley included construction of transportation facilities, parks and recreational facilities (including grounds, landscaping, grading, and drainage), roads, highways, streets, drainage ditches, sanitary and sewer systems, distribution systems, and water supply systems. Additionally, WPA labor was used to demolish old buildings and to construct or improve many other buildings and facilities at the post.

WPA workers repaired, renovated, improved and modernized a good deal of barracks, quarters, and stables at Fort Riley. This work included eliminating fire hazards, underpinning buildings, replacing floors and plaster, modernizing plumbing, gas, electrical and heating facilities, painting, reconditioning gutters, and other miscellaneous improvements. In the months before America's entry into World War II, WPA workers also helped rebuild Camp Funston. In a 1941 letter to the Assistant Chief of Staff, Lt. Colonel Arthur Wilson of the General Staff Corps wrote that, since 1935, the WPA had expended approximately $\$ 4$ million on improvements at Fort Riley including the rehabilitation of practically all barracks and quarters. He also pointed out that the WPA had maintained a quarry which turned out a huge amount of stone, including that used in

78 Charles William Johnson, The Civilian Conservation Corps: The Role of the Army, Doctoral dissertation, (University of Michigan: 1968), 209.

79 Ibid., 206.

80 Guy V. Henry, Brigadier General, U.S. Army, Commandant, Memo to Colonel F.C. Harrington, Asst. Administrator, Works Progress Administration, 10 April 1936, National Archives, Washington, D.C., RG 69, Entry 651.101, Box 1360. 
the construction of the Academic building (Building 200/801). ${ }^{81}$ It is possible that the work done by WPA workers on the older buildings at Fort Riley may have been extensive enough to create a second period of significance for those structures. However, that determination was beyond the scope of this project but may be an area for future research.

In 1939, fourteen additional officers quarters were constructed at the main post of Fort Riley. PWA funds, and WPA funds and workers were used in the construction of these buildings. At Stone Court, located just north of Brick Row, ten duplexes for non-commissioned officers were constructed of native limestone. A two-car stone garage was constructed simultaneously for each of these quarters. Riley Place received three brick duplexes and one stone duplex for non-commissioned officers added to Brick Row. These buildings were the last permanent quarters constructed at Fort Riley during the Army building program that began in 1927.

By the close of 1939, Fort Riley had received 65 new officer's quarters, a fire station, a theater, several warehouses and equipment stores, several garages, a new laundry facility, several magazines, and water well and pump buildings. Construction under the Army's building program continued at Fort Riley into 1940 although the program had begun to wind down. Permanent construction in 1940 included several detached garages and the construction of Building 200/ 801, known as Patton Hall, along Henry Avenue just east of the Cavalry Parade Field.

Several permanent miscellaneous and support structures were erected at Fort Riley in 1941 as the installation began to prepare for the nation's possible entry into World War II. Construction in that year included a laundry boiler house (Building 184/239), three support buildings at Marshall Army Air Field (Buildings 743, 751/ 205 and 754/208), ten magazines in the Ammunition Storage Area (located north of the main post), a sewage treatment plant (Building 2592) and two water well and pump buildings (2598 and 2599) along Trooper Drive.

\subsection{World War II}

In 1939, when war was again raging in Europe, the United States began arming itself. The Army had initiated a vast expansion program that in-

\footnotetext{
81 Arthur R. Wilson, Lt. Colonel, General Staff Corps, Memo to Assistant Chief of Staff, November 3, 1941.
} 
cluded the mechanization of the U.S. Cavalry. Early in the 1930s, the cavalry began to use motor vehicles with its units, blending the firepower of the cavalry with the increased mobility of the motor vehicle. Gradually, the cavalry developed an entirely mechanized force that was the forerunner of the Armored Force. Reorganization, retraining, and reequipping of the Cavalry for combat as separate units and as elements of Armored and Infantry divisions were necessary. To train officers and enlisted men for this purpose, an area directly west of the main post, called the Republican Flats, was chosen to be the site of the Cavalry Replacement Training Center. This area was later named Camp Forsyth. During the war, 150,000 horse and mechanized cavalry troops were trained there. ${ }^{82}$

Construction of Camp Forsyth, a large temporary cantonment, began in December of 1940 and was completed in March of 1941. This is a remarkably brief period considering that the camp consisted of 210 barracks, 50 mess halls, officer's quarters, warehouses, and administration and headquarters buildings. In addition, a theater, a service club, a swimming pool, indoor and outdoor boxing arenas, tennis courts, football fields, five dispensaries, a dental clinic, two chapels, and a guest house were also constructed. 83

Fort Riley experienced another massive growth in troop size as the likelihood of the United States entering the war grew more probable. To accommodate this increase in population, Camp Funston was rebuilt. Between November 1940 and J uly 1941, 890 temporary buildings, 77 miles of electric lines, 23 miles of roads, 3.4 miles of railroad, and two viaducts were constructed. Camp Whitside, located between the main post and Camp Funston, was expanded in 1940 and 1942 and was used as the cantonment's hospital.

The 2nd Cavalry Division was the first unit to train at the rebuilt Camp Funston. As the war progressed, Camp Funston became the training ground for organizations destined for every theater of the war. In 1942, the camp was adapted for training armor. The 9th Armored Division, activated and trained at Fort Riley, went on to distinguish itself in the important capture of the Remagen Bridge over Germany's Rhine River.

82 The Growth and Building History of Fort Riley.

83 Schooley Caldwell Associates, Installation Design Guide: Fort Riley, 120-8. 
At the beginning of WWII, Marshall Field had two hangars and three unpaved landing strips; the longest was 3,700'. In order to handle the larger, heavier planes coming into use, the runways were paved and lengthened. In all, two 4,500' long, 150' wide concrete runways, six taxiways, and 5,400 square yards of parking apron were created to support the wartime aviation needs. ${ }^{84}$ The 1st Observation Squadron was shipped to the Canal Zone in late 1941, and the $6^{\text {th }}$ Observation Squadron (Special), activated at Fort Sill in February 1942, moved to Marshall Field that April. The unit was re-designated the $6^{\text {th }}$ Reconnaissance Squadron (Special) in J une and again as the $2 \mathrm{~d}$ Composite Squadron (Special) in October. By this time the original 1942 complement of 15 liaison planes had been supplemented with 15 P-39s and five B-25s. ${ }^{85}$ Missions had also expanded from an observation and photography focus to include tactical air missions such as air-ground support demonstrations, simulated strafing, bombing, and chemical warfare missions.

As the facilities at Fort Riley expanded during World War II, so did its boundaries. In 1941 and 1942, farmland was acquired directly north of the original reservation and west of the town of Ogden. Approximately 31,720 acres were added to the existing 19,446 acre reservation. ${ }^{86}$ The area became a troop training ground and is now part of the artillery impact area. In total, approximately $\$ 28,681,000$ was spent on land and construction at Fort Riley between 1940 and 1945. ${ }^{87}$

Throughout World War II, it became increasingly apparent that a horse cavalry did not meet the requirements of modern warfare. The last major action to be undertaken by mounted cavalry came early in 1942 when the 26th Cavalry covered the Army's retreat to Bataan during the Philippine Campaign. ${ }^{88}$ Although the era of mounted cavalry was ending, two graduates of the Mounted School at Fort Riley greatly contributed to the Allied victory in World War II. General George S. Patton outfoxed the man known as "The Desert Fox," German General Erwin Rommel in Tunisia, commanded the 7th Army in the conquest of Sicily, and led the 3rd Army in the battle for France. Major General J onathan Wainwright served as

\footnotetext{
84 McGinley, “U.S. Army and Air Force Wings Over Kansas, Part Two,” 3:342..

$85 \mathrm{Ibid}, 3: 343$.

86 Ibid.

87 U.S. War Department, Post War Utilization Studies: Fort Riley, Kansas, (Washington, DC: Office of the Chief of Engineers, 1945), 1.

88 The Growth and Building History of Fort Riley.
} 
General Douglas MacArthur's Senior Field Officer and later commanded troops on Corregidor, the critical island in the Philippine's Manila Bay. He was captured by the J apanese and imprisoned for 39 months, yet he survived and was present on the deck of the U.S.S. Missouri at the J apanese surrender. 89

\subsection{The Cold War begins}

\subsubsection{Allies become adversaries}

The seeds of the Cold War had been sown during WWII, when the United States and the Soviet Union found themselves allies in the fight against Nazi Germany. ${ }^{90}$ Although they fought together against a common enemy, both countries had vastly different worldviews and ideologies. Tensions between the Soviet Union and the United States developed quickly after WWII as each country struggled to create a post-war world based on its own political ideologies.

Particularly troubling to leaders in the United States was the Soviet support of communist political leaders in Hungary, Czechoslovakia, Greece, Turkey, Korea, Vietnam, and elsewhere. It appeared to American leaders that the Soviet Union was an aggressor nation bent on world conquest. Fearing that the fall of one nation to communism would have a "domino effect" on surrounding nations, President Henry S. Truman's administration adopted a policy of opposing communism anywhere and everywhere. This policy, called containment, would see every regional conflict as a struggle between the United States and the Soviet Union.

Tensions between the two nations reached a critical point in 1948- 49 when the Soviet Union blocked access to West Berlin. Although a massive airlift campaign by the United States prevented war, the incident highlighted the military strengths and weaknesses of both countries. The Soviets held a substantial advantage in conventional forces, while the United States was still the sole possessor of the atomic bomb. Leaders in the United States, faced with post-war budgetary restrictions, soon came to view nuclear weapons as a relatively inexpensive and politically acceptable means to offset any Soviet military advantages. The United States soon be-

\footnotetext{
89 Mariani \& Associates, Study/Survey of Historically Significant Army Family Housing Quarters, 17-18.

90 This section is extracted from: Patrick Nowlan, Identification and Evaluation of Cold War Properties at Fort Bliss, Texas, (Champaign, IL: Construction Engineering Research Laboratory, 1999), 1-4.
} 
gan producing smaller yet more powerful nuclear bombs, while at the same time dramatically reducing its defense budget.

In April 1949, the United States, Canada, and ten Western European countries joined together in a military and political alliance known as the North Atlantic Treaty Organization (NATO). Greece, Turkey, and West Germany joined the ranks of NATO within the next six years. The treaty provided for United States military assistance to Western Europe in the event of a Soviet-backed invasion. To fulfill its NATO commitment, the United States looked to its nuclear bomber force as a cheap and effective solution. The new B-36 intercontinental bomber could threaten targets deep within the Soviet Union from bases on United States soil. Although the United States viewed NATO as a defensive alliance, Soviet officials viewed NATO as an organization whose ultimate aim was to push the Soviet Union back to its pre-war position. The Soviets responded by creating an alliance of their own with the communist governments of Eastern Europe. This communist alliance was formalized in 1955 with the signing of the Warsaw Pact.

A number of significant developments greatly impacted the defense policy of the United States in the 1950s and 1960s. The first was the Soviet detonation of an atomic bomb in August 1949. This event ended the nuclear monopoly of the United States and provided the impetus for the United States to develop the more powerful hydrogen bomb. Only a few months after the Soviet atomic detonation, Mao Zedong's Red Army defeated the forces of Chiang Kai-shek, the United States' longtime ally in China. Mao then established mainland China as the People's Republic of China. When the Soviets consolidated their alliance with the Chinese, it appeared as if half a billion people had joined the enemy camp. Faced with these new threats, troubled leaders in the United States began to reassess the nation's defense policies and determined that America needed an immediate build-up of nuclear and conventional forces.

Adding to the anxiety was the invasion of South Korea by communist North Korean forces in J une 1950 (see detailed section below). Suspecting that the invasion was undertaken with Soviet approval and fearing that the Korean development might be a prelude to similar action in Europe, Congress drastically increased the U.S. defense budget. President Truman quickly sought and received Congressional approval to send United States forces to Korea to help repel the invasion. A United Nations Security Council resolution supporting the action soon followed. 


\subsubsection{Korean War, 1950-1953}

The North Korean invasion of South Korea began at 4 a.m. on 25J une 1950, when eight divisions and an armored brigade crossed the $38^{\text {th }}$ parallel dividing the two countries. ${ }^{91}$ This was the official start of the Korean War which lasted until the military armistice was signed J uly 27, 1953.92 The North Korean government had attempted insurgency in South Korea with the support of the Soviet Union for several years. After it became apparent this would not work, the North started their direct attack. They were sure of their victory against the government of the South for several reasons. North Korea had a well-trained army of 135,000 that had seen action in World War II versus South Korea's new and untested army of 95,000 created after the 1948 division of Korea. The North also was superior in military hardware, being supplied by the People's Republic of China and the Soviet Union; the South had no tanks, a minimal air force, and a small amount of used U.S. equipment. North Korea (and the Soviet Union) also assumed that the United Nations would not intervene in any "internal" Korean conflict, as well as knowing the U.N. had never yet authorized the use of armed force. 93

Three days after the invasion, the North Korean army was in the South Korean capital of Seoul. This prompted United States to act, including pressuring the United Nations into a military response on J une 27, after demands for withdrawal from South Korea were ignored. President Truman authorized General Douglas MacArthur to use U.S. military power against North Korea forces below the $38^{\text {th }}$ parallel.

By the time MacArthur received the orders, the North Koreans had crossed the Han River south of Seoul. MacArthur had at his disposal the ground troops of the 8th Army in J apan with the $1^{\text {st }}$ Cavalry Division, and the $7^{\text {th }}$, $24^{\text {th }}$, and 25th Infantry Divisions and the $28^{\text {th }}$ Regimental Combat Team in Okinawa. Air support was a problem as the United States Far East Air Forces were designed as a defensive force which was unfortunately not equipped to provide tactical air support for forces in South Korea. The United States Asian naval forces (Naval Forces, Far East) consisted of only

91 "An Overview of the U.S. Army in the Korean War 1950-1953," http://korea50.army.mil/history/factsheets/army.shtml; "The Korean War: Narratives Extracted from CMH Commemorative Posters," http://www.army.mil/cmh-pg/reference/Korea/kw-narr.htm.

92 Army Historical Series, “The Korean War, 1950-1953," in American Military History, http://www.army.mil/emh-pg/books/AMH/AMH-25.htm, 545, 568.

93 Ibid., 545-546. 
five combat ships. Due to the lack of U.S. forces in the area, MacArthur chose to take action with small forces where needed so as to buy time until reinforcements could arrive. At that point, massive actions were needed to repel the North Korean forces. The first actions taken by American troops were disastrous with the larger, well-equipped North Koreans easily overtaking the outnumbered and poorly equipped Americans. ${ }^{94}$

On J uly 7, the United Nations authorized a unified command, United Nations Command (UNC), under General MacArthur to coordinate the troops of the 29 member nations offering military and support assistance. Coordination took several months and by the beginning of August, the North Korean army had taken control of almost the entire Korean peninsula. ${ }^{95}$ It was not until September that the UNC forces had the equipment and troop strength to take back South Korean territory. By the end of September, the North Korean army largely had been driven back above the $38^{\text {th }}$ parallel. MacArthur ordered troops to advance and attack above the $38^{\text {th }}$ parallel to quickly take out the Northern troops, training camps, and seaports before the winter. President Truman gave orders to General MacArthur to send forces north of the $38^{\text {th }}$ parallel unless Chinese or Soviet troops were encountered. ${ }^{96}$ When the UNC troops encountered Chinese troops, this was thought to be either small numbers of volunteers or an intimidation tactic by the Chinese to stop UNC aggression into the north; intelligence on this issue was slim. By the end of November, it was clear that Chinese troop strength was over 300,000 and MacArthur ordered withdrawals back to the $38^{\text {th }}$ parallel to prevent being enveloped by the Chinese and to build a stronghold to hold off any subsequent attacks. ${ }^{97}$

But on New Year's Eve, the Chinese and North Korean troops opened an attack to the south that pushed the UNC troops back to 40 miles south of Seoul. ${ }^{98}$ To build troops, several methods were used: (a) United States National Guard Reserves were called up for duty with extended service of 21 months, (b) the Selective Service was called upon for stepped up recruiting, and (c) terms of enlistment were extended by twelve months. Congress authorized supplemental appropriations just less than $\$ 20$ billion early in the conflict. South Korea and the United Nations troops regained

\footnotetext{
94 Ibid., 546, 548-549.

95 Ibid., 550, 552.

96 "An Overview of the U.S. Army in the Korean War," 3.

97 Army Historical Series, “The Korean War, 1950-1953," 557-558.

98 Ibid., 561.
} 
the 38 th parallel early in 1951 and there the action stalled. Negotiations began between the two sides and their allies, lasting until the armistice in 1953.99

\subsubsection{Death threats from the skies}

While U.S.-dominated United Nations forces fought in Korea, America's efforts to create a hydrogen bomb proceeded rapidly. ${ }^{100}$ In November 1952, America's scientists detonated the world's first thermonuclear device at Eniwetok Atoll in the Pacific Ocean, paving the way for the development of the hydrogen bomb. Nevertheless, security of the United States was far from being ensured as the Soviet Union detonated its first hydrogen bomb only ten months later.

At that point, the Cold War acquired a new and much more disturbing character. For the first time in history, two competing powers possessed the means to completely destroy the human race. Expressed through the American policy of "massive retaliation," the United States relied upon the longrange bombers of the Air Force Strategic Air Command (SAC) as the best deterrent to a possible Soviet nuclear attack, by means of a devastating retaliation threat to targets in the Soviet Union.

Concurrent with the American effort to produce a fleet of long-range bombers, the Soviet Union began investing heavily in the development of longrange missiles. Proof of the advanced state of the Soviet missile program came on 4 October 1957 when one of their rockets placed the world's first man-made satellite, Sputnik, into orbit. During the following November, a Soviet rocket placed the 1,120-pound Sputnik 2 satellite, carrying a live dog, into orbit. This launch had tremendous strategic implications. A booster capable of carrying such a payload into space would also be capable of delivering a nuclear bomb to targets within the United States. Leaders in both countries realized that such a development would effectively offset the American advantage in long-range bombers.

At the time of the Soviet Sputnik launches, the U.S. Army, Air Force, and Navy were all involved in their own long-range missile research and devel-

99 Dr. Robert W. Coakley, Highlights of Mobilization, Korean War, http://www.army.mil/cmhpg/documents/Korea/kwmob.htm, 1, 3; Army Historical Series, “The Korean War, 1950-1953," 561.

100 This section is extracted from: Nowlan, Identification and Evaluation of Cold War Properties at Fort Bliss, Texas, 4. 
opment efforts. A fierce inter-service rivalry over control of guided missiles ensued as each service sought to define its role and mission. The Air Force missile program became the most extensive, moving from early winged missiles to the Thor Intermediate Range Ballistic Missile (IRBM) in 1959, the Atlas and Titan Intercontinental Ballistic Missiles (ICBMs) in the early 1960s, to the Titan II and Minuteman ICBMs by the mid-1960s. The latter two missiles formed the backbone of SAC's land-based nuclear deterrent force for most of the remainder of the Cold War.

\subsubsection{Flashpoint in Berlin}

Realization of the futility of mutually assured destruction provoked a debate in the late 1950s as to what type of war the United States should be prepared to fight - general versus limited, nuclear versus conventional, or combinations of all these. ${ }^{101}$ The stalemate imposed by the achievement of mutually assured destruction helped to prevent a nuclear holocaust, but left the Soviet Union and the United States few options for deciding military superiority in the battle between communism and democracy. In 1961, this pent-up military energy nearly found expression in Berlin.

When J ohn F. Kennedy stepped into the presidency in early 1961, tensions already had been brewing in Berlin for several years. Resenting the Western powers' occupation of Berlin, Khrushchev initiated a diplomatic push for control of the entire city. ${ }^{102}$ To the West, Berlin was a primary front against Soviet expansionism, and it was vital to retain a foothold. After diplomatic channels proved unsuccessful for achieving Khrushchev's demands, he threatened war. Kennedy rose to the threat, calling for a large military buildup in preparation for a possible conflict. ${ }^{103}$

Khrushchev backed down from the demand for control of Berlin, moving instead that August to construct a wall between the two halves of the city. This only served to raise tensions, as access through the established checkpoints became increasingly problematic. In September, President Kennedy augmented U.S. troop levels again, and within a month nearly 120,000 reserve troops (including two National Guard divisions) had

\footnotetext{
101 Ibid.

102 Sheila A. McCarthy and Roy L. McCullough, Fort Hood Military Family Housing of the Cold War Era: McNair Village \& Chaffee Village, (Omaha, NE: Midwest Regional Office, National Park Service, 2003), 23.

103 Ibid., 24.
} 
joined the active Army. The Army itself had an additional strength of 80,000 troops, and equipment procurement and troop training were accelerated. ${ }^{104}$ By that time, ten U.S. tanks had taken up residence at a main crossing point, Checkpoint Charlie. On the $27^{\text {th }}$ of that month, ten soviet tanks approached to within 100 yards, and both sides prepared for battle. A sixteen-hour standoff ensued, during which time both powers put all resources on alert, and the Soviets were authorized to return force with force. Kennedy asked Khrushchev to withdraw his tanks, telling him the United States would then do the same. ${ }^{105}$ The Russian-American face-off ended quietly, with both sides aware of how close they had come to war.

\subsubsection{Geopolitical competition and proxy wars}

One of the available options for showing military might and technological supremacy was through fighting proxy wars. It wasn't necessary for the U.S. and the Soviets to fight on each others' soil when they could support, supply, and sometimes even provide soldiers to third-party conflicts. These conflicts usually occurred in developing nations, where military assistance was needed and current political ideology was seen to be a risk to democratic ideals. During the early 1960s, this pent-up military energy nearly found expression in Cuba, and then flared to life in Vietnam.

Finding American missiles in Turkey too close for comfort, Khrushchev decided to retaliate by placing missiles on the island of Cuba, where a new communist regime had recently won control. Beginning in the summer of 1962, missile sites were under construction and military hardware was on the seas, bound for Cuba. American spy planes captured images of the missile sites on October 14, kicking the administration into a fierce debate about the U.S. response, with options ranging from air strikes to invasions to a naval blockade. This naval blockade option was selected, and on 21 October, forces and weapons were put on alert, with 180 ships sent out to block incoming Soviet military materials. This instigated an alert for Warsaw Pact forces, and Khrushchev threatened to sink the American ships.

The Unites States began intercepting ships on 25 October, while Kennedy prepared an invasion force by massing troops in Florida and the Caribbean and sending two aircraft carriers toward Cuba. Diplomatic efforts concur-

\footnotetext{
104 Walter G. Hermes, American Military History, Chapter 27: "Global Pressures and the Flexible Response," (Washington, D.C.: US Army Center of Military History, U.S. Army, 1989), 595.

105 McCarthy and McCullough, Fort Hood Military Family Housing of the Cold War Era, 24.
} 
rently kicked into high gear, with the Russians making the first offer to dismantle the missiles if the United States promised not to invade Cuba. Further intense negotiations occurred 26- 27 October, resulting in an agreement with those provisions, and also included an unwritten commitment from the United States to remove its missiles from Turkey. The missile sites in Cuba were dismantled, and the missiles in Turkey withdrawn; the ships returned home, and both sides took very deep breaths. ${ }^{106}$

By this time, however, years of U.S. involvement in a simmering Southeast Asia was just about to become more complicated. Ruled by China for a millennium, Vietnam had reverted to feudal self-rule for nearly another thousand years before the French conquest of Indochina began in the 1850s. American interest in the area was very limited until 9 March 1945 when the French asked for U.S. assistance to defend against a J apanese coup. After sending in air strikes and helping to bring about a J apanese surrender, American interests in the area continued with a small presence on and off, until the French were defeated in 1954. The country then was divided, with communists receiving control of North Vietnam. ${ }^{107}$

During the late 1950s, President Eisenhower had tried to limit the spread of communism in the Vietnam area through direct financial aid to support the anti-communist government and military of South Vietnam Premier Ngo Dinh Diem. By the end of Eisenhower's term, this aid reached more than $\$ 1$ billion, and the military advisory group had expanded to 740 officers and enlisted men on the ground. ${ }^{108}$ President Kennedy signed the Treaty of Amity and Economic Relations in 1961, "declaring intention to render military aid to the Republic of Vietnam." 109 The Soviet Union was providing support to the Pathet Lao in Laos; Kennedy resolved to make a stand in South Vietnam to stop this spread of communism. By the end of 1962, there were 11,000 U.S. officers and enlisted men in Vietnam, including pilots flying combat missions. ${ }^{110}$ With President Kennedy's assassination less than one year later in November 1963, his successor, President Lyndon B. J ohnson took control of the U.S. military's

\footnotetext{
106 Ibid., 25-27.

107 Ronald H. Spector, Advice and Support: The Early Years 1941-1960, (Washington, D.C: US Army Center of Military History, United States Army, 1983), 3, 7, 28-33, 58, 77.

108 Joel D. Meyerson, United States Army in Vietnam: Images of a Lengthy War, (Washington, D.C.: US Army Center of Military History, 1986), 36.

109 Lt. Gen. Carroll H. Dunn, Vietnam Studies: Base Development in South Vietnam, 1965-1970, (Washington, D.C.: Department of the Army, 1991, 6.

110 Meyerson, United States Army in Vietnam, 69, 77.
} 
involvement in Vietnam, and by 1964 the cold war had once again become a hot war.

\subsection{Early Cold War years at Fort Riley}

Immediately after the end of World War II, the War Department set about determining which installations to keep going, which to mothball, and which to close permanently. As part of this process, utilization studies were conducted for installations across the country during September 1945. The resulting report provided a snapshot of Fort Riley at the end of one era and the beginning of another. Containing 54,184 acres, the "old post" was noted as the home of the Cavalry School, having always been primarily garrisoned by Cavalry troops. ${ }^{111}$ At the prevailing space allocation of 80 square feet per man, the installation could provide housing for approximately 21,000 personnel. ${ }^{112}$ The facilities on post ranged from mostly permanent structures on the Main Post to the mobilization buildings found at Camp Funston, Camp Forsyth, and Camp Whitside.

The facilities on post were deemed to be adequate from an engineering standpoint for continued post-war use, with the exception of needed updates to the utility systems and the creation of permanent housing for bachelor officers. It was also recommended that the mobilization type barracks be remodeled for the post-war use by the proposed strength of 8,620 enlisted personnel. Total cost for the suggested upgrades and new construction was estimated at $\$ 5.8$ million. ${ }^{113}$

At Fort Riley, the first order of business after World War II was handling its share of the massive numbers being discharged from military service. A separation center, (as facilities for out-processing departing soldiers were called), went into operation September 16, 1945 in Camp Funston and ran until December 10, 1945 processing 4,092 GIs during that time. ${ }^{114}$ To relieve congestion at Fort Sheridan and other separation centers that built up over the following year, a new separation center opened at Fort Riley in October 1946 with the capacity to process 25 people per day. ${ }^{115}$

\footnotetext{
111 U.S. War Department, Post War Utilization Studies, 1.

112 Ibid., 2.

113 Ibid., 2-3.

114 “New Group to Camp Funston," Junction City Union, 2 October 1946, 1.

115 “New Center Opens Monday," Junction City Union, 11 October, 1946, 1.
} 
Over the next few years, the training mission continued on a daily basis, and little occurred to alter the routine. There were however, a few events and distinguished visitors that made the news, sometimes in a big way. The largest impact on the installation itself and those in the vicinity was the massive flood that occurred J uly 1951. Heavy rains that had been falling in the area for several months intensified during 9-12 J uly. In some areas as much as 17 inches fell, and the resulting flood spread over large areas of Kansas and Missouri. The Republican and Smoky Hill Rivers bordering the east side of Fort Riley were at flood stage by $10 \mathrm{~J}$ uly and kept rising as they joined the Kansas River just above Marshall Field. ${ }^{116}$ By the following day, the J unction City newspaper was alerting readers to the "huge new floods" pouring down area waterways, with more heavy rain in the forecast. ${ }^{117}$ Particularly hard hit by this point was the nearby town of Manhattan, where the National Guard had been called out to provide assistance. Flood waters at Fort Riley were rising simultaneously, and Marshall Field was closed as two runways were inundated; residents of the housing at the field were evacuated that evening. J unction City and Manhattan both began evacuations, and highways to Fort Riley were cut off. The Union Pacific station at the fort was already under two feet of water, and nearby troop housing and offices were evacuated, with about 400 soldiers leaving the flooded area. ${ }^{118}$ The floods reached their peak the next day, $12 \mathrm{~J} \mathrm{uly,} \mathrm{with} \mathrm{the} \mathrm{Kansas} \mathrm{River} \mathrm{cresting} \mathrm{at} \mathrm{what} \mathrm{was} \mathrm{thought} \mathrm{to} \mathrm{be} \mathrm{its}$ highest level in history. Evacuations started the evening before at Fort Riley quickly intensified. Camp Funston was entirely depopulated, with approximately 1,100 men moving into a tent city on the hills above the camp. Most of the buildings at Camp Funston were flooded to the second floors (Figure 13). Marshall Field runways were 10-12' underwater, and the main hangar was flooded to a depth of 14' (Figure 14). The water in the area around the rail depot was 4- 5' deep. The Main Post and Camp Forsyth had essentially escaped the rising water. ${ }^{119}$ All told, Fort Riley suffered flood damage of more than $\$ 6$ million. Luckily, there were no fatalities at the post due to the extraordinary flooding. ${ }^{120}$

\footnotetext{
116 “Wind, Rain Lash Area," Junction City Union, 10 July 1951, 1.

117 “Worst Flood Is Feared," Junction City Union, 11 July 1951, 1.

118 "Rivers on a Rampage," Junction City Union, 11 July, 1951, 1; “Fear Heavy Flood Damage at Post," Junction City Union, 11 July 1951, 1.

119 "Flood to New Heights," Junction City Union, 12 July 1951, 1; “River Stages Falling," Junction City Union, 13 July 1951, 1.

120 “Fort Loss \$6,000,000," Junction City Union, 16 July 1951, 1.
} 


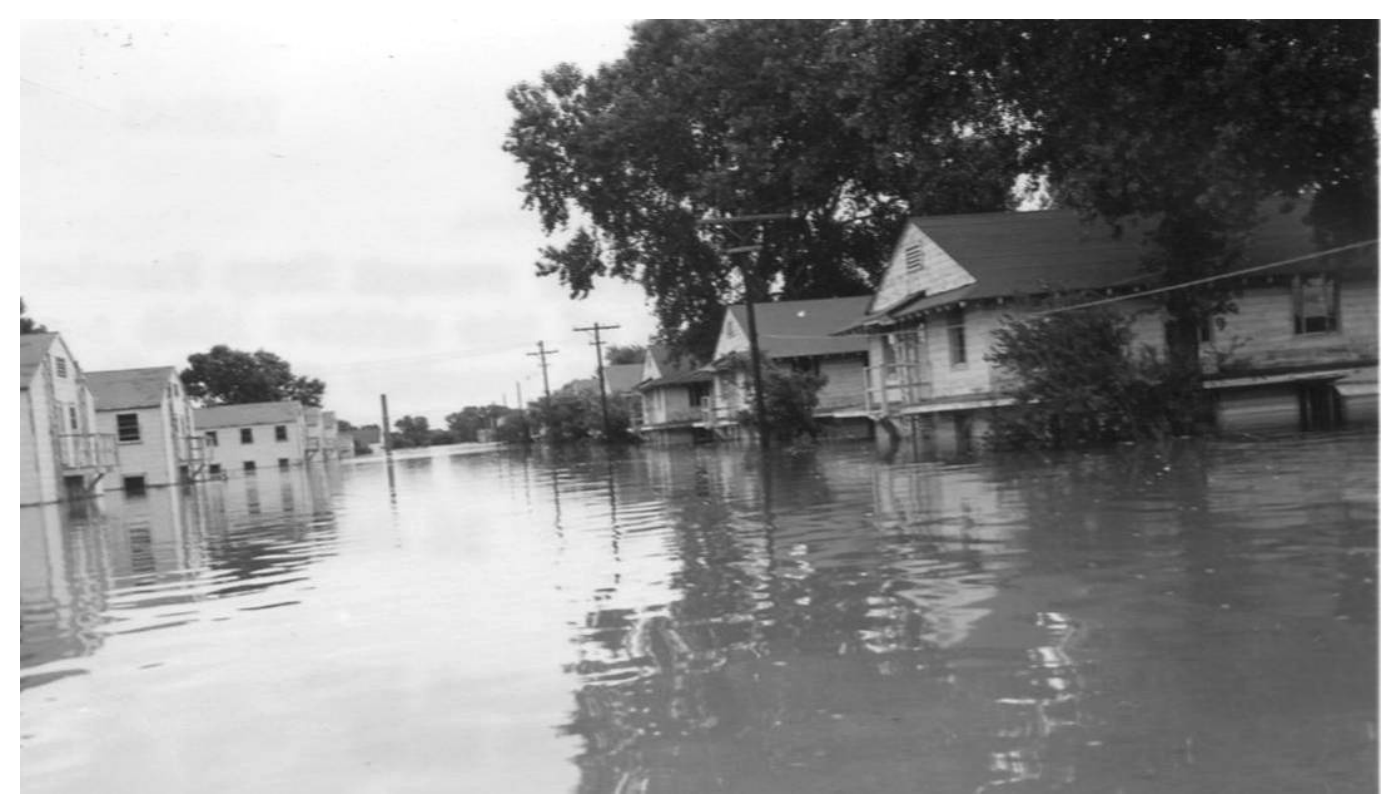

Figure 13. Camp Funston under water, July 16, 1951 (NARA).

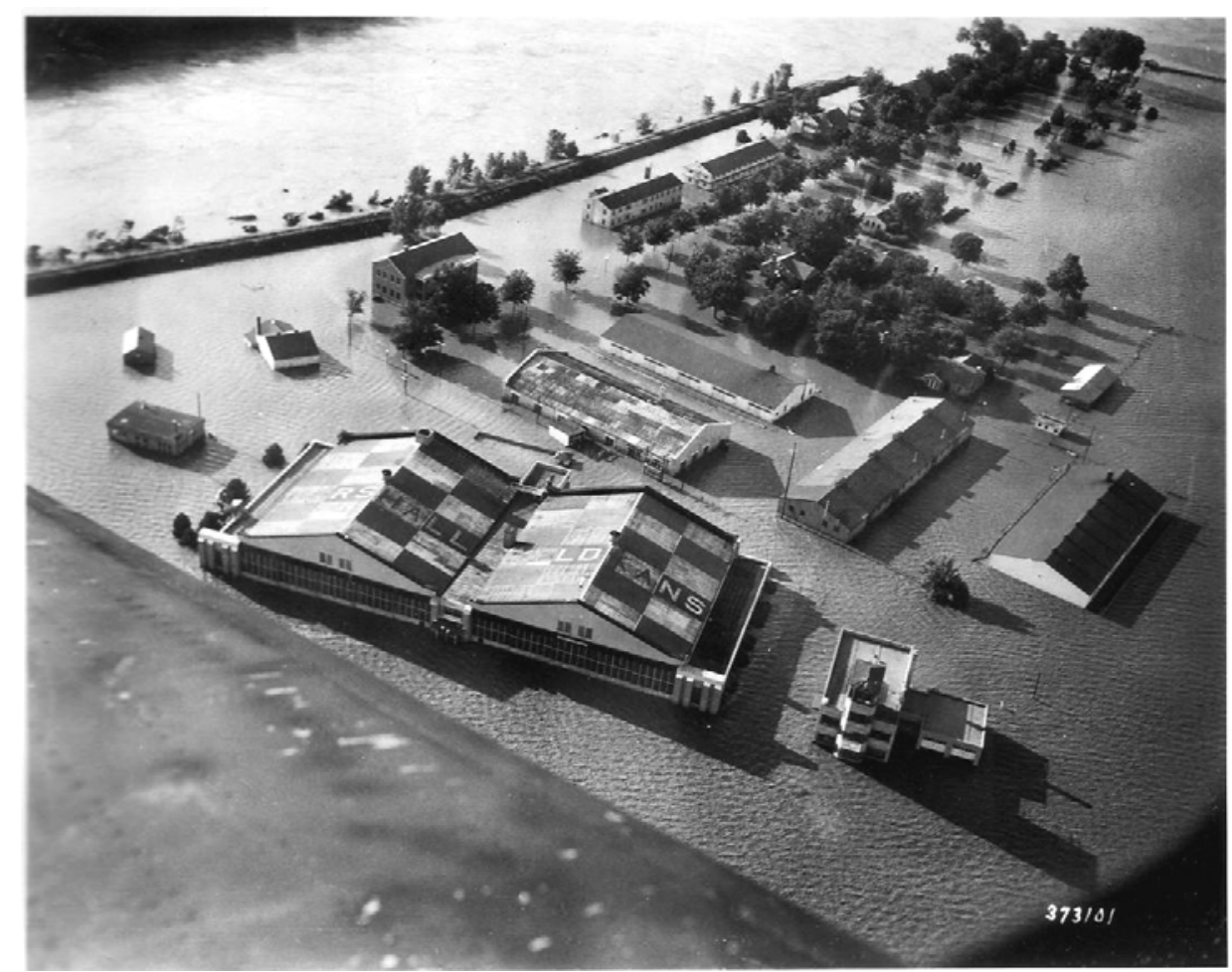

Figure 14. Marshall Field on July 16, 1951 (NARA).

On a more positive note, during the period under study, Fort Riley was visited by a number of distinguished military leaders and politicians including General Dwight D. Eisenhower, President Harry S. Truman, Secretary of War Robert P. Patterson, Commander of the Army Ground Forces General J acob L. Devers, 10th ID commander Major General Lester J . 
Whitlock, war hero General J ohnson M. Wainwright, and Kansas Governor Frank Carlson.

General Eisenhower made a "whirlwind three-hour visit" to Fort Riley on 15 February 1946 during a program where he visited a number of bases after winning the European theater in World War II. ${ }^{121}$ General Eisenhower arrived in his plane, the Sunflower 11, a C-54 Skymaster. After leaving Fort Riley, he visited his sister-in-law, Mrs. Roy Eisenhower and his nephew and nieces in J unction City and later his brother, college president Milton Eisenhower, at Kansas State College in Manhattan, and finally his mother Mrs. Ida Eisenhower in Abilene. ${ }^{122}$ He would return to Fort Riley several times in the coming years.

To honor one of Fort Riley's own, a number of distinguished visitors attended a ceremony on 4 April 1946 dedicating its Academic Building to the World War II hero, General George S. Patton, Jr., who died the previous December. Patton had graduated from the Cavalry School's mounted service course in 1914 to 1915, and also had been director of instruction at the school from 1937- 1939. ${ }^{123}$ The dedication of "Patton Hall" was broadcast nationwide with a tribute from President Harry S. Truman who sent a telegram praising Patton as a "brave and gallant fighting man." 124 Mrs. Patton was on hand to unveil the letters across the building's entrance. Secretary of War Robert Patterson, General J acob Devers, and Major General I.D. White, commander of the Fort Riley Cavalry School, attended the event along with over 5,000 others. ${ }^{125}$ The native stone building was completed in 1940 to house the academic division and library of the Cavalry School.

President Truman stopped at Fort Riley during a railroad whistle-stop on 20 September 1948 while campaigning for re-election. His campaign train stopped at J unction City and he was greeted by a crowd of 6,000- 7,000

\footnotetext{
121 “General 'Ike' Visits Riley: Army Chief of Staff Makes Three Hour Inspection At Post," Junction City Union, 15 February 1946, 1.

122 lbid.

123 "In Tribute to Patton: Secretary of War Praises late General at Colorful Ceremony Dedicating Patton Hall at Fort Riley," Junction City Union, April 4, 1946, 1-2.

124 “Truman Pays Tribute,” Junction City Union, 4 April 1946, 1.

125 "Fort Riley to Honor Memory of Gen. Patton," Junction City Union, 16 March 1946, 1; "Ready for Dedication: Secretary of War, Robert P Patterson to Arrive at Fort Riley Today, " Junction City Union, 3 April 1946, 1.
} 
people while he spoke from the rear platform of his train. ${ }^{126}$ After commenting that he had never given a political speech on Sunday, he proceeded to talk about his training at Fort Riley, "I came to Fort Riley to train as a field artilleryman. Sometimes they tried to make a cavalryman out of me, but they didn't succeed." 127

However diverting the appearance of these famous individuals was, the focus for continued utilization of Fort Riley centered on the constant need for training new soldiers and continuing the education of current troops. Having a prestigious background in military education through its Cavalry School, Fort Riley shifted emphasis after World War II to infantry and thus continued its role as one of the Army's premier training and educational centers.

\subsubsection{Basic infantry training}

Even though World War II was over, there was still a need to retain an Army, even if on a much-reduced scale. Recruit training continued to supply soldiers not only to U.S. installations, but also supplied the necessary forces for post-war operations in Europe and J apan. Post-war reorganization and swiftly changing manpower needs resulted in several organizations stationing and withdrawing from Fort Riley in a short amount of time.

On 20 J anuary 1946, it was announced that Replacement Depot No. 3 at Camp Funston would be closed. The center had only been in operation for six months, but had processed and assigned 63,000 replacements to other units and installations. ${ }^{128}$

On 28 J une 1946, it was announced that, effective 20 J uly 1946, the Army Reception centers at Fort Leavenworth, Kansas, and Fort Snelling, Minnesota, were being transferred to Fort Riley. ${ }^{129}$ The new reception center was

\footnotetext{
126 "Recalls Days at Fort Riley: President Truman Comments on Training as Field Artilleryman," Junction City Union, 20 September 1948, 1.

127 lbid.

128 “Funston Depot Quits Jan. 20: Colonel Proctor Announces Termination of Replacement Depot," Junction City Union, 11 January 1946, 1.

129 “New Use for Fort Riley: Leavenworth and Fort Snelling Reception Centers To Be Moved Here," Junction City Union, 28 July 1946, 1.
} 
able to handle 2,000-2,500 men and had the effect of adding a regiment of officers to Camp Funston. 130

The new reception center opened 25J uly 1946, making it the only remaining reception center for the 5th Army. At the reception center, every day approximately 200 new recruits would arrive for processing and assignment to their companies. The average processing time was three to seven days. The center employed approximately 440 enlisted men, 45 enlisted women, 51 officers, and 50 civilian personnel. ${ }^{131}$ In October, the new separation center was co-located with the reception center.

On 24 J une 1948, President Truman signed a two-year selective service bill and a nationwide draft went into effect in September. Prompted by increased hostility from Russia towards U.S. troops in Berlin and general communist expansion pressures, the draft served to build up the military services to a strength of two million men. ${ }^{132}$ All these new soldiers needed training, and at Fort Riley the $10^{\text {th }}$ ID arrived to provide training for the draftees in the latter part of 1948. The main unit on post, the 10 ${ }^{\text {th }}$ ID was one of nine such training divisions in the U.S. Army. By late August, the 10th ID had set up operations in Camp Funston, which would become its permanent home at Fort Riley. ${ }^{133}$

In what would become a nearly annual occurrence, beginning in 1948 7,200 National Guard soldiers came to Camp Funston during August for two weeks of summer training. ${ }^{134}$ In the same manner, Fort Riley played host to an annual six-week summer training camp for Reserve Officer Training Corps (ROTC) students, also utilizing Camp Funston.

The receiving center at Fort Riley was also busy. On 10 August, the first group of 18-year-old enlistees under the new selective service act arrived for training at Camp Forsyth. The initial group of 200 was followed by approximately 1,000 more recruits each week. ${ }^{135}$ Upon arrival, recruits were

\footnotetext{
130 lbid.

131 “Reception Center Open,” Junction City Union, 25 July 1946, 1.

132 “Draft Measure Becomes Law," Junction City Union, 25 June 1948, 1, 3.

133 In a reversal of this trend, a little over a year later measures were put into effect to provide early release for some draftees, as the Army strength of 656,000 was deemed too high ("Discharges to Inductees," Junction City Union, 25 October 1949, 1).

134 "Guards are Due Sunday: Expect 7,200 Soldiers at Camp Funston for Summer Training," Junction City Union, 6 August 1948, 1.

135 “18-Year Olds to Post,” Junction City Union, 10 August 1948, 1.
} 
given indoctrination lectures, a haircut and shower, clothing, a physical examination, and a unit and barracks assignment. After a battery of tests, the recruits entered the basic combat training phase. For eight weeks, they learned how to take care of themselves in combat, in preparation for assignment to a troop unit. ${ }^{136}$

The training was for combat infantry replacements, to keep established units up to strength; most replacements went to Europe or the Far East. By the end of its first year at Fort Riley, the 10th ID had received, processed, trained, and shipped out 22,077 men, and the Division had reached a strength of 10,212 officers and men. ${ }^{137}$ In March 1949, basic training was extended to 14 weeks. The additional time was devoted to more weapons training and additional courses in Armed Forces organization, military justice, intelligence training, and safeguarding national security. ${ }^{138}$

The Korean War required a large troop buildup in the Army, with personnel called up by Selective Service and mobilization of National Guard and Army Reserves. Basic training was provided for soldiers replacing casualties in Korea, and returning troops were provided more specialized training. The U.S. military was caught off-guard by the invasion of South Korea; it had been actively reducing personnel numbers for the past six months. As a result, a number of initiatives were put in place during J uly 1950, but it would take nearly a year for the military to be at full strength again.

The first of these initiatives, enacted on 27J une 1950, was a law extending the president's power to draft young men for another year. It was estimated this would add 600,000 troops, nearly filling the gap between present strength $(1,370,000)$ to authorized strength $(2,005,882)$. 139 The need for increased strength became more acute by $30 \mathrm{~J}$ une, when President Truman authorized the use of ground troops in Korea in response to the North Korean push to the south of Seoul. The first ground troops arrived the next day. The draft went into effect on 11J uly, with the first call for 20,000 men going out as soon as possible. ${ }^{140}$ The draftees were to be given

\footnotetext{
136 “Tells Plans For Tenth," Junction City Union, 5 November 1948, 1.

137 "Tenth Infantry Division, 10,000 Strong, Now Moving into Second Year on Its Mission of Training Young Men in Peacetime Army," Junction City Union, 9 November 1949, 8.

138 "Basic Training to be 14 Weeks," Junction City Union, 19 February 1949, 1.

139 “Draft Law Accepted," Junction City Union, 27 June 1950, 1; “Truman Could Call 600,000 Under Draft," Junction City Union, 28 June 1950, 1.

140 "The Use of Ground Units," Junction City Union, 30 June 1950, 1; “Troops in by Airlift," Junction City Union, 1 July 1950, 1; “Draft is in Motion Today," Junction City Union, 11 July 1950, 1.
} 
14 weeks of training, with the first troops being inducted by midSeptember. Active-duty soldiers were alerted on $20 \mathrm{~J}$ uly of possible deployment to the Far East, and the Armed Forces had been authorized to call up reserves and National Guard troops as necessary. The following day, the Army began mobilizing the National Guard. ${ }^{141}$ On 28 J uly, President Truman signed an executive order extending all current enlistments for an additional 12 months, and raised the draft call first to 50,000 and again to 100,000. By 4 August, the Army was calling up reservists for 21 months of service. ${ }^{142}$ Draft calls continued, and on 1 September, the president called for a total strength of 3,000,000 men by the following summer. By the time he made the announcement, there were already 75,000 men fighting in Korea. ${ }^{143}$ The draft calls through December yielded 210,000 enlistees; after this things began to slack off a bit as the Army had nearly doubled its strength by March 1951. ${ }^{144}$

One year after the invasion of South Korea, there were 1,841,000 more troops under arms in the United States military. ${ }^{145}$ It began to be plain to those in power that the long-term security of the United States would require a standing Army at a higher level of strength than had been contemplated, due to perceived continuing dangers from Russia. To that end, on $19 \mathrm{~J} \mathrm{une} \mathrm{1951,} \mathrm{President} \mathrm{Truman} \mathrm{signed} \mathrm{into} \mathrm{law} \mathrm{a} \mathrm{bill} \mathrm{that} \mathrm{provided} \mathrm{a}$ foundation for universal military training by lowering the draft age to $18^{1 / 2}$, requiring 24 months of service, and continuing the draft until $1 \mathrm{~J} \mathrm{uly,}$ 1955. ${ }^{146}$

According to 10th ID officers, the division could quickly expand to a total of 14,000 men if necessary. The new trainees would take the standard 14week basic combat training, including weapons training (Figure 15), marches and bivouacs, physical training, dismounted drill, map reading, tactical training, and guard duty. ${ }^{147}$ After completing the training, soldiers

\footnotetext{
141 "To Train for 14 Weeks," Junction City Union, 12 July 1950, 1; "Call Reserves to Duty," Junction City Union, 20 July 1950, 1; "Mobilization at a Glance," Junction City Union, 20 July 1950, 1; "The National Guard Called," Junction City Union, 21 July 1950, 1.

142 “Boost Draft by 80,000," Junction City Union, 28 July 1950, 1; “Army to Call Reservists," Junction City Union, 4 August 1950, 1.

143 “Ask 3 Million Man Force," Junction City Union, 2 September 1950, 1.

144 "Ease Off on Mobilization," Junction City Union, 27 October 1950, 1; “Double U.S. Armed Force," Junction City Union, 21 March 1951, 1.

145 “Army Is Nearing Planned Strength," Junction City Union, 26 June 1951, 9.

146 “Hail Signing of Draft Law," Junction City Union, 19 June 1951, 1.

147 “Can Handle Draftees," Junction City Union, 12 July 1950, 1, 4.
} 
either continued their training at a specialty school or were assigned to a unit. The 10th ID was operating service schools for auto mechanics, supply and general clerks, bandsmen, and potential non-commissioned officers. 148

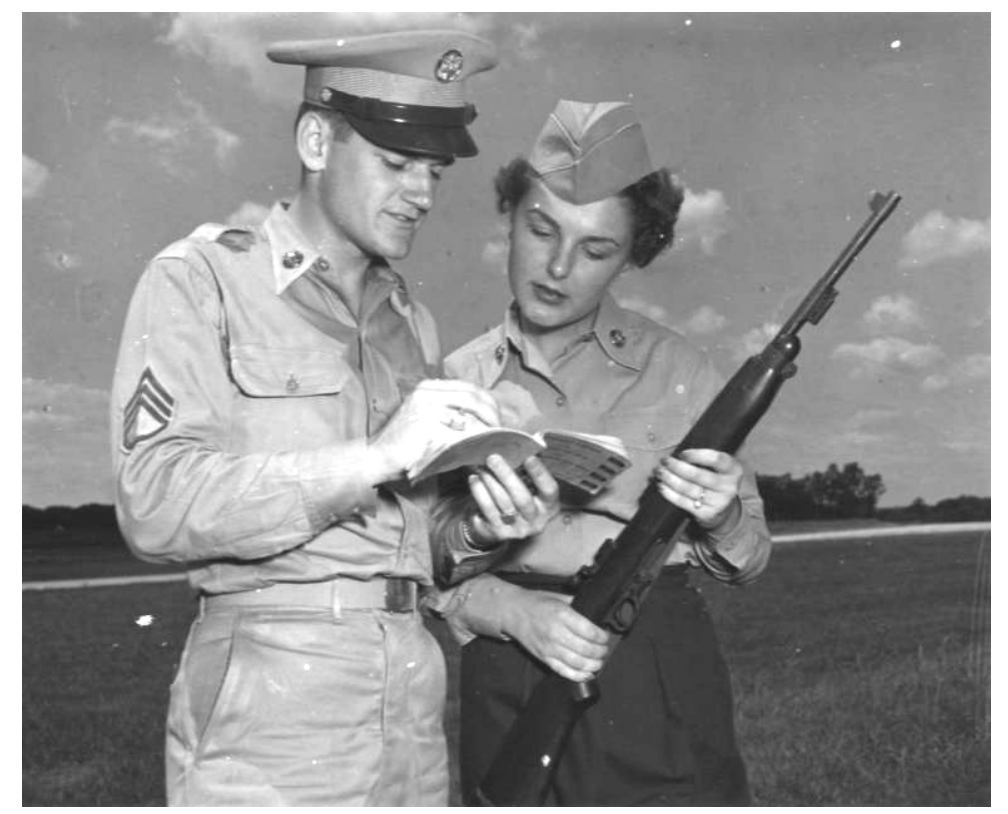

Figure 15. WAC receives a high score at the rifle range, 1951 (NARA).

The necessary rapid mobilization entailed preparing the four existing training centers at Fort Riley, Fort Knox, Fort Ord, and Fort Dix. Additionally, eleven advanced replacement centers for quickly producing specialized solders were set up at those four training centers and also at Fort J ackson, Camp Chaffee, Camp Breckinridge, Fort Leonard Wood, and Camp Gordon. At the replacement centers, the trainees received six weeks of basic training and eight weeks of training in their specialties. ${ }^{149}$ The first group of draftees to undergo this training arrived at Fort Riley in the early hours of 19 August 1950. The first regular Army draftees were joined a few weeks later by the initial complement of National Guard units that were taken to Camp Forsyth to start four months of training. ${ }^{150}$

\footnotetext{
148 Ibid., 4.

149 "Tenth Division to Receive Draftees," Junction City Union, 20 July 1950, 1: “Army Will Open 11 Training Centers," Junction City Union, 17 August 1950, 3; "First Draftees Meet the Army," Junction City Union, 19 August 1950, 1.

150 “First Draftees Meet the Army," 1; “First Guard Unit Arrives," Junction City Union, 8 September 1950, 1.
} 
Approximately one year into the Korean conflict, the Army resumed a sixteen-week basic training cycle for recruits. Two weeks of training had been dropped during the rapid troop buildup of the previous fall. As troop quotas were being met both at home and in Korea, however, the longer training period returned. At Fort Riley, the extra time was allotted to more weapons training and a course on Army traditions. ${ }^{151}$

Near the very end of the conflict, Fort Riley was selected as the home of a new 5th Army Reception Station for new recruits, located at Camp Forsyth. The new facility replaced the Army Officer Candidate School at the post, employed a staff of about 500, and handled 400-600 inductees a day. ${ }^{152}$ The reception center originally had a dual purpose: processing of new inductees and serving as a reassignment station. For the latter mission, personnel returning to the United States from foreign duty (other than the Far East Command), and returning Far East Command combat personnel were paid, had a physical check, and received assignment to a new duty station. The reassignment activity was inactivated 1 November 1953. ${ }^{153}$

In 1951, the U.S. Senate's Preparedness Subcommittee of the Committee on Armed Services conducted an investigation of the Preparedness Program at Fort Riley. This was part of a wider study of military preparedness in the wake of the scrambled effort to meet the manpower and training challenges at the onset of the Korean War. During a February 1951 visit to Fort Riley, investigators determined the training was very satisfactory, and that the facilities and programs supporting the mission of indoctrination and basic training were "well-designed and effectively operated."154 The 10th ID was operating a receiving and processing center for new recruits arriving directly from an induction center. After a series of presentations covering life during basic training, chaplain and Red Cross services, military courtesy, personal conduct, and care of equipment, the recruits began the processing component. For five days, they underwent physical and intellectual examinations to determine the job classification best suited to

\footnotetext{
151 “Army to Resume 16 Weeks Basic Training," Junction City Union, 19 June 1951, 1; “Two Weeks Added to Training Cycle," Junction City Union, 6 July 1951, 1.

152 “One of Nation's Top Military Posts," Junction City Union, Centennial Edition, 24 June 1953, 1; “Reception Center To Be Expanded," Junction City Union, 20 July 1953, 1.

153 “Reception Center To Be Expanded," Junction City Union, 20 July 1953.

154 U. S. Senate, "Investigation of the Preparedness Program, Twenty-Fourth Report of the Preparedness Subcommittee of the Committee on Armed Services, United States Senate: Fort Riley, Kans.," (Washington, DC: GPO, 1951), 1.
} 
their skills. At the end of those five days, the recruits began the regimen of basic training; some remained at Fort Riley for this (Figure 16), while some were sent to other installations. ${ }^{155}$

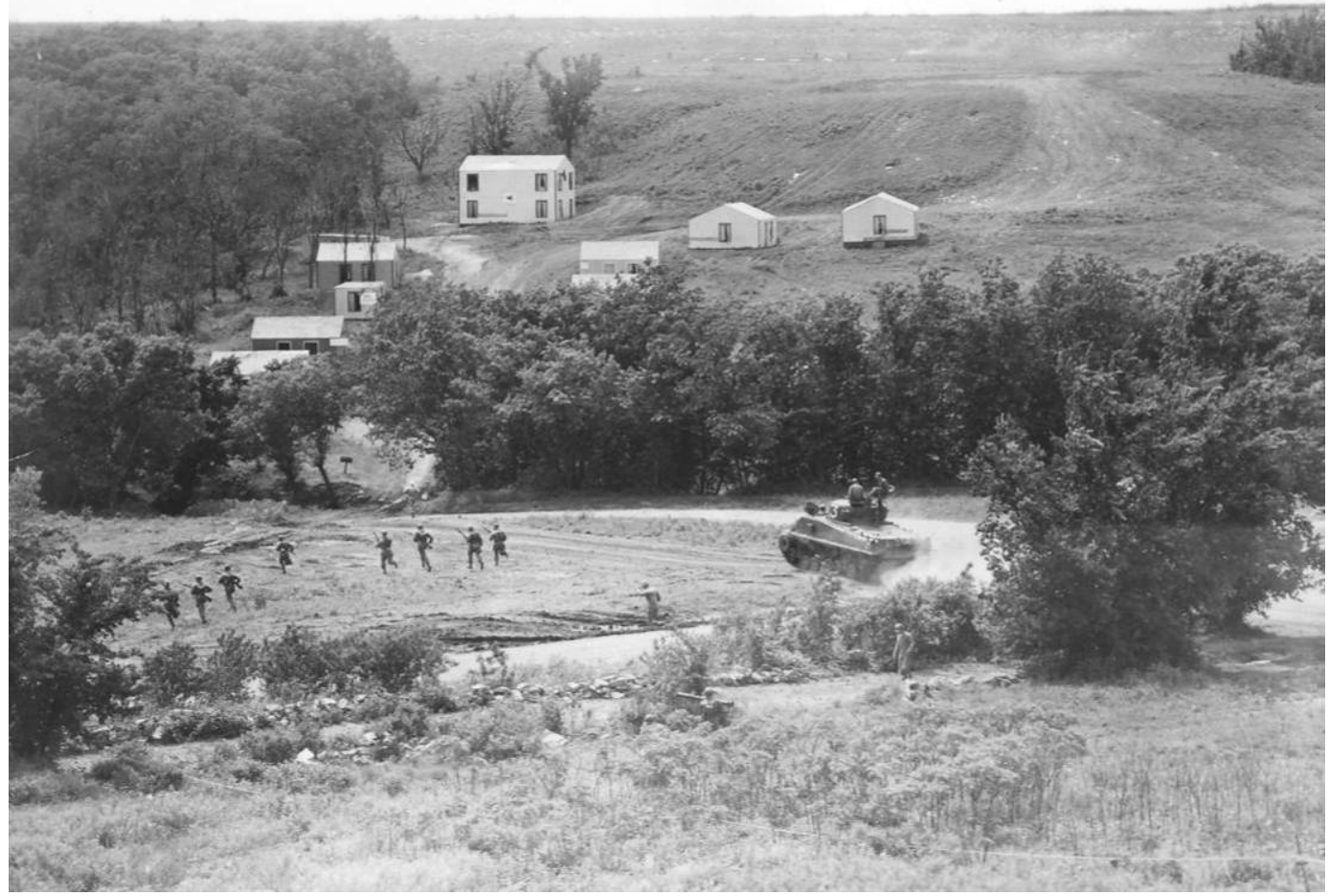

Figure 16. Tank supported 10th Division trainees move on an enemy held town in urban training exercises, 1952 (NARA).

Basic Combat Training was provided by three basic training regiments of the 10th ID, with a combined capacity of 8,730 trainees. The training followed that set up by Army Field Forces, and was conducted in six- and fourteen-week cycles (Figure 17). 


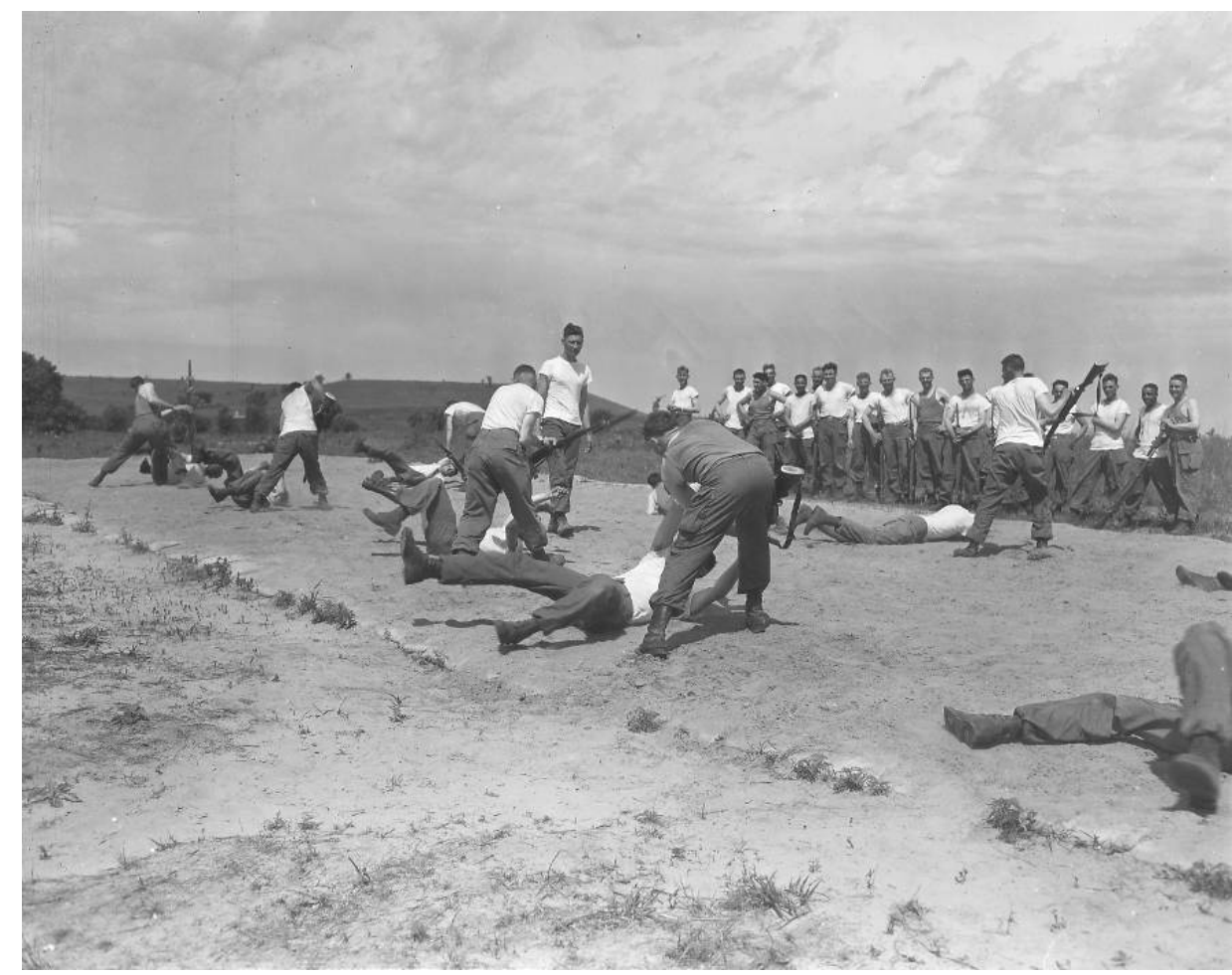

Figure 17. Basic combat training, 1952 (NARA).

After six weeks of basic training, soldiers destined for specialist work were sent to the specialist or service schools. The 10th ID itself operated several common specialist schools, including those providing training for typists, cooks, bakers, supply clerks, motor mechanics, and truck drivers. ${ }^{156}$ By March 1951, a Chemical Biological Radiological Warfare course was running at Fort Riley. The 19 hours of training included information on the types of chemicals used by the Army, their capabilities, how to detect them, and how to protect oneself from them. ${ }^{157}$

The remaining trainees received another eight weeks of instruction in light and heavy infantry weapons. Weapons training ranges were nearly all within walking distance, and used in rotation, with one unit firing while another observed or received a relevant lecture. At the end of the cycle, trainees took a "merit stakes test" that involved a cross-country exercise with stations where they would be given a quiz geared to actual combat activities, all to judge individual proficiencies. ${ }^{158}$

\footnotetext{
156 Ibid., 1.

157 "Students at Post Taking Course in Chemical Warfare," Junction City Union, 26 March 1951, 7.

158 U. S. Senate, "Investigation of the Preparedness Program," 3-4.
} 
To assist in providing a full measure of realism to the training, a specialized unit of soldiers based at Fort Riley took role-playing to a new level. Organized in 1948 as part of the Ground General School, the Aggressor Cadre served as the maneuver enemy for the U.S. Army (Figure 18). Constant research into enemy tactics resulted in an aggressor force with its own uniforms, skills, language (Esperanto), and strategies. Using military terms in various languages, the Aggressor forces organized themselves as a hybrid of many foreign armies, drawing heavily upon the German and J apanese. ${ }^{159}$ The force also served to provide Army intelligence troops with experience dealing with "enemy" prisoners who were interrogated in their native tongue, and their order of battle learned and understood. 160

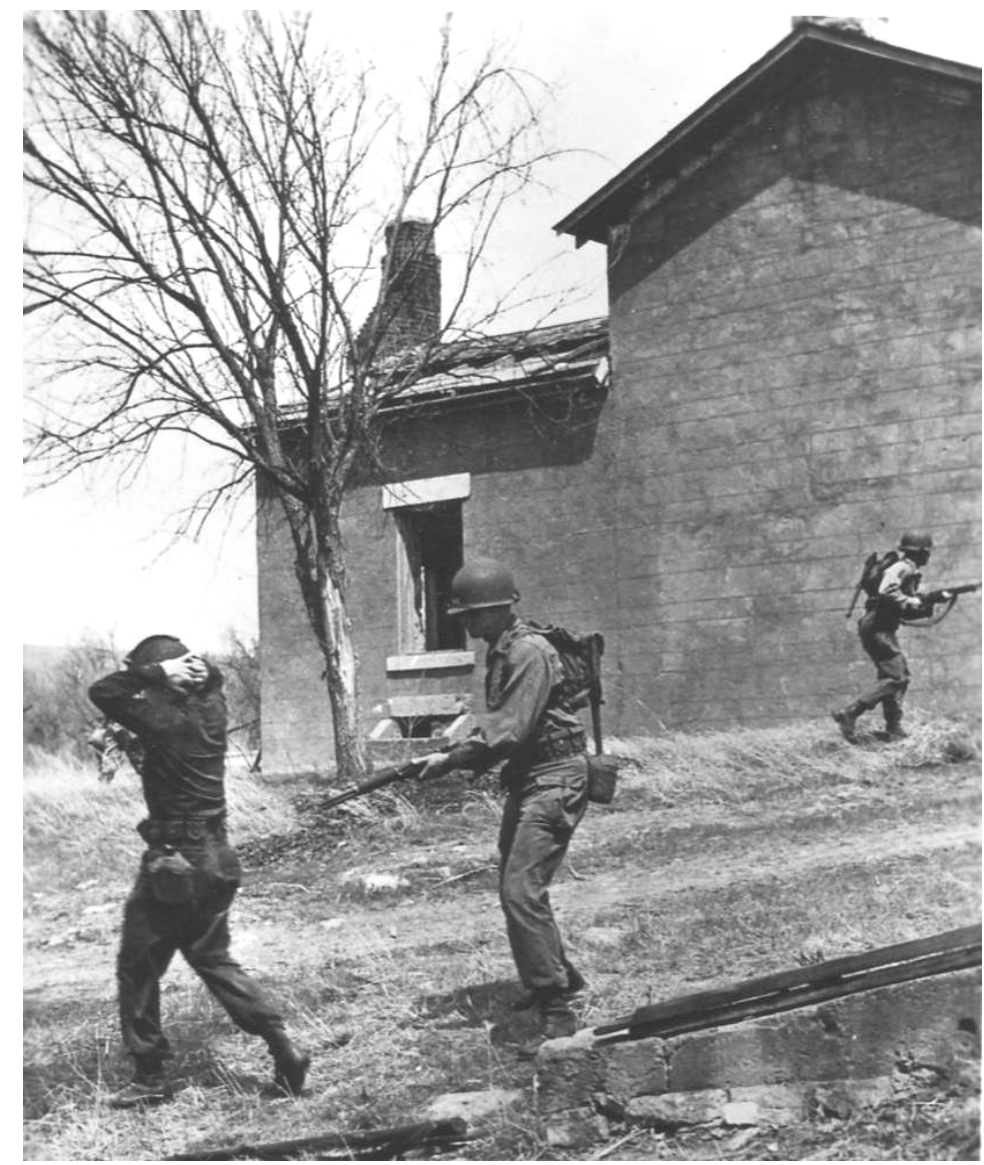

Figure 18. An Aggressor soldier being led away by an American force, 1950 (NARA).

The Aggressor Cadre participated in training exercises across the country, as well as at Fort Riley. For example, in February and March 1949, they

\footnotetext{
159 "Fort Riley and Marshal Field Having Leading Roles in Maneuvers," Junction City Union, 11 May $1948,2$.

160 lbid.
} 
played their role during Operation Portrex, a joint amphibious-airborne exercise based around Vieques Island near Puerto Rico. The largest exercise since the end of World War II, Operation Portrex involved 80,000 soldiers, sailors, and airmen in testing new weapons and techniques for assault or defense. ${ }^{161}$ After the Korean War, in 1953 the cadre constructed large bunkers in the hills on Fort Riley that were modeled after an enemy position found outside Seoul, Korea. Trainee companies had to attack and conquer the bunkers by routing the entrenched aggressor troops. ${ }^{162}$

\subsubsection{Military education training}

The Cavalry School was still in operation at the end of World War II. In J anuary 1946, the program of instruction was expanded, primarily to include the Intelligence School which served to train officers and enlisted men in new intelligence methods gleaned from World War II experience. Classes in radio operation and repair, and motor mechanics were also offered. The focus, however, remained on cavalry operations, both horse and mechanized. 163

Later in 1946, the era of horse units ended with the acknowledgement of the supremacy of motorized transport for military needs. An October announcement publicized the decision to radically alter the educational training offered at Fort Riley, with the relocation of the Ground General School from Fort Benning, Georgia to Fort Riley. Functions of the Cavalry School not involving animals were transferred to Fort Knox, Kentucky. The relocation of the school was part of an Army plan for reorganizing six Army schools in an effort to meet the goal of eventually having all ground forces air-transportable.

Factors contributing to the choice of Fort Riley included the reservation's size and good climate for training, its central location, and the physical plant already in place. The school was expected to have a capacity of 6,000 students, upping the Fort Riley population to nearly 10,000. As part of the plan, the Ground General School operated an Officer Candidate School for

\footnotetext{
161 "Post Units to Maneuvers," Junction City Union, 12 January 1949, 1.

162 "Colonel Comfort to Aggressor Exercises," Junction City Union, 25 February 1953, 1; "Bunkers,

Trenches, Add Realism to Training at Fort," Junction City Union, 14 February 1953, 6.

163 “Broaden Courses at Cavalry School," Junction City Union, 26 January 1946, 1.
} 
the entire Army, with students from all the armed services. The 26-week course of study would provide two graduating classes per year. ${ }^{164}$

On 31 October 1946, the Cavalry School was closed, but the Ground General School opened the next day, maintaining the post's unbroken string of service schools stretching back to the late $19^{\text {th }}$ century. Relocated from Fort Benning, Georgia, the mission of the Ground General School was to provide training to newly commissioned officers in basic military subjects, provide an Army Officer Candidate Course, and train officers and enlisted men as intelligence specialists. 165 The Ground General School offered a seventeen-week branch immaterial course to provide newly commissioned officers with the knowledge to undertake their duties at the basic level. The first class of 183 officers began the course on 14 August 1947, nearly all from the most recent U.S. Military Academy graduating class, accompanied by five Latin American Army officers, two U.S. Navy officers, and three other Army officers. ${ }^{166}$

Re-designated the Army General School in 1950, its instruction tasks continued as before. Additional missions included developing tactics and techniques for the Aggressor Cadre and serving as the unit's home. Several distinct educational entities were part of the Army General School: the Intelligence Division, the Department of Resident Instruction, and the Department of Non-Resident Instruction. ${ }^{167}$

The Intelligence Division provided instruction for officers and noncommissioned officers in "general intelligence, aerial photo interpretation, order of battle, interrogation of prisoners of war, technical intelligence coordination, censorship, and strategic intelligence research and analysis."168 As the only school of its type, instruction was not limited to Army personnel, but included Navy, Marine Corps, and Air Force students.

The Department of Resident Instruction supervised all of the Army General School training conducted on post. The Department of Non-Resident

\footnotetext{
164 “A New Fort Riley Era," Junction City Union, 21 October 1946, 1.

165 “Army General School Nears Its 64th Year at Fort Riley," Junction City Union, 24 February 1955, 4;

"Fort Riley: Its Historic Past," (Washington, DC: Center for Military History, Vertical File: "228.03 HRC

331 Posts - Riley, Fort," ca. 1973), 12.

166 "Praise for Army Schools," Junction City Union, 14 August 1947, 1, 6.

167 "Army General School Is The Successor to Cavalry School," Junction City Union, 24 June 1953, 1. 168 Ibid.
} 
Instruction prepared and distributed instructional materials on intelligence and basic military subjects as correspondence courses to over 30,000 Army and civilian personnel every month. More than 130 different courses were offered by mail, with the Department's staff grading work and sending out marks. In-house production needs resulted in the Division having a printing plant, bindery, drafting and art sections, storage areas, and a photo laboratory. ${ }^{169}$

The first class of the Officer Candidate School had eighty-five students and began on $30 \mathrm{~J}$ une 1947. Camp Forsyth had been cleaned, and the service club, theatre, swimming pool, baseball diamond and running track had been opened. The camp had received little use since the Cavalry Replacement Training Center closed approximately one year earlier. ${ }^{170}$ Class size continued to grow, reaching a graduating class of 150 in August 1949. Subjects covered during their attendance included "communications, tactics, small arms and artillery weapons, map reading, photo interpretation, company administration, leadership, and physical development." 171

The outbreak of war in Korea affected Fort Riley in several ways. In addition to increasing the basic training capability, the Army also ramped up efforts to graduate students from various Army schools. Beginning in October 1950, the Army General School at Fort Riley began additional classes of the Officers Intelligence course, the Enlisted Intelligence course, and the Officer Candidate School. This was followed in March 1951 with the Army's decision to double its training program in four field forces schools, including the Army General School. Fort Riley officials noted at the time that the Intelligence School was operating at full capacity, and the Officer Candidate School had doubled in enrollment since the start of the Korean War. This was particularly impressive as two other Officer Candidate Schools at Fort Benning and Fort Sill had opened in the meantime. ${ }^{172}$ By the time the Officer Candidate School closed in 1953, it had a record of over 5,000 graduates. ${ }^{173}$

\footnotetext{
169 lbid.

170 “First AOC Class Opens," Junction City Union, 30 June 1947, 1.

171 “Largest AOC Class To Graduate Friday," Junction City Union, 31 August 1949, 1-2.

172 "Army General School Is Growing Rapidly," Junction City Union, 10 October 1950, 1; “Army Will Enlarge Field Force Schools," Junction City Union, 16 March 1950, 1.

173 "The Life of Riley," (San Diego: Military Publishers, 1974), Vertical File, Center for Military History, Washington, D.C.
} 


\subsubsection{Post-WWII Air support for Fort Riley at Marshall Field}

The creation of the Air Force in 1947 resulted in the establishment of Army aviation as a separate entity. Over the next several years, the duties assigned to both organizations were debated and refined. In 1949 and 1950, a series of discussions led to Army aviation being defined by the weight of aircraft, with limitations placed on both fixed and rotary wing craft. ${ }^{174}$ The Korean War placed new demands on both Army aviation and the Air Force, resulting in a new series of discussions during 1951 and 1952. A Memorandum of Understanding was put into place on 4 November 1952 that retained a maximum weight limit on fixed wing craft (5,000 pounds), but removed the restriction from rotary-wing aircraft. ${ }^{175}$ As the Korean conflict ably demonstrated the utility of helicopters for moving both troops and cargo, Army aviation was in a position to rapidly advance the role of rotary-wing aircraft. The helicopter's growing importance required new training and organization. The Transportation Corps took over logistical support for Army aviation in August 1952, concurrently with the establishment of the first transportation helicopter companies. The Army Aviation School was begun at Fort Sill, Oklahoma in 1953. 176

Post-war reductions and organizational changes resulting from the end of World War II created a shifting roster of units assigned to Marshall Field, with 4 different units rotating through in a few short months. In November 1945, the $2^{\text {nd }}$ Composite Squadron was inactivated and replaced by Detachment B, 69th Reconnaissance Group. Then in 1946, Detachment B, $69^{\text {th }}$ Reconnaissance Group was transferred and replaced by the $72^{\text {nd }}$ Liaison Squadron, which, in turn, was inactivated and its personnel absorbed by the 167th Liaison Squadron, reporting from Fort Sill. The 167th Liaison Squadron was re-designated the $163^{\text {rd }}$ Liaison Squadron in October 1946. ${ }^{177}$

A course in aerial observation for cavalry officers was instituted in March 1946 with 42 officers enrolled. The aircraft utilized were flown by pilots of the 72nd Liaison Squadron based at Marshall Field, and the students learned air-to-ground communication, radio procedure, air observation in

\footnotetext{
174 Richard P. Weinert, Jr., A History Of Army Aviation - 1950-1962, (Fort Monroe, Virginia: Office of the Command Historian, U.S. Army Training and Doctrine Command, 1991), 267.

$175 \mathrm{Ibid}, 268$.

176 Ibid.

177 Joseph P. McGinley, “U.S. Army and Air Force Wings Over Kansas, Part Two" The Kansas Historical Quarterly, Vol. XXV, Autumn 1959, 3:344.
} 
the adjustment of artillery fire, and the use of aerial photos, charts, and photographic equipment. ${ }^{178}$ Support for the Ground General School remained the major mission of the airfield, with personnel servicing and maintaining transient aircraft and facilitating special units working with the school. ${ }^{179}$ The first assignment of helicopters at Fort Riley occurred in 1947 with the acquisition of six by the 163d Liaison Squadron. 180

The next major change for the airfield was a large one, as it became an Air Force Base in August 1948, but continued the same mission of supporting the Ground General School. In April 1949, however, the base went to "housekeeping" status, as light aviation detachments of the Ground General School and the 10th ID took over many of the flying missions. ${ }^{181}$ But by September, activity levels increased as the Tenth Air Force established the Central Instrument Flying School at Marshall Air Force Base with an annual roster of 400 students. Each class of 20 students underwent a twoweek refresher course. The training cadre numbered 12 officers and 31 enlisted men and was housed at the base along with the students. 182 Eight instructors utilized ten B-25s, later replaced with C-45s, and trained 86 pilots before the school was moved to Selfridge Air Force Base in March 1950. ${ }^{183}$

By the beginning of 1950, the Air Force was reconsidering the need for Marshall Air Force Base. Contributing to this decision were the hills surrounding the base that hindered the use of the larger and higher speed planes. Also, although the base had two 4,500 feet-long concrete runways that could accommodate $\mathrm{C}-54$ and C-82 transports, the runway surfaces were not hardened enough to provide long-term support. ${ }^{184}$ The Air Force returned the facility to the Army on 1J une 1950.

The Army Aviation Detachment at Marshall Field served as the center for major repairs and overhauls to an area of 12 states, covering all 150 of the 5th Army's aircraft and National Guard planes. Aircraft types maintained

\footnotetext{
178 "Aerial School At Fort Riley," Junction City Union, 1 March 1946, 1.

179 "Fort Riley Ideally Located for Carrying Out Activities," Junction City Union, 9 November 1949, 11.

180 McGinley, “U.S. Army and Air Force Wings Over Kansas, Part Two," 3:344.

181 "Marshall Field From the Air," Junction City Union, 9 November 1949, 3.

182 "New Unit to Air Base," Junction City Union, 31 August 1949, 1.

183 McGinley, “U.S. Army and Air Force Wings Over Kansas, Part Two," 3:345.

184 "Fort Riley Ideally Located for Carrying Out Activities," Junction City Union, 9 November 1949, 11.
} 
for the 5th Army included L-5's, L-16's, L-17's, and H-13 helicopters. 185 New equipment required new training, and in 1952, Marshall Field served as the receiving and disbursing point for the new Hiller Helicopter. Shipped directly from the plant in Palo Alto, California, the crew at Fort Riley assembled, tested, and flew the craft to their assigned bases. During the assembly and testing phase, a Hiller representative instructed the Marshall Field crew and mechanics from five other installations in maintenance and knowledge of the craft's special features. ${ }^{186}$

\subsubsection{Postwar construction at Fort Riley}

New construction at Fort Riley during the years under study was constrained by a lack of funding that affected the military nationwide after World War II. Much of the physical plant work that did occur involved remodeling older buildings to convert them to most-needed uses. Even the implementation of the 1948 draft did not result in new construction, as there were idle facilities that were turned to this purpose. A special edition of the J unction City Union on November 9, 1949 provided a snapshot of the physical development of the post to that point: 187

The main post, or Fort Riley proper, is the permanently constructed section of the Center. It contains administration buildings, barracks, family quarters for officers and noncommissioned officers, an officers club and mess, NCO clubs, service clubs, a nine hole golf course, a grade school, library, chapels, mess halls, technical maintenance shops and warehouses among it facilities. Among improvements completed in the past year are a dial telephone exchange, a new Center Headquarters building facing on US Highway 40, and additional family quarters converted from barracks buildings. A new field house is at present under construction.

Camp Forsyth contains 210 barracks, 50 mess halls, officers quarters, five dispensaries, a dental clinic, warehouses, and administration and headquarters buildings. Its facilities for off duty activities include a theater, with a seating capacity of 1,000;

\footnotetext{
185 “Army Finds Need For Marshall Field," Junction City Union, 20 July 1950, 3.

186 "Army Helicopters Will Be Assembled Here, Then Flown To New Assignments," (Fort Riley) Guidon, 20 August 1952, 5.

187 “Fort Riley Ideally Located for Carrying Out Activities," Junction City Union, 9 November 1949, 11.
} 
a service club, a swimming pool with a modern filtering system, a skeet range, a golf driving range, indoor and outdoor boxing arenas, tennis courts, football fields, two chapels and a guest house. Camp Funston was rebuilt in 1940 and now contains 890 buildings on its 2100 acres.

With a rapidly growing population, there was a sharp increase in the need for housing, with a shortfall of 1,300 sets of family quarters at Fort Riley which, at that time, had only 483 sets of quarters (217 officer and 266 enlisted). ${ }^{188}$ The conversion of primarily World War II temporary buildings into installation family housing got underway through the FY 1947 Military Establishment Bill. Contained within was a proposed conversion project for Fort Riley, and authorization was subsequently received from Washington for conversion of 172 housing units on post. ${ }^{189}$ Thirty-seven buildings in Camp Whitside and six buildings in the Women's Army Corps (WAC) area just east of the old Station hospital were converted into apartments for 172 families from temporary type barracks. 190 Building materials salvaged from the dismantling of 205 temporary "theater of operation" buildings were used in the conversion of the 43 housing units. The project was bid at $\$ 544,000$, and completed by October 1947, marking Fort Riley's first permanent housing construction since the beginning of World War II. 191 Then in J une 1947, Mont. J . Green, a contractor in Manhattan, Kansas was awarded a $\$ 500,000$ contract to convert an additional 46 barracks in the Whitside area into 184 apartment units within 200 working days. ${ }^{192}$ The buildings available for conversion were not limited to barracks, as old stable guard shacks were also pressed into service as 17 residences, mostly on the Main Post. ${ }^{193}$ A trailer center that could accommodate 28 trailers was installed in the former National Guard areas to the rear and west of the hospital buildings. 194

\footnotetext{
188 “Heavy Housing Need," Junction City Union, 16 July 1948, 1.

189 U.S. House, Committee on Appropriations, Military Establishment Appropriation Bill for 1947: Hearing Before the Subcommittee on the Committee on Appropriation, 79 ${ }^{\text {th }}$ Cong., $2^{\text {nd }}$ sess., (Washington D.C.: G.P.O., 1946).

190 “Open Bids for Work at Post," Junction City Union, 28 April 1947, 1.

191 "Will Ask Bids of Barracks Conversions," Junction City Union, 13 March 1947, 1; "Open Bids for Work at Post," 1; "First Apartments at Post in October," Junction City Union, 15 September 1947, 1; “Approve Fort Housing Plan," Junction City Union, 9 December 1946, 1.

192 “To Start on Fort Housing," Junction City Union, 5 June 1947, 1.

193 “Fort Riley News," Junction City Union, 5 August 1948, 3.

194 Ibid.
} 
Another conversion project during 1949-50 involved labor by Fort Riley soldiers to reconfigure barracks into apartments. The Post Housing Project utilized 183 "soldier carpenters," and provided 334 more housing units to post families. At a cost of $\$ 850$ each, the housing was distributed across the installation, with 206 units at Forsyth, 86 at Funston, 16 at Whitside, and 26 at Marshall Field. 195

Within a fewyears, efforts were being made by the government to provide funds for new housing construction on military installations. These funds were somewhat limited, and strict new rules were put in place about the upper size limit of new quarters, restricting them to 1,080 square feet. 196

Construction of family housing units, barracks and utilities at Fort Riley was proposed in J anuary 1948 for an estimated \$826,300. The project included 44 sets of quarters, 20 for non-commissioned officers, 20 for officers and four for field-grade officers. ${ }^{197}$ By the time the project was funded in 1949 , the allowed cost had been reduced to $\$ 592,000$. When construction began, the average unit cost ran to $\$ 18,031$, so only 32 units were constructed in 1950. 198 The housing, Rim Rock Terrace, was designed as eight apartment blocks that contained four apartments each. The contract was awarded to Mont. J . Green of Manhattan, Kansas, at a cost of \$509,049. 199

An effort to provide adequate housing to military families without using government appropriations resulted in the passage of the Wherry Bill in 1949. The bill provided Federal Housing Authority (FHA) insured mortgages for military housing on military installations or on nearby land leased from the military. By providing mortgage insurance, developers and lending institutions were persuaded to create these housing developments without fear of monetary loss. Since these developments were built and financed by private enterprise, no government financing was required. The

\footnotetext{
195 “Army Building Teams Complete 344 Family Units at Riley,” Junction City Union, 27 July 1950, 12.

196 U.S. House, Committee of Conference, Construction at Military Installations, $80^{\text {th }}$ Cong., $2^{\text {nd }}$ sess., House Report 80-2141, (Washington, D.C.:GPO, 1948).

197 “Fort Riley Housing Bill to the House," Junction City Union, 13 January 1948, 1.

198 U.S. House, Committee on Appropriations, Military Functions, National Military Establishment Appropriation Bill for 1949: Supplemental Hearing Before the Subcommittee of the Committee on Appropriations, $80^{\text {th }}$ Cong., $2^{\text {nd }}$ sess., (Washington D.C.: G.P.O., 1948); U.S. House, Committee on Armed Services, Full Committee Hearings on H.R. 7008 and S. 2440 to Authorize Certain Construction at Military and Naval Installations, and For Other Purposes: Hearings Before the committee on Armed Services of the House of Representatives on Sundry Legislation Affecting the Naval and Military Establishments 1950, 81 st Cong., $2^{\text {nd }}$ sess., No. 180, (Washington D.C.: 1951), 5649.

199 “Mont Green to Build Apartments at Post," Junction City Union, 18 June 1949, 1.
} 
loans were federally insured. The builders received rent from the soldiers which was used to repay the mortgage. The government provided 75-year leases to the builders for the development lands.

Fort Riley received approval for a Wherry housing project containing 400 rental units on $24 \mathrm{~J}$ une 1950 . The $\$ 3.5$ million project was sited on fortyfour acres north of Anzio Road, between U.S. Highway 40 and Camp Forsyth. 200 The 400 units were built by a corporation formed for the work, Fort Riley Apartments, Inc., of Wichita, with Builders Construction, Inc., of Wichita as the general contractor. The housing was for both officers and NCOs, and consisted of sixty separate buildings with a combination of row houses and duplexes (twenty one-story and forty two-story buildings). These buildings contained eighty one-bedroom apartments, 240 twobedroom apartments, and eighty three-bedroom apartments. ${ }^{201}$ Work was underway by mid-J uly 1950, with the large construction crew quartered at Camp Forsyth. ${ }^{202}$

By December, eighty units were nearing completion, and several were opened to occupancy by mid-J anuary 1951. The project also included provision of utilities, sidewalks, streets, landscaping, playground equipment, and a few basement recreation rooms. The entire project was finished in J une 1951, and was named Colyer Heights a few years later, in honor of Sgt. Wilber E. Colyer, a fallen World War I 1st ID Medal of Honor winner. 203

Housing was not the only need to be met by converted buildings. Construction bids were received in J une 1947 to convert the former Station Hospital Building into a headquarters building. ${ }^{204}$ The low bid for the headquarters conversion was again received from contractor Mont. J . Green. The revamped facility provided a central operation office, along with a coffee shop and soda fountain. The new headquarters opened for

\footnotetext{
200 “Fort Housing Assured," Junction City Union, 24 June 1950, 1.

201 Ibid.

202 “Progress On Housing," Junction City Union, 29 July 1950, 1.

203 “New Housing Units Nearing Completion," Junction City Union, 5 December 1950, 1; “Open Post Housing," Junction City Union, 12 January 1951, 1.

204 “Plan a New Headquarters," Junction City Union, 12 June 1947, 1.
} 
business on 11J une 1948 after completion of the $\$ 195,000$ conversion work. 205

A series of recreation needs were met, beginning on the Main Post with conversion of the East Riding Hall to a field house. Initial work consisting of replacing wooden roof trusses with steel ones and installing a new slate roof. The roofing contract went to the O.D. Milligan Construction Company of Manhattan. 206 The conversion costs were estimated at \$200,000 and bids were received. ${ }^{207}$ The O.D. Milligan Construction Company also won the contract for the facility conversion. The new field house included bowling alleys, a squash court, dressing and massage rooms, and a basketball court which could also be used for boxing. ${ }^{208}$ The conversion was completed in late November 1948. ${ }^{209}$

Other new recreational developments included a new golf driving range and two new all-weather skeet ranges. Those facilities opened 30 August and 15 September 1947, respectively, and were located just west of the Fort Riley Polo Bungalow at Camp Forsyth. ${ }^{210}$ Then in August 1948, the War Department Theater No. 1 was repaired with a neon sign for the marquee, illuminated display signs, rubber matting for the lobby, cement wainscoting in the lobby and foyer, a refinished stage floor, and improved restrooms. ${ }^{211}$ Also included were new slip covers for the chairs, a new flameproof main draw curtain, and valance and stage mechanisms. ${ }^{212}$ An indoor golf driving range opened December 1948 in Building 660, on Sixth Street in Camp Whitside. ${ }^{213}$ In addition, by September 1948, Fort Riley residents could choose from five seasonal swimming pools. ${ }^{214}$

\footnotetext{
205 “Plan Further Post Changes," Junction City Union, 23 January 1948, 5; "Post Headquarters Moving Into New Building Today," Junction City Union, 11 June 1948, 1.

206 “Bids for Post Gym Sept. 23," Junction City Union, 15 September 1947, 1.

207 "Field House is Approved," Junction City Union, 22 July 1947, 1.

208 "Submit New Bids For Post Gymnasium," Junction City Union, 11 November 1947, 1.

209 “New Field House Almost Completed," Junction City Union, 23 November 1948, 1.

210 "New Skeet Range Ready at Forsyth," Junction City Union, 15 September 1947, 1; "Golf Driving

Range Open at Fort Riley," Junction City Union, 30 August 1947, 1.

211 “Fort Riley News," Junction City Union, 14 September 1948, 3.

212 Ibid.

213 "New Facilities Opened at Fort: Indoor Gold Driving Range Ready for Use; New Bowling Alleys in Use

Saturday," Junction City Union, 21 December 1948, 1.

214 “Fort Riley News," Junction City Union, 14 September 1948, 7.
} 
A field house at Camp Funston was begun in 1949 by erecting a surplus prefabricated hangar, but was not finished due to lack of funds. A $\$ 62,000$ contract to finish construction was let to the Mont. J . Green Construction Company in May 1950. Most of the funds came from non-appropriated welfare money earned from post exchanges, theaters, and other similar operations. The facility opened on December 1, 1950, with an exhibition basketball game. The field house offered a full-size basketball court with grandstand, two locker rooms, exercise equipment room, an office, ticket lobby, and eight bowling alleys. Activities offered included boxing, fencing, wrestling, badminton, tumbling, and general exercise. ${ }^{215}$ Shortly after opening, the building was damaged by an explosion from the furnace system on J anuary 11,1951 . The damage was estimated at $\$ 15,000-\$ 20,000$ to the building, and was quickly repaired. 216

In 1951, a major flood caused devastation to parts of Fort Riley and resulted in large clean-up, repair, and reconstruction efforts. By midOctober, seventeen contracting firms had begun $\$ 5$ million worth of work encompassing thirty-seven different projects at various locations. At Camp Funston and Camp Forsyth, repair and reconstruction of buildings was the main priority. General rehabilitation of the field and replacement of runway lights was progressing at Marshall Field, and buildings were repaired at Camp Whitside. Several more comprehensive projects were also being carried out, including reconstruction of the Post electrical system, drilling new wells, resurfacing roads and parking areas, and sewer repairs. ${ }^{217}$

To do their part in flood clean-up, the Post's engineer troops immediately began working to restore roads, levees, and utility systems. This work was accomplished quickly, providing the least-possible disruption to normal training. One of the largest projects was to remove the silt residue and start repairing the levees, as well as clearing roads, leveling ground, and landscaping. 218 Work in the Camp Funston area focused first on utilities, then shifted to the approximately eighty buildings that had been moved off their foundations. The buildings were returned and floors, wall coverings, and other damaged material removed. Cleaning and new paint brought

\footnotetext{
215 "To Finish Camp Funston Field House," Junction City Union, 9 May 1950, 1; “Camp Funston Field House to Be Opened Friday Evening," Junction City Union, 30 November 1950, 15.

216 “Explosion Damages Gym At Funston,” The Fort Riley Post, 13 January 1951, 1.

217 “Construction, Repair Involves Firms to Total Nearly \$5 Million," Junction City Union, 18 October 1951, 17.

218 “Post Flood Rehabilitation Open to Visitors' Inspection,” (Fort Riley) Guidon, 14 May 1952, 8.
} 
most of the buildings back, but some were beyond repair and were demolished. The evacuated troops were able to return to their barracks by late fall. By the time rehabilitation work at Camp Funston was finished in March 1952, there were twenty-seven new buildings, including twelve barracks, new classrooms, modernized service clubs, and a refurbished headquarters building and field house. ${ }^{219}$

Engineer Bridge over the Kansas River between Marshall Field and the Main Post had been heavily damaged, and one of the first engineer efforts was the construction of what was the largest pontoon bridge in the United States. This enabled emergency repairs to streets, runways and parking areas at Marshall Field to begin, along with the basic clean-up work. Repairs to Engineer Bridge consisted of replacing two spans, and was completed by the end of 1951. ${ }^{220}$

Engineer troops sent from Camp Carson and Camp McCoy had done the majority of the work, particularly with the Engineer Bridge and the repair of levees. This included a new \$2-million 3.5-mile dike constructed around three sides of Camp Funston to prevent a reoccurrence of the high water. 221

As mentioned in the 1945 Utilization study, Fort Riley needed to upgrade its utilities. Work was accomplished toward this end in the early 1950s, with a new water treatment building at Camp Forsyth and a post-wide improvement of the telephone system. That rehabilitation of the telephone exchange system resulted in a dial system for Camp Forsyth, service to the new Wherry apartments, improved service on the Main Post, and improvements in the connection to J unction City. ${ }^{222}$ New equipment was added at the Main Post exchange, and a new building was constructed at Camp Forsyth in 1952 to house the dial exchange in that area (Figure 19). 223

\footnotetext{
219 Ibid; “What a Difference 8 Months Made,” Guidon, 12 March 1952, 8.

220 “Post Flood Rehabilitation Open to Visitors' Inspection," 8.

221 "New Dike May Save Another Extended Bivouac for Division," Guidon, 12 March 1952, 8.

222 "The Fort Telephone System is Presently Undergoing Change," Guidon, 8 October 1952, 1. 223 Ibid.
} 


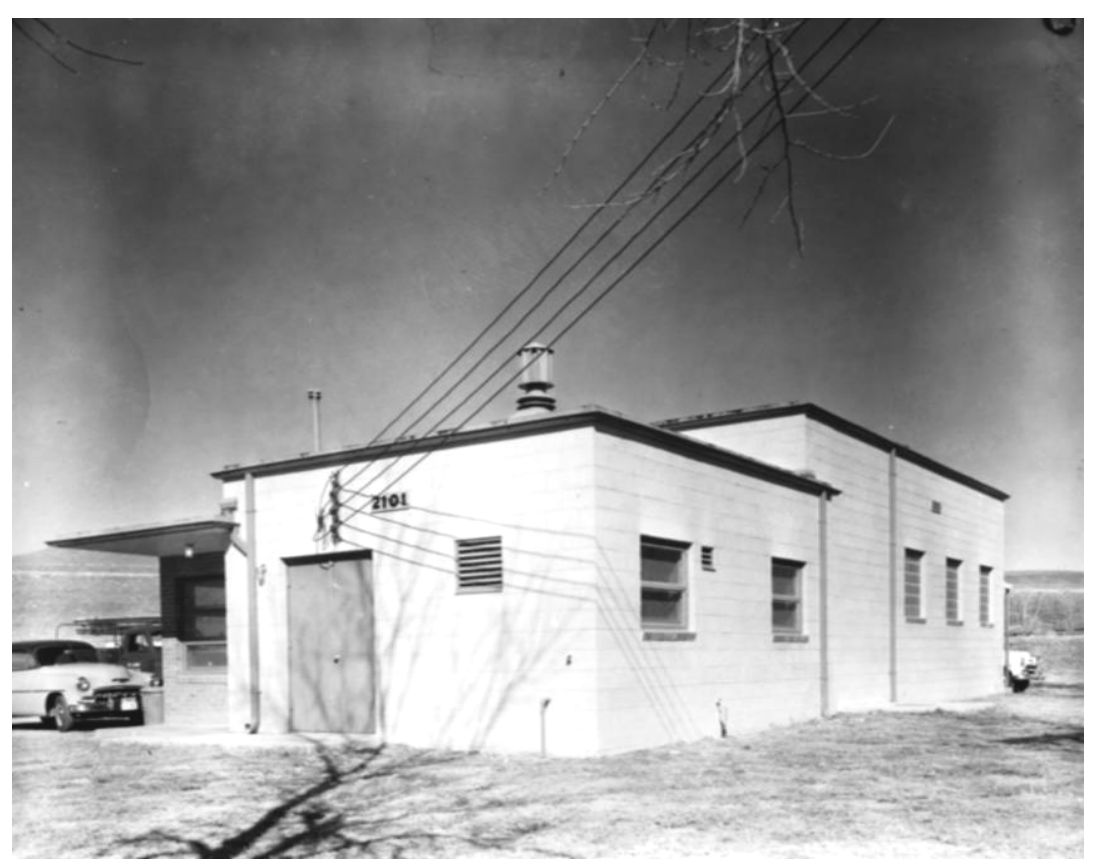

Figure 19. Building 2101, new telephone exchange building, Camp Forsyth, 1954 (NARA).

\subsection{Fort Riley between Korea and Vietnam}

As the Korean War Armistice Agreement was finalized and signed in 1953, Fort Riley still resembled the installation resulting from World War II. Rows of temporary barracks and other buildings covered Camps Forsyth, Funston, and Whitside, the Main Post retained its nineteenth-century limestone sentinels, and Marshall Field supported fixed-wing transport. As a result of the emergent cold war, a standing peacetime Army became reality for the United States. The need to respond quickly to threats to democracy from any part of the globe required new methods of military preparedness. Various approaches for stationing, housing, training, and transporting these troops were created, tried, and usually discarded during the 1950s.

Fort Riley's mission emphasis on training continued throughout the 1950s, but various changes occurred in content, and a nearly wholesale turnover of units in the mid-1950s resulted in new training activities and new infrastructure. By 1960, an entirely new housing and support area would begin to spread over the crown of Custer Hill to support a change in mission that drew a large, new population of soldiers. Also during that time, medical 
facilities on post would take a giant stride forward, and a new type of military aircraft would necessitate new construction at the airfield. ${ }^{224}$

J ust weeks before the Korean War cease-fire, Fort Riley celebrated its centennial with a lavish three-day open house for the public on 26, 27, and 28 June 1953. As a result, local coverage provided a snapshot of the post in June 1953. The 100-year-old installation was home to an estimated 16,000 troops, mostly at Camp Funston; from 1,000 to 1,500 civilian employees, and perhaps 1,600 to 2,000 dependents living on post. Fort Riley covered 51,168 acres, and contained over 3,000 buildings for offices, shops, classrooms, barracks and quarters. ${ }^{225}$ The post also had artillery and small arms ranges, and maneuver areas, all "located at convenient distance from the garrison areas, requiring the minimum time loss in moving troops." 226 The most glaring construction need was for a new hospital. Such a building had been planned for years, and had received approval, but no funds had been appropriated to meet the estimated \$7 million cost. ${ }^{227}$ As expressed in a J unction City Union article about the centennial, "what the future holds for Fort Riley is basically dependent on a lot of factors, such as national policy, congressional appropriations, world peace and Russia's behavior, but top military authorities hold Fort Riley and its fine facilities in high regard." 228 What the future ended up holding was a continued emphasis on combat training, continued development of Army schools, and a massive relocation of troops to Fort Riley.

\subsubsection{Combat training and Army schools}

\subsubsection{Basic infantry training}

After the 27J uly 1953 cease-fire, the mission of troop training continued at Fort Riley. The $10^{\text {th }}$ ID had begun providing combat replacement training at Fort Riley in 1948. The main unit on post, the 10 th ID was one of nine such training divisions in the United States Army. The training was for combat infantry replacements, to keep established units up to strength; most replacements went to Europe or the Far East. The trainers and train-

\footnotetext{
224 For a history of the installation prior to 1953, see Pamela Andros, et al., Historical and Architectural Documentation Reports for Fort Riley, Kansas, (Champaign, IL: Construction Engineering Research Laboratory, 1993).

225 “One of Nation's Top Military Posts," Junction City Union Centennial Edition, 24 June 1953, 1.

226 Ibid.

227 Ibid.

228 Ibid.
} 
ees utilized Camp Funston and in 1953, numbered about 10,000. Training for these soldiers consisted of two similar programs developed by Army Field Forces; one focused on light weapons, and the other on heavy weapons. Most of the training was conducted by three training regiments; each assigned certain subjects of study. The $85^{\text {th }}$ Regiment has supervision of tactical and intelligence subjects; the $86^{\text {th }}$ Regiment heavy weapons and some general subjects; and the 87th Regiment light weapons and other general subjects. ${ }^{229}$

For the trainee, his bunk at Camp Funston marked the last of a series of rapid location shifts. After being inducted in his local community, he would be sworn in at that area's induction station. Next stop was a reception center where in about five days, basic equipment was issued, tests were taken, classifications made, and a training station assigned. Moving on to his training station, the earlier classification and test results were used to decide if the recruit was assigned either to a sixteen-week combat replacement cycle or to an eight-week branch immaterial cycle ${ }^{230}$

For the combat infantry replacement basic training, and indeed for all basic training, the primary lesson was use and care of the M-1 rifle with bayonet, the soldier's personal arm (Figure 20). Instruction was also provided on other weapons such as grenades, bazookas, machine guns, mortars, and recoilless rifles. Other subjects of study included attack and defense tactics, protective measures against chemical, biological, and radiological attack, field sanitation, personal hygiene, and first aid. Instruction was also given in hasty fortifications and camouflage, squad and platoon tactics, and patrolling. The training cycle also included a two-week bivouac in the field, which included testing and further training involving solving combat field problems while under fire, urban and close types of combat, and mastery of the battle indoctrination course. ${ }^{231}$

Training methods for the soldier's primary arm were altered in 1959- 1960 with the introduction Army-wide of TRAINFIRE I as the new Basic Rifle Marksmanship Course. TRAINFIRE consisted of a new method for training designed to more accurately simulate combat shooting. Man-sized

\footnotetext{
229 “Training of Combat Infantry Mission of the Tenth Division," Junction City Union, 24 June 1953, 1.

230 "Branch immaterial" refers to subjects of general military nature, without specific application to any branch of the service.

231 "Training of Combat Infantry Mission of the Tenth Division," 1; "Bivouac Training A Realistic Review of Soldier's Lessons," Junction City Union, n.p.
} 


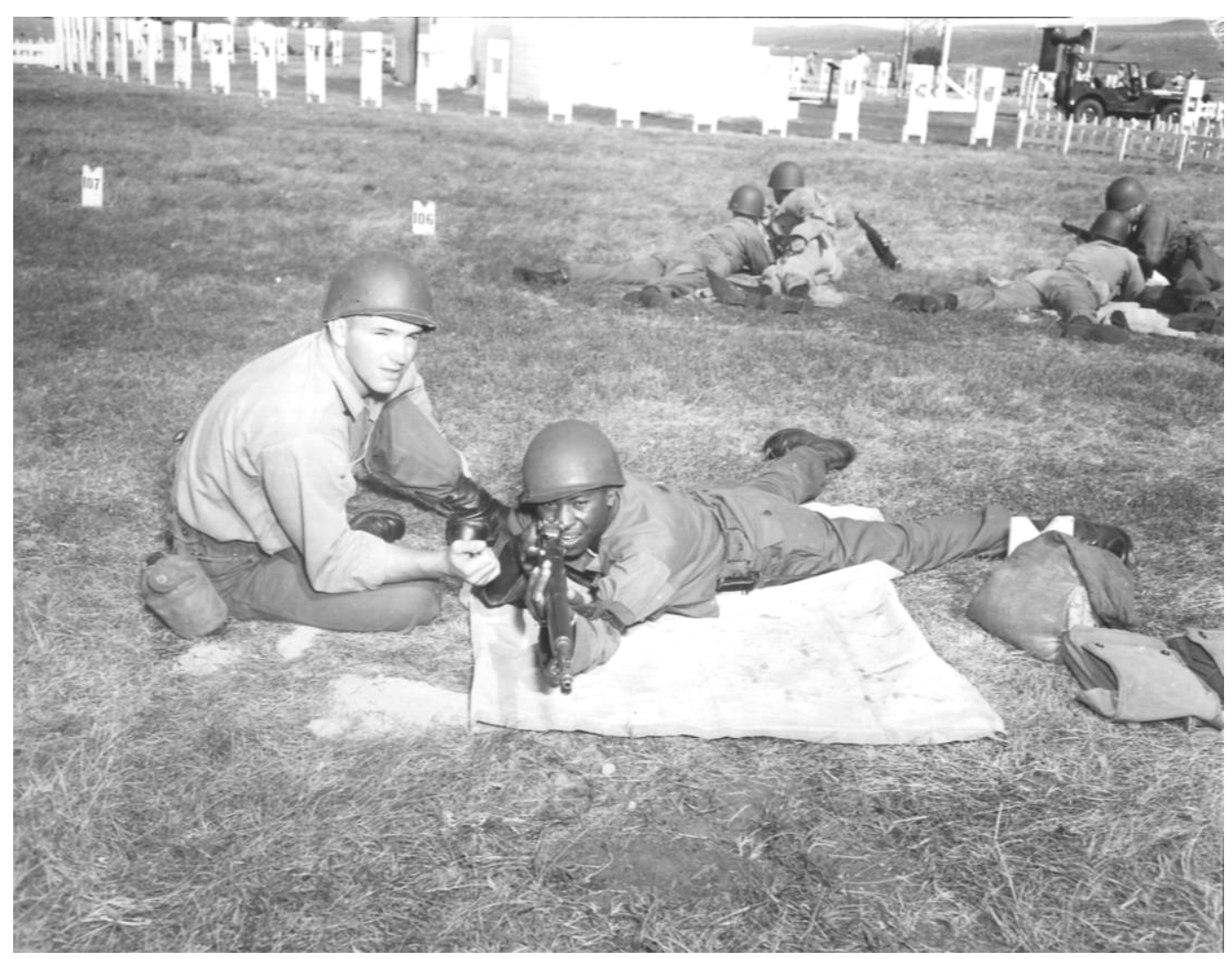

Figure 20. Rifle Range Training at Fort Riley, 1953 (NARA).

pop-up targets were utilized instead of the traditional bulls-eyes. The range facilities provided targets at various distances that would appear for limited amounts of time during for the soldier to acquire, aim, and shoot (Figure 21). Fort Riley was allocated $\$ 200,000$ for constructing three TRAINFIRE ranges in 1959. In addition to the target emplacement, prefabricated buildings were acquired for placement at the ranges and used for support functions such as target storage and latrines (Buildings 7710, 9081, 9165, 9166, 9185, and 9186). ${ }^{232}$

The practical training was supplemented with more academic subjects geared to military life including Army traditions, military customs and courtesy and military justice.233 The 10th ID also provided training in leadership for NCOs, specialist training to clerk-typists, unit supply specialists, wheeled vehicle mechanics, field wiremen, radio operators, and

\footnotetext{
232 Headquarters, United States Continental Army Command, Fort Monroe, VA, Letter to Deputy Chief of Staff for Logistics, Department of the Army, Washington, DC, 12 June 1957, Record Group 337, Entry \#3 (UD-WW), Box 37, Folder: 600 Binder \#3, National Archives and Records Administration, College Park, MD.

233 “Training of Combat Infantry Mission of the Tenth Division," Junction City Union, 24 June 1953, 1.
} 


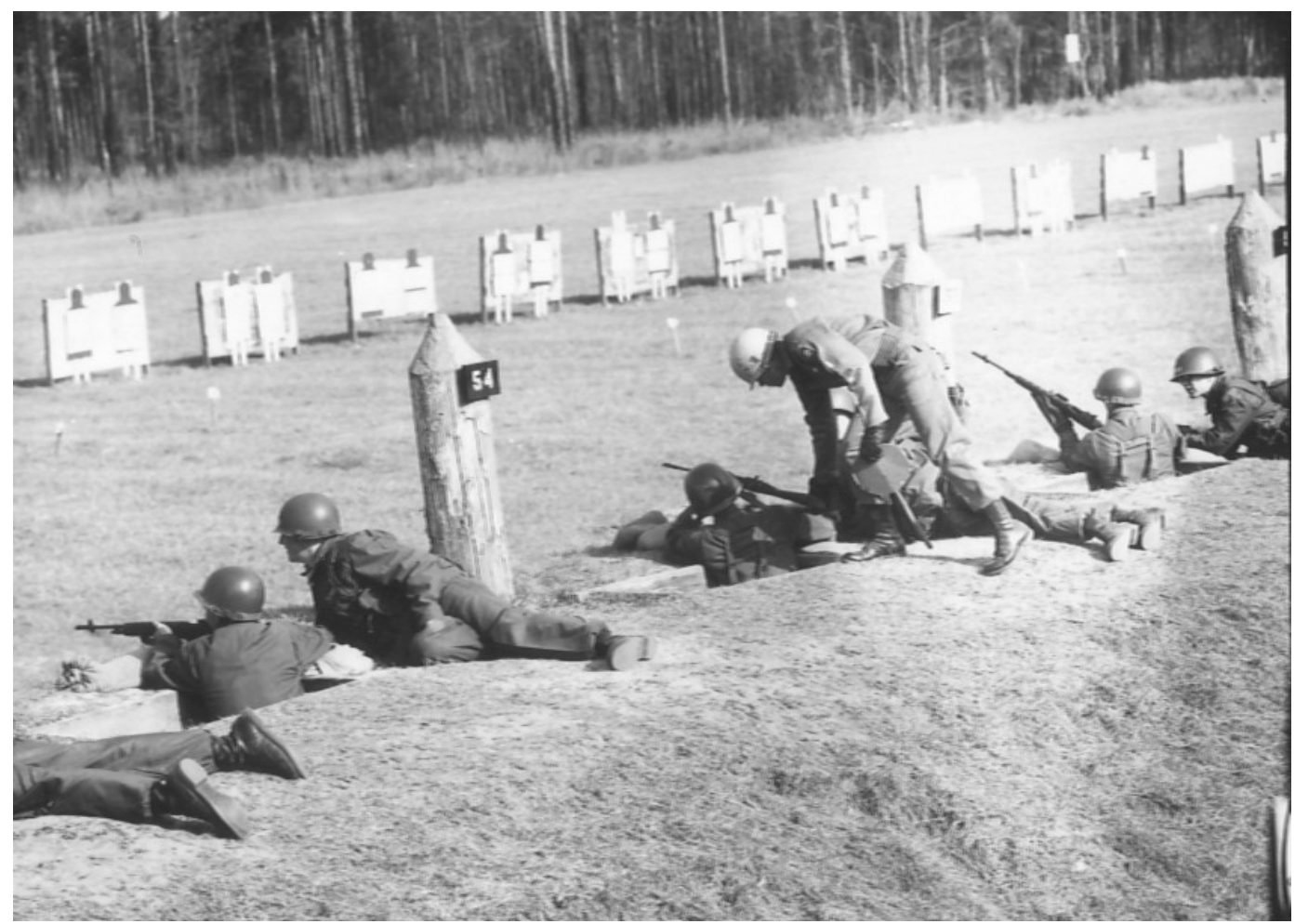

Figure 21. Training on the zero distance TRAINFIRE Range at Fort Stewart, Georgia, 1966 (NARA).

vehicle drivers, and branch immaterial training to soldiers who then followed on with specialist training for other branch replacements. ${ }^{234}$

\subsubsection{Military education training}

In addition to basic and specialist training, Fort Riley was home to the Army General School. Founded on 1 November 1946 as the Ground General School, it succeeded the famed Cavalry School at Fort Riley, providing the post with an unbroken string of service schools stretching back to the late $19^{\text {th }}$ century. The mission of the Ground General School was to provide training to officers and men as S2 and G2 personnel, up to division level and to train certain types of intelligence specialists. 235 The school also provided facilities for instruction in the branch immaterial studies for officers and enlisted men. Re-designated the Army General School in 1950, these instruction tasks continued as before. Additional missions given the school included development of tactics and techniques for the Aggressor Cadre, and serving as the unit's home. Several distinct educational entities were part of the Army General School: the Department of Resident Instruction,

234 “One of Nation's Top Military Posts," Junction City Union, Centennial Edition, 24 June 1953, 1. 235 “Army General School Nears Its 64th Year at Fort Riley," Junction City Union, 24 February 1955, 4. 
The Intelligence Division, and the Department of Non-Resident Instruction. 236

The Department of Resident Instruction supervised all of the Army General School training conducted on post. The Department of Non-Resident Instruction prepared and distributed instructional materials as correspondence courses to over 30,000 Army and civilian personnel every month. More than 130 different courses were offered by mail, with the Department staff grading work and sending out marks. Renamed the Extension Courses Division by 1955, the logistics involved resulted in the Division housing a printing plant, bindery, drafting and art sections, storage areas, and a photo laboratory. 237

The Intelligence Division provided instruction for officers and noncommissioned officers in "general intelligence, aerial photo interpretation, order of battle, interrogation of prisoners of war, technical intelligence coordination, censorship, and strategic intelligence research and analysis." ${ }^{238}$ As the only school of its type, instruction was not limited to Army personnel, but included students from the Navy, Marine Corps, and Air Force.

The Army General School was discontinued in July 1955, as the mission of Fort Riley changed with the arrival of the 1st ID. The departments were scattered to other installations, with only the Aggressor Cadre remaining at Fort Riley as a separate organization. The Non-Commissioned Officer's Academy at Fort Riley replaced the General School. 239

By March 1951, a Chemical Biological Radiological Warfare course was running at Fort Riley. The nineteen hours of training included information on the types of chemicals used by the Army, their capabilities, how to detect them, and how to protect one self from them. By March 1953, the 5th Army Chemical Biological and Radiological Warfare School had moved from Camp McCoy, Wisconsin, to Fort Riley. The three-week course included lectures, laboratory work, and field exercises. The exercises included "sounding out" sources of radioactivity with Geiger counters and a

\footnotetext{
236 "Army General School Is The Successor to Cavalry School," Junction City Union, 24 June 1953, 1. 237 Ibid. 
gas confidence course. 240 To support this new school, a new ordnance component was created, the 5th Army Chemical Field Maintenance Repair Shop. The new shop opened in February 1953 and was charged with "decontamination and impregnation of equipment used for training." 241 The entire school operated in the Camp Forsyth area. On 25J une 1954, the school ceased operation on order of Lieutenant General William Kean, Commanding General of the 5th Army.

New construction at Fort Riley during the years 1953 and 1954 was virtually non-existent, and public works efforts concentrated on keeping the older facilities up and running. By the summer of 1954, changes were underway that would shift the mission at Fort Riley and result in a large number of new, permanent buildings. For the time period under study, the historically significant themes and patterns for Fort Riley occurred between 1955 and 1960. These themes involved a new method of troop stationing and rotation, a leap ahead in providing medical services, and an expanded role for Army Aviation.

\subsubsection{Operation Gyroscope}

Personnel changes at Fort Riley began in February 1954, with the announcement that the 37th ID would relocate from Fort Polk, Louisiana, to Fort Riley. This move was part of an Army-wide redeployment plan to adjust to a 300,000 troop reduction in strength brought on by the end of the Korean War and large numbers of troops returning to the United States. 242 By May, plans were for the $37^{\text {th }}$ to be reorganized as the $10^{\text {th }}$ ID, which itself would be reorganized from a training division to a Regular Army combat division on 15J une 1954. The troops began arriving 3 May by plane, train, and motor convoy. ${ }^{243}$

\subsubsection{The Gyroscope concept}

As a combat division, the 10th ID was eligible for overseas duty, and just at that time, plans were being drawn up at a very senior Army level for a new

\footnotetext{
240 "Students at Post Taking Course in Chemical Warfare," Junction City Union, 26 March 1951, 7; “New Army School to Open Monday," Junction City Union, 5 March 1953, 1; “Fifth Army School At Fort Riley Is Two Years Old," Junction City Union, 30 July 1953, 1.

241 “New Shop At Fort Riley,” Junction City Union, 4 February 1953, 1.

242 “37th Infantry Division Likely to Get New Name," Junction City Union, 16 February 1954, n.p.

243 "Members of 37th Due to Arrive Tonight," Junction City Union, 4 March 1954, 1; "Expect 1,800 From the 37th," Junction City Union, 1; “37th Division To Be The 10th," Junction City Union, 8 May 1954, 1.
} 
and revolutionary method of troop rotation and replacement. As an alternative to the individual soldier replacement that was customary, the new plan went as far the other direction as possible, instituting simultaneous movement of entire battalions, regiments, or even divisions. Christened Operation Gyroscope, the plan was strongly supported by Army headquarters for several reasons, most importantly increased stability and combat effectiveness, higher morale, and reduced costs.

Stability and combat effectiveness were expected to increase due to the gyroscope units having a permanent home base in the United States, which they would return to after each three-year rotation overseas. This would provide better planning for installation facility needs, and training could be directly tailored to the unit's needs. Additionally, Operation Gyroscope also represented an attempt to place a new soldier in a unit that would remain "home" for most of their military career. Combat effectiveness would be increased through increased retention of trained personnel, more integrated teamwork, and experience in moving large groups of personnel. ${ }^{244}$

Several aspects of the new system hoped to raise morale for the soldiers. Most importantly, family life was expected to be more stable, as a permanent home base would allow more continuity for raising children and purchasing a home. Key to the system was allowing dependents to travel to the new station at the same time as the soldier, eliminating long periods of separation. By rotating location, not personnel, it was anticipated that esprit de corps and a more predictable work environment would translate to better morale and higher retention levels of trained personnel. ${ }^{245}$

Cost savings were to be achieved by volume shipment and processing of troops. Since the movements were bi-directional, the trains, motor vehicles, and vessels utilized to move one unit were immediately available to return full with the other troop unit. Shipping costs were also reduced as the troops left their organizational equipment behind for use by the arriving unit. Increased reenlistment levels would also produce cost savings through lower training costs. ${ }^{246}$

\footnotetext{
244 David A. Lane, Robert Gumerove, and Elizabeth W. Hotlzworth, Operation Gyroscope in the United States Army, Europe, (Headquarters, United States Army, Europe, Historical Division, 1957), 1:2-3.

245 Ibid, 1:1-2.

246 Ibid, 1:3-4.
} 
In reality, complete simultaneous movements of divisions was not practical, primarily as combat readiness overseas could not be threatened by the rotation process with an entirely new unit taking up stations. This difficulty was solved by moving divisions in increments with each regimental combat team moving separately at two-month intervals and division headquarters moving with the middle increment. Each group would have been training for their new mission for six months before arrival, so operational effectiveness would not be affected. While in the United States, the Gyroscope unit would have a mission related to maintaining combat readiness, usually including the training of selectees beginning six months prior to the next overseas rotation. ${ }^{247}$

The Gyroscope concept was debated in the summer of 1954, and a formal announcement of the program came in a press release that September, with formal approval the next month. Operation Gyroscope, the largest peacetime movement of troops in U.S. history, was scheduled to begin 1 J uly 1955. Although the initial participants had been selected by October 1954, they weren't announced publicly until March 1955. Seven installations were involved in the new system: Fort Riley, Fort Lewis, Fort Ord, Fort Hood, Fort Campbell, Fort Benning, and Fort Bragg. The first rotation involved four units - two Infantry Divisions and two Armored Cavalry Regiments. ${ }^{248}$ Fort Riley played an important role right from the start, as the $10^{\text {th }}$ ID was selected to rotate to Germany replacing the 1 st ID, which would take up permanent station at the fort. This would mark the first time that Fort Riley would be a full division post during peacetime.

\subsubsection{Implementation at Fort Riley}

The 10th ID had been preparing for the July move since at least the first of the year. Extensive lists of people and property had been developed by mid-March. In addition to dependents and personal property, the Division needed to move "315 dogs, nine cats, and two monkeys as pets." 249 To accomplish the move, an estimated 15,420 packing crates would be required. As the units were not transporting organizational equipment, this number represented a steep reduction from previous requirements. For the $1^{\text {st }}$ ID, a unit that had been stationed in Germany since the end of WWII, an esti-

\footnotetext{
247 Ibid, 1:4-5.

248 Ibid, 2:2.

249 “Operation Gyroscope Gains Momentum As First Division Prepares for Shift," Junction City Union, 21 March 1955, 1.
} 
mated 7,700 tons of baggage would need to be delivered to Fort Riley. 250 In essence, the operation was equivalent to moving two communities of 22,000 people. At the end of the journey, the arriving families would walk into the quarters and find everything ready for use, including a fully stocked kitchen and pantry. ${ }^{251}$

After months of training and planning, the first increment of $10^{\text {th }}$ ID troops left Fort Riley on $29 \mathrm{~J}$ une 1955. The first 500 of a group numbering 6,000 boarded trains bound for the port of embarkation at New York City. From there, four ships would carry them and their families to Bremerhaven, Germany in less than two weeks. By 17J uly, the first full increment had moved. The second and third increments followed in September and November. 252

On the other side of the Atlantic, plans also proceeded apace for the 1st ID's return to the United States after thirteen years overseas. The same pattern of three increments two months apart produced a schedule that allowed the $1^{\text {st }}$ ID to utilize ships just vacated by $10^{\text {th }}$ ID troops. Due to the fame of the 1 st ID, and their long absence from American shores, they received a rapturous reception in New York. The first troop ship bearing troops of the first increment arrived on 23 J uly 1955. They were met by fire boats, police craft, Coast Guard helicopters, and a Navy blimp. A two-hour ceremony included the 328 ${ }^{\text {th }}$ Army Bank, a color guard review, and speeches from high-ranking military personnel and the New York City Mayor Robert F. Wagner, J r. ${ }^{253}$ Their welcome to Fort Riley was a bit smaller in scale, but just as enthusiastic when the first trainload arrived two days later. The high point of the day for many was likely the fact that the normal prescribed meal order for the day, C-rations, was cancelled in favor of a steak dinner for all 1st ID personnel. 254 As the 1st ID troops continued to arrive over the next five months, they were quartered in temporary World War II construction at Camp Funston.

\footnotetext{
250 “Division Needs 15,420 Crates for Overseas Move," Junction City Union, 9 April 1955; “Army Preparation for First Division's Shift to Fort Riley Are Well Underway," Junction City Union, 25 April 1955, 1.

251 “Army Preparation for First Division's Shift to Fort Riley Are Well Underway," Junction City Union, 25 April 1955, 1, 7.

252 “10th Division Troops Start On Gyro Trip," Junction City Union, 29 June 1955, 1.

253 “1st Division Welcome Set At New York," Junction City Union, 19 July 1955, 1.

254 “First Division Group Due at Post Monday,” Junction City Union, 21 July 1955, 1.
} 
The initial rotation of Operation Gyroscope troops was judged a great success, and several more rotations occurred over the next few years. Problems with the system did, however, become apparent over time. Retention of experienced personnel varied with the availability of family quarters overseas. Combat readiness suffered upon arrival overseas due to lack of sufficient training time before rotation and again before departure back to the United States due to early departure of key personnel to the home station. These difficulties were lessened when battalion or regimental size units were rotated. ${ }^{255} \mathrm{~A}$ scaled-down program was implemented to move only some division units, but the personnel issues and their effect on readiness continued, and resulted in a decision to end the program on 1 September 1959. Fort Riley remained the home station of the $1^{\text {st }}$ ID.

While at Fort Riley, the 1st ID began its home mission of providing basic training for new recruits, fresh from reception centers. Summer training of U.S. Army Reserve and National Guard units was added to the mission, with trainees stationed at Fort Riley, and some 1st ID troops supporting training at Camp McCoy, Wisconsin.

The 1st ID had another "first" when, in February 1957, it became the first conventional U.S. Infantry Division to be completely reorganized into a "Pentomic" unit. The Pentomic organizational concept was created to produce an Army that was capable of fighting both a conventional and a nuclear war. For the Infantry, units were reduced in size to make them more maneuverable, and new transportation support elements were added to increase speed of movement. Heavier firepower was provided by adding Honest J ohn rocket launchers and the eight-inch howitzer, both capable of firing atomic artillery shells. Aviation support was also given an increased role as part of the effort to increase mobility, particularly by greater utilization of helicopters and low-speed fixed-wing aircraft. Fully implemented in the Regular Army by 1958, the Pentomic Division concept began to lose luster by 1960 due to difficulties in controlling diverse units mashed together, loss of maneuver training time for officers, and loss of unit cohesion with the departure from traditional infantry regiments. ${ }^{256}$

\footnotetext{
255 Lane, Gumerove and Hotlzworth, Operation Gyroscope in the United States Army, Europe, 5:2-5. 256 Office of the Chief of Military History, American Military History, Chapter 26: The Army and the New Look, rev .ed., (Washington, D.C.: United States Army, 1988), 13-14; 1st Infantry Division and Fort Riley Information Office, First Infantry Division Yearbook: 41st Anniversary, 1917-1958, (Fort Riley, Kansas: U.S. Army, 1958), 67, 76.
} 


\subsubsection{Construction for Operation Gyroscope}

The stationing of such a large number of soldiers and their dependents at Fort Riley necessitated a construction program that involved a large number of new troop housing facilities. Over time, the site grew to include recreational, retail, administrative, training, religious, fitness facilities, and other support facilities. The area known as Custer Hill was selected for this expansion due to the large amount of land on which to build, and the fact that it provided higher ground. This was surely on the planners' minds after the recent 1951 flood, which highlighted the need to remove troops from Camp Funston and Camp Forsyth. Construction began in 1955 on the first new barracks. Although the post had originally requested twelve barracks, only six were funded. This was part of a 50percent Senate reduction in military public works construction for housing at all military posts requesting more than one barracks passed in J uly 1954.257 The funding amount included roads and utilities for the new barracks, and site surveys were already under way before the funding was assured. By the time the funds were appropriated, a construction site had been selected in the Custer Hill area.

Bids for the six barracks were received on 25 October 1954. The estimated cost of $\$ 3$ million was just a beginning to developing the Custer Hill area as part of an effort to provide permanent buildings for troop housing at Fort Riley. ${ }^{258}$ The three-story barracks were of a standard Army design known as Hammerheads, with the wider, one-story "head" being the mess hall. Hammerhead barracks were built on Army installations across the country during the early and mid-1950s. Designed to house a company of soldiers in a self-contained manner, the barracks plans included sleeping, eating, administrative, storage, and recreational spaces for 235 men within one building. Constructed of reinforced concrete with concrete block walls, the barracks buildings had built-up roofing and individual heating plants (Figure 22). 259

\footnotetext{
257 “Ask \$7,413,000 for Fort Riley Housing," Junction City Union, 7 April 1954, 1; "Building Funds For Fort Riley Reduced in Senate," Junction City Union, 7 July 1954, 1.

258 "Bid on New Fort Housing October 25," Junction City Union, 4 October 1954, 1; These Hammerhead barracks were demolished in 2000 for new development at Custer Hill.

259 Ibid.
} 


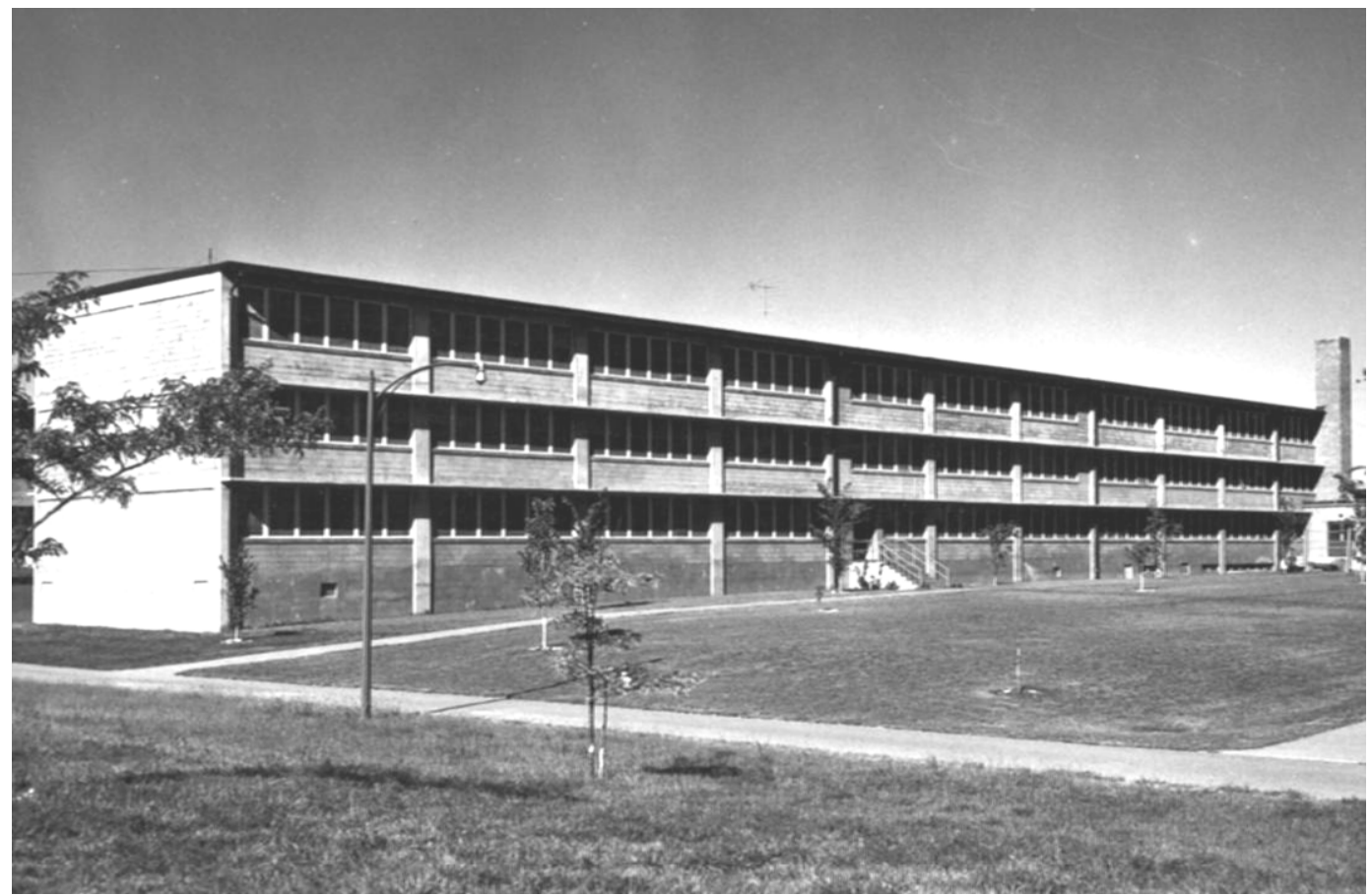

Figure 22. Completed Hammerhead barracks, mid-1950s (Museum Division, Fort Riley).

With the bids coming in at 3.5 million dollars, contractors soon got to work, led by the main project contractor, Dodlinger Construction Company (Figure 23). The contracts called for completion of the Custer Hill Troop Housing Project, as it was called, by spring 1956. The barracks were constructed in a production line method, so when one step was completed on the first building, it was repeated on the next and so on, while on the original building work proceeded to the next task. Utilities were installed at the same time, with electrical wires being strung and water, sewer, and gas pipes placed underground. ${ }^{260}$

During the spring of 1955, two additional Custer Hill projects were underway and also were expected to be completed by the following spring. Bids for the construction of a sewage treatment plant were accepted on 12 April. A Bachelor Officer's Quarters (BOQ) construction project had bids received on 25 April. The low bid of $\$ 297,094$ for the BOQ was submitted by the Green Construction Company of Manhattan, Kansas. The three-story building had a concrete frame and concrete block walls, similar to the six 
new barracks. Construction was expected to take 280 days. Both facilities were to provide support for the new barracks. ${ }^{261}$

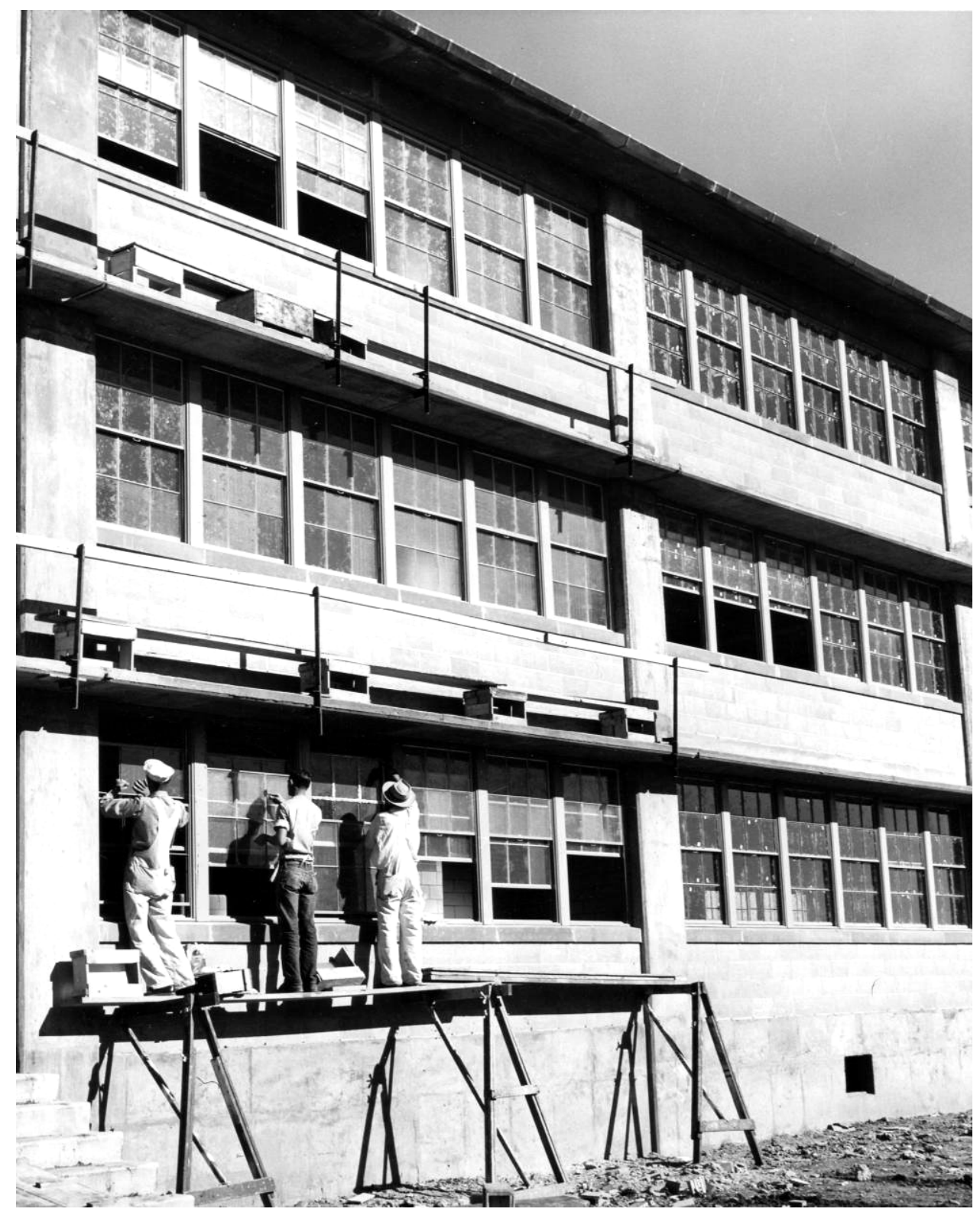

Figure 23. Barracks construction at Custer Hill, 1955 (Museum Division, Fort Riley).

By mid-1955, Fort Riley was well into the beginning phase of a huge construction project at Custer Hill that would eventually provide housing and other facilities for a full division. At that time, an estimated cost of $\$ 70$ 
million was given for construction of the entire development. ${ }^{262}$ At the beginning of FY 1956, Fort Riley was poised to receive another $\$ 8,657,000$ for military construction. ${ }^{263}$

The FY 1956 building program request for Fort Riley was both broader and larger than the previous year, as the Custer Hill development efforts

picked up steam with the arrival at the fort of the 1st ID. The lion's share of the $\$ 8,657,000$ request included a variety of facilities for Custer Hill: 264

- Family quarters for dependents of military personnel - \$2,250,000

- Four battalion headquarters buildings - $\$ 168,000$

- Four classroom buildings - $\$ 211,000$

- Four motor repair shops - $\$ 286,000$

- Hardstand for motor pool - \$155,000

- Motor park facilities - $\$ 75,000$

- Regimental dispensary - \$119,000

- Branch PX - \$72,000

- Enlisted men's service club - \$462,000

- Theater - $\$ 331,000$

Two years into the construction, the first group of six barracks with mess, roads, and utilities were almost finished. ${ }^{265}$ Except for the theater, work had begun on the buildings listed above (Figure 24 and Figure 25). The Post Exchange opened in 1958 and provided a cafeteria, watch repair and photo studio, laundry and dry cleaners, with a record department added shortly afterwards. ${ }^{266}$ The Custer Hill area continued to expand the following year, with the FY 1957 construction program request including a regimental headquarters, a regimental gymnasium, a regimental chapel, and the already approved theater. ${ }^{267}$ It took several years for these requests to

\footnotetext{
262 "Fort Riley Entering Era Of Greatest Growth," Junction City Union, 29 April 1955, 1; by 1959, that figure had risen to $\$ 100,000,000$ ("1958 Proves Successful Year at Fort Riley," The American Traveler, 5 January 1959, 8).

263 “Panel Okays Fort Riley Construction,” Junction City Union, 30 June 1955, 1.

264 “Defense Department Asks 11 Millions for Projects at Riley," Junction City Union, 20 April 1955, 1;

"Riley Funds Are Mostly For Housing," Junction City Union, 21 April 1955, 1.

265 Also during the period under study, minor construction occurred at other places on the installation, including upgrades to the water supply (new wells, lines, and treatment facilities), two storage igloos, three BOQs, and range storage buildings. There was also a large family housing program (Capehart), and several elementary schools were constructed.

266 “New Post Exchange Adds To Custer Hill Expansion Program," Fort Riley Post, 12 August 1960, 4.

267 “History of Fort Riley, Kansas," Record Group 77, Entry 242, Box 8, Folder: Armies \& MDW Comments, National Archives and Records Administration, College Park, MD.
} 
become reality. In 1959, the Custer Hill Chapel was completed; it was renamed Kapaun Chapel in 2001 in honor of Chaplain (Capt.) Emil J . Kapaun, who ministered to soldiers in WWII and the Korean War, where he became a POW.268

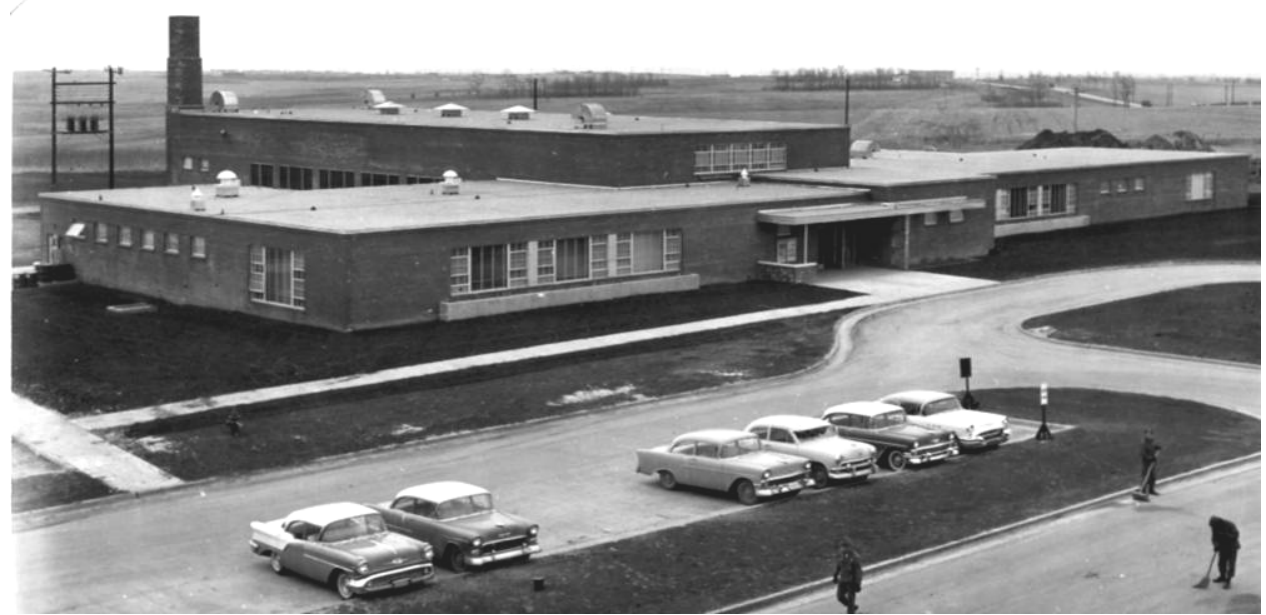

Figure 24. Enlisted Service Club at Custer Hill, 1965 (NARA).

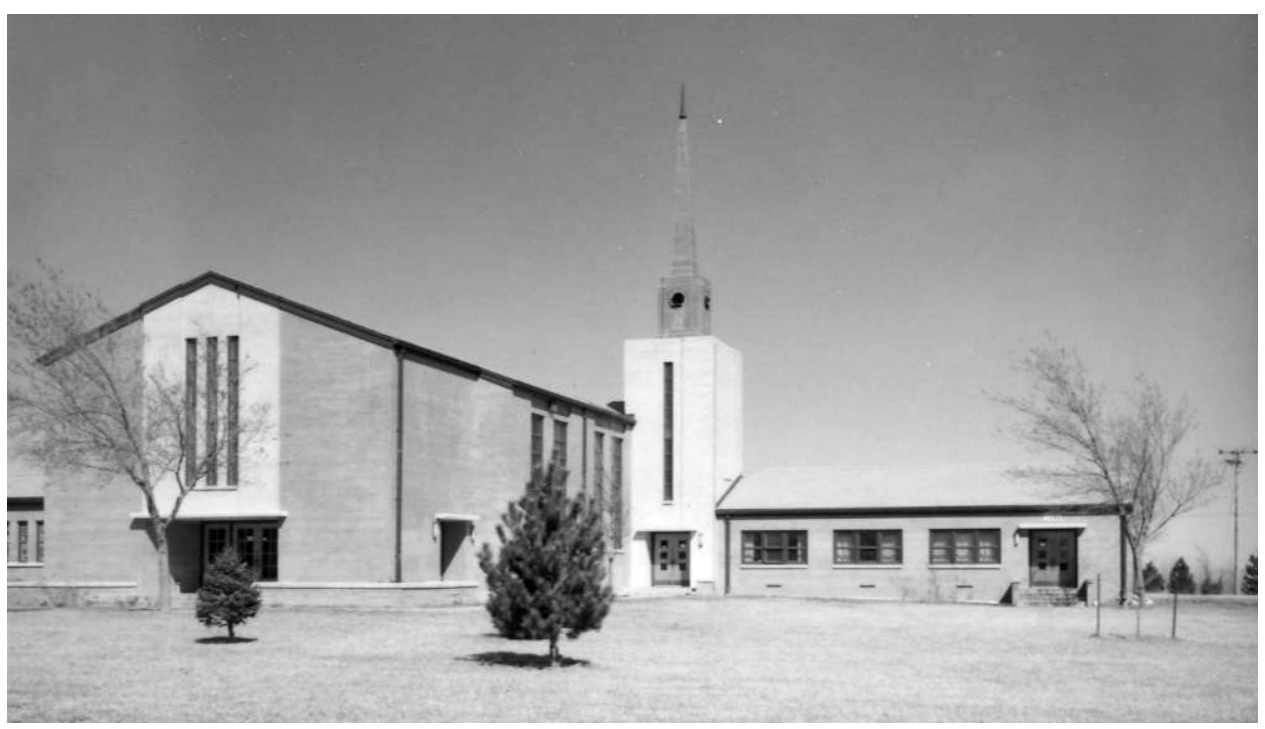

Figure 25. Custer Hill Chapel, 1968 (NARA).

The gymnasium opened in September 1960 and was named Craig Gymnasium in 1967 after General Malin Craig, a former Commandant of the Cavalry School who went on to become Chief of Staff of the U.S. Army. ${ }^{269}$ The

\footnotetext{
268 “Chapel Renamed for Hero," Fort Riley Post, 8 November 2001, 1.

269 Headquarters, Fort Riley, Kansas, General Orders Number 112, “Memorialization,” 5 May 1967, Vertical File, “Building 7024," Department of Public Works, Fort Riley, Kansas.
} 
facility contained a regulation basketball court with rollaway bleachers, two handball courts, and an exercise room. ${ }^{270}$ In lieu of a proper theater, the ballroom in the new service club fulfilled this function. The requested regimental headquarters, gymnasium, and theater received appropriations for their construction in J uly 1959, and were completed before the end of the 1960 calendar year (Figure 26, Figure 27, and Figure 28).271 In addition to new buildings, a nine-hole golf course was constructed at Custer Hill and dedicated in 1958.272

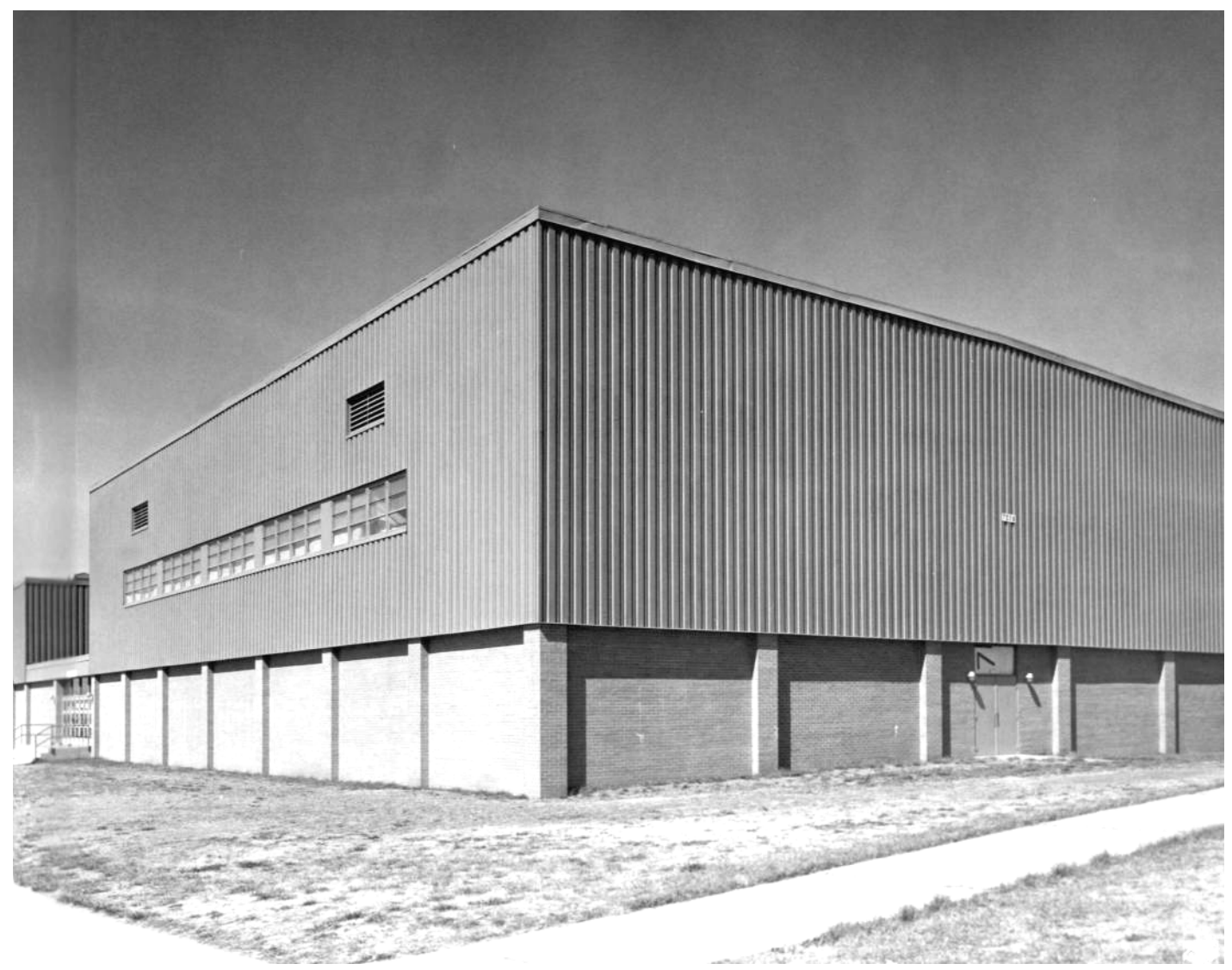

Figure 26. Craig Field House, Custer Hill, 1968 (Museum Division, Fort Riley).

270 “Col. Balliett Officially Opens Custer Hill Gym," Fort Riley Post, 16 September 1960, 9.

271 “1958 Proves Successful Year at Fort Riley,” 8.

272 Ibid. 


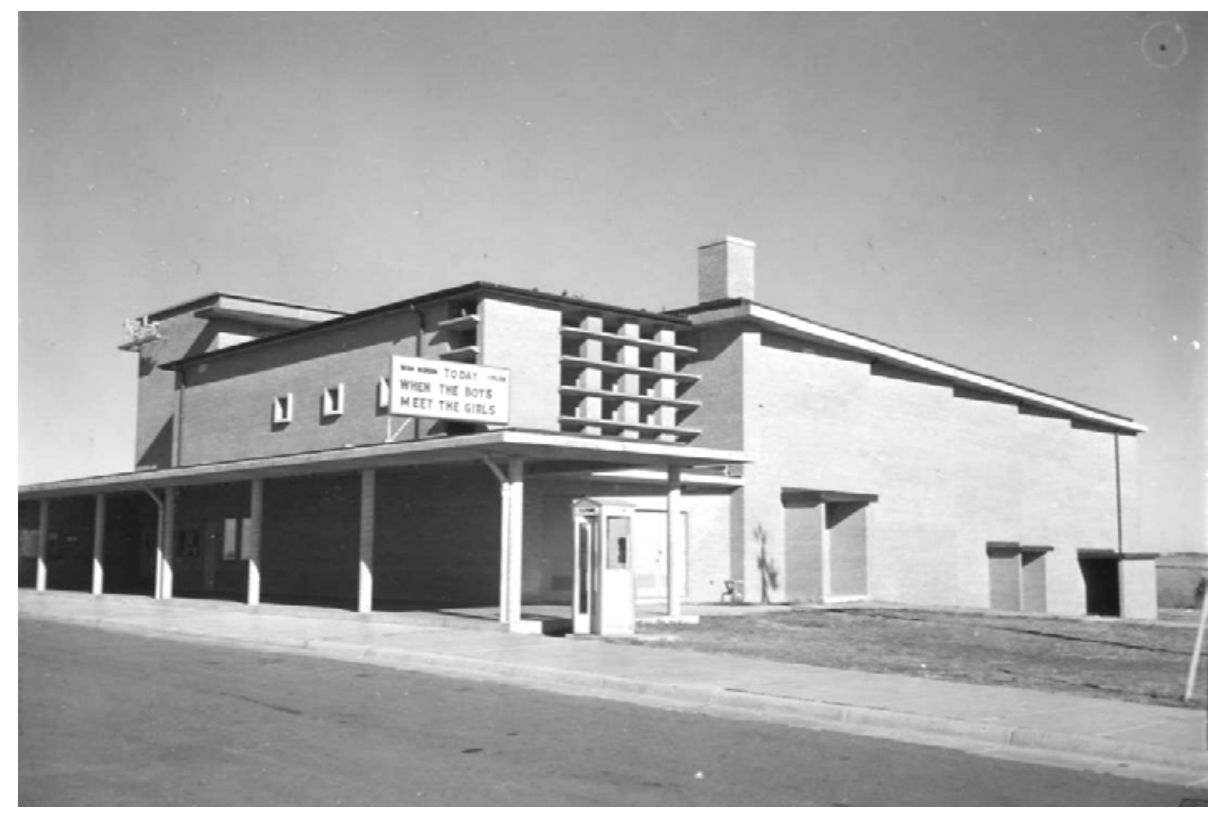

Figure 27. Theater \#5, Custer Hill, 1965 (NARA).

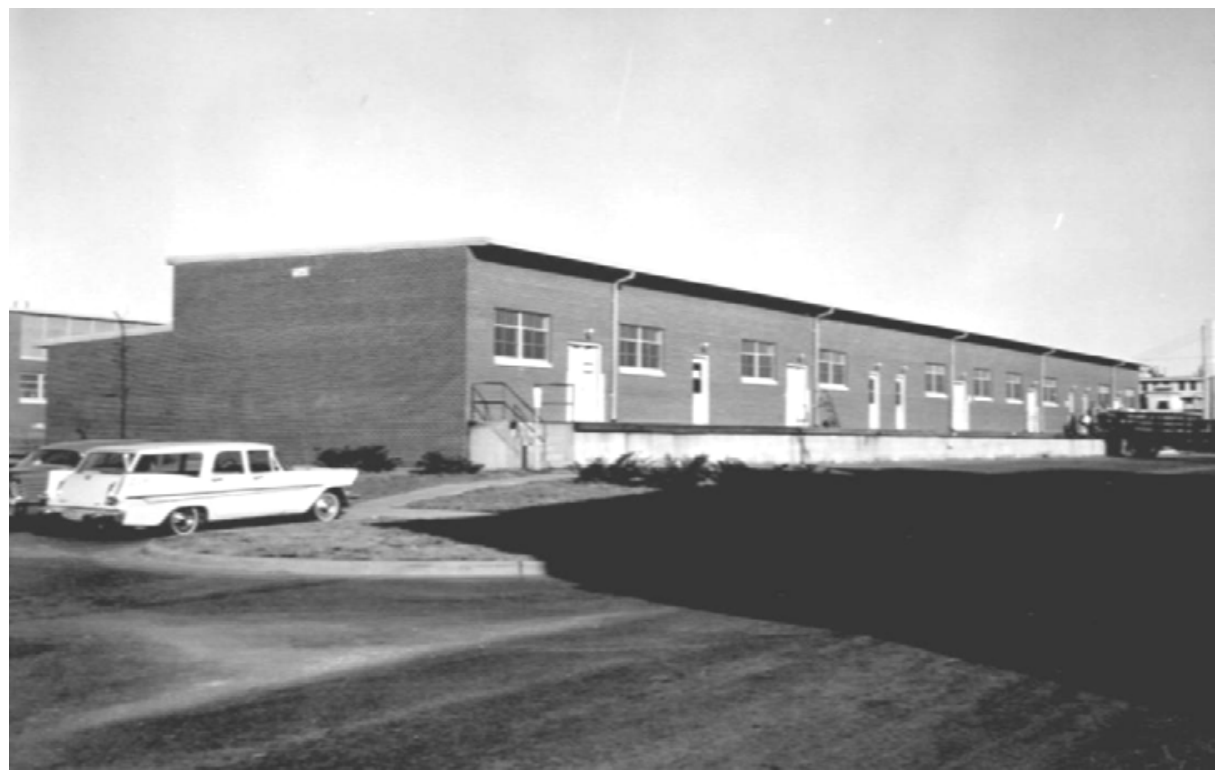

Figure 28. Administration/supply Building 7243, Custer Hill, 1965 (NARA).

By 1958, six more barracks had been completed in the Custer Hill area, with the now twelve total barracks providing housing for 3,366 men. ${ }^{273}$ The main inhabitants were the $16^{\text {th }}$ Infantry, the $18^{\text {th }}$ Infantry, and the $11^{\text {st }}$ Reconnaissance Squadron of the $4^{\text {th }}$ Cavalry. ${ }^{274}$ Designated "H-style,"

273 Department of the Army, "Construction Item Justification Data," (n.p., 25 April 1960), Record Group 77, Entry 203, MC Army PROG FLS BX 37-40, 54-62, Box 39, Folder: Medical, National Archives and Records Administration, College Park, MD; For more information on Army UPH designs and history (1950s - 1970s), see Kuranda, Unaccompanied Personnel Housing.

274 “1958 Proves Successful Year at Fort Riley,” 8. 
these two-company barracks were also built to a standard plan, with living areas on the vertical lines of the " $\mathrm{H}$ " and the horizontal connector holding the officer's quarters, laundry room, lavatories, dayrooms, lounges, mess halls and kitchens. 2751960 saw the completion of two additional barracks in a new style called "Rolling Pins" from the design with wider central block and narrower NCO quarters on the ends. The three-story barracks were built of brick and no longer contained company headquarters or mess halls; these were built as separate support buildings. Rolling Pin barracks were usually built in groups of five; each group had two mess halls, two administration buildings, and two supply buildings. Two groups could house a regiment. 276 The progress of construction across the site can be seen in Figure 29, with the Hammerhead barracks at the top, the H-style in the center, and the Rolling Pin barracks on the lower center. Also visible are the motor pools (Buildings 7165, 7168, 7173-7176), and support buildings including the theater (7285), the service club (7264), the gymnasium (7024), the administration/ supply (7243) and the chapel (7086).

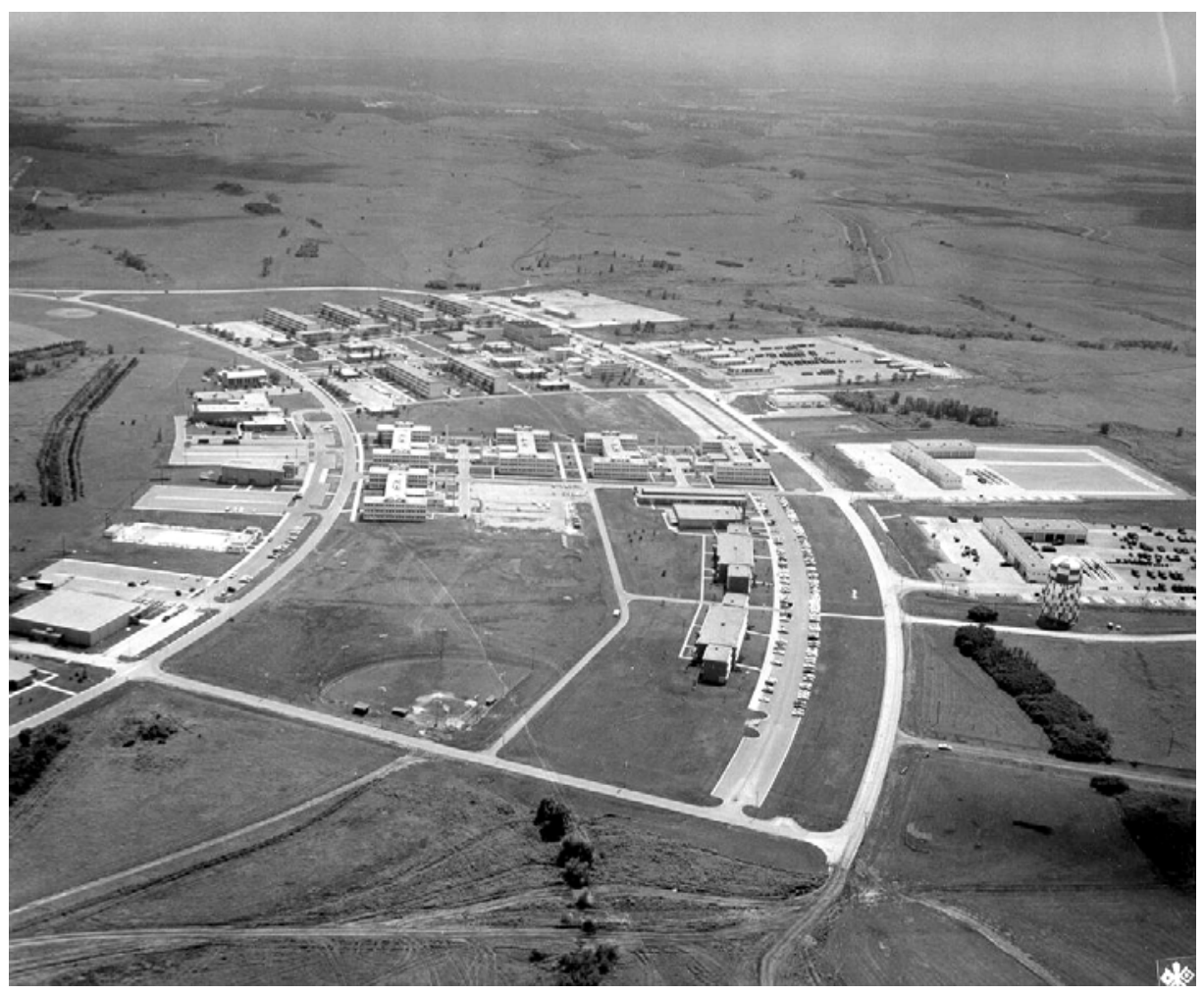

Figure 29. Custer Hill Troop Area, 1967 (Museum Division, Fort Riley).

\footnotetext{
275 R. Christopher Goodwin \& Associates, Inc., National Register Assessment of Buildings 7033, 7034, 7036, and 7215, Custer Hill Troop Area, Fort Riley, Kansas, (Frederick, MD: R. Christopher Goodwin \& Associates, Inc., 2007), 7; Kuranda, Unaccompanied Personnel Housing, 4-39 - 4-40.

276 Kuranda, Unaccompanied Personnel Housing, 4-59.
} 


\subsubsection{Army medicine}

Fort Riley has always played an important role in the development of Army medicine. Five Army Surgeon Generals served as medical officers at Fort Riley earlier in their careers. Additionally, the design and construction of Army medical facilities at Fort Riley covers practically all types of Army hospitals/ clinics developed during the period 1850- 1970.

\subsubsection{Early medical services and facilities}

Over the years, a series of medical firsts were established at Fort Riley. In the late 1880s, Post Surgeon J ohn Van Rennselaer Hoff organized the first company of instruction for the hospital corps. By 1896, the school was graduating two classes of enlisted men each year. The course later served as an example for Army medical schools. ${ }^{277}$ In 1902, the first large-scale Army maneuvers held in the United States occurred at Fort Riley, with the troops set up at what would later be Camp Whitside. During the maneuvers, the equipment for a field hospital and ambulance corps were tested, resulting in the third field hospital and ambulance company No. 3 being the first modern units of these types organized. ${ }^{278}$

The first hospital constructed at Fort Riley in 1853 was temporary in nature, as was the entire post. The wooden, one-story building with front veranda remained in use only until 1855, when permanent construction began at the post. Like the other buildings, the new hospital was constructed of limestone. The main section was two-stories high, with a one-story wing, and a wooden veranda on two sides of the structure. Shortly after a decision to expand the role of Fort Riley into a cavalry and light artillery school, plans were drawn up for a new, larger hospital. The second permanent Fort Riley hospital was constructed in 1888. Located north of the main post, the $\$ 300,000$ building had a two-story core and one-story wing. A mortuary, laundry, and steward's quarters were added to the complex by 1891. The old hospital was modified, a clock tower was added, and it became the cavalry administration building and post headquarters. 279

\footnotetext{
277 George E. Omer, Jr., “An Army Hospital: From Dragoons to Rough Riders - Fort Riley, 1953-1903," Kansas Historical Quarterly 23:4, Winter 1957, 21-22.

278 Ibid, 24.

279 Ibid, 3, 8, 18-20; the 1855 hospital is now the Post/Cavalry Museum.
} 


\subsubsection{Medical services and facilities for the World Wars}

Fort Riley hosted one of four Army medical officers' training camps from 1 J une 1917 until 4 February 1919. An academic staff of twelve provided instruction in both field classes, such as map reading, and classroom subjects including orthopedics, roentgenology (i.e., radiology employing $\mathrm{x}$ rays), and field sanitation. As part of this training camp, the first evacuation hospital in the United States was organized in 1917. Overall, the camp trained over 4,500 officers and 25,000 enlisted men. ${ }^{280}$

The establishment of a base hospital at Fort Riley during 1917- 1919 resulted in the utilization of more than 50 buildings for medical purposes, providing 3,000 beds. ${ }^{281}$ The peak usage of these facilities occurred in October 1918, with 11, 645 patients. In addition to war casualties, the patient volume was swelled with victims of the worst influenza pandemic that the world had seen (commonly known as the Spanish Flu). Fort Riley appears to have been the initial outbreak site in March 1918. Deploying soldiers then spread the illness to Europe, and it moved on across the globe. Returning soldiers in August and September 1918 ignited another wave in the United States. Fort Riley was hit hard, with 14,000 cases and 861 deaths the first three weeks of October. Overall, one-fifth of the world's population was infected and estimates range from 40-50 million dead. 282

After the war, the base hospital services returned to their pre-war configuration, and the medical staff was drastically reduced to four medical officers. Facilities and staff grew again in 1940-41 with the Army-wide expansion program gearing up for WWII. A new station hospital was begun in 1940, and opened in March 1941 at Camp Whitside. Final construction was completed in 1942. Built in the cantonment style with multiple ward and other specialized use buildings connected by covered walkways, the temporary facility was built to handle a 500-bed patient load. The total of eighty-four buildings covered eighty acres, including thirty-eight wards and eight barracks. The 1888 hospital became a surgical annex facility to the station hospital. In 1947, the annex was converted to Post Headquar-

\footnotetext{
280 George E. Omer, Jr., "An Army Hospital: From Horses to Helicopters - Fort Riley, 1904-1957," Kansas Historical Quarterly 24:1, Spring 1958, 3-4.

281 Ibid, 5.

282 “Pandemic," The Manhattan Mercury, 1 March 1998, n.p.
} 
ters for Fort Riley, and the station hospital became the main medical facility for the installation. 283

By 1953, Fort Riley was providing medical services on a regional approach, with military patients from Kansas, Nebraska, and the Dakotas. The temporary facilities of the station hospital were wearing out. At the same time, medical care began to rapidly increase in technological sophistication, bringing a need for more integrated physical facilities to incorporate these advances. Concurrently, a longstanding lack of funds for the Army Medical Department had resulted in a nationwide need for new hospitals. These two trends collided in the late 1950s, as evidenced by a call by Surgeon General Leonard D. Heaton for funding to speed up the hospital construction program, stating that "Modern medicine...can be practiced adequately only in modern facilities." 284 By 1959, the ambitious program to replace fifty-two Army hospitals in the United States had borne little fruit, with only ten hospitals completed and four under construction. ${ }^{285}$

\subsubsection{Irwin Army Hospital}

Fortunately for the inhabitants of Fort Riley, one of the ten was their new medical facility. Replacement of the station hospital was considered crucial for the expanding installation. A 250-bed hospital at Fort Riley was first announced by the Army Corps of Engineers in February 1953 with plans for the building to start during the summer of that same year after “.. sampling soils, core drilling, and securing other data necessary.....286 The site selected continued the trend of medical facilities in the Pawnee Flats area of the post, as the new hospital was placed on the western edge of the existing camp. ${ }^{287}$

Funding took longer to obtain, but work finally began two and a half years later as part of a larger building initiative on Fort Riley totaling \$10 million. ${ }^{288}$ Architectural plans for local siting were finalized in March 1955 by

\footnotetext{
283 Omer, "An Army Hospital: From Horses to Helicopters," 9, 13-14.

284 Rose C. Engleman, ed., A Decade of Progress: The United States Army Medical Department, 19591969, Chapter 3: "Modernization of Facilities and Equipment," (Washington, D.C.: Office of the Surgeon General, Department of the Army, 1971), 1. 285 Ibid.

286 “Plans To Build Hospital at Fort Riley Are on Schedule," Junction City Union, 25 February 1953, 1.

287 Omer, "An Army Hospital: From Horses to Helicopters," 10.

288 “Carlson Backs Military Building," Junction City Union, 12 July 1954, 1; “Fort Riley Entering Era Of Greatest Growth," Junction City Union 29 April 1955, 1.
} 
Associated Architects and Engineers of Wichita, Kansas with an estimated cost of $\$ 7$ million for the building. ${ }^{289}$ The Missouri River Division of the Corps of Engineers in Omaha was responsible for the bidding process and overseeing the construction of the hospital. Bids for the construction were accepted beginning on 10 May 1955, and were opened 21J une 1955 at 14:00 (2 p.m.) in the Geary County Courthouse in J unction City. Presiding was District Engineer Col. E.C. Adams of the Kansas City Corps of Engineer's office. ${ }^{290}$ Three bids were submitted by general contractors. Martin $\mathrm{K}$. Eby Construction Company of Wichita, Kansas won the contract with a bid of $\$ 5,488,116.30$, coming in under the $\$ 5.9$ million authorized for the project by the Corps of Engineers. ${ }^{291}$ The bid was approved and the contract was awarded on 29 J une 1955 with the work to be completed in 900 calendar days or 30 months. 292

On 19 July 1955 at 9:30 a.m., the groundbreaking ceremony marked the official start of construction. The first shovel of dirt was turned by Lieut. Col. Eleanor R. Asleson, chief nurse of the station hospital, with a silverplated spade that was also used for the groundbreaking of the Custer Hill housing project begun the same year. ${ }^{293}$ Presiding were Col. E.C. Adams, Martin K. Eby, Lt. Col. Clewis C. Moffett, Fort Riley post engineer, and other dignitaries including local leading citizens and military personnel. 294

The permanent hospital was planned as an L-shaped five-story reinforced concrete structure with brick facing and thermo pane windows with 250 beds, and based on a standard Army hospital design by York \& Sawyer of New York, New York (Figure 30). 295 The building plan was for approximately 190,000 square feet containing all hospital medical services and the necessary administrative offices. ${ }^{296}$ The plan was designed for expansion from the 250-bed structure to a 500-bed hospital if needed. For this reason, six elevator shafts were built into the building, but only three elevators were installed. ${ }^{297}$ Approximately half of the bed area and the entire

\footnotetext{
289 "Plans To Build Hospital at Fort Riley Are on Schedule," Junction City Union, 25 February 1953, 1.

290 “Wichita Firm Bids \$5,488,116 on Fort Riley Hospital," Junction City Union, 21 June 1955, 1.

291 "Fund of \$5,900,000 Assured for New Fort Riley Hospital," Junction City Union, 9 June 1955, 1;

“Wichita Firm Bids \$5,488,116 on Fort Riley Hospital," Junction City Union, 21 June 1955, 1.

292 “Wichita Firm Gets Contract For Hospital," Junction City Union, 29 June 1955, 1.

293 “Work Started on \$5,488,116 Fort Riley Station Hospital," Junction City Union, 19 July 1955, 1. 294 Ibid.

295 “Wichita Firm Gets Contract For Hospital," 1.

296 “Work Started On \$5,488,116 Fort Riley Station Hospital," Junction City Union, 19 July 1955, 1.

297 “Date Set for Hospital Bids," Junction City Union, 16 March 1955, 1.
} 
surgical wing were air conditioned, and heat was provided by gas with an oil standby in case of emergency. ${ }^{298}$ A dedicated boiler plant (Building $615)$ adjacent to the hospital was built concurrently. This reinforced concrete building cost \$656,115.299

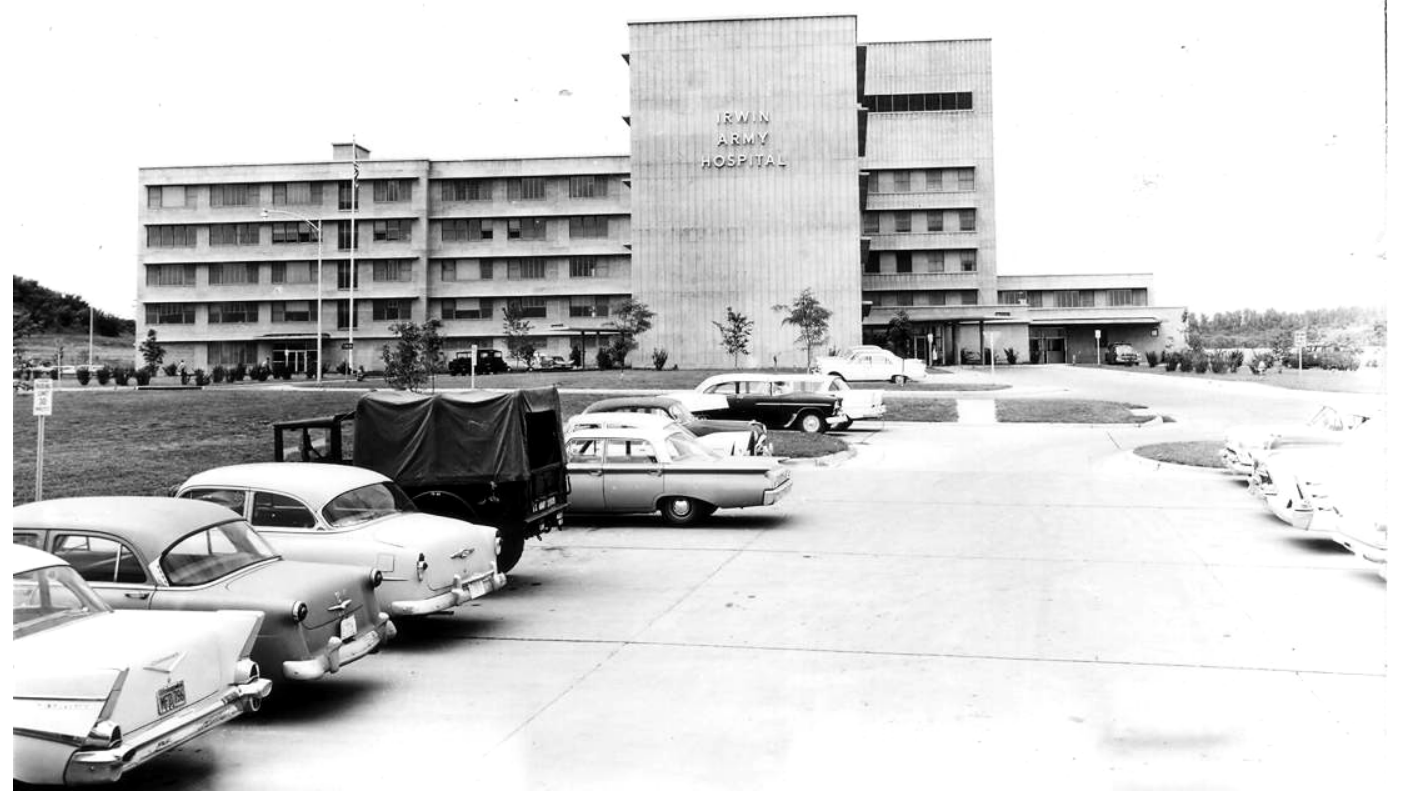

Figure 30. Irwin Army Hospital, Fort Riley, 1960 (NARA).

Construction of the state-of-the-art medical facility required over 43 million pounds of concrete for the 111'-tall building. The hospital boasted a pneumatic tube distribution-communication system with forty-two stations and an "audio-visual" call system enabling two-way conversation between patients and ward nurses (Figure 31). Bulk oxygen was piped into all critical medical treatment areas. To provide medical quality assurance, Maj. William J . Deragisch, medical service corps, served as project officer during the construction. 300

\footnotetext{
298 "Work Started on \$5,488,116 Fort Riley Station Hospital," Junction City Union, 19 July 1955, 1. 299 Fort Riley Department of Public Works, DA Form 2877, Real Property Record, Building 615, (Fort Riley, Kansas: Department of Public Works, n.d.).

300 Omer, "An Army Hospital: From Horses to Helicopters," 17.
} 


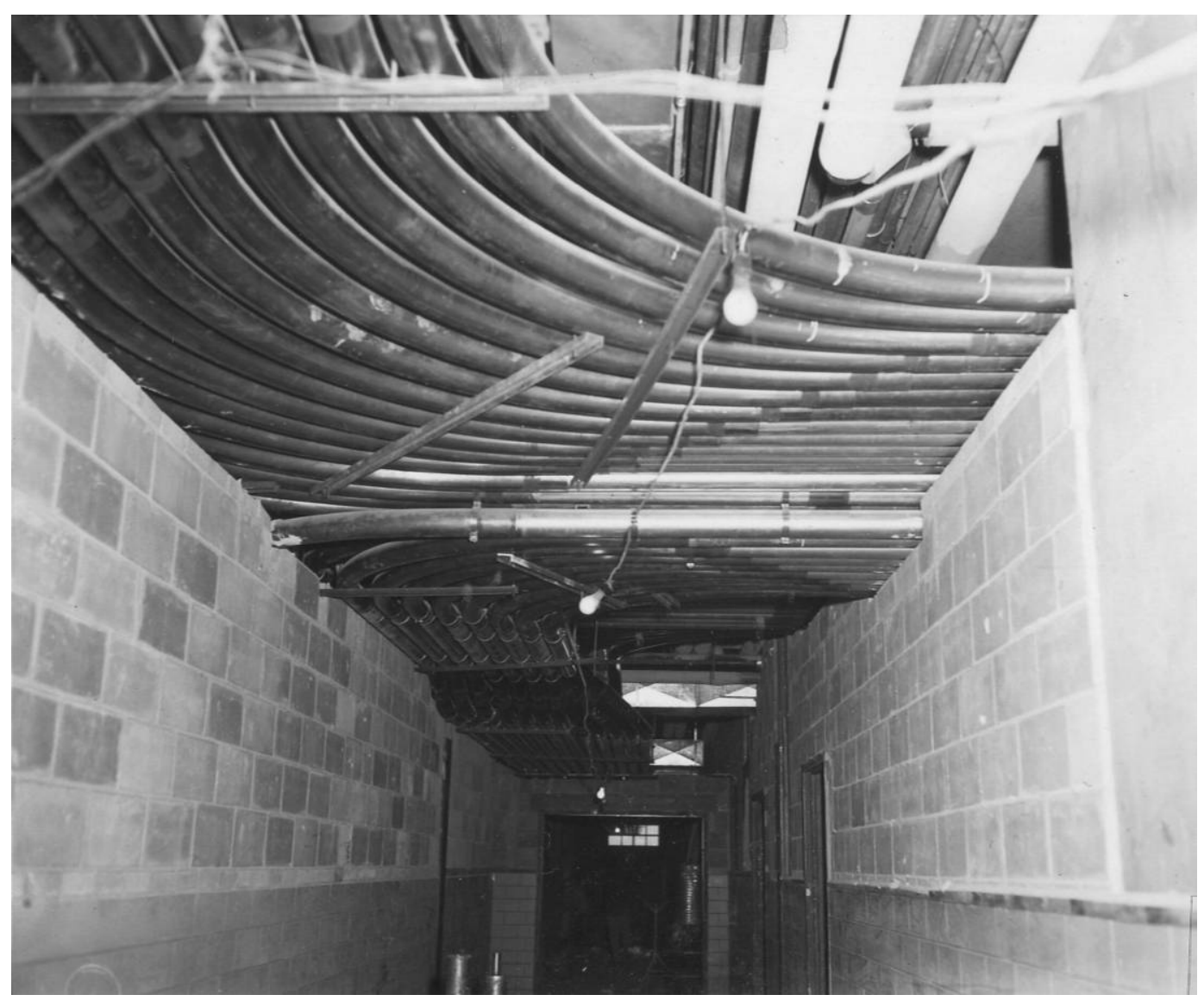

Figure 31. Pneumatic tube distribution/communication system, Irwin Army Hospital, Fort Riley, 1957 (NARA).

The hospital was dedicated on 7 February 1958 and named the Irwin Army Hospital after Brigadier General Bernard J .D. Irwin (Figure 32). ${ }^{301} \mathrm{Gen}$. Irwin had twice served as an Army surgeon at Fort Riley during the frontier days, when he accompanied, and sometimes led, mounted troops into battles with Indian tribes. In 1861, he led a mission to rescue an Army detachment trapped by Chiricahua Indians in Arizona. This act of bravery was the earliest occasion honored by bestowing the Congressional Medal of Honor, which Gen. Irwin received in 1894. ${ }^{302}$ Irwin had served as Post Surgeon in April 1866 until August 1867, and again from August 1871 until October 1873. After the Fort Riley assignment, he went on to become chief medical officer of the U.S. Military Academy, and medical director of the department of Arizona. 303

\footnotetext{
301 Under a recent policy (1957), all new Army hospitals were to be named after noteworthy Army Medical Department personnel (Engleman, Decade of Progress, Ch. 3, 4).

302 “1958 Proves Successful Year at Fort Riley," The American Traveler, 5 January 1959, 8.

303 Omer, Jr., “An Army Hospital: From Dragoons to Rough Riders,” 11, 13, 17.
} 


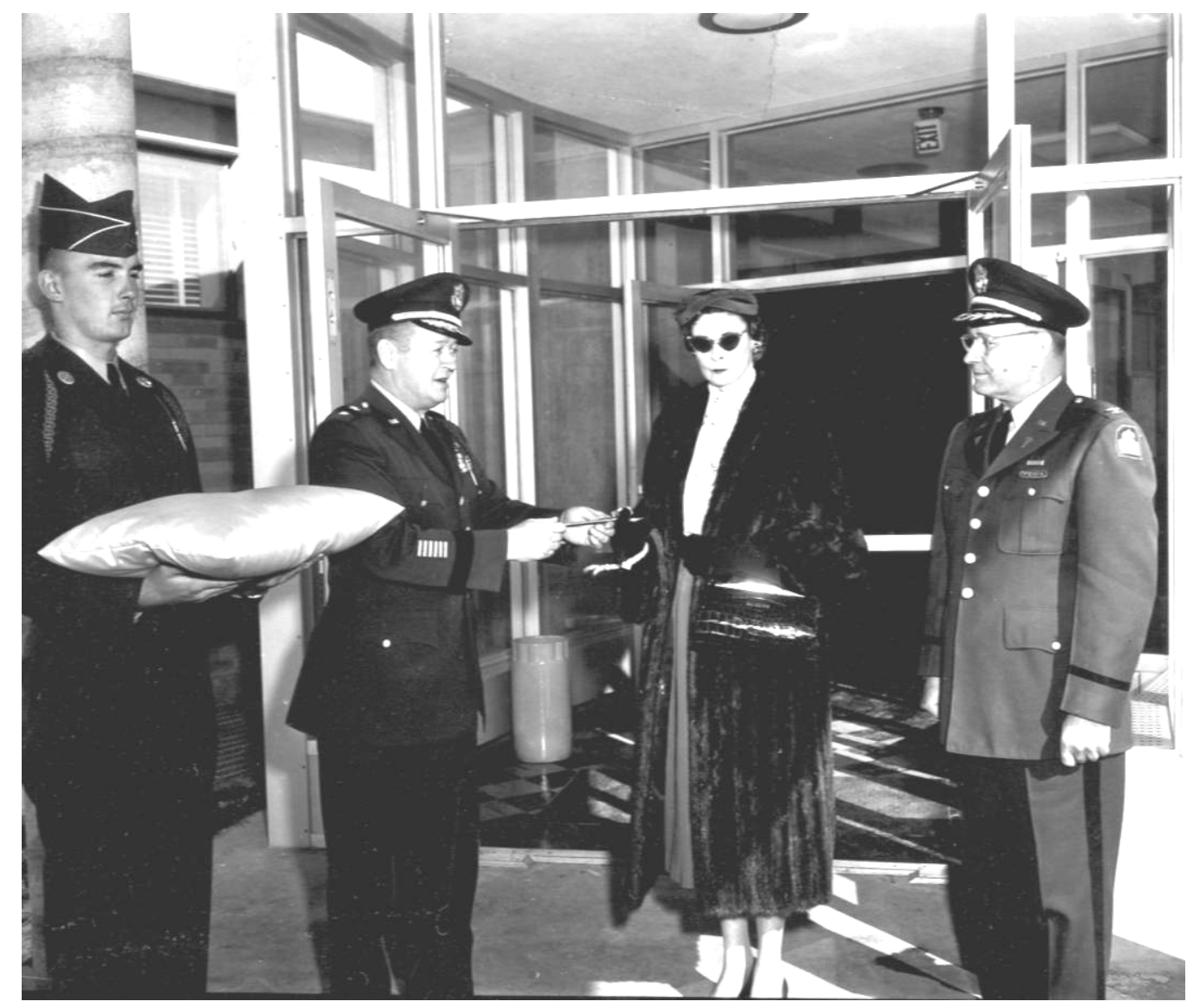

Figure 32. Mrs. Clara Irwin, granddaughter-in-law of Brigadier General Irwin, at dedication of Irwin Army Hospital, 7 February 1958 (NARA).

The FY 1957 construction program included a nurses' BOQ and enlisted men's barracks at the new hospital, completing the complex. Irwin Army Hospital celebrated its second birthday in February 1960 with an open house and guided tours. Visitors saw the occupational therapy, physical therapy, kitchen, and dining areas. In its first two years of operation, there were over 15,000 patient admissions, 247,000 outpatient treatments, and 1,891 baby deliveries. ${ }^{304}$

\subsubsection{Army aviation}

\subsubsection{Expansion of Army aviation}

Once up and running, the Army aviation program grew rapidly during the mid- and late-1950s. Due to the gradual withdrawal of the Air Force from primary flight training for the Army, the facilities at Fort Sill rapidly grew overcrowded and the School was moved to Fort Rucker, Alabama in 1954. 
In J uly of that year, the Transportation School began training mechanics for field maintenance duties. ${ }^{305}$ Weapons development resulted in armed helicopters by the end of the decade, initiating a series of changes to Army organization and doctrine with the creation of an air cavalry. No longer consigned to support roles, the air units would be utilized as a combat resource, providing "dedicated airmobile transport, supply, and fire-support assets." ${ }^{306}$ A construction program was begun to provide facilities for the air cavalry units; it focused on two standard Army aviation hangars (OCE 39-01-62 and 29-01-64), one containing 12,000 square feet, the other 20,000.307 Aircraft design continued to evolve, and the UH-1("Huey") utility helicopter went into service transporting small units and medical evacuees, and providing firepower as a gunship. The H-37 and the later HC-1 provided greatly increased cargo loads. 308

The air mobility concept developing within Army aviation was a good fit with the Pentomic Army reorganization. The new helicopters provided a new weapons platform for close support of ground troops and personnel movement enhancing the greater maneuverability of the Pentomic units. Fixed-wing planes were also undergoing development that would come to fruition in the early 1960s with improved pay load limits, short take-off and landing abilities, and expanded surveillance capabilities. ${ }^{309}$

New aircraft and higher levels of fleet inventory resulted in significantly increased training demands for pilots and mechanics. By the beginning of 1957, all Army aviation training had transferred to Army control under the Continental Army Command (CONARC). 310 Most courses were eventually consolidated at the Army Aviation School at Fort Rucker, with primary helicopter training conducted at Camp Wolters, Texas. The school at Fort Rucker continued to grow over the late 1950s, with new facilities, courses, and equipment, including instruction necessary for pilots to gain instrument qualification.

\footnotetext{
305 Richard P. Weinert, Jr., A History of Army Aviation - 1950-1962, (Fort Monroe, Virginia: Office of the Command Historian, U.S. Army Training and Doctrine Command, 1991), 268.

306 Michael A Pedrotty, Julie L. Webster, Gordon L. Cohen, and Aaron R. Chmiel, Historical and Architectural Overview of Military Aircraft Hangars: A General History, Thematic Typology, and Inventory of Aircraft Hangars Constructed on Department of Defense Installations, (Langley AFB, VA: HQACC, September 1999, Revised May 2001), 5-18.

307 Ibid.

308 Weinert, History of Army Aviation, 270.

309 Office of the Chief of Military History, The Army and The New Look, 26:14.

310 Weinert, History Of Army Aviation - 1950-1962, 228.
} 


\subsubsection{Post-Korean War development of Marshall Field}

Thanks to conflict-driven innovations in flight and cargo hauling operations, helicopters assumed a much larger peacetime Army role after the Korean War. Fort Riley was an early beneficiary of the helicopter's increased importance in post-Korea air missions, becoming home to the $5^{\text {th }}$ Army's first helicopter training facility. The $328^{\text {th }}$ Helicopter Cargo Transportation Company and the $138^{\text {th }}$ Helicopter Cargo Transportation Field Maintenance Detachment were activated at Marshall Field in J uly 1953.311

Within a year, the helicopter unit at the field had been increased to a Battalion. The units were quartered at Marshall Field where they received both practical and classroom training on rotary-wing craft. On 19 November 1953, the first three Sikorsky H-19-D helicopters purchased by the Army arrived fresh from the factory to be used in training at Marshall Field. 312 This training included demonstrations of cargo delivery in support of infantry battle exercises. Periodically, the Marshall Field units would participate in large-scale exercises in other parts of the country, such as "Operation Flash-Burn" at Fort Bragg, North Carolina in the spring of 1954 where they performed maintenance duties on airplanes taking part in the exercise. The 98 th Transportation Army Aircraft Repair Detachment at Fort Riley was the only unit of its type in the 5th Army area in 1954, and serviced all of the planes for the region. Working largely in Marshall Field hangars, the unit worked primarily on engines, instruments, and rigging. 313

Around the same time, the 328 $8^{\text {th }}$ Helicopter Transportation Company transferred overseas, and the $21^{\text {st }}$ Transportation Helicopter Battalion was activated at Marshall Field. The first unit of its kind in the Army, the battalion's mission was to "activate, supply, and supervise training of helicopter companies to prepare them as combat ready units for assignment overseas or with units in the United States."314 The necessary technical personnel were gathered from various technical and special schools across the country. Trainees spent approximately three months at Marshall Field before being field tested and given new assignments.

\footnotetext{
311 "Transportation Corps to Observe 11 ${ }^{\text {th }}$ Anniversary," Junction City Union, 30 July 1953, n.p.; "Copter Unit To Fort Riley," Junction City Union, 31 July 1953, 1.

312 “Three of 18 New Helicopters On Order Delivered," Junction City Union, 19 November 1953, 1. 313 “Fort Riley Army Air Repair Group Will Go to Bragg," Junction City Union, 23 March 1954, n.p. 314 “Helicopter Battalion To Be Activated Soon," Junction City Union, 14 July 1954, 1.
} 
Advancements in military aircraft and airborne combat tactics kept the units at Marshall Field supplied with new machines, new units, and new training courses. By March 1955, the 71st Helicopter Transportation Battalion was training pilots in the operation of twin rotor helicopters, first the Piesecki H-25-A, then the larger H-21-C. The three-week course included eighty hours of class work and twenty-five hours of flying time, and consisted of twelve officer or warrant officer pilots on average. Flying time included takeoffs and landings in confined areas, and lifting cargo loads slung below the helicopter (Figure 33). To keep the equipment operative, the 80th Transportation Cargo Helicopter Field Maintenance Detachment worked around the clock. ${ }^{315}$

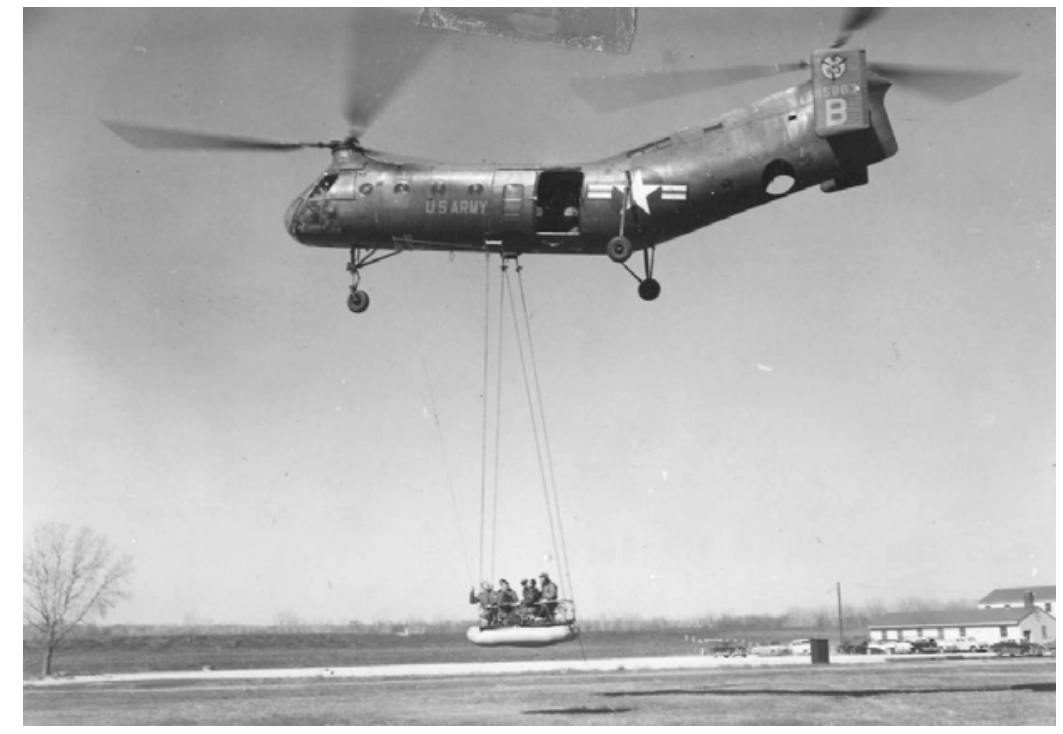

Figure 33. Cargo helicopter training at Fort Riley, 1956 (NARA).

The emphasis on helicopters did not result in neglect for fixed-wing aircraft at Fort Riley. The post was selected as the home of the 14th Army Aviation Company in J une 1955. Activated as a Fixed-Wing Tactical Transport unit, it was the first of its type and flew the 14-seat DeHaviland U-1 Otter, designed to haul cargo and passengers in and out of confined areas. ${ }^{316}$

Big news arrived on 21J uly 1955, with receipt of a directive to activate the first Army Aviation Unit Training Command (AAUTC) at Fort Riley. The creation of the AAUTC was the result of the rapid expansion in Army avia-

\footnotetext{
315 "Helicopter Pilots Train at Fort Riley Where Cavalry Units Once Were Supreme," Junction City Union, 18 March 1955, 5.

316 “New Air Unit Sent to Post," Junction City Union, 2 June 1955, 1.
} 
tion units in the mid-1950s. Seeking to utilize existing resources, the Department of the Army established two AAUTCs in 1955: one at Fort Riley and one at Fort Sill. The 71st Transportation Battalion was assigned the training mission on $24 \mathrm{~J}$ anuary, and the AAUTC became operational on 18 February, making it the first of its kind in the Army. The Fort Riley AAUTC was tasked with activation and training units on twin-rotor and fixed-wing aircraft. The Fort Sill counterpart, activated 1J uly 1955, activated and trained units on single-rotor helicopters. ${ }^{317}$

The shift from training individual pilots to entire units resulted in equipment and facility shortfalls that had a detrimental effect on the AAUTC program. Aircraft were slow in arriving from the factories, it took time to train mechanics to keep the increased number of aircraft in operating condition, and increased numbers of units to be trained put too much strain on the system. Additionally, Fort Riley had training facility limitations, remediation of which would take time to get through the construction cycle. By October 1957, the Department of the Army agreed to temporarily suspend the unit activation schedule in an attempt to let men and material catch up to requirements. ${ }^{318}$

By 1958, Marshall Field was home to the AAUTC, the 80th and 81st Transportation (Helicopter) Companies, and the 1st Infantry Division's 1st Aviation Company (Figure 34). ${ }^{319}$ The duties of the units involved training, air support of the 1st ID, or humanitarian missions. Change was in the air, however, as troop restructuring in 1958- 59 led to a decreased number of aviation units. As a result, both AAUTCs were discontinued in fiscal year 1959.320 By 1960, the activities at Marshall Field were largely back to aircraft maintenance and support of $5^{\text {th }}$ Army aviation programs.

\footnotetext{
317 Weinert, A History Of Army Aviation, 231; “Army Orders Air Training Unit at Post,” Junction City Union, 21 July 1955, 1.

318 Weinert, A History Of Army Aviation, 234, 271.

$3191^{\text {st }}$ Infantry Division and Fort Riley Information Office, First Infantry Division Yearbook: 41st Anniversary, 1917-1958, n.p.

320 Weinert, A History Of Army Aviation, 234, 271.
} 


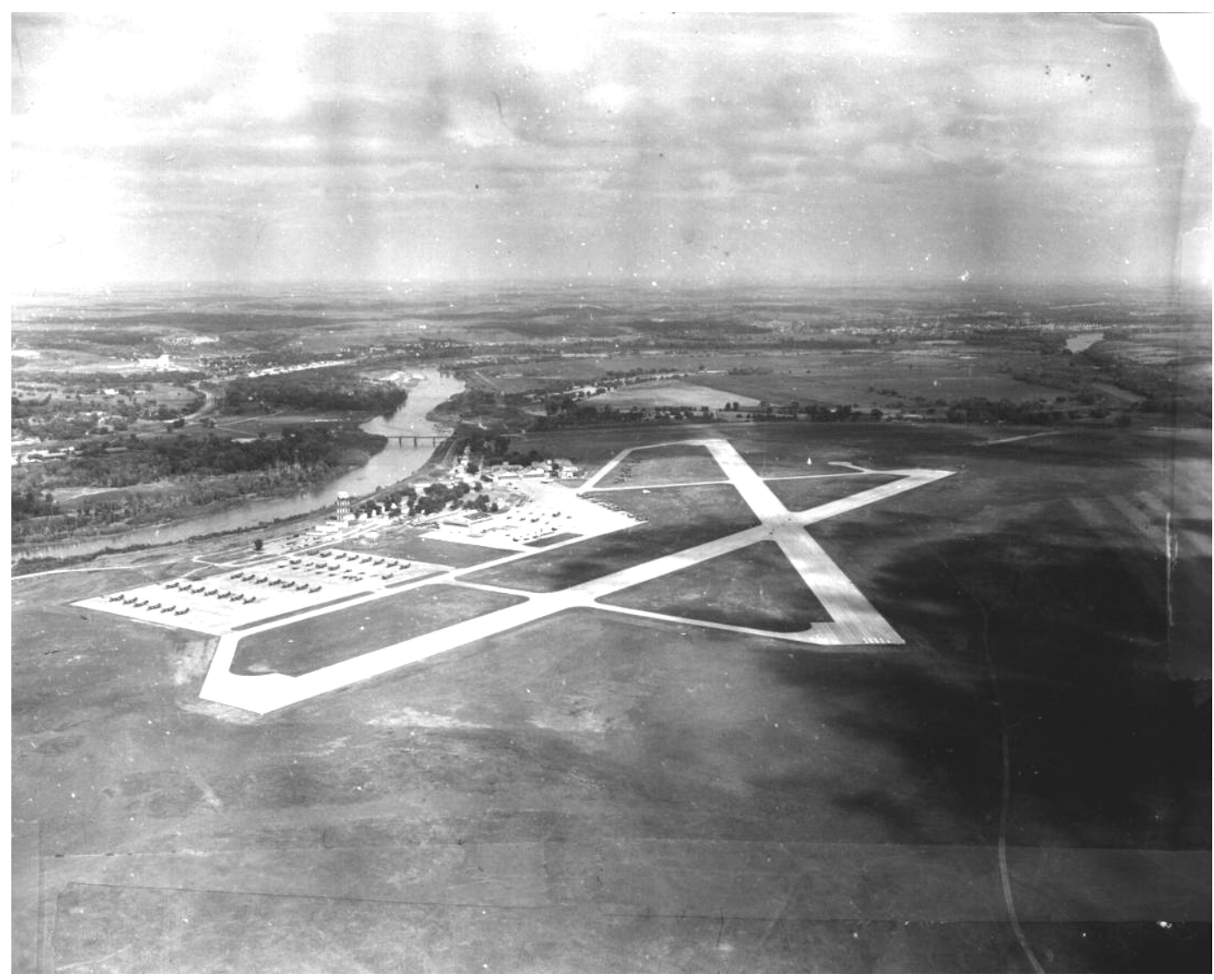

Figure 34. Marshall Army Air Field, 1957 (Museum Division, Fort Riley).

As the activity at Marshall Field increased with the emphasis on helicopters, the air cavalry/ Pentomic mobility concept, and the stand up of the AAUTC, new construction to provide adequate facilities was requested and funded. By April 1955, a budget request for a new hangar was in place at an estimated cost of $\$ 449,000 .{ }^{321}$ Two maintenance hangars (Building 727 and Building 723) opened for business in 1957 and 1959, respectively. Building 727 was built as a helicopter hangar complete with hardstand for maintenance on the 23 aircraft assigned to one Light Cargo Helicopter Company. Building 723 was requested in 1956 to provide field maintenance facilities for 74 aircraft. ${ }^{322}$ In 1960 , the field received a new simulation training building (\#720) and a new administrative building (\#725). The flight simulator building contained six link trainers in addition to classroom and office space, and was requested in 1957 specifically as a result of increasing training demands. The operations building was re-

\footnotetext{
321 “Riley Funds Are Mostly For Housing," Junction City Union, 21 April 1955, 1.

322 Department of the Army, “Construction Item Justification Data," (n.p., 1 Sep 1956), Record Group 77, Entry 242, Box 7: FY 1958, Folder: Justification Book 1956, National Archives and Records Administration, College Park, MD.
} 
quested in 1957 as necessary for the administrative and operational functions of a Helicopter Company and would directly support the new hangar (Building 727). ${ }^{323}$ Utilities were upgraded with a water treatment facility (Building 721) in 1957, a generator house (\#745) in 1958, and another (\#747) in 1960.

\subsection{Army reorganizes and gets combat-ready}

\subsubsection{Mission requirements}

With the arrival of the Kennedy administration in early 1961, the military began to grow again. Heightened tensions between the U. S. and the Soviet Bloc had led to a need for increased strength, and more efficient troop mobilization and management to assure preparedness for any eventuality with the ability to provide a flexible response. The 1961 troop build-up to counteract the Soviet aggression in Berlin persisted after the crisis passed. During that year, Army strength went from 860,000 to 1,060,000, and settled the next year at a permanent strength of $970,000.324$

The Strategic Army Corps (STRAC) had been established in 1958 to provide an easily deployable, flexible strike force capable of responding without declaration of an emergency. The first STRAC units were the XVIII Airborne Corps at Fort Bragg; it shortly became comprised of the 4th ID at Fort Lewis, the 82nd Airborne Division at Fort Bragg, and the 101st Airborne Division at Fort Campbell. The 1st ID at Fort Riley was designated a back-up unit. Airlift assets were made available to the units, which were required to maintain instant combat readiness; their slogan was "Skilled, Tough, Ready Around the Clock." 325 In February 1962, the STRAC increased from three to eight divisions, including the 1st ID at Fort Riley. In addition to active units, this new structure included National Guard divisions with the regular Army divisions. This was the first time Army National Guard and Reserve units were assigned to a strategic strike force in peacetime. ${ }^{326}$ It also put the Air Force 388th Tactical Fighter Wing from McConnell AFB as a joint fighting division of the 1st ID. ${ }^{327}$ The STRAC

\footnotetext{
323 Department of the Army, "Construction Item Justification Data," (n.p., 15 Nov 1957), Record Group

77, Entry 242, Box 8: 1958 FY, Folder: Item Justification, National Archives and Records Administration, College Park, MD.

324 Hermes, "Global Pressures and the Flexible Response," 606.

325 “STRAC," 1st Battalion, 22nd Infantry, Fort Lewis, Washington website (http://1-

22infantry.org/history/pentonic/htm).

326 “First Div. Became STRAC Last Friday," The Fort Riley Post, 2 March 1962, 1.

327 "Air Force Wing to Support Division," The Fort Riley Post, 22 March 1963, 8.
} 
and elements of the Tactical Air Command were combined to form the U.S. Strike Command (STRICOM) in 1961. ${ }^{328}$ This unified command was tasked with responding to a global crisis.

New equipment and weapons were also part of the increased strength. The Army's emphasis on "dual capability" weapon systems sought to provide readiness in all types of war styles from limited to all-out general war, for nuclear and non-nuclear conflicts, for traditional troop and armored weapon warfare to guerilla warfare. ${ }^{329}$ Southeast Asia, as well as other areas of the world, showed the needs for limited and guerilla warfare techniques and capability. ${ }^{330}$ The Special Forces units were expanded as an answer to this growing threat. ${ }^{331}$

President Kennedy announced Reorganization of Army Divisions (ROAD) in May 1961, to be implemented starting in 1962. ROAD brought about a new division, the Mechanized division (added to the existing typesInfantry, Armored, and Airborne) and created a four-unit structure. This changed the divisional structures from Pentomic (with each division having five battle groups) to four divisions with a common base, but with varying types of battalions-such as Infantry, Mechanized, Tank, or Parachute-depending on location and mission. ${ }^{332}$ This supported both the mobility of Army units and dual-capability forces, and supplanted the STRAC, which ended in 1962. ${ }^{333}$

The 1st Armored and the 5th Infantry (Mechanized) were the first units reorganized under the ROAD concept. After successful testing, the Army expanded the program in 1963-64, including the remaining 14 active divisions and a reorganization of the National Guard and Army Reserve divisions as well. ${ }^{334}$

It was not until December 1964 that the 1st Infantry demonstrated ROAD at Fort Riley when 75 general officers of the Army and Air Force Head-

\footnotetext{
328 “First Division Units Training at Pike National Forest," The Fort Riley Post, 9 November 1961, 12. 329 “Army Stresses New Weapons Concept in 60," The Fort Riley Post, 6 January 1961, 13.

330 "Why All The Emphasis On Guerilla Warfare," The Fort Riley Post, 16 March 1962, 7.

331 "Strength Buildup Head the List of 1961 Military News Events," The Fort Riley Post, 29 December 1961, 7.

332 "Army Organization First ROAD Type Divisions," The Fort Riley Post, 2 February 1962, 9.

333 "STRAC," (http://1-22infantry.org/history/pentonic/htm).

334 Hermes, "Global Pressures and the Flexible Response," 610.
} 
quarters from all over the United States viewed a demonstration by the "Big Red One" showcasing it as a combat-ready "ROAD Infantry Division Tailored for Airlift and Surface Movement. "335 Demonstrations of personnel, equipment, engineering, and techniques were displayed to U.S. Army officers and politicians, as well as officers from foreign allies. ${ }^{336}$

\subsubsection{Combat-ready training}

Until September 1961, the 1st ID continued with its mission of recruit training. As geo-political events escalated that month, President Kennedy required the division to become "combat ready." This shifted the mission from recruit training to strengthening the division and began an intensified combat training program. 337

Before September 1961, Fort Riley continued providing training for a range of soldiers from new recruits to NCOs. The current emphasis on mobility led to new systems of troop rotation and deployment. Basic training was essentially the same as it had been during the 1950s. The induction started for a new recruit at the Reception Station at Camp Whitside where they were processed, underwent an initial medical examination, and were issued their new clothing and bedding. This was where they also received their first Army meal before being taken to their quarters. Over the next three days, the receptees received a complete physical examination, underwent a series of tests, and were educated in Army methods and oriented on what was expected of them in their Army career. 338

More than 1,000 of the recruits that came to Fort Riley at the end of 1960 and beginning of 1961 were ultimately sent to South Korea by May 1961. Their training consisted of the standard eight-week basic training and then on to training specifically for either heavy weapons specialists or to a rifle platoon. This training began to incorporate new infantry weapons: the M14 rifle and the M-60 machine gun. 339 The introduction of the $\mathrm{M}-14$ rifle in 1961 provided a major advancement over the previous rifle, the M-1.340

\footnotetext{
335 “75 Generals to Visit Post," The Fort Riley Post, 11 December 1964, 1.

336 “Foreign Officers To Visit Fort Riley," The Fort Riley Post, 16 August 1963, 1, 2.

337 "Strength Buildup Head the List of 1961 Military News Events," The Fort Riley Post, 29 December 1961, 7.

338 “First Receptees Arrive At Fort Riley's New Reception Station For Processing," The Fort Riley Post, 6 January 1961, 1.

339 “Army Stresses New Weapons Concept in 60," The Fort Riley Post, 6 January 1961, 13.

340 “Army Reviews Its Top Stories In 1961 News," The Fort Riley Post, 29 December 1961, 7.
} 
The M-14 was automatic, more field serviceable, more accurate, and had increased firepower. ${ }^{341}$ Rifle training methods continued to be focused on the TRAINFIRE system, with several ranges in place by the early 1960s. ${ }^{342}$

The recruit's final training periods focused on how to apply their separate skills as a unit. ${ }^{343}$ The unit training was part of a new U.S. Army mobilization program called the Overseas Unit Replacement Program (OVUREP). The new system was designed to provide troops deployed to South Korea with increased morale and lower transport costs by deploying entire units instead of individual replacements. ${ }^{344}$ The First Infantry, the Second Infantry of Fort Benning, GA, and the 2nd Armored Division of Fort Hood, TX were the first U.S. Army units under the OVUREP system in 1961.345 The 12th and 8th Infantry were the first through this system from Fort Riley, but all installation infantry groups ultimately participated. ${ }^{346}$ OVUREP proved successful as a concept, but difficulties arose in meeting contingencies, and the program ended with the flare-up of tensions over the Berlin Wall. ${ }^{347}$

The Noncommissioned Officer Academy was opened in 1955 for training of 5th Army NCOs with courses in Leadership and Training Methods. Basic and Duration of the senior curriculum courses ranged from two to nine weeks, with a capacity of 150 students per course. ${ }^{348}$ Starting in 1961, Air Force personnel were also trained at the Fort Riley NCO Academy. ${ }^{349}$ In the summer of 1964, the school was reorganized to become the only accredited NCO academy in the 5th Army. 350

The First Division Signal School, organized in J anuary 1962, trained 1,000 students in its first year in communications technology including radio

\footnotetext{
341 “Army’s Marksmanship Program Under Study,” The Fort Riley Post, 21 July 1961, 3.

342 Headquarters, United States Continental Army Command, Letter to Deputy Chief of Staff for Logistics, National Archives.

343 “First Cycle Over For 12th Infantry Recruits," The Fort Riley Post, 10 February 1961, 1.

344 John R. Brinkerhoff, “A history of unit stabilization,” Military Review, May-June, 2004.

345 “'Red One' and Two Other Divisions will Convert To Combat Ready Units," The Fort Riley Post, 11 August 1961, 1.

346 "8th Infantry Trainees Enter Final Phase of Training Before Overseas Shipment," The Fort Riley Post, 20 January 1961, 1.

347 Brinkerhoff, John R. “A history of unit stabilization.” Military Review, May-June, 2004

348 "Many Post Units Conduction Schools in Special Skills," The Fort Riley Post, 22 September 1961, 3.

349 “Air Force Personnel Training At Fort Riley NCO Academy," The Fort Riley Post, 9 November 1961, 4.

350 “NCO Academy To Train Area Students," The Fort Riley Post, 11 September 1964, 6.
} 
telephones, wireman-switchboard, radio teletype operations, and communications center-teletypewriter operations. The classes at Fort Riley were from two to sixteen weeks, one-half the time for the classes at the Army Signal Schools. 351

Fort Riley was the site of a large annual Reserve Officers Training Corps (ROTC) encampment and training school. Each summer Fort Riley hosted cadets from the thirteen-state 5th U.S. Army area for six weeks of practical training in everything from infantry weapons to "bivouac problems" which complimented the military science course at their schools. ${ }^{352}$ Training support was provided by the 13th Infantry and 1st Division units with between 300 to 425 officers and enlisted men serving as instructors and trainers in every branch specialty. By 1963, there were over 2,500 ROTC cadets. 353

Additionally, Fort Riley continued to support annual two-week training cycles for National Guard and Reserve troops. ${ }^{354}$ The National Guard was an integral part of the quick mobilization systems of the Army as well as filling in the ranks when needed. Army Reservist and National Guardsmen shared equipment and maintenance facilities with active Army members and went to active Army schools for training. ${ }^{355}$ In 1961, this plan of integration of the National Guard and Reserve was recommended at the One Army conference. The call-up for National Guard and Reserve in 1961 was the biggest to date with 155,000 reservists called to active duty. ${ }^{356}$

In order to remain combat-ready, the STRAC units (and later ROAD divisions) required near-constant training, most commonly through maneuvers and exercises both individually at home bases, and in combined forces. Participation ranged from a few officers up to a number of battalions plus support, but all involved movement of troops on post or to bases around the United States as well as overseas. On 27-29 J anuary 1961, eighty-one officers and forty-eight enlisted men from Fort Riley partici-

\footnotetext{
351 “First Division Signal School," The Fort Riley Post, 21 September 1962, 13.

352 "Fort Riley Will Host the Largest ROTC Summer Encampment in the Nation," The Fort Riley Post, 16 June 1961, 8.

353 The numbers of ROTC cadets training at Fort Riley were-1961=1,550; 1962=1,400; 1963=2,400; 1964=1,900 (“1,900 ROTC Cadets To Train at Fort Riley,” The Fort Riley Post, 13 February 1964, 1).

354 "Post Will Again Support Summer Reserve and National Guard Training," The Fort Riley Post, 20 January 1961, 12; “2500 Citizen-Soldiers Begin Training in June," The Fort Riley Post, 29 March 1963, 1.

355 “Army Idea Makes Progress," The Fort Riley Post, 17 February 1961, 6.

356 "Strength Buildup Head the List of 1961 Military News Events," 1.
} 
pated in "Exercise Big Blast XIV," a 2,500 troop exercise conducted at Fort Sheridan, IL. ${ }^{357}$ This was the last of a series of exercises that had been held twice a year since 1954, alternating between Fort Riley and Fort Sheridan. ${ }^{358}$ The men from Fort Riley played the part of a mechanized rifle division for the 16th Aggressor Army maneuvering against their own 5th Army comrades. 359 That November, five battle groups of the 1st ID trained in Pike National Forest near Colorado Springs, CO, for six weeks with 1,300 men and equipment. 360

Armor and Cavalry divisions of the 1st ID were first sent to Fort Irwin, CA for training in the fall of 1961, due to space limitations at Fort Riley for combat readiness training. ${ }^{361}$ Starting in February and March 1962, Operation Bristle Cone moved approximately 3,000 troops to Fort Irwin, CA for training in desert techniques and started joint tactical exercises with air operations. ${ }^{362}$ That summer, exercise "Swift Strike II" in North and South Carolina, took troops from almost every unit at Fort Riley for the 70,000 troop training exercise. ${ }^{363}$ Training also took place in Pike National Forest in Colorado and at Fort Sill in Oklahoma. ${ }^{364}$ Additional exercises were held at Fort Riley in the fall of 1962. ${ }^{365}$ Later exercises took place in Florida, California, Nevada, and Arizona. 366

Overseas training exercises were also a large part of the movement of troops from Fort Riley in 1962 and 1963, primarily troop rotations through Germany, including Berlin, and the Korean De-Militarized Zone (DMZ). A number of these exercises were not only "training", but "real world" exercises as well. During the rotation of the 1st ID, 12th Infantry, and 2nd Battle Group to Germany for the J uly 1962 training exercise "Long Thrust IV," the troops were moved to Berlin by the overland road route through East

\footnotetext{
357 “Exercise ‘Big Blast XIV' Starts Today At Fort Sheridan,” The Fort Riley Post, 27 January 1961, 1.

358 "Fort Riley Personnel To Take Part in Exercise "Big Blast XIV” Jan. 27-29," The Fort Riley Post, 20 January 1961, 1.

359 “Exercise ‘Big Blast XIV' Starts Today At Fort Sheridan,” 1.

360 "First Division Units Training at Pike National Forest," The Fort Riley Post, 9 November 1961, 12.

361 “Pictorial Review of 1961 at Fort Riley," The Fort Riley Post, 5 January 1962, 8.

362 Later, the Air Force and Army held joint training, but this reference did not indicate this.

363 “Maneuvers Begin In The Carolinas," The Fort Riley Post, 10 August 1962, 1.

364 “Have Division Will Travel," The Fort Riley Post, 17 August 1962, 16.

365 “Two On-Post Exercises Slated for This Fall: Will Be Held in Late October, mid-November," The Fort Riley Post, 7 September 1962, 1.

366 "Exercise to Include 12 Riley Units," The Fort Riley Post, 20 March 1964, 1; "Brigade Strength Army Begins Florida Exercises," The Fort Riley Post, 4 September 1964, 1, 2.
} 
Germany and the troop movement was delayed at checkpoints on the autobahn by Soviet troops. ${ }^{367}$ There were 1,400 troops from Fort Riley airlifted to Germany for exercise "Long Thrust V" in September and October 1962. 368 This exercise continued through "Long Thrust VIII" when the 8th Infantry and associated units went to Germany in J uly 1963 for a sixmonth rotation. ${ }^{369}$ The object of these exercises was partially to practice quick movement of troops and equipment. Overseas troop movements involved just the combat-ready troops without the heavy equipment, but 1,400-3500 troops could be airlifted overseas in a 24- 48 hour period. ${ }^{370}$ In securing their own preparedness for a newly mobile and combat ready Army, the 1st ID became very proficient at mobilization around the world.

This troop rotation was many times conducted through non-5th Army command, which involved the switching of unit names and colors. This constant rotation and training ultimately led to the "Big Red One" being once again composed of the "original" units from when the 1st ID was formed in 1917 during World War I as the "1st American Expeditionary Force." 371 This was also part of the ROAD program of reorganization of Army units. ${ }^{372}$

The combat-ready stance relied heavily on air transport to move troops and cargo to flashpoints in a sort amount of time. As a result, some of the equipment purchases went for aircraft. The 1st ID received a number of both fixed wing aircraft and helicopters with the Army National Guard assuming a larger share of the air defense role with Caribou and Mohawk airplanes, and Choctow, Iroquois, and Chinook helicopters. ${ }^{373}$ At Fort Riley, the first H-34 Choctow helicopters were received in September 1961 at Marshall Field. ${ }^{374}$ In October 1962, Fort Riley received a two-engine H37B Mojave helicopter flown by Fort Riley pilots from the Sikorsky Helicopter Corporation factory in Stratford, CT. This helicopter was one of the largest and most powerful helicopters of its day with a capability of carry-

\footnotetext{
367 "12th in Berlin, 13 ${ }^{\text {th }}$ to Germany," The Fort Riley Post, 28 September 1962, 1.

368 "13th Infantry Airlifted to Germany Monday," The Fort Riley Post, 5 October 1962, 1.

369 “'Longthrust VII' Completed; 13 $3^{\text {th }}$ Back Home," The Fort Riley Post, 12 April 1963, 1, 2; “Eagles' Prepare for 'Long Thrust'," The Fort Riley Post, 12 July 1963, 1.

370 “13 $13^{\text {th }}$ Infantry Airlifted to Germany Monday," 1.

371 “Original Units Rejoin 'Fighting First'," The Fort Riley Post, 4 October 1963, 1, 2.

372 "26th Infantry Becomes Part of 1st Division," The Fort Riley Post, 8 February 1963, 1.

373 “Army Stresses New Weapons Concept in 60," 13; “Army Idea Makes Progress," 6.

374 “Post Receives First H-34 Helicopters," The Fort Riley Post, 29 September 1961, 3.
} 
ing 36 combat ready troops or a cargo capacity of 7,000 pounds. ${ }^{375}$ It was assigned to the 47th Helicopter Company, a medium-sized company of 140 enlisted men and thirty-eight officers newly activated in May 1962. Ultimately, Fort Riley and the 47th Helicopter Company received 16 of the 90 helicopters authorized for the Army in 1962. ${ }^{376}$ Then in April 1964, the 1st Aviation Battalion, Company A received four UH-1B Iroquois helicopters. ${ }^{377}$ In J uly 1964, the 4th Cavalry was assigned Troop D (Air) with its compliment of nine $\mathrm{OH}-23 \mathrm{G}$ and seventeen UH-1B Huey helicopters. ${ }^{378}$

\subsubsection{Fort Riley construction in the early 1960s}

Fort Riley grew during the 1961- 1963 with a combination of new buildings and refurbished older facilities. As the 1st ID shifted to a combat-ready division, the numbers of enlisted recruits diminished, and an increase was seen in the number of older, married soldiers. This necessitated a corresponding shift in construction, with a large number of family quarters constructed during this period, and a complete lack of new large-scale barracks projects. There were three large housing projects, all on the Custer Hill, the new divisional area being constructed for the 1st ID.

At the beginning of 1962, Fort Riley base had a population of 27,026 consisting of 19,398 enlisted men, 1,528 officers, and 1,474 Department of Army civilians. There were housing shortages on and off base as the population grew with the increased strength needed for combat ready units. ${ }^{379}$ The J unction City- Fort Riley schools also started a major construction program with new elementary and junior high schools on Custer Hill. ${ }^{380}$

Groundbreaking for the first new housing project was begun in April, 1961 under the Capehart housing initiative. Similar to the earlier Wherry legislations, Capehart housing utilized private firms for construction capital, with the soldier inhabitants receiving stipends to use for rent to repay the builders. The construction of the 867 family units took place in three phases over twenty-four months. ${ }^{381}$ The project was built by the construc-

\footnotetext{
375 “Riley to Get New Mojave Helicopter," The Fort Riley Post, 5 October 1962, 1.

376 "First Mojave Helicopter Arrives," The Fort Riley Post, 19 October 1962, 11.

377 “Fort Riley Aviation Unit Gets New Iroquois Helicopters," The Fort Riley Post, 10 April 1964, 10.

378 "4th Cavalry Gets Helicopter Unit," The Fort Riley Post, 2 July 1964, 5.

379 “Kansas's Sixth Largest city Altered By Crisis,” The Fort Riley Post, 9 February 1962, 1.

380 lbid.

381 "Ground Breaking Marks Start of Housing Project in Custer Hill Area," The Fort Riley Post, 7 April 1961, 1.
} 
tion firms of Robert McKee Construction Company of El Paso, TX, Emery Construction Company of Topeka, KS, and Bennett Construction Company of Group of Manhattan, KS for the cost of $\$ 13,621,980 .{ }^{382}$ Nearly all the units were duplexes, although a handful of four- and six-family apartment buildings were included. The three phases resulted in three housing areas at Custer Hill: Monteith Heights officer housing, Peterson Heights NCO housing, and Warner Heights NCO housing (Figure 35, Figure 36, and Figure 37). Monteith Heights opened first in May 1962; the others opened in 1963. 383

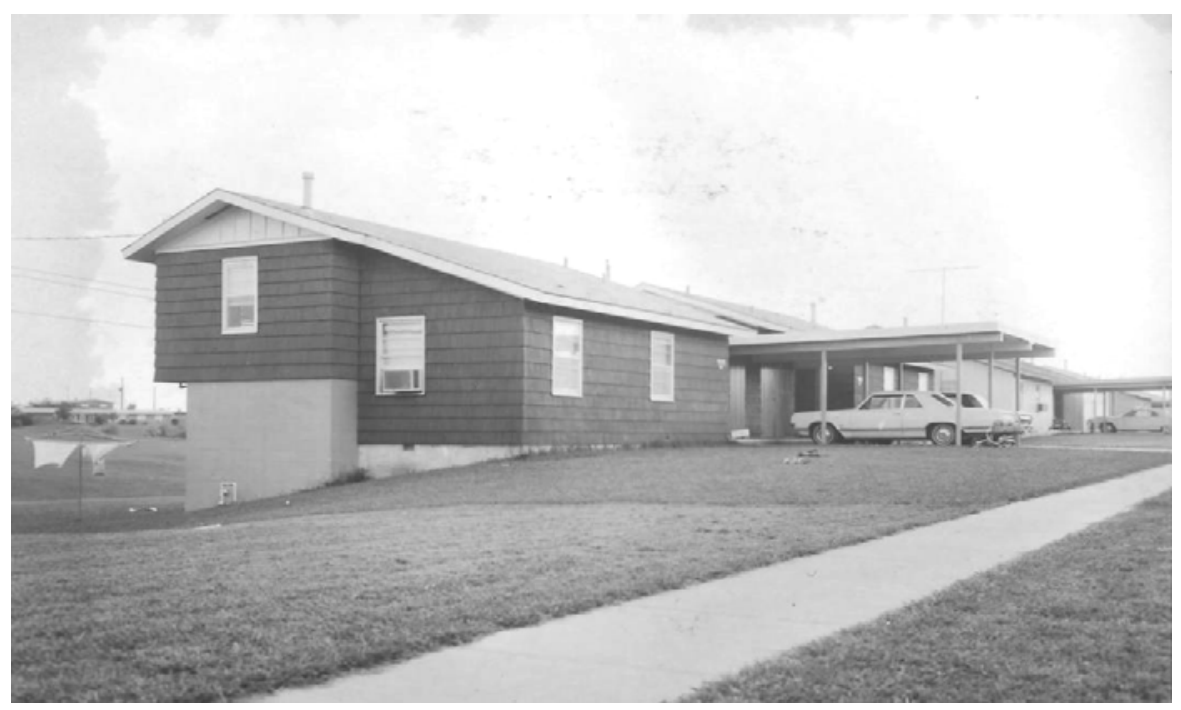

Figure 35. Monteith Heights housing, 1966 (NARA).

Besides housing, little other construction occurred during this time. Some buildings were rehabilitated or converted to other uses, particularly the remaining World War II station hospital facilities at Camp Whitside. At the beginning of 1961, Fort Riley opened its new Reception Station from converted buildings in this area. Its location in the hospital allowed for a 24-hour mess along with 24-hour personnel processing accommodating any travel schedule. 384

\footnotetext{
382 Ibid.

383 “Kansas's Sixth Largest City Altered By Crisis," 1. In April 1963, housing areas at Fort Riley were named for 1st ID Medal of Honor winners who died in combat: Sergeant Colyer, Sergeant Peterson, 1st Lieutenant Monteith, and Corporal Warner ("Areas Are Named for Men of 1st," The Fort Riley Post, 5 April 1963, 1.).

384 “First Receptees Arrive At Fort Riley's New Reception Station For Processing," The Fort Riley Post, 6 January 1961, 1.
} 


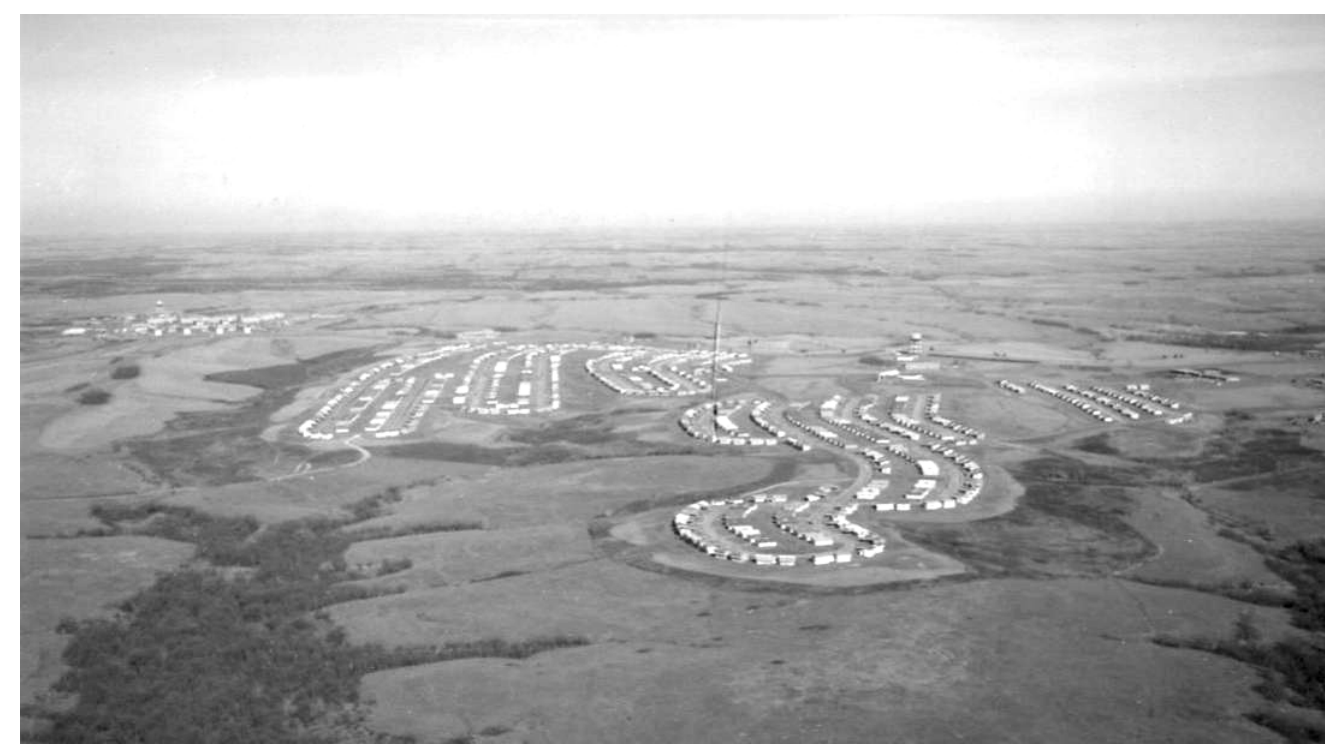

Figure 36. Warner Heights (left), Peterson Heights (center), and Monteith Heights (right), Custer Hill, 1966 (NARA).

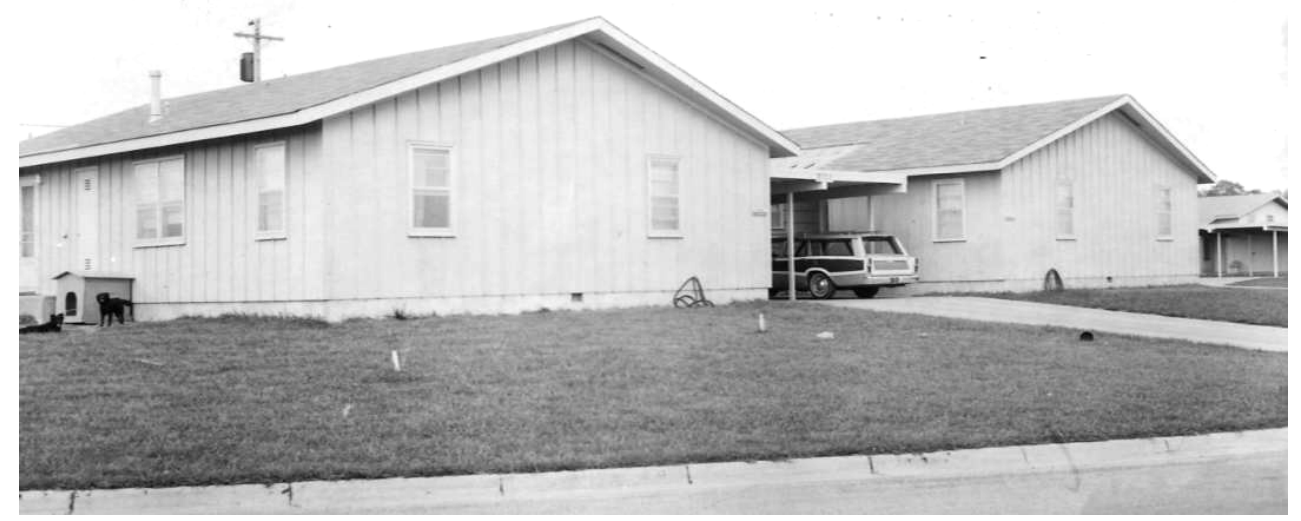

Figure 37. Warner Heights housing, 1966 (NARA).

On J une 14 of that year, the Cavalry Memorial was dedicated on the Cavalry Parade Ground amid the larger fanfare of the 1st ID's Organization Day with the entire division passing in review of the new statue-foot, mounted, armored, and aircraft-with over 9,000 people in attendance. 385 This memorial was a life-size statue of a horse and rider from the 1890s inspired by Frederick Remington's drawing, "Old Bill." 386 It took two sol-

\footnotetext{
385 “Cavalry Memorial Dedication Highlight Organization Day,” The Fort Riley Post, 16 June 1961, 1.

386 The Fort Riley Post reported the Frederick Remington painting as both "The Cavalryman" and "Old Trooper" in separate articles, but looking at Remington's drawing titled, "Old Bill", it is an obvious match. The statue itself is referred to as either "Old Bill" or "Old Trooper" in subsequent references.
} 
diers from Chicago, Specialist Four Robert Greene and Private First Class Richard C. Donda, over a year to sculpt the form. The statue, standing 18.5' high, was expected to last 100 years at the time of its dedication. The cost of the statue was covered by the J unction City Chamber of Commerce. 387

On base, 1962 started out with the closing of the one-lane Engineer Bridge due to one pier being destroyed and another damaged from an ice floe buildup on the Kansas River. This caused the trip between Marshall Field and other parts of the post to be considerably longer since traffic had to be routed through J unction City. ${ }^{388}$ Repairs were completed and traffic resumed by March. ${ }^{389}$ This bridge had previously been dealt a harsh blow in the 1951 flood, and it was decided to construct a new, higher bridge over the Kansas River in its place. Construction of a "replacement" bridge was started in November 1962 and completed in April 1964, connecting the Main Post to Marshall Field and Interstate 70. Although the one-lane Engineer Bridge remained open and active after the opening of the new bridge "until no longer practical," the new bridge allowed traffic to flow faster and easier. 390 The Army Corps of Engineers built the new bridge to higher specifications, especially the piers, at a cost of approximately $\$ 8$ million. Construction was done by Armstrong Inc. of Ames, Iowa and List and Clark Construction Co. of Kansas City, MO. 391 When the new 960' bridge was opened across the Kansas River on 1 May 1964, it was dedicated to a World War II Congressional Medal of Honor recipient as the Private Robert T. Henry Bridge. 392

Then in J uly 1962, the one-lane bridge over Three Mile Creek on state highway K-18 was reopened after being closed. The bridge was rededicated at its opening as "North Dakota Bridge" in honor of North Dakota's $164^{\text {th }}$ Engineer Battalion, a National Guard unit on active duty at Fort Riley, spotlighting the value of the National Guard and Reservists during this time period. 393

\footnotetext{
387 "Soldier Talent Provides Tribute to the Cavalry," The Fort Riley Post, 16 June 1961, 1.

388 “Bird's-Eye View of 1962," The Fort Riley Post, 28 December 1962, 12.

389 lbid, 13.

390 "Bridge Construction in Full Swing," The Fort Riley Post, 19 April 1963, 11.

391 Ibid. 11.

392 “Bridge Dedicated as Memorial To Soldier," The Port Riley Post, 1 May1964, 1.

393 “Bird's-Eye View of 1962,"15.
} 
In April 1963, a six-month renovation of the control tower at Marshall Field was completed. The $\$ 25,000$ renovation provided a new five-story building with state-of-the-art equipment including a new weather facility. The airfield was operating at less-than-full capacity because of the lack of a control tower during the renovation.

The recreation opportunities afforded troops in the early 1960s had expanded by the additions of a new NCO club, bowling alleys, a driving range, and several lakes. The Custer Hill Non-Commissioned Officers' Open Mess opened on 23 December 1963 after a year and a half of construction on the 27,500 square-foot building. ${ }^{394}$ The project announced a call for bids on 11 May 1962. Plans and specifications were held by the Post Engineer, and called for a one-story brick structure. Bids were received and opened on 10 August 1962. ${ }^{395}$ The new NCO club included a ballroom large enough for 200, a cocktail lounge, a modern kitchen and dining room, a barbershop, and a nursery. Several features were noted at its opening, such as the presence of three color televisions, acoustical tile ceilings throughout the building, and the "oriental motif" of the entrance. 396

A new driving range at the Custer Hill Golf Course opened on September 13, 1963. 397 On October 25, 1963, the new bowling alleys in Magrath Field House at Camp Funston opened. The facility provided eight lanes with fully automated pin spotters and ball return. ${ }^{398}$

Outdoor activities were not neglected, with a series of lakes opened for fishing and other types of recreation. Camp Moon Park and Lake was completed in 1960 with a nine-acre lake and picnic facilities west of the O'Donnell Heights housing area. Due to the size of the lake, boating was limited, but the lake was stocked and opened to fishing. It was one of six areas on the Post available for picnicking. ${ }^{399}$ Another stocked lake, Breakneck Lake, was the largest lake entirely within the boundaries of Fort Riley at three acres. The larger ten-acre Packers Hill Lake was in the planning stages in the spring of 1962, with the construction of four ten-acre lakes

\footnotetext{
394 “\$600,000 NCO Club To Open Monday Noon,” The Fort Riley Post, 20 December 1963, 16; “Seek

Bids For New NCO Club On Custer Hill," The Fort Riley Post, 27 July 1962, 1.

395 “Non Coms Plan New Open Mess On Custer Hill," The Fort Riley Post, 11 May 1962, 5.

396 “New NCO Club, Luxurious Spaciousness Featured," The Fort Riley Post, 3 January 1964, 6.

397 "Golf Pro, Reduced Rates Highlight Opening of Driving Range Tonight," The Fort Riley Post, 13 Sep-

tember 1963, 1.

398 “General's Strike Opens Funston Bowling Lanes," The Fort Riley Post, 1 November 1963, 19.

399 “Camp Moon Area at Fort Riley is Popular for Family Picnics," The Fort Riley Post, 30 June 1961, 1.
} 
planned by 1965. This was part of a five-year program to expand fish and game facilities on post. 400

By 1965, Fort Riley could offer recreation through tennis courts at Camp Funston, Custer Hill, Main Post and Camp Forsyth. Each of these locations also offered outdoor swimming pools, with two on the Main Post - one for officers and one for enlisted men. Each location also provided an airconditioned theater equipped to show Cinemascope movies. ${ }^{401}$

Beginning in the late 1950s, it became apparent that the Fort Riley reservation was not large enough for the proper training of an infantry division. Additional land was needed for maneuvering equipment and for firing tank weapons. Therefore, in 1965 Fort Riley acquired 46,065 acres of land around the west, northwest, and north perimeters of the existing 51,902 acre reserve. Fort Riley also gained permission to use 3,435 acres of land on the Milford Reservation for field exercises, cross country maneuvers, and gunnery practice.

400 “New Lake Attracts Post Fishermen," The Fort Riley Post, 7 July 1961, 11; “New Fishing Lake Planned Here," The Fort Riley Post, 27 April 1962, 1.

401 “Welcome to Fort Riley," circa 1965. Vertical file: “228.03 HRC 331 Posts - Riley, Fort,” Center for Military History, Washington, D.C. 


\section{Architectural Overview of Significant Buildings Constructed 1953-1960}

This architectural overview examines several Fort Riley buildings constructed during 1953- 1960; the categories are based on architectural and functional similarities. ${ }^{402}$ In most but not all cases, a military definitive design (i.e., standard plan) was used to construct buildings within a given category. The use of standard plans was (and still is) common practice in military construction. Standardization is common because it ensures architectural equity from installation to installation, facilitates funding requests to Congress, and expedites construction once approvals and funding have been obtained. Standardization is applied both to very large projects (e.g., hospital facilities) and small support infrastructure (e.g., utilities buildings).

Due to specific Fort Riley requirements, however, it sometimes was beneficial to deviate from standard plans for highly specialized project needs (e.g., Building 502, an MP information booth). Accordingly, the result was a purpose-built facility. Similarly, some construction projects were small or inexpensive enough to make the use of military standard plans unnecessary. In such cases, a building was erected of local design and constructed of local or readily available materials (e.g., Building 745, a generator house).

The primary building types that represent the important Fort Riley themes identified in this report fall into three major categories: (1) airfield infrastructure, (2) medical facilities, and (3) motor pool buildings associated with the first group of facilities at Custer Hill. While all of these buildings possess significance, only select Marshall Field facilities are recommended eligible to the NRHP. The remaining buildings from these three categories are ineligible due to their lack of integrity. The character-defining features of the eligible building types are listed below in Table 1.

\footnotetext{
402 As part of this effort to compile three separate reports, formatting discrepancies resulted in architectural discussion of the eligible pre-1945 buildings occurring in the context chapter. In Fort Riley Building Inventory and Evaluation, 1946-1952 and 1961-1963, no buildings were found to be eligible. The 2007 report, Fort Riley Early Cold War Building Inventory and Evaluation, 1953-1960, determined three buildings to be eligible to the NRHP. These three are discussed in this chapter.
} 
In addition to this architectural overview of significant building types, data specific to all Fort Riley buildings covered by this study are detailed in the individual building survey forms provided to Fort Riley personnel.

Table 1. Character-defining features of recommended eligible Marshall Field buildings.

\begin{tabular}{|l|l|l|}
\hline Building type & Building Number & Character-defining features \\
\hline Maintenance hangar & 723 & $\begin{array}{l}\text { Proximity to airfield tarmac } \\
\text { Central long-span steel-framed aircraft bay topped } \\
\text { with gable roof } \\
\text { Flanking two-story flat-roofed, CMU office modules } \\
\text { Stacking oversized multi-panel aircraft doors with } \\
\text { smaller pilot doors } \\
\text { Projecting hangar door pockets at front sidewalls }\end{array}$ \\
\hline Operations building & 725 & $\begin{array}{l}\text { Proximity to airfield } \\
\text { Two-story structure with simple rectangular plan \& } \\
\text { slightly-pitched roof } \\
\text { Separate entries for operations officer \& enlisted } \\
\text { personnel } \\
\text { Distinctive external staircase to 2 } \\
\text { over operations officer entry }\end{array}$ \\
\hline $\begin{array}{l}\text { Flight simulator } \\
\text { building }\end{array}$ & 720 & $\begin{array}{l}\text { Proximity to airfield } \\
\text { One-story structure with wide rectangular plan \& } \\
\text { slightly-pitched roof } \\
\text { Distinctive simulator turbo-compressor housings } \\
\text { with removable covers } \\
\text { Shop \& parts storage room window secured with } \\
\text { grating }\end{array}$ \\
\hline
\end{tabular}

\subsection{Marshall Army Air Field infrastructure}

\subsubsection{Aircraft hangar: Building $\mathbf{7 2 3}$}

The late 1950s hangars at Marshall Army Air Field were part of a construction program launched by the Army to support their new air cavalry concept and the AAUTC. This program was dominated by two standard hangar designs: Plan No. 39-01-62, entitled 12,000 Square Feet- 20,000 Square Feet with Shops, and Plan No. 39-01-64 for 20,000 Square Feet- 
35,000 Square Feet with Shops. Both plans are essentially identical, with variation only in scale. 403

The smaller configuration (Figure 38) featured a central gable-roofed aircraft hangar bay flanked on each side by two-story office modules. The high hangar bay was framed in structural steel and spanned by large Howe trusses, while the office modules were of concrete masonry unit (CMU) construction. Six metal telescoping aircraft doors were typical at each end of the hangar. Hangar door pockets projected from the front and back sidewalls and contained the stacked hangar doors when drawn. Two pilot doors for personnel use pierced the telescoping aircraft doors. In addition, special systems for fire protection and fluid drainage were included. A 7' draft curtain, in the form of a metal partition attached at the ceiling, prevented the spread of fire. This draft curtain ran longitudinally down the centerline of the hangar bay. Three evenly-spaced outlet pits were cut into the hangar bay floor to drain off aircraft maintenance fluids.

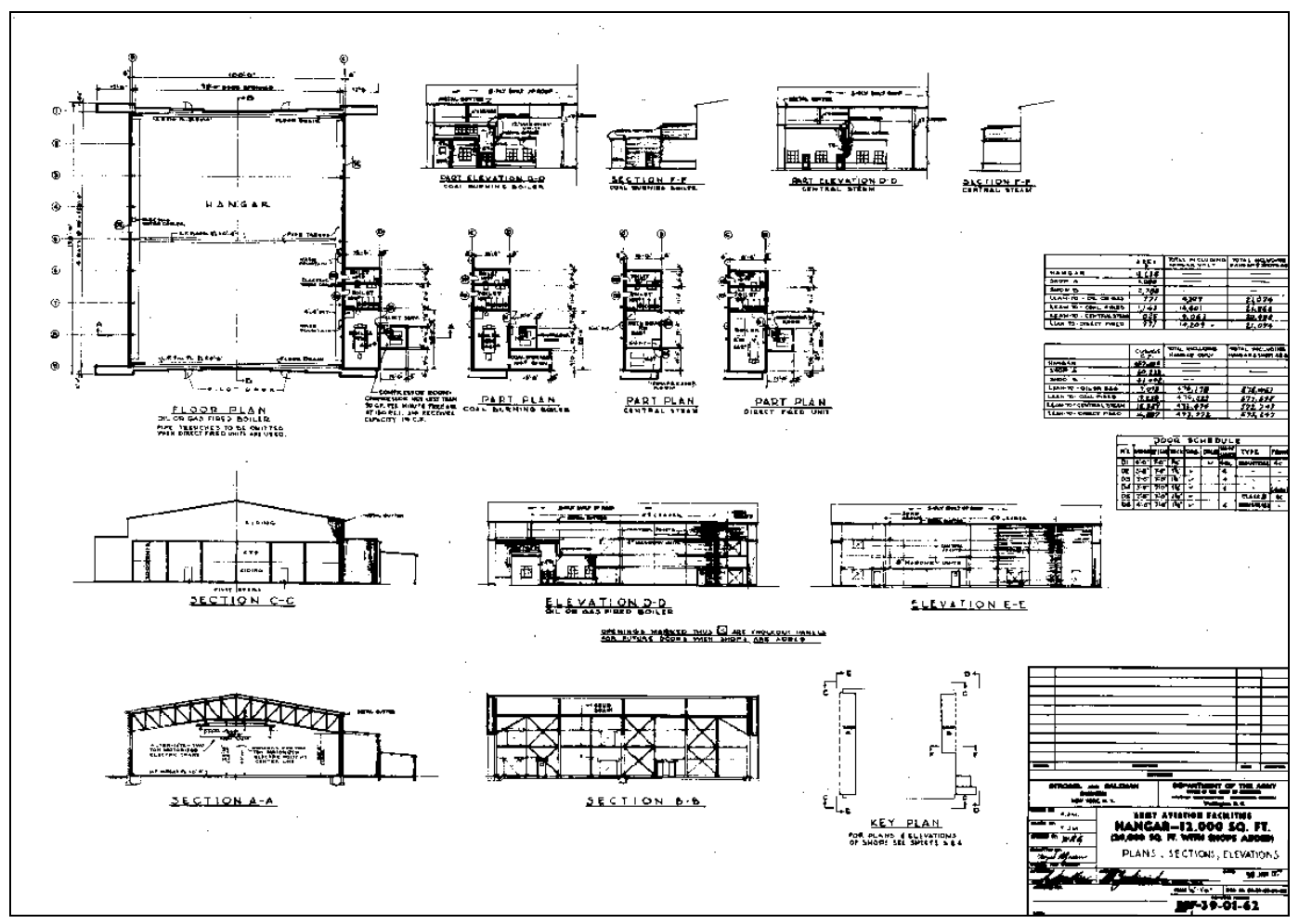

Figure 38. Definitive design for the smaller Army Air Cavalry hangar (ERDC-CERL 1999).

403 Pedrotty, et al., Historical and Architectural Overview of Military Aircraft Hangars, 6-18. While these plans were developed in the late 1950s, examples of their use can still be found in the late 1980s; Building 727 is an example of the larger air cavalry facility; it is not eligible to NRHP, however, due to integrity issues. 
Fort Riley Building 723 is representative of the smaller hangar type (Figure 39). According to property category codes, Building 723 originally provided space for the maintenance and repair of Army aircraft at all levels, but is now used as storage. ${ }^{404}$ Although roofing material has been replaced, the hangar doors covered in sheet metal, and window airconditioning units were added, these exterior alterations are either reversible or not obvious to the casual observer.

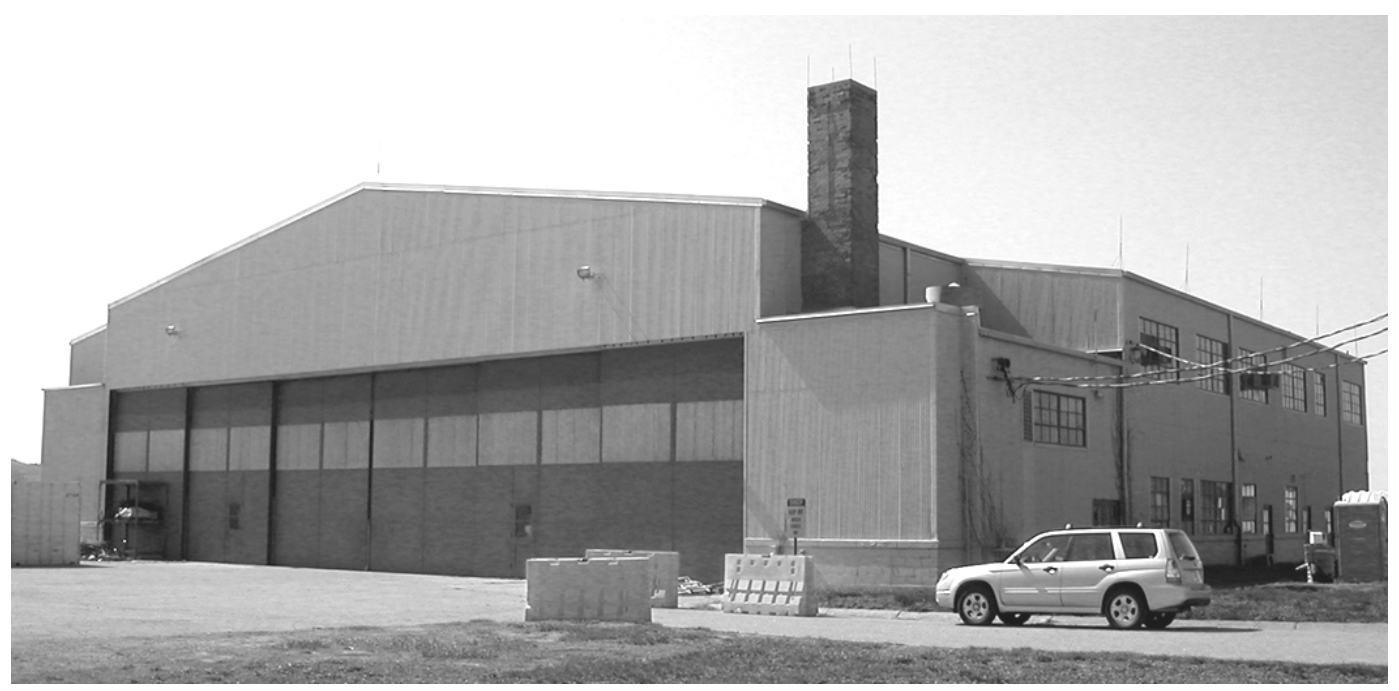

Figure 39. Fort Riley aircraft hanger: Building 723 (ERDC-CERL 2007).

\subsubsection{Operations building: Building 725}

The Marshall Army Air Field operations building, Building 725, is documented in Drawing No. 30-07-01, Operations Building, dated 15 December 1959 and located in the Fort Riley drawing vault. Wilson \& Company, Architects-Engineers of Salina, Kansas, modified the U.S. Army Corps of Engineers- Kansas City District's standard plan to meet local conditions and produced the working drawings. This facility, located at an airfield, is used by aviation units for administration and training functions. 405

Building 725 is two stories of CMU construction finished with facing brick. The roof is supported by slightly-pitched Warren trusses. Simple concrete sills run below the single and paired double-hung window units. General first-floor access was through double doors on the south elevation, and officer access was through a single door on the west end. The first floor

\footnotetext{
404 Department of the Army, Pamphlet DA-PAM 415-28: Guide to Army Real Property Category Codes, (Washington, D.C.: Headquarters, Department of the Army, 2006), 51. DA Form 2877, Real Property Record. Fort Riley, Kansas: Department of Public Works, n.d.

405 DA-PAM 415-28, 25.
} 
housed space for a general office and dispatch area, parachute issue room, flight operations, platoon commanders, and the operations officer. Toilet facilities for both officers and enlisted personnel and mechanical equipment spaces were located at the east end of the floor.

Exterior access to the second floor was via external stairs at the west end of the building. Beneath this staircase was enclosed storage for the aviation unit. Interior access was provided by an internal stairwell from the first floor (additional storage space was located on the first floor under this stairwell). The second floor housed space for personnel staff, pilot locker room and toilets, an alert room, the commanding officer, and a large briefing room that consumed half of the floor at the west end. The briefing room had room for approximately 20 tables, a raised speaking platform, and wall-mounted screen charts and chalkboards.

Fort Riley Building 725 retains its original use (Figure 40). Although exterior doors have been replaced, and vents and obscure glass had been installed in window openings, these exterior alterations are considered reversible.

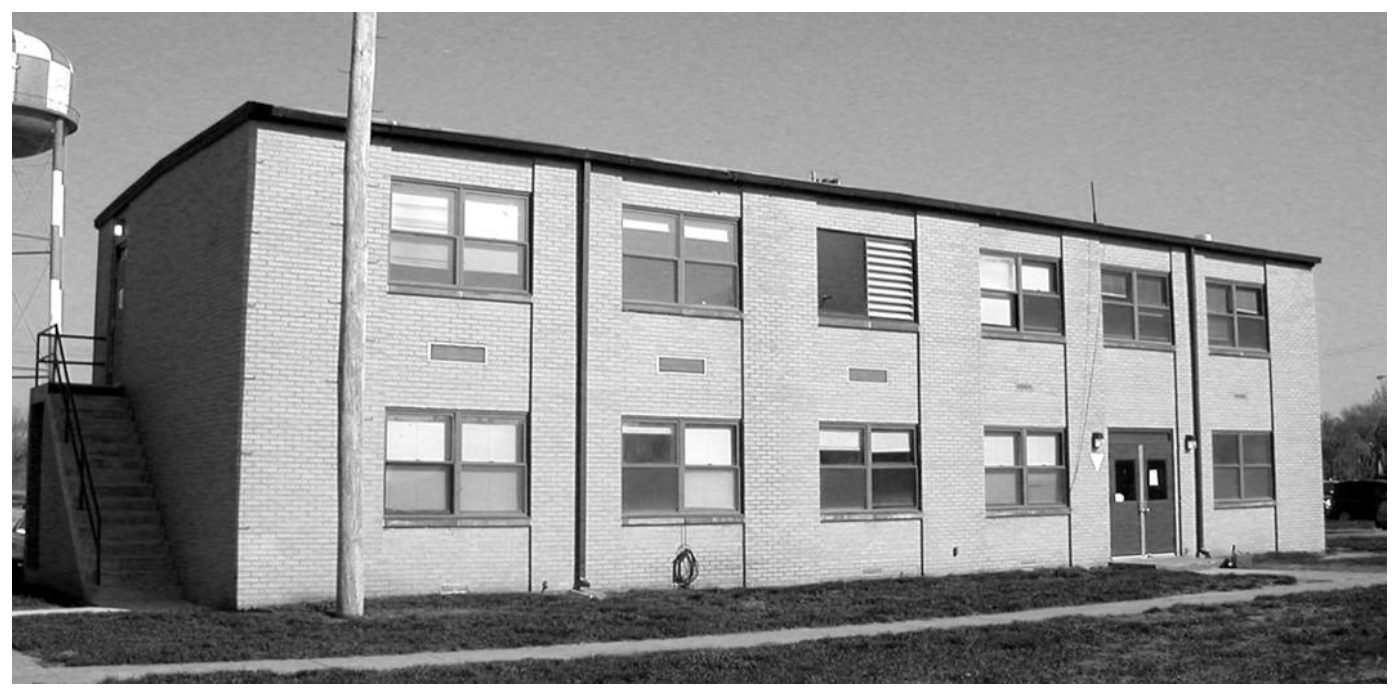

Figure 40. Fort Riley Building 725 (ERDC-CERL 2007).

\subsubsection{Flight simulator building: Building $\mathbf{7 2 0}$}

The Marshall Army Air Field flight simulator building, Building 720, is documented in Drawing No. 28-13-01, Flight Simulator \& Utilities, dated May 1959 and located in the Fort Riley drawing vault. Like Building 725, Wilson \& Company, Architects-Engineers of Salina, Kansas, modified the U.S. Army Corps of Engineers- Kansas City District's standard plan so that 
Building 720 would meet local conditions and thus, produced the working drawings. This facility was used originally by aviation units for instructional and training purposes using simulation.

Building 720 is one story in height and of CMU construction. The CMU walls are faced in brick. The slightly pitched roof is supported by lightweight steel joints supported mid-span by an interior CMU load-bearing wall. Simple concrete sills run below the single vent openings and paired double-hung windows. Primary first-floor access was through double doors on the south elevation. Simulator room access was through double doors on the north elevation. Double doors on the west side of the building provided access to the mechanical equipment room.

The interior originally was dominated by the north-end simulator room, which housed six flight simulators. Cable connecting pits were located at each simulation station and cable trenches in the floor housed conduit that joined the simulators to the centrally-located Air Traffic Control (ATC) console. Turbo-compressor housings for the flight simulators flanked both sides of the simulator room exterior. The remainder of the building interior housed office, classroom, toilet, janitor closet, and mechanical equipment spaces. In addition, a shop and parts storage room was located for dual access from the central hall and simulator room. The windows of this space remain protected with security grating.

In 1989, Fort Riley Building 720 (Figure 41) was converted to a clinic without beds. It currently is a company headquarters building (also known as a company operations facility) for daily administrative and supply activities at the company, battery, and troop levels. ${ }^{406}$ Although it has undergone multiple conversions, the only exterior modification of note is the replacement of doors on the north elevation, which is considered reversible.

406 Department of the Army, Pamphlet 415-28: Guide to Army Real Property Category Codes, 29. 


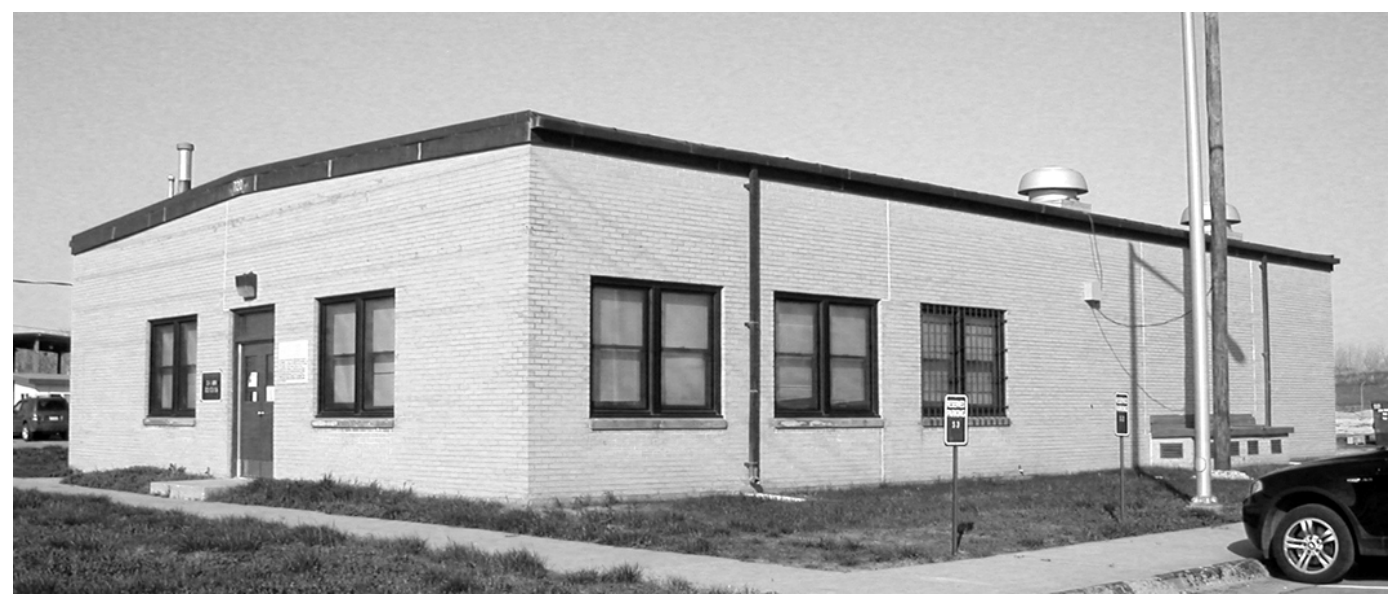

Figure 41. Fort Riley Building 720, south and east elevations (ERDC-CERL 2007). 


\section{Determinations of Eligibility to the National Register}

This report compiles three surveys done by ERDC-CERL teams of Fort Riley buildings constructed by the U.S. Army from 1855- 1963. The list of all buildings and structures surveyed, along with their determinations of eligibility, can be found in Appendix B.

Once Fort Riley's historic context was completed, the historical trends evident in that context were determined. The individual buildings and structures were then evaluated against those trends to see if the properties were significant in representing any of those trends. The significant buildings and structures were then analyzed for retention of integrity (see Appendix A for significance criteria and aspects of integrity). Buildings with both significance and integrity were determined eligible for the NRHP. Again, the construction dates of the 309 buildings ranged from 1855- 1963.

\subsection{Identification of significance}

The identification of historically significant properties can be achieved only through evaluation of their position within the larger historic context. According to the NRHP, historic contexts are defined as "...the patterns, themes, or trends in history by which a specific occurrence, property, or site is understood and its meaning (and ultimately its significance) within prehistory or history is made clear." 407 A historic property is determined to be either significant or not significant based on the application of standardized National Register Criteria within the property's historical context. Those criteria and their relation to Fort Riley are described in detail on the following pages.

\footnotetext{
407 U.S. Department of the Interior, National Park Service, National Register Bulletin: How to Apply the National Register Criteria for Evaluation, Bulletin 15 (Washington, DC.: GPO, 1997), 7. Available at http://www.nps.gov/nr/publications/bulletins/nrb15/ (accessed September 2009).
} 


\subsubsection{Criterion A: Event}

The property is associated with events that have made a significant contribution to the broad patterns of our history.

Creation of the historic context revealed nine areas of significance at Fort Riley that were associated with events or patterns in history, which were organized into the following thematic groups:

\subsubsection{Original Post Thematic Group (1850s)}

This thematic group is made up of the few remaining permanent buildings erected at Fort Riley during its initial construction period which took place in the 1850s. Originally Fort Riley was an early frontier outpost that offered protection to traders and settlers traveling along the Santa Fe, Oregon, and Smoky Hill Trails. As such, it provided a definitive step in the settlement and development of the Kansas territory.

\subsubsection{Cavalry and Artillery Thematic Group (1886-1916)}

This thematic group is made up of the permanent buildings associated with the establishment of the Cavalry and Light Artillery School. It is a cohesive architectural environment based on Captain George Pond's 1887 plan for the post. The establishment of this school marked the beginning of Fort Riley's recognition as an important center of advanced military training.

\subsubsection{1927-1940 Thematic Group (1927-1940)}

This group is made up of permanent buildings constructed at Fort Riley during the major nationwide Army building program that began in 1927. In some cases, funds were used from government work programs created during the Great Depression. These buildings contribute to an understanding of the twentieth century historical development of the installation. Most of the housing units included in this group are situated in areas visually separated from Pond's 1887 plan and feature Colonial Revival style details. They were usually built around open courts or facing open greens, exemplifying the type of planning that was popular at the time.

Garages are listed as part of this thematic group because of their association with nearby housing. Although these structures make little significant contribution to their group, they are constructed of appropriate building materials and are a functional aspect of their associated structure. 


\subsubsection{WPA Camp Thematic Group}

This group is made up of four buildings that are associated with the old Works Progress Administration (WPA) Camp. The camp was located at Fort Riley from 1935- 1942 and housed men participating in the WPA work program. Besides relieving the Kansas unemployment situation, it provided Fort Riley with a much-needed labor pool during an expansion period.

\subsubsection{World War II Build-Up Thematic Group}

This group is made up of significant permanent buildings associated with the installation's build-up just prior to World War II. These buildings contribute to an understanding of the twentieth century historical development of the installation.

\subsubsection{Combat Training and Army Schools (1946-1963)}

Fort Riley's mission of training soldiers shifted direction after World War II, with the elimination of the horse cavalry. The $10^{\text {th }}$ ID had begun providing combat replacement training at Fort Riley in 1948. Realism in training was provided by a specialized unit, the Aggressor Cadre, which was formed that same year to serve as the maneuver enemy for the United States Army. With the eruption of the Korean War, a large troop buildup in the Army was necessary and the training load at Fort Riley increased greatly. Basic training was provided for soldiers on a replacement basis for casualties in Korea, and returning troops were provided with more specialized training. Near the very end of the conflict, Fort Riley was selected as the home of a new Fifth Army Reception Station for new recruits, located at Camp Forsyth. After the Korean War, the mission of troop training continued at Fort Riley and was taken over by the 1st ID in 1955. The training at Camp Funston was for combat infantry replacements, to keep established units up to strength; most replacements went to Europe or the Far East. Training for these soldiers consisted of two similar programs developed by Army Field Forces; one focused on light weapons, and the other on heavy weapons. In addition to providing basic and specialist training, Fort Riley was home to the Army General School. Founded in 1946 as the Ground General School, it succeeded the famed Cavalry School at Fort Riley, providing the post with an unbroken string of service schools stretching back to the late $19^{\text {th }}$ century. The mission of the Ground General School (re-designated as the Army General School in 1950) was to provide 
training to officers and men as S2 and G2 personnel, up to division level and to train certain types of intelligence specialists.

Building 9389, a range observation tower constructed in 1951, is representative of the skills needed to turn raw recruits into combat soldiers and is an integral part of range facilities. Building 9389 meets NRHP evaluation criterion A for its significance in illustrating the Fort Riley Combat Training and Army Schools theme.

\subsubsection{Army Aviation, Fixed and Rotary-Wing Training (1953-1960)}

During the early Cold War period, the Army increased its aviation capabilities by improving the helicopter and using it as a means to move cargo and troops across battlefields. The shake out of responsibilities between the Army and the newly created Air Force in the late 1940s resulted in an Army mission with an increased focus on rotary-wing aircraft. The Army's use of helicopters during the 1950s grew to include reconnaissance, medical evacuation, and fire support.

A continuous mission of aviation training exists at Marshall Army Air Field from the early 1920 s to the present. After the Korean War, rotarywing aircraft were assigned to the airfield, and training was altered to include this type of aircraft. In late 1953, Marshall Field received the first three Sikorsky H-19-D helicopters purchased by the Army. Fixed-wing training also continued into the time period under study. Both types of aircraft training during this time were joined under a new command: the Army Aviation Unit Training Command (AAUTC). Operational by February 1955 at Marshall Field, the AAUTC was one of only two such commands in the Army; a second command was activated at Fort Sill in J uly 1955.

The Army Aviation: Fixed and Rotary-Wing Training theme under criterion $\mathrm{A}$ is significantly represented by the former simulator building (Building 720), the two hangars (Buildings 723 and 727), and the operations building (Building 725). Criterion Cis also met for Buildings 723 and 727 under the Army Aviation: Fixed and Rotary-Wing Training for their architectural significance. 


\subsubsection{Army Medicine: Hospital Integration (1958)}

Prior to the mid-1950s, Army medical hospital facilities consisted of older hospitals constructed in the early 1900s and 1920, and World War II temporary station hospitals. The temporary construction consisted of a large group of primarily one-story ward, laboratory, surgical, and office buildings spread out over a wide area with connecting covered walkways. With the war over, and medical technology advancing rapidly, there was a nationwide need for larger, more integrated hospital facilities. This led to a standard design for the "modern" Army hospital constructed at installations across the country. In order to integrate all medical activities under one roof, the resulting design called for a multi-story building. In 1953, York \& Sawyer of New York, New York submitted to the U.S. Army Corps of Engineers plans for a 500- to 1000-bed hospital which could be scaled down to fit local needs. This hospital had a large base to accommodate admitting, offices, supplies, and operating rooms. As the hospital went up in height, the architects stepped the building back to an elevator core and two ward wings. The total height of the building of the hospital was dependent on how many beds the installation needed. It was constructed out of concrete with large window canopies. At Fort Riley, the new hospital followed this standard plan and, like the others of its type, included stateof-the-art details such as a pneumatic tube distribution-communication system, and piped-in oxygen for critical treatment areas.

It was determined that Irwin Army Hospital (Building 600) and the associated heating plant (Building 615) built concurrently in 1957 were significant under NRHP Criterion A for illustrating the Army Medicine: Hospital Integration theme.

\subsubsection{Operation Gyroscope (1955-1959)}

Operation Gyroscope was a new system for troop rotation and replacement between the United States and overseas U.S. Army bases. Begun in 1955, the system did away with small unit exchanges and instituted rotations of battalions, regiments, or even entire divisions. In addition to unit size, this new system also allowed for families to accompany married personnel concurrently, and assigned soldiers to a particular unit for most of their military career. It was hoped that this new system would provide a higher level of troop morale, increased combat effectiveness, more integrated teamwork, and greater skill at mass troop movements. Fort Riley played an important role in this new system, having been selected to participate 
in the initial rotation. The $10^{\text {th }}$ Infantry Division moved to Germany as the 1st Infantry Division relocated to Fort Riley. The fort served as home base to both divisions when they returned from overseas deployments. Elements of the 1st Infantry Division returned to Germany in 1959, shortly before the Army discontinued the Gyroscope program. To house the division troops, more facilities were needed, and the development of the area known as Custer Hill was begun in 1955.

Of the structures built between 1956 and 1960 at Custer Hill for the 1st ID, significance resides in the buildings that exemplify the Operation Gyroscope training mission of the 1 st Division. Their work was conducted in the offices and motor pools utilized for training.

\subsubsection{Criterion B: Person}

The property is associated with the lives of persons significant in our past.

The available historical records provided no indication that the study properties were in any way associated with the life of an individual significant in U.S. history.

\subsubsection{Criterion C: Design/construction}

A property that embodies the distinctive characteristics of a type, period, or method of construction, or that represents the work of a master, or that possess high artistic values, or that represents a significant and distinguishable entity whose components may lack individual distinction.

The two aircraft hangars at Marshall Army Air Field (Buildings 723 and 727) individually characterize the distinctive characteristics of a type, period, or method of construction that is architecturally significant. These late 1950s hangars were part of a construction program launched by the Army to support their new air cavalry concept. This program was dominated by two standard hangar designs: Plan No. 39-01-62, entitled 12,000 Square Feet - 20,000 Square Feet with Shops, and Plan No. 39-01-64 for 20,000 Square Feet - 35,000 Square Feet with Shops. Both plans are essentially identical, with variation only in scale.

\subsubsection{Criterion D: Information potential}

The property has yielded, or is likely to yield, information important in prehistory or history. 
The available historical records provided no indication that the study properties have yielded, or were likely to yield, any information important in prehistory or history.

\subsubsection{State or local significance}

There is no indication in the available historical record that the buildings and structures surveyed have any significance in a local or state context. Designs indicate that most properties under study were of types constructed on a nationwide scale. Drawings for most of these buildings were produced by the Post Engineer, or the Kansas City or Omaha districts of the U.S. Army Corps of Engineers. The involvement of local architects, engineers, fabricators, and contractors to address site-specific conditions was standard practice at the time of construction and did not produce any variations or innovations of local or state significance.

\subsubsection{Significant buildings and structures}

After compiling the "Historic Context for Fort Riley Development, 18521963," (Chapter 2 of this report), the project team followed the important themes uncovered in that context to determine which buildings possess significance. For buildings covered in the 1993 survey report, please see Appendix D. Determinations of significance for the buildings covered in the 2007 and 2008 studies is found in Table 2 below.

Table 2. List of Significant/Not Significant Buildings.

\begin{tabular}{|c|c|c|c|c|}
\hline $\begin{array}{l}\text { Bldg. } \\
\text { No. }\end{array}$ & $\begin{array}{l}\text { Year } \\
\text { Built }\end{array}$ & Current Function & $\begin{array}{l}\text { Significant } \\
\text { Yes/No }\end{array}$ & Theme \\
\hline 198 & 1956 & WTR SUP/TRT BLD & $\mathrm{N}$ & \\
\hline 314 & 1957 & PROC MAINT FAC & $\mathrm{N}$ & \\
\hline 333 & 1948 & $\begin{array}{l}\text { ADMINISTRATION/SHOP } \\
\text { CONTROL (DOL/DPW) }\end{array}$ & $\mathrm{N}$ & \\
\hline 447 & 1955 & OUTDOOR SWIMMING POOL & $\mathrm{N}$ & \\
\hline 448 & 1949 & OUTDOOR SWIMMING POOL & $\mathrm{N}$ & \\
\hline 449 & 1949 & $\begin{array}{l}\text { OUTDOOR POOL SERVICE } \\
\text { BUILDING }\end{array}$ & $\mathrm{N}$ & \\
\hline 502 & 1959 & POLICE/MP STA & $\mathrm{N}$ & \\
\hline 600 & 1957 & MED CTR/HOSP & $\mathrm{Y}$ & Army Medicine \\
\hline 615 & 1957 & HEAT PLT BLDG & $\mathrm{Y}$ & Army Medicine \\
\hline 633 & 1931 & $\begin{array}{l}\text { INFORMATION SYSTEMS } \\
\text { PROCESSING CENTER }\end{array}$ & $\mathrm{N}$ & \\
\hline 720 & 1960 & $\mathrm{CO} \mathrm{HQ} \mathrm{BLDG}$ & $\mathrm{Y}$ & Army Aviation \\
\hline
\end{tabular}




\begin{tabular}{|c|c|c|c|c|}
\hline $\begin{array}{l}\text { Bldg. } \\
\text { No. }\end{array}$ & $\begin{array}{l}\text { Year } \\
\text { Built }\end{array}$ & Current Function & $\begin{array}{l}\text { Significant } \\
\text { Yes/No }\end{array}$ & Theme \\
\hline 721 & 1957 & SEW/WST WTR TRT & $\mathrm{N}$ & \\
\hline 723 & 1959 & STORAGE GP INST & $Y$ & Army Aviation \\
\hline 725 & 1960 & AVN UNIT OPS & $Y$ & Army Aviation \\
\hline 727 & 1957 & AC MAINT HGR & $\mathrm{Y}$ & Army Aviation \\
\hline 745 & 1958 & FLAM MAT STR IN & $\mathrm{N}$ & \\
\hline 747 & 1960 & PWR PLT BLDG & $\mathrm{N}$ & \\
\hline 1781 & 1960 & STORAGE GP INST & $\mathrm{N}$ & \\
\hline 1955 & 1955 & FLAM MAT STR IN & $\mathrm{N}$ & \\
\hline 1980 & 1949 & $\begin{array}{l}\text { REFUSE/GARBAGE BUILDING, } \\
\text { RECYCLING }\end{array}$ & $\mathrm{N}$ & \\
\hline 2101 & 1952 & COMMUNICATIONS CENTER & $\mathrm{N}$ & \\
\hline 2351 & 1960 & ENG/HOUSING MNT & $\mathrm{N}$ & \\
\hline 2592 & 1941 & $\begin{array}{l}\text { SEWAGE/WASTE TREATMENT } \\
\text { BUILDING }\end{array}$ & $\mathrm{N}$ & \\
\hline 2657 & 1960 & ENG/HOUSING MNT & $\mathrm{N}$ & \\
\hline 3200 & 1958 & WTR SUP/TRT BLD & $\mathrm{N}$ & \\
\hline 3201 & 1958 & WTR SUP/TRT/BLD & $\mathrm{N}$ & \\
\hline 3202 & 1937 & $\begin{array}{l}\text { WATER SUPPLY/TREATMENT } \\
\text { BUILDING (POTABLE) }\end{array}$ & $\mathrm{N}$ & \\
\hline 3203 & 1952 & $\begin{array}{l}\text { WATER SUPPLY/TREATMENT } \\
\text { BUILDING (POTABLE) }\end{array}$ & $\mathrm{N}$ & \\
\hline 3204 & 1943 & $\begin{array}{l}\text { WATER SUPPLY/TREATMENT } \\
\text { BUILDING (POTABLE) }\end{array}$ & $\mathrm{N}$ & \\
\hline 3205 & 1929 & $\begin{array}{l}\text { WATER SUPPLY/TREATMENT } \\
\text { BUILDING (POTABLE) }\end{array}$ & $\mathrm{N}$ & \\
\hline 4320 & 1957 & PLT/UTIL BLDG & $\mathrm{N}$ & \\
\hline 4604 & 1959 & PLT/UTIL BLDG & $\mathrm{N}$ & \\
\hline 5200 & 1960 & $\begin{array}{l}\text { WATER STORAGE TANK } \\
\text { (POTABLE) }\end{array}$ & $\mathrm{N}$ & \\
\hline 5201 & 1957 & WTR SUP/TRT/BLD & $\mathrm{N}$ & \\
\hline 6420 & 1960 & COMMO CTR & $\mathrm{N}$ & \\
\hline 6620 & 1963 & CHILD DEVELOPMENT CENTER & $\mathrm{N}$ & \\
\hline 6641 & 1956 & PLT/UTIL BLDG & $\mathrm{N}$ & \\
\hline 7024 & 1960 & PHYS FIT CTR & $\mathrm{N}$ & \\
\hline 7086 & 1959 & CHAPEL & $\mathrm{N}$ & \\
\hline 7165 & 1957 & DISPATCH BLDG & $\mathrm{Y}$ & Operation Gyroscope \\
\hline 7168 & 1957 & OIL STR BLDG & $\mathrm{Y}$ & Operation Gyroscope \\
\hline 7173 & 1957 & VEH MAINT SHOP & $Y$ & Operation Gyroscope \\
\hline 7174 & 1957 & VEH MAINT SHOP & $Y$ & Operation Gyroscope \\
\hline 7175 & 1957 & ENG/HOUSING MNT & $\mathrm{Y}$ & Operation Gyroscope \\
\hline
\end{tabular}




\begin{tabular}{|c|c|c|c|c|}
\hline $\begin{array}{l}\text { Bldg. } \\
\text { No. }\end{array}$ & $\begin{array}{l}\text { Year } \\
\text { Built }\end{array}$ & Current Function & $\begin{array}{l}\text { Significant } \\
\text { Yes/No }\end{array}$ & Theme \\
\hline 7176 & 1957 & ENG/HOUSING MNT & $Y$ & Operation Gyroscope \\
\hline 7243 & 1960 & CO HQ BLDG & $\mathrm{Y}$ & Operation Gyroscope \\
\hline 7264 & 1958 & ACS CTR & $\mathrm{N}$ & \\
\hline 7285 & 1960 & AUTO-AID INST & $\mathrm{N}$ & \\
\hline 7465 & 1963 & $\begin{array}{l}\text { SEPARATE TOILET/SHOWER } \\
\text { BUILDING }\end{array}$ & $\mathrm{N}$ & \\
\hline 7466 & 1963 & OUTDOOR SWIMMING POOL & $\mathrm{N}$ & \\
\hline 7467 & 1963 & $\begin{array}{l}\text { OUTDOOR POOL SERVICE } \\
\text { BUILDING }\end{array}$ & $\mathrm{N}$ & \\
\hline 7515 & 1956 & $\begin{array}{l}\text { WATER STORAGE TANK } \\
\text { (POTABLE) }\end{array}$ & $\mathrm{N}$ & \\
\hline 7710 & 1960 & RG/TTGT HOUSE & $\mathrm{N}$ & \\
\hline 8132 & 1956 & ENG/HOUSING MNT & $\mathrm{N}$ & \\
\hline 8133 & 1956 & $\begin{array}{l}\text { ENGINEERING/HOUSING } \\
\text { MAINTENANCE SHOP }\end{array}$ & $\mathrm{N}$ & \\
\hline 9008 & 1948 & $\begin{array}{l}\text { SEPARATE TOILET/SHOWER } \\
\text { BUILDING }\end{array}$ & $\mathrm{N}$ & \\
\hline 9081 & 1955 & RG/TGT HOUSE & $\mathrm{N}$ & \\
\hline 9158 & 1961 & RANGE SUPPORT BUILDING & $\mathrm{N}$ & \\
\hline 9165 & 1960 & RG/TGT HOUSE & $\mathrm{N}$ & \\
\hline 9166 & 1960 & SEP TOIL/SHOWER & $\mathrm{N}$ & \\
\hline 9185 & 1960 & RG/TGT HOUSE & $\mathrm{N}$ & \\
\hline 9186 & 1960 & SEP TOIL/SHOWER & $\mathrm{N}$ & \\
\hline 9389 & 1951 & OBSERVATION TOWER & Y & $\begin{array}{l}\text { Combat Training and } \\
\text { Army Schools }\end{array}$ \\
\hline
\end{tabular}

Buildings/ structures not found to be significant fall generally within one of three categories: (1) utilities; (2) morale, welfare and recreation (MWR); and (3) support. Utilities included buildings inventoried related to water/ sewer systems, and the telephone system. MWR facilities inventoried for this report included swimming pools and related buildings, field houses, and a child care center. Support buildings' original uses included motor pool dispatch facilities, warehouses, and a prefabricated building used for range support. None of these buildings/ structures were directly related to the significant historic themes. 


\subsection{Integrity assessment}

Once the research team determined which buildings were potentially significant, they analyzed the current conditions of the buildings for retention of character-defining features. They also evaluated the buildings for the ability to convey their significance through the seven aspects of integrity (Appendix A). In the 2007 and 2008 studies, it was determined that all but three buildings (720, 723, and 725) had lost sufficient aspects of integrity to render them unable to visually convey their significance (Table 3).

Table 3. Retention of Integrity.

\begin{tabular}{|c|l|l|l|}
\hline $\begin{array}{l}\text { Significant } \\
\text { Bldg No. }\end{array}$ & $\begin{array}{l}\text { Year } \\
\text { Built }\end{array}$ & Current Function & Retained Integrity Aspects \\
\hline 600 & 1957 & MED CTR/HOSP & Location; Setting; Association \\
\hline 615 & 1957 & HEAT PLT BLDG & Location; Setting; Association \\
\hline 720 & 1960 & CO HQ BLDG & ALL \\
\hline 723 & 1959 & STORAGE GP INST & ALL \\
\hline 725 & 1960 & AVN UNIT OPS & ALL \\
\hline 727 & 1957 & AC MAINT HGR & Location; Setting; Association \\
\hline 7165 & 1957 & DISPATCH BLDG & Location; Setting; Association \\
\hline 7168 & 1957 & OIL STR BLDG & Location; Setting; Association \\
\hline 7173 & 1957 & VEH MAINT SHOP & Location; Setting; Association \\
\hline 7174 & 1957 & VEH MAINT SHOP & Location; Setting; Association \\
\hline 7175 & 1957 & ENG/HOUSING MNT & Location; Setting; Association \\
\hline 7176 & 1957 & ENG/HOUSING MNT & Location; Setting; Association \\
\hline 7243 & 1960 & CO HQ BLDG & Location; Setting; Association \\
\hline 9389 & 1951 & OBSERVATION TOWER & Association (building moved in 1995) \\
\hline
\end{tabular}

\subsection{Determinations of Eligibility}

For the 2007 and 2008 studies, it was determined that only three buildings (720, 723, and 725) possessed both significance and sufficient integrity to be determined eligible to the NRHP (Table 4). Eligibility determinations for the buildings included in the 1993 survey and evaluation are in Appendix D. 
Table 4. Determinations of Eligibility to the NRHP.

\begin{tabular}{|c|l|l|l|l|l|}
\hline $\begin{array}{l}\text { Significant } \\
\text { Bldg No. }\end{array}$ & $\begin{array}{l}\text { Year } \\
\text { built }\end{array}$ & Current function & $\begin{array}{l}\text { Eligible } \\
\text { Yes/No }\end{array}$ & $\begin{array}{l}\text { NRHP } \\
\text { Criteria }\end{array}$ & $\begin{array}{l}\text { Integrity } \\
\text { Retained } \\
\text { Yes/No }\end{array}$ \\
\hline 600 & 1957 & MED CTR/HOSP & N & A & N \\
\hline 615 & 1957 & HEAT PLT BLDG & N & A & N \\
\hline 720 & 1960 & CO HQ BLDG & Y & A & Y \\
\hline 723 & 1959 & STORAGE GP INST & Y & A \& C & Y \\
\hline 725 & 1960 & AVN UNIT OPS & Y & A & Y \\
\hline 727 & 1957 & AC MAINT HGR & N & A \& C & N \\
\hline 7165 & 1957 & DISPATCH BLDG & N & A & N \\
\hline 7168 & 1957 & OIL STR BLDG & N & A & N \\
\hline 7173 & 1957 & VEH MAINT SHOP & N & A & N \\
\hline 7174 & 1957 & VEH MAINT SHOP & N & A & N \\
\hline 7175 & 1957 & ENG/HOUSING MNT & N & A & N \\
\hline 7176 & 1957 & ENG/HOUSING MNT & N & A & N \\
\hline 7243 & 1960 & CO HQ BLDG & N & A & N \\
\hline 9389 & 1951 & OBSERVATION TOWER & N & A & N \\
\hline
\end{tabular}

\subsection{Marshall Army Air Field}

Three buildings at Marshall Army Air Field (720, 723, and 725) were determined eligible for the National Register with significance under Criterion A: Event and Criterion C: Design. The buildings also retain sufficient integrity to visually represent their significance. These buildings are eligible due to their documented direct association with the expanding aviation training activities at Fort Riley during the latter half of the 1950s, particularly with the air mobility efforts underway at that time and with the AAUTC established first at Fort Riley in 1955.

These three eligible properties were also evaluated for possible inclusion in a historic district. The current Fort Riley Historic District is confined to the Main Post area. While the results of all three inventories show there are currently 20 eligible buildings at Marshall Field, there are too many non-contributing buildings among the eligible ones (which include 720, 723, and 725) for there to be a cohesive aviation district. If the Fort Riley Main Post Historic District boundaries are re-evaluated in the future, it would be useful to consider including the eligible Marshall Army Air Field buildings. 


\section{Recommendations for Organization and Management of Eligible Properties}

\subsection{Proposed historic districts}

An NRHP Historic District is defined as "...a geographically definable area...possessing a significant concentration, linkage, or continuity of sites, buildings, structures, and/ or objects united by past events or aesthetically by plan or physical development." Historic districts are usually areas of contiguous historic properties. The close proximity of the properties included in the district helps to maintain the sense of a coherent and related grouping that represents a specific time, period of time, or function. It was outside the scope of this report to define historic districts geographically that was done as part of the NRHP Main Post Historic District nomination. The 1993-1994 report suggested possible districts based on the close historical, functional, and stylistic association of structures, with geography as a major, but not overriding, consideration.

The Main Post National Historic District at Fort Riley covers 640 acres and contains over 500 buildings (Figure 42). Additionally there are 19 buildings outside the Main Post National Historic District that are either listed on the National Register of Historic Places or deemed eligible for listing. ${ }^{408}$

In the 1993 study, districts were proposed for eligible buildings at Fort Riley. The proposed districts contain some buildings with low levels of significance (a district rating of 4), such as garages. Although these structures individually make little significant contribution to their proposed district, they are constructed of appropriate building materials and are a functional aspect of their associated structure. If ever these buildings need to be replaced or modified, they should be replaced with similar structures that are also sympathetic to the historic environment. Other buildings with a district rating of 4 , such as open warehouses, are excluded as part of any

\footnotetext{
408 “Fort Riley and Junction City Kansas”, U.S. Army Office of Historic Property and Partnerships, http://www.asaie.army.mil/Public/Partnerships/OHP/achp-riley.htm
} 
proposed historic district because they make no discernable contribution. Simple demolition of these buildings should have no significant impact on any district. Descriptions of these proposed districts and their constituent buildings can be found in Appendix D.

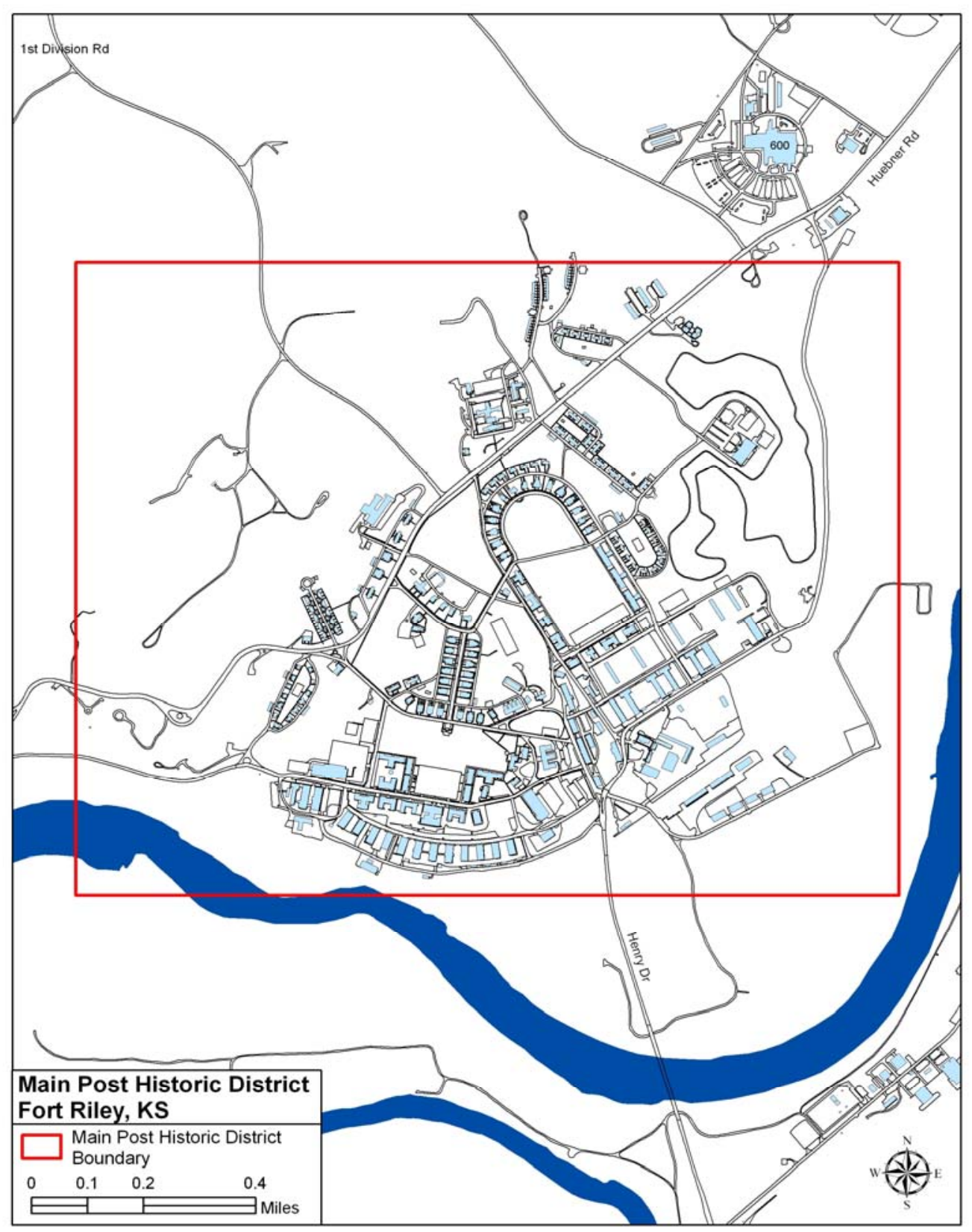

Figure 42. Map of Main Post showing Historic District boundaries (DPW, Fort Riley, Kansas) 
In 1994, the findings were revised into a new set of proposed districts organized around historical themes. These districts, themes, and associated buildings can be found in Appendix E. This is the organization used in 2008 to re-evaluate the integrity of the eligible buildings.

\subsection{Recommendations for the treatment and further research of historic structures at Fort Riley}

By and large, the historic structures at Fort Riley appear to be in remarkably good condition, with one exception from the historic perspective. That is that Fort Riley has not been spared the negative effects of poor replacement window and door choices, one of the most pervasive problems in the field of historic preservation. Such replacements tend to give the historic buildings to which they are applied an appearance that is dull and lifeless. This appearance is often referred to as "the blank stare look," for obvious reasons.

Although repair of existing windows and doors is preferable, the newer, more architecturally sensitive replacements may be installed in some buildings. These substitutions should be chosen for their similarity to the originals they are replacing. Such choices will greatly reduce the negative impact of necessary maintenance. For a full analysis of and complete set of recommendations for the treatment of windows in historic buildings, facilities managers may refer to the Secretary of the Interior's publication on the subject. 409

We recommend that a process be established whereby alterations (e.g. window replacement and re-siding) to historic structures at Fort Riley will be reviewed and assessed in light of the proposed alteration's impact on the integrity of the property and any historic district of which that building may be a part or may visually impact.

A problem common to military installations - the need to construct new buildings within historic districts - needs to be addressed so that these new buildings do not seem out of place and detract from the integrity of historic districts. New buildings can be designed to minimize negative effects on a historic district. Design elements such as massing, materials,

409 The Window Handbook: Successful Strategies for Rehabilitating Windows in Historic Buildings, A technical manual by the National Park Service and the Georgia Institute of Technology. Available from the Historic Preservation Education Foundation, P.O Box 27080, Central Station, Washington D.C. 20038-7080 
colors, roof type, and others can be manipulated so that new construction will be less intrusive than buildings designed without regard for the historic environment. Much like the art of camouflage - where one does not attempt to look like a tree but rather to blend in with the trees - new buildings, while not attempting to recreate or mimic the historic style, can be designed in such a way that they appear to fit into their historic surroundings.

We recommend that a process be established whereby the design of new buildings, in close proximity to historic structures, be reviewed and assessed for their appropriateness in relation to the surrounding historic district.

The assessments of the condition of the buildings documented in this report were made from a very fast and cursory observation of the buildings. We recommend that a more complete and intensive study be made of the physical condition of all the structures documented in this report to identify the original and significant architectural features of the structures.

Following the completion of a Condition Assessment, a Maintenance Plan should be formulated to ensure that the historic structures at Fort Riley will be supported and preserved for years to come.

\subsection{Recommendation Summary}

1. Facilities managers should follow Secretary of the Interior Standards for window and door replacement in historic buildings.

2. An in-house process should be established to review proposed alterations to historic buildings and to review the design of new buildings to be located near historic buildings in order to minimize negative impacts from these alterations and any new construction.

3. A Condition Assessment should be made for all buildings documented in this report.

4. A Maintenance Plan should be formulated for all buildings documented in this report.

5. If the Fort Riley Main Post Historic District boundaries are reevaluated in the future, it would be useful to consider including the eligible Marshall Army Air Field buildings. 


\section{Bibliography}

\section{Books, manuscripts, and government publications 410}

1st Infantry Division and Fort Riley Information Office. First Infantry Division Yearbook: 41st Anniversary, 1917-1958. Fort Riley, Kansas: U.S. Army, 1958.

Advisory Council on Historic Preservation. Program Comment for Capehart and Wherry Era Army Family Housing and Associated Structures and Landscape Features (1949-1962). Washington, DC: Federal Register. Vol. 67, No. 110, J une 7, 2002.

Anonymous. "The Growth and Building History of Fort Riley." n.p. Anonymous manuscript on file at Kansas State Historical Society, Topeka, Kansas.

*Andros, Pamela, Dan Lapp, Mira Metzinger, Patrick Nowlan, Carla Spradlin, Steve Turner, and J ulie Webster. Historical and Architectural Documentation Reports for Fort Riley, Kansas. Champaign, IL: Construction Engineering Research Laboratory, 1993; Revised 1994.

Crawford, Catherine. Changing Plan of Fort Riley Historic American Building Survey. Washington, D.C.: National Park Service, 1985.

Department of the Army. Pamphlet 415-28: Guide to Army Real Property Category Codes. Washington, D.C.: Headquarters, Department of the Army, 2006.

. "Construction Item J ustification Data." n.p. Record Group 77, Entry 203, MC Army PROG FLS BX 37-40, 54-62, Box 39, Folder: Medical. National Archives and Records Administration, College Park, MD, 25 April 1960.

. "Construction Item J ustification Data." n.p. Record Group 77, Entry 242, Box 8: 1958 FY, Folder: Item J ustification. National Archives and Records Administration, College Park, MD, 15 Nov 1957.

. “Construction Item J ustification Data,” n.p. Record Group 77, Entry 242, Box 7: FY 1958, Folder: J ustification Book 1956. National Archives and Records Administration, College Park, MD, 1Sep 1956.

Dunn, Lt. Gen. Carroll H. Vietnam Studies: Base Development in South Vietnam, 19651970. Washington, D.C.: Department of the Army, 1991.

Engleman, Rose C., ed. A Decade of Progress: The United States Army Medical Department, 1959- 1969. Chapter 3: "Modernization of Facilities and Equipment." Washington, D.C.: Office of the Surgeon General, Department of the Army, 1971.

"Fort Riley: Its Historic Past." Washington, DC: Center for Military History. Vertical File: “228.03 HRC 331 Posts - Riley, Fort.” ca. 1973.

\footnotetext{
410 Reference entries preceded by an asterisk were not published for access by the general public; read-
} ers may contact the issuing organization for further information. 
Fort Riley Department of Public Works. Building Directory. Fort Riley, Kansas: Department of Public Works, 2006.

. DA Form 2877, Real Property Record. Fort Riley, Kansas: Department of Public Works, n.d.

. Drawings on file.

. War Department Form 5-47. Real Property Record - Buildings. Fort Riley, Kansas: Department of Public Works, n.d.

Garner, J ohn S. World War II Temporary Military Buildings: A Brief History of the Architecture and Planning of Cantonments and Training Stations in the United States. USACERL Tech Report CRC-93/ 01. Champaign, IL: U.S. Army Corps of Engineers, Construction Engineering Research Laboratories, 1993.

* Goodwin, R. Christopher \&Associates, Inc. National Register Assessment of Buildings 7033, 7034, 7036, and 7215, Custer Hill Troop Area, Fort Riley, Kansas.

Frederick, MD: R. Christopher Goodwin \&Associates, Inc., 2007.

Headquarters, Fort Riley, Kansas. General Orders Number 112, “Memorialization.” 5 May 1967. Vertical File, “Building 7024.” Department of Public Works, Fort Riley, Kansas.

Headquarters, United States Continental Army Command, Fort Monroe, VA to Deputy Chief of Staff for Logistics, Department of the Army, Washington, DC, 12 J une 1957. Record Group 337, Entry \#3 (UD-WW), Box 37, Folder: 600 Binder \#3. National Archives and Records Administration, College Park, MD.

Hermes, Walter G. American Military History, Chapter 27: "Global Pressures and the Flexible Response." Washington, D.C.: US Army Center of Military History, U.S. Army, 1989.

"History of Fort Riley, Kansas." Record Group 77, Entry 242, Box 8, Folder: Armies \& MDW Comments. National Archives and Records Administration, College Park, MD.

J ohnson, Charles William. The Civilian Conservation Corps: The role of the Army, Doctoral dissertation, University of Michigan, 1968.

Kuranda, Kathryn M., et al. Unaccompanied Personnel Housing (UPH) During the Cold War (1946-1989). Frederick, Maryland: R. Christopher Goodwin \&Associates, Inc. for the U.S. Army Environmental Center. Aberdeen Proving Ground. Maryland, 2003.

. Housing an Army: The Wherry and Capehart Era Solutions to the Postwar Family Housing Shortage (1949-1962), Aberdeen Proving Ground, MD: U.S. Army Environmental Center, 2003.

Lane, David A., Robert Gumerove, and Elizabeth W. Hotlzworth. Operation Gyroscope in the United States Army, Europe. Headquarters, United States Army, Europe, Historical Division, 1957. 
Mariani \&Associates Architects, Study/ Survey of Historically Significant Army Family Housing Quarters, V.I, (Installation Report, Fort Riley, Kansas, J une, 1988).

McAlester, Virginia, and Lee McAlester. A Field Guide to American Houses Alfred A. Knopf, Inc.: New York, 1991.

McCarthy, Sheila A. and Roy L. MoCullough. Fort Hood Military Family Housing of the Cold War Era: McNair Village \& Chaffee Village. Omaha, NE: Midwest Regional Office, National Park Service, 2003.

Meyerson, J oel D. United States Army in Vietnam: Images of a Lengthy War. Washington, D.C.: US Army Center of Military History, 1986.

Murphey, J oseph et al. Army Ammunition and Explosives Storage in the United States, 1775-1945. Fort Worth: U.S. Army Corps of Engineers Fort Worth District, 2000.

*Nowlan, Patrick. Identification and Evaluation of Cold War Properties at Fort Bliss, Texas. Champaign, Illinois: U.S. Army Construction Engineering Research Laboratory, 1999.

Office of the Chief of Military History. American Military History, Chapter 26: The Army and the New Look, rev .ed. Washington, D.C.: United States Army, 1988.

*Pedrotty, Michael A, J ulie L. Webster, Gordon L. Cohen, and Aaron R. Chmiel. Historical and Architectural Overview of Military Aircraft Hangars: A General History, Thematic Typology, and Inventory of Aircraft Hangars Constructed on Department of Defense Installations. Langley AFB, VA: HQACC, September 1999, Revised May 2001.

Pride, W. F. The History Of Fort Riley U.S. Cavalry Museum and Fort Riley Historical and Archeology Society, 1926.

R. Christopher Goodwin and Associates. Neighborhood Design Guidelines for Army Wherry and Capehart Era Family Housing. Aberdeen Proving Ground, MD: U.S. Army Environmental Center. 2003.

Real Property Records on file at the Directorate of Engineering and Housing, Fort Riley, Kansas.

Robinson \&Associates, Fort Riley: An Historic Overview, V.I. [Report prepared for U.S. Army Corps of Engineers, Kansas City District], (Washington, DC, October 1989).

Schooley Caldwell Associates, Installation Design Guide: Fort Riley [Preliminary Submission], 1987.

Spector, Ronald H. Advice and Support: The Early Years 1941-1960. Washington, D.C: US Army Center of Military History, United States Army, 1983.

U.S. Army Corps of Engineers Office of History. 105mm Negatives - Building Plans and Specifications. Fort Belvoir, VA: USACE HQ, Office of History, n.d.

U.S. Department of the Interior. National Park Service. National Register Bulletin: How to Apply the National Register Criteria for Evaluation. Washington, DC. 1997. 
U.S. House, Committee of Conference. Construction at Military Installations. $80^{\text {th }}$ Cong., $2^{\text {nd }}$ sess. House Report 80-2141. Washington, D.C.:GPO, 1948.

U.S. House, Committee on Appropriations. Military Establishment Appropriation Bill for 1947: Hearing Before the Subcommittee on the Committee on Appropriation. 79th Cong., $2^{\text {nd }}$ sess. Washington D.C.:GPO, 1946.

U.S. House, Committee on Appropriations. Military Functions, National Military Establishment Appropriation Bill for 1949: Supplemental Hearing Before the Subcommittee of the Committee on Appropriations. 80th Cong., $2^{\text {nd }}$ sess. Washington D.C.:GPO. 1948.

U.S. House, Committee on Armed Services. Full Committee Hearings on H.R. 7008 and S. 2440 to Authorize Certain Construction at Military and Naval Installations, and For Other Purposes: Hearings Before the committee on Armed Services of the House of Representatives on Sundry Legislation Affecting the Naval and Military Establishments 1950. 81 ${ }^{\text {st }}$ Cong., $2^{\text {nd }}$ sess, No. 180. Washington D.C.:GPO. 1951.

U. S. Senate. "Investigation of the Preparedness Program, Twenty-Fourth Report of the Preparedness Subcommittee of the Committee on Armed Services, United States Senate: Fort Riley, Kans." Washington, DC: GPO, 1951

U.S. War Department, Adjutant General's Office, "Station and Strength Report of the Civilian Conservation Corps," November 30, 1933.

U.S. War Department. Post War Utilization Studies: Fort Riley, Kansas. Washington, DC: Office of the Chief of Engineers, 1945.

Webster, J ulie L. "Fort Riley Building Inventory Field Forms." Champaign, IL: ERDCCERL, 2008.

Webster, J ulie L. Fort Riley Building Inventory 1953-1960 Field Forms. Champaign, IL: ERDC-CERL, 2007.

Weinert, Richard P., Jr. A History Of Army Aviation - 1950-1962. Fort Monroe, Virginia: Office of the Command Historian, U.S. Army Training and Doctrine Command, 1991.

\section{Communications}

Fechet, J . E. Chief of the Air Corps, Letter to Adjutant General, April 18, 1928.

Henry, Guy V. Brigadier General, U.S. Army, Commandant, Memo to Colonel F.C. Harrington, Asst. Administrator, Works Progress Administration, 10 April 1936, National Archives, Washington, D.C., RG 69, Entry 651.101, Box 1360.

Roosevelt, President Franklin D., 32nd President of the United States. "Creating Machinery for the Works Progress Administration," Executive Order No. 7034, May 6, 1935.

Smith, Harry A., Major General. U.S. Army, Commanding, Letter to Adjutant General, Washington, D.C. J anuary 17, 1928. 
“Welcome to Fort Riley,” circa 1965. Vertical file: 228.03 HRC 331 Posts - Riley, Fort, Center for Military History, Washington, D.C.

Wilson, Arthur R., Lt. Colonel. General Staff Corps, Memo to Assistant Chief of Staff, November 3, 1941.

\section{Periodicals}

“18-Year Olds to Post.” J unction City Union. 10 August 1948.

"8th Infantry Trainees Enter Final Phase of Training Before Overseas Shipment." The Fort Riley Post. 20 J anuary 1961.

“1st Division Welcome Set At New York.” J unction City Union. 19 J uly 1955.

“4th Cavalry Gets Helicopter Unit.” The Fort Riley Post. 2 J uly 1964.

“1,900 ROTC Cadets To Train at Fort Riley.” The Fort Riley Post. 13 February 1964.

“1958 Proves Successful Year at Fort Riley.” The American Traveler. 5J anuary 1959.

“75 Generals to Visit Post.” The Fort Riley Post. 11 December 1964.

“\$600,000 NCO Club To Open Monday Noon.” The Fort Riley Post. 20 December 1963.

“10th Division Troops Start On Gyro Trip.”J unction City Union. 29 J une 1955.

"13th Infantry Airlifted to Germany Monday." The Fort Riley Post. 5 October 1962.

“37th Division To Be The 10th.”J unction City Union. 8 May 1954.

“37th Infantry Division Likely to Get New Name.” J unction City Union. 16 February 1954.

"12th in Berlin, 13 th to Germany." The Fort Riley Post. 28 September 1962.

“2500 Citizen-Soldiers Begin Training in J une.” The Fort Riley Post. 29 March 1963.

“26th Infantry Becomes Part of 1st Division.” The Fort Riley Post. 8 February 1963.

“A New Fort Riley Era.”J unction City Union. 21 October 1946.

“Aerial School At Fort Riley.” J unction City Union. 1 March 1946.

“Air Force Personnel Training At Fort Riley NCO Academy.” The Fort Riley Post. 9 November 1961.

“Air Force Wing to Support Division.” The Fort Riley Post. 22 March 1963.

“Approve Fort Housing Plan.” J unction City Union. 9 December 1946.

“Areas Are Named for Men of 1st.” The Fort Riley Post. 5 April 1963.

“Army Building Teams Complete 344 Family Units at Riley.” J unction City Union. 27J uly 1950. 
“Army Finds Need For Marshall Field.” J unction City Union. 20 J uly 1950.

“Army General School Is Growing Rapidly.”J unction City Union. 10 October 1950.

"Army General School Is The Successor to Cavalry School." J unction City Union. 24 J une 1953.

“Army General School Nears Its 64th Year at Fort Riley.” J unction City Union. 24 February 1955.

"Army Helicopters Will Be Assembled Here, Then Flown To New Assignments." Guidon. 20 August 1952.

“Army Idea Makes Progress.” The Fort Riley Post. 17 February 1961.

“Army Is Nearing Planned Strength.” J unction City Union. 26 J une 1951.

“Army’s Marksmanship Program Under Study.” The Fort Riley Post. 21J uly 1961.

“Army Orders Air Training Unit at Post.”J unction City Union. 21July 1955.

“Army Organization First ROAD Type Divisions.” The Fort Riley Post. 2 February 1962.

“Army Preparation for First Division's Shift to Fort Riley Are Well Underway.”J unction City Union. 25 April 1955.

“Army Reviews Its Top Stories In 1961 News.” The Fort Riley Post. 29 December 1961.

“Army Stresses New Weapons Concept in 60.” The Fort Riley Post. 6 J anuary 1961.

“Army to Call Reservists.”J unction City Union. 4 August 1950.

“Army to Resume 16 Weeks Basic Training.” J unction City Union. 19 J une 1951.

“Army Will Enlarge Field Force Schools.” J unction City Union. 16 March 1950.

“Army Will Open 11 Training Centers.”J unction City Union. 17 August 1950.

“Ask \$7,413,000 for Fort Riley Housing.” J unction City Union. 7 April 1954.

“Ask 3 Million Man Force.”J unction City Union. 2 September 1950.

“Basic Training to be 14 Weeks.” J unction City Union. 19 February 1949.

“Bid on New Fort Housing October 25.” J unction City Union. 4 October 1954.

“Bids for Post Gym Sept. 23.”J unction City Union. 15 September 1947.

“Bids Opened On HousingJ ob at Post.” J unction City Union. 26 April 1955.

“Bird's-Eye View of 1962.” The Fort Riley Post. 28 December 1962.

“Bivouac Training A Realistic Review of Soldier's Lessons.” J unction City Union. 7 August 1953. 
“Boost Draft by 80,000.”J unction City Union. 28 J uly 1950.

“Bridge Construction in Full Swing." The Fort Riley Post. 19 April 1963.

“Bridge Dedicated as Memorial To Soldier.” The Port Riley Post. 1 May 1964.

“Brigade Strength Army Begins Florida Exercises.” The Fort Riley Post. 4 September 1964.

Brinkerhoff, J ohn R. “A history of unit stabilization.” Military Review. May-J une. 2004.

“Broaden Courses at Cavalry School.”J unction City Union. 26 J anuary 1946.

“Building Funds For Fort Riley Reduced in Senate.”J unction City Union. 7J uly 1954.

“Bunkers, Trenches, Add Realism to Training at Fort.” J unction City Union. 14 February 1953.

"Bunkers, Trenches, Add Realism to Training at Fort." J unction City Union. 14 February 1953.

“Call Reserves to Duty.” J unction City Union. 20 J uly 1950.

“Camp Funston Field House to Be Opened Friday Evening." J unction City Union. 30 November 1950.

“Camp Moon Area at Fort Riley is Popular for Family Picnics.” The Fort Riley Post. 30 June 1961.

“Can Handle Draftees.” J unction City Union. 12 J uly 1950.

“Carlson Backs Military Building.” J unction City Union. 12 J uly 1954.

“Cavalry Memorial Dedication Highlight Organization Day.” The Fort Riley Post. 16 J une 1961.

“Chapel Renamed for Hero.” Fort Riley Post. 8 November 2001.

“Col. Balliett Officially Opens Custer Hill Gym.” Fort Riley Post. 16 September 1960.

“Colonel Comfort to Aggressor Exercises.” J unction City Union. 25 February 1953.

“Copter Unit To Fort Riley.”J unction City Union. 31J uly 1953.

“Construction, Repair Involves Firms to Total Nearly \$5 Million.” J unction City Union. 18 October 1951.

“Date Set for Hospital Bids.”J unction City Union. 16 March 1955.

“Defense Department Asks 11 Millions for Projects at Riley.” J unction City Union. 20 April 1955.

“Discharges to Inductees.” J unction City Union. 25 October 1949. 
“Division Needs 15,420 Crates for Overseas Move.” J unction City Union. 9 April 1955.

“Double U.S. Armed Force.” J unction City Union. 21 March 1951.

“Draft is in Motion Today.” J unction City Union. 11J uly 1950.

“Draft Law Accepted.”J unction City Union. 27J une 1950.

“Draft Measure Becomes Law.”J unction City Union. 25J une 1948.

“Eagles' Prepare for 'Long Thrust'.” The Fort Riley Post. 12 J uly 1963.

“Ease Off on Mobilization.”J unction City Union. 27 October 1950.

“Exercise 'Big Blast XIV' Starts Today At Fort Sheridan.” The Fort Riley Post. 27J anuary 1961.

“Exercise to Include 12 Riley Units.” The Fort Riley Post. 20 March 1964.

“Expect 1,800 From the 37th.”J unction City Union. 7 May 1954.

“Explosion Damages Gym At Funston.” The Fort Riley Post. 13 J anuary 1951.

“Fear Heavy Flood Damage at Post.” J unction City Union. 11J uly 1951.

“Field House is Approved.” J unction City Union. 22 J uly 1947.

“Fifth Army School At Fort Riley Is Two Years Old.” J unction City Union. 30 J uly 1953.

“First AOC Class Opens.” J unction City Union. 30 J une 1947.

“First Apartments at Post in October.” J unction City Union. 15 September 1947.

“First Cycle Over For 12th Infantry Recruits.” The Fort Riley Post. 10 February 1961.

“First Div. Became STRAC Last Friday.” The Fort Riley Post. 2 March 1962.

“First Division Group Due at Post Monday.”J unction City Union. 21J uly 1955.

“First Division Signal School.” The Fort Riley Post. 21 September 1962.

"First Division Units Training at Pike National Forest." The Fort Riley Post. 9 November 1961.

“First Draftees Meet the Army.” J unction City Union. 19 August 1950.

“First Mojave Helicopter Arrives.” The Fort Riley Post. 19 October 1962.

“First Receptees Arrive At Fort Riley’s New Reception Station For Processing.” The Fort Riley Post. 6J anuary 1961.

“Flood to New Heights.” J unction City Union. 12 J uly 1951.

“Foreign Officers To Visit Fort Riley.” The Fort Riley Post. 16 August 1963. 
“Fort Housing Assured.” J unction City Union. 24 J une 1950.

“Fort Loss \$6,000,000.”J unction City Union. 16 J uly 1951.

“Fort Riley and Marshal Field Having Leading Roles in Maneuvers." J unction City Union. 11 May 1948.

“Fort Riley Army Air Repair Group Will Go to Bragg.” J unction City Union. 23 March 1954.

“Fort Riley Aviation Unit Gets New Iroquois Helicopters.” The Fort Riley Post. 10 April 1964.

“Fort Riley Entering Era Of Greatest Growth.”J unction City Union. 29 April 1955.

“Fort Riley Housing Bill to the House.” J unction City Union. 13J anuary 1948.

“Fort Riley Ideally Located for Carrying Out Activities.” J unction City Union. 9 November 1949.

“Fort Riley News.” J unction City Union. 5 August 1948.

“Fort Riley News.” J unction City Union. 14 September 1948.

“Fort Riley Personnel To Take Part in Exercise ‘Big Blast XIV' J an. 27-29.” The Fort Riley Post. 20 J anuary 1961.

“Fort Riley to Honor Memory of Gen. Patton.” J unction City Union. 16 March 1946.

"Fort Riley Will Host the Largest ROTC Summer Encampment in the Nation." The Fort Riley Post. 16J une 1961.

"Fund of \$5,900,000 Assured for New Fort Riley Hospital." J unction City Union. $9 \mathrm{~J}$ une 1955.

"Funston Depot Quits J an. 20: Colonel Proctor Announces Termination of Replacement Depot."J unction City Union. 11J anuary 1946.

“General 'Tke' Visits Riley: Army Chief of Staff Makes Three Hour Inspection At Post.” Junction City Union. 15 February 1946.

“General's Strike Opens Funston Bowling Lanes.” The Fort Riley Post. 1 November 1963.

“Golf Driving Range Open at Fort Riley.”J unction City Union. 30 August 1947.

"Golf Pro, Reduced Rates Highlight Opening of Driving Range Tonight." The Fort Riley Post. 13 September 1963.

“Ground Breaking Marks Start of Housing Project in Custer Hill Area.” The Fort Riley Post. 7 April 1961.

"Guards are Due Sunday: Expect 7,200 Soldiers at Camp Funston for Summer Training." J unction City Union. 6 August 1948. 
“Hail Signing of Draft Law,”J unction City Union. 19 J une 1951.

“Have Division Will Travel.” The Fort Riley Post. 17 August 1962.

“Heavy Housing Need.” J unction City Union. 16 J uly 1948.

“Helicopter Battalion To Be Activated Soon.” J unction City Union. 14 J uly 1954.

“Helicopter Pilots Train at Fort Riley Where Cavalry Units Once Were Supreme." Junction City Union. 18 March 1955.

"In Tribute to Patton: Secretary of War Praises late General at Colorful Ceremony Dedicating Patton Hall at Fort Riley." J unction City Union. 4 April 1946.

“Irwin USAH To Celebrate2nd Birthday.” Fort Riley Post. 12 February 1960.

“Kansas’s Sixth Largest city Altered By Crisis.” The Fort Riley Post. 9 February 1962.

“Largest AOC Class To Graduate Friday.” J unction City Union. 31 August 1949.

“'Last Salute' Review Will Mark Close of Army School.” J unction City Union. 28 April 1955.

“'Longthrust VII' Completed; 13th Back Home.” The Fort Riley Post. 12 April 1963.

“Maneuvers Begin In The Carolinas.” The Fort Riley Post. 10 August 1962.

“Many Post Units Conduct Schools in Special Skills.” The Fort Riley Post. 22 September 1961.

“Marshall Field From the Air.”J unction City Union. 9 November 1949.

MoGinley, J oseph P. “U.S. Army and Air Force Wings Over Kansas, Part Two.” The Kansas Historical Quarterly. Vol. XXV. Autumn 1959, 3:334-360.

“Members of 37th Due to Arrive Tonight.” J unction City Union. 4 March 1954.

“Mobilization at a Glance.”J unction City Union. 20 J uly 1950.

“Mont Green to Build Apartments at Post.”J unction City Union. 18 J une 1949.

“NCO Academy To Train Area Students.” The Fort Riley Post. 11 September 1964.

“New Air Unit Sent to Post.”J unction City Union. 2 J une 1955.

“New Army School to Open Monday.” J unction City Union. 5 March 1953.

“New Center Opens Monday.” J unction City Union. 11 October, 1946.

"New Dike May Save Another Extended Bivouac for Division." (Fort Riley) Guidon. 12 March 1952.

"New Facilities Opened at Fort: Indoor Gold Driving Range Ready for Use; New Bowling Alleys in Use Saturday." J unction City Union. 21 December 1948. 
“New Group to Camp Funston,” J unction City Union. 2 October 1946.

“New Field House Almost Completed.” J unction City Union. 23 November 1948.

“New Fishing Lake Planned Here.” The Fort Riley Post. 27 April 1962.

“New Housing Units Nearing Completion. J unction City Union. 5 December 1950.

“New Lake Attracts Post Fishermen.” The Fort Riley Post. 7J uly 1961.

"New NCO Club. Luxurious Spaciousness Featured." The Fort Riley Post. 3J anuary 1964.

"New Post Exchange Adds To Custer Hill Expansion Program." Fort Riley Post. 12 August 1960.

“New Shop At Fort Riley.” J unction City Union. 4 February 1953.

“New Skeet Ranger Ready at Forsyth.”J unction City Union. 15 September 1947.

“New Unit to Air Base.” J unction City Union. 31 August 1949.

"New Use for Fort Riley: Leavenworth and Fort Snelling Reception Centers To Be Moved Here.”J unction City Union. 28 J uly 1946.

“Non Coms Plan New Open Mess On Custer Hill.” The Fort Riley Post. 11 May 1962.

Omer, George E. J r. "An Army Hospital: From Dragoons to Rough Riders - Fort Riley, 1953-1903." Kansas Historical Quarterly 23:4, Winter 1957, 337-367. . "An Army Hospital: From Horses to Helicopters - Fort Riley, 1904-1957." Kansas Historical Quarterly 24:1, Spring 1958, 57-78.

“One of Nation’s Top Military Posts.”J unction City Union. Centennial Edition, 24 J une 1953.

“Open Bids for Work at Post.”J unction City Union. 28 April 1947.

“Open Post Housing.” J unction City Union. 12 J anuary 1951.

“Operation Gyroscope Gains Momentum As First Division Prepares for Shift.” J unction City Union. 21 March 1955.

“Original Units Rejoin 'Fighting First'.” The Fort Riley Post. 4 October 1963.

“Pictorial Review of 1961 at Fort Riley.” The Fort Riley Post. 5J anuary 1962.

“Pandemic.” The Manhattan Mercury. 1 March 1998.

“Panel Okays Fort Riley Construction.” J unction City Union. 30 J une 1955.

“Plan a New Headquarters.”J unction City Union. 12 J une 1947.

“Plan Further Post Changes.” J unction City Union. 23J anuary 1948. 
“Plans To Build Hospital at Fort Riley Are on Schedule." J unction City Union. 25 February 1953.

“Post Flood Rehabilitation Open to Visitors' Inspection.” (Fort Riley) Guidon. 14 May 1952.

“Post Headquarters Moving Into New Building Today." J unction City Union. 11J une 1948.

“Post Receives First H-34 Helicopters.” The Fort Riley Post. 29 September 1961.

“Post Units to Maneuvers.”J unction City Union. 12 J anuary 1949.

"Post Will Again Support Summer Reserve and National Guard Training." The Fort Riley Post. 20 J anuary 1961.

“Praise for Army Schools.” J unction City Union. 14 August 1947.

“Progress On Housing.”J unction City Union. 29 J uly 1950.

"Ready for Dedication: Secretary of War, Robert P Patterson to Arrive at Fort Riley Today."J unction City Union. 3 April 1946.

"Recalls Days at Fort Riley: President Truman Comments on Training as Field Artilleryman.”J unction City Union. 20 September 1948.

“Reception Center Open.” J unction City Union. 25J uly 1946.

“Reception Center To Be Expanded.” J unction City Union. 20 J uly 1953.

“'Red One' and Two Other Divisions will Convert To Combat Ready Units." The Fort Riley Post. 11 August 1961.

“Riley Funds Are Mostly For Housing.” J unction City Union. 21 April 1955.

“Riley to Get New Mojave Helicopter.” The Fort Riley Post. 5 October 1962.

“River Stages Falling.”J unction City Union. 13J uly 1951.

“Rivers on a Rampage.” J unction City Union. 11J uly, 1951.

“Seek Bids For New NCO Club On Custer Hill.” The Fort Riley Post. 27J uly 1962.

“Soldier Talent Provides Tribute to the Cavalry.” The Fort Riley Post. 16 J une 1961.

"Strength Buildup Head the List of 1961 Military News Events." The Fort Riley Post. 29 December 1961.

"Students at Post Taking Course in Chemical Warfare." J unction City Union. 26 March 1951.

“Submit New Bids For Post Gymnasium.” J unction City Union. 11 November 1947.

“Tells Plans For Tenth.” J unction City Union. 5 November 1948. 
“Tenth Division to Receive Draftees.” J unction City Union. 20 J uly 1950.

"Tenth Infantry Division, 10,000 Strong, Now Moving into Second Year on Its Mission of Training Young Men in Peacetime Army." J unction City Union. 9 November 1949.

“The Fort Telephone System is Presently Undergoing Change." (Fort Riley) Guidon. 8 October 1952.

“The Life of Riley." San Diego: Military Publishers, 1974. Vertical File, Center for Military History, Washington, D.C.

“The National Guard Called.” J unction City Union. 21J uly 1950.

“The Use of Ground Units.”J unction City Union. 30 J une 1950.

“Three of 18 New Helicopters On Oder Delivered." J unction City Union. 19 November 1953.

“To Finish Camp Funston Field House.”J unction City Union. 9 May 1950.

“To Start on Fort Housing.” J unction City Union. 5J une 1947.

“To Train for 14 Weeks.”J unction City Union. 12 J uly 1950.

“Training of Combat Infantry Mission of the Tenth Division." J unction City Union. 24 June 1953.

“Transportation Corps to Observe 11' Anniversary.” J unction City Union. 30 J uly 1953.

“Troops in by Airlift.”J unction City Union. 1J uly 1950.

“Truman Could Call 600,000 Under Draft.” J unction City Union. 28 J une 1950.

“Truman Pays Tribute.”J unction City Union. 4 April 1946.

"Two On-Post Exercises Slated for This Fall: Will Be Held in Late October, midNovember." The Fort Riley Post. September 1962.

“Two Weeks Added to Training Cycle.” J unction City Union. 6 J uly 1951.

“Welcome to Fort Riley.” circa 1965. Vertical file: "228.03 HRC 331 Posts - Riley, Fort.” Center for Military History. Washington. D.C.

“What a Difference 8 Months Made.” (Fort Riley) Guidon. 12 March 1952.

“Why All The Emphasis On Guerilla Warfare.” The Fort Riley Post. 16 March 1962.

“Will Ask Bids of Barracks Conversions.” J unction City Union. 13 March 1947.

“Wind, Rain Lash Area.” J unction City Union. 10 J uly 1951.

“Wichita Firm Bids \$5,488,116 on Fort Riley Hospital.” J unction City Union. 21J une 1955. 
“Wichita Firm Gets Contract For Hospital.” J unction City Union. 29 J une 1955.

“Work Progressing Rapidly on Custer Hill Housing Project for Troops at Ft. Riley." Junction City Union. 2 April 1955.

“Work Started on \$5,488,116 Fort Riley Station Hospital.” Junction City Union. 19 J uly 1955.

“Worst Flood Is Feared.” J unction City Union. 11J uly 1951.

\section{Internet-based sources}

Advisory Council on Historic Preservation. "Program Comment for Cold War Era Unaccompanied Personnel Housing (1946-1974)." $2006 \mathrm{a}$. http://www.achp.gov/progalt/DoD\%20UPH\%20program\%20comment.pdf (accessed September 2009).

Advisory Council on Historic Preservation, "Program Comment for World War II and Cold War Era (1939-1974) Ammunition Storage Facilities." 2006b. http://www.achp.gov/progalt/DoD\%20ammo\%20storage\%20program\%20comment.pdf (accessed September 2009).

"An Overview of the U.S. Army in the Korean War 1950-1953." http://www.army.mil/features/KoreanWar/textversion.html (accessed September 2009).

"The Korean War: Narratives Extracted from CMH Commemorative Posters." http://www.army.mil/cmh-pg/reference/Korea/kw-narr.htm (accessed September 2009).

Army Historical Series, "The Korean War, 1950-1953," in American Military History. http://www.history.army.mil/books/AMH/AMH-25.htm (accessed September 2009).

Coakley, Dr. Robert W. 1959. Highlights of Mobilization, Korean War. http://www.army.mil/cmh-pg/documents/Korea/kwmob.htm (accessed September 2009).

Programmatic Memorandum of Agreement among the Department of Defense, the Advisory Council on Historic Preservation, and the National Conference of State Historic Preservation Officers (re: demolition of Word War II temporary buildings), signed 1986. http://www.achp.gov/pa6.pdf (accessed September 2009).

"STRAC," 1st Battalion, 22nd Infantry, Fort Lewis, Washington. http://1-22infantry.org/history/pentomic.htm (accessed September 2009). 


\section{Appendix A: NHPA Methodology for Determining Eligibility of Historic Buildings and Levels of District Contribution (1993 Study)}

\section{Criteria for evaluation of significance}

The NRHP Criteria for Evaluation describe how properties and districts are significant for their association with important events or persons (Criterion $\mathrm{A}$ and Criterion $\mathrm{B}$ ), for their importance in design or construction (Criterion C), or for their information potential (Criterion D). The following is a brief description of each of the four NRHP Criteria for Evaluation (excerpted from National Register Bulletin: How to Apply the Nation Register Criteria for Evaluation):

Criterion A: Event - The property is associated with events that have made a significant contribution to the broad patterns of our history.

Criterion B: Person - The property is associated with the lives of persons significant in our past.

Criterion C: Design/Construction - The property embodies the distinctive characteristics of a type, period, or method of construction, or that represent the work of a master, or that possess high artistic values, or that represents a significant and distinguishable entity whose components may lack individual distinction.

Criterion D: Information Potential - The property has yielded, or is likely to yield, information important in prehistory or history. 


\section{Aspects of integrity}

In addition to possessing historical significance, properties must also retain sufficient physical integrity of the features that convey its significance in order to be eligible to the NRHP. ${ }^{411}$

Historic properties either retain integrity (that is, convey their significance) or they do not. Within the concept of integrity, the National Register criteria recognize seven aspects or qualities that, in various combinations, define integrity.

To retain historic integrity a property will always possess several, and usually most, of the aspects. The retention of specific aspects of integrity is paramount for a property to convey its significance. Determining which of these aspects are most important to a particular property requires knowing why, where, and when the property is significant.

Districts and individual resources are considered to be significant if they possess a majority of the following seven aspects of integrity: ${ }^{412}$

1. Location - Location is the place where the historic property was constructed or the place where the historic event occurred.

2. Design - Design is the combination of elements that create the form, plan, space, structure, and style of a property. It results from conscious decisions made during the original conception and planning of a property (or its significant alteration) and applies to activities as diverse as community planning, engineering, architecture, and landscape architecture. Design includes such elements as organization of space, proportion, scale, technology, ornamentation, and materials.

3. Setting - Setting is the physical environment of a historic property. Setting refers to the character of the place in which the property played its historical role. It involves how, not just where, the property is situated and its relationship to surrounding features and open space.

4. Materials - Materials are the physical elements that were combined or deposited during a particular period of time and in a particular pattern or configuration to form a historic property.

\footnotetext{
411 U.S. Department of the Interior, National Park Service, National Register Bulletin: How to Apply the National Register Criteria for Evaluation, (Washington, DC.: GPO, 1997), 44.

412 Ibid., 44-45.
} 
5. Workmanship: the physical evidence of the crafts of a particular culture or people during any given period in history or prehistory.

6. Feeling: a property's expression of the aesthetic or historic sense of a particular time period.

7. Association: the direct link between an important historic event or person and a historic property.

\section{Rating of District Contribution}

Each building determined to be eligible to the Fort Riley Historic District in the 1993 study was given a rating of 1- 5 to denote its contributing value to the district of which it is a part. The rating system conforms to HABS standards which are provided below. 413

Category 1 is the highest category; includes structures of major importance in history, architectural history, industrial history, and history of engineering. For these structures, restoration (or at the very least, a special historic structure maintenance plan) is recommended.

Category 2 includes structures of importance or structures of major importance to which unsympathetic modifications resulting in some loss of integrity may have been made.

Category 3 embraces structures of minor importance, but that contribute to the grouping of which they are a part, or more important structures to which unfortunate modifications of a major nature have been made, resulting in a significant loss of integrity.

Category 4 is for structures of little or no historic importance.

Category 5 is for intrusions.

\footnotetext{
413 John Burns, ed., Recording Historic Structures, (Washington, D.C.: American Institute of Architects Press, 1989), 40-41. This rating system is no longer in use.
} 
These category definitions are purposely general so that they can be tailored to the historical, architectural, industrial, or engineering values established for a particular grouping of structures. 


\section{Appendix B: All Buildings and Structures at Fort Riley Inventoried and Evaluated by ERDC- CERL as of September 2009}

Table 5. Buildings and Structures Determined Eligible to the NRHP.

\begin{tabular}{|c|c|c|c|c|c|c|c|}
\hline $\begin{array}{l}\text { Bldg } \\
\text { No. }\end{array}$ & $\begin{array}{l}\text { Year } \\
\text { Built }\end{array}$ & $\begin{array}{l}\text { Original } \\
\text { Use }\end{array}$ & $\begin{array}{l}\text { Significant } \\
\text { Yes/No }\end{array}$ & Theme & $\begin{array}{l}\text { Integrity } \\
\text { Yes/No }\end{array}$ & $\begin{array}{l}\text { Eligible } \\
\text { Yes/No }\end{array}$ & $\begin{array}{l}\text { NR } \\
\text { Criteria }\end{array}$ \\
\hline 1 & 1888 & Cavalry Post CG OQ & Yes & Cavalry and Artillery & Yes & Yes & $A, C$ \\
\hline $1 G$ & 1935 & Garage & Yes & $1927-1940$ & Yes & Yes & $A, C$ \\
\hline 2 & 1889 & Cavalry Post OQ & Yes & Cavalry and Artillery & Yes & Yes & A, C \\
\hline 3 & 1855 & Post Chapel & Yes & Original Post & Yes & Yes & $\mathrm{A}, \mathrm{C}$ \\
\hline 4 & 1903 & Cavalry Post OQ & Yes & Cavalry and Artillery & Yes & Yes & $A, C$ \\
\hline 5 & 1904 & Cavalry Post OQ & Yes & Cavalry and Artillery & Yes & Yes & A, C \\
\hline 6 & 1897 & Post Chapel & Yes & Cavalry and Artillery & Yes & Yes & $A, C$ \\
\hline 7 & 1887 & Cavalry Post OQ & Yes & Cavalry and Artillery & Yes & Yes & $\mathrm{A}, \mathrm{C}$ \\
\hline 8 & 1887 & Cavalry Post OQ & Yes & Cavalry and Artillery & Yes & Yes & $\mathrm{A}, \mathrm{C}$ \\
\hline 9 & 1890 & Cavalry Post OQ & Yes & Cavalry and Artillery & Yes & Yes & $A, C$ \\
\hline 10 & 1890 & Cavalry Post OQ & Yes & Cavalry and Artillery & Yes & Yes & $A, C$ \\
\hline 11 & 1887 & Cavalry Post OQ & Yes & Cavalry and Artillery & Yes & Yes & $A, C$ \\
\hline 12 & 1887 & Cavalry Post OQ & Yes & Cavalry and Artillery & Yes & Yes & $A, C$ \\
\hline 13 & 1894 & Cavalry Post OQ & Yes & Cavalry and Artillery & Yes & Yes & $A, C$ \\
\hline 14 & 1894 & Cavalry Post OQ & Yes & Cavalry and Artillery & Yes & Yes & $A, C$ \\
\hline 15 & 1889 & Cavalry Post OQ & Yes & Cavalry and Artillery & Yes & Yes & $A, C$ \\
\hline 16 & 1893 & Cavalry Post OQ & Yes & Cavalry and Artillery & Yes & Yes & $A, C$ \\
\hline 17 & 1889 & Cavalry Post OQ & Yes & Cavalry and Artillery & Yes & Yes & $\mathrm{A}, \mathrm{C}$ \\
\hline 18 & 1903 & Cavalry Post OQ & Yes & Cavalry and Artillery & Yes & Yes & $A, C$ \\
\hline 19 & 1890 & Cavalry Post OQ & Yes & Cavalry and Artillery & Yes & Yes & $A, C$ \\
\hline 20 & 1897 & Cavalry Post OQ & Yes & Cavalry and Artillery & Yes & Yes & $A, C$ \\
\hline 21 & 1858 & Calvary Post OQ & Yes & $\begin{array}{l}\text { Original Post/Custer } \\
\text { Quarters }\end{array}$ & Yes & Yes & $A, B, C$ \\
\hline 22 & 1887 & Cavalry Post OQ & Yes & Cavalry and Artillery & Yes & Yes & $\mathrm{A}, \mathrm{C}$ \\
\hline 23 & 1886 & Cavalry Post OQ & Yes & Cavalry and Artillery & Yes & Yes & $A, C$ \\
\hline 24 & 1855 & Cavalry Post OQ & Yes & Original Post & Yes & Yes & $\mathrm{A}, \mathrm{C}$ \\
\hline 25 & 1887 & Cavalry Post OQ & Yes & Cavalry and Artillery & Yes & Yes & $A, C$ \\
\hline 26 & 1889 & Cavalry Post OQ & Yes & Cavalry and Artillery & Yes & Yes & $A, C$ \\
\hline 27 & 1909 & Arnold Hall/BOQ Bks & Yes & Cavalry and Artillery & Yes & Yes & $A, C$ \\
\hline 28 & 1889 & Dispensary & Yes & Cavalry and Artillery & Yes & Yes & $A, C$ \\
\hline 29 & 1941 & Red Cross Bldg & Yes & WW II Build-Up & Yes & Yes & $\mathrm{A}, \mathrm{C}$ \\
\hline 30 & 1940 & Garage & Yes & $1927-1940$ & Yes & Yes & $A, C$ \\
\hline
\end{tabular}




\begin{tabular}{|c|c|c|c|c|c|c|c|}
\hline $\begin{array}{l}\text { Bldg } \\
\text { No. }\end{array}$ & $\begin{array}{l}\text { Year } \\
\text { Built }\end{array}$ & $\begin{array}{l}\text { Original } \\
\text { Use }\end{array}$ & $\begin{array}{l}\text { Significant } \\
\text { Yes/No }\end{array}$ & Theme & $\begin{array}{l}\text { Integrity } \\
\text { Yes/No }\end{array}$ & $\begin{array}{l}\text { Eligible } \\
\text { Yes/No }\end{array}$ & $\begin{array}{l}\text { NR } \\
\text { Criteria }\end{array}$ \\
\hline 31 & 1940 & Garage & Yes & 1927-1940 & Yes & Yes & A, C \\
\hline 40 & 1934 & Student Officers' Apts & Yes & $1927-1940$ & Yes & Yes & A, C \\
\hline 41 & 1934 & Student Officers' Apts & Yes & $1927-1940$ & Yes & Yes & A, C \\
\hline 45 & 1904 & Carr Hall/BOQ Bks & Yes & Cavalry and Artillery & Yes & Yes & A, C \\
\hline 46 & 1940 & Garage & Yes & $1927-1940$ & Yes & Yes & A, C \\
\hline 47 & 1940 & Garage & Yes & $1927-1940$ & Yes & Yes & A, C \\
\hline 48 & 1940 & Garage & Yes & $1927-1940$ & Yes & Yes & A, C \\
\hline 70 & 1934 & Field $\mathrm{OQ}$ & Yes & $1927-1940$ & Yes & Yes & A, C \\
\hline 72 & 1934 & Field $\mathrm{OQ}$ & Yes & $1927-1940$ & Yes & Yes & A, C \\
\hline 74 & 1934 & Field OQ & Yes & $1927-1940$ & Yes & Yes & A, C \\
\hline 76 & 1934 & Field $\mathrm{OQ}$ & Yes & $1927-1940$ & Yes & Yes & A, C \\
\hline 78 & 1934 & Field $\mathrm{OQ}$ & Yes & $1927-1940$ & Yes & Yes & A, C \\
\hline 80 & 1934 & Field OQ & Yes & $1927-1940$ & Yes & Yes & A, C \\
\hline 82 & 1934 & Field $\mathrm{OQ}$ & Yes & $1927-1940$ & Yes & Yes & A, C \\
\hline 85 & 1909 & Arty Post OQ & Yes & Cavalry and Artillery & Yes & Yes & A, C \\
\hline 86 & 1909 & $\mathrm{OQ}$ & Yes & Cavalry and Artillery & Yes & Yes & A, C \\
\hline 87 & 1909 & Arty Post Field OQ & Yes & Cavalry and Artillery & Yes & Yes & A, C \\
\hline 88 & 1897 & Arty Post OQ & Yes & Cavalry and Artillery & Yes & Yes & A, C \\
\hline 89 & 1903 & Arty Post $\mathrm{OQ}$ & Yes & Cavalry and Artillery & Yes & Yes & A, C \\
\hline 90 & 1897 & Arty Post OQ & Yes & Cavalry and Artillery & Yes & Yes & A, C \\
\hline 91 & 1893 & Arty Post OQ & Yes & Cavalry and Artillery & Yes & Yes & A, C \\
\hline 92 & 1889 & Arty Post OQ & Yes & Cavalry and Artillery & Yes & Yes & A, C \\
\hline 93 & 1889 & Arty Post OQ & Yes & Cavalry and Artillery & Yes & Yes & A, C \\
\hline 94 & 1903 & Arty Post OQ & Yes & Cavalry and Artillery & Yes & Yes & A, C \\
\hline 95 & 1903 & Arty Post OQ & Yes & Cavalry and Artillery & Yes & Yes & A, C \\
\hline 96 & 1889 & Arty Post OQ & Yes & Cavalry and Artillery & Yes & Yes & A, C \\
\hline 97 & 1903 & Arty Post OQ & Yes & Cavalry and Artillery & Yes & Yes & A, C \\
\hline 98 & 1904 & Arty Post OQ & Yes & Cavalry and Artillery & Yes & Yes & A, C \\
\hline 99 & 1907 & Arty Post Field OQ & Yes & Cavalry and Artillery & Yes & Yes & A, C \\
\hline 100 & 1887 & Arty Post $\mathrm{OQ}$ & Yes & Cavalry and Artillery & Yes & Yes & A, C \\
\hline 102 & 1940 & Garage & Yes & $1927-1940$ & Yes & Yes & A, C \\
\hline 106 & 1934 & Student Officers' Apts & Yes & $1927-1940$ & Yes & Yes & A, C \\
\hline 108 & 1934 & Student Officers' Apts & Yes & $1927-1940$ & Yes & Yes & A, C \\
\hline 110 & 1910 & $\mathrm{OQ}$ & Yes & Cavalry and Artillery & Yes & Yes & A, C \\
\hline 112 & 1940 & Garage for $110 \& 114$ & Yes & $1927-1940$ & Yes & Yes & A, C \\
\hline 114 & 1910 & $\mathrm{OQ}$ & Yes & Cavalry and Artillery & Yes & Yes & A, C \\
\hline 116 & 1940 & Garage for 118 & Yes & $1927-1940$ & Yes & Yes & A, C \\
\hline 118 & 1934 & Student Officers' Apts & Yes & $1927-1940$ & Yes & Yes & A, C \\
\hline 123 & 1855 & Chaplain's Qtrs & Yes & Original Post & Yes & Yes & A, C \\
\hline 125 & 1939 & Dbl NCO Qtrs & Yes & 1927-1940 & Yes & Yes & A, C \\
\hline
\end{tabular}




\begin{tabular}{|c|c|c|c|c|c|c|c|}
\hline $\begin{array}{l}\text { Bldg } \\
\text { No. }\end{array}$ & $\begin{array}{l}\text { Year } \\
\text { Built }\end{array}$ & $\begin{array}{l}\text { Original } \\
\text { Use }\end{array}$ & $\begin{array}{l}\text { Significant } \\
\text { Yes/No }\end{array}$ & Theme & $\begin{array}{l}\text { Integrity } \\
\text { Yes/No }\end{array}$ & $\begin{array}{l}\text { Eligible } \\
\text { Yes/No }\end{array}$ & $\begin{array}{l}\text { NR } \\
\text { Criteria }\end{array}$ \\
\hline 126 & 1939 & Dbl NCO Qtrs & Yes & $1927-1940$ & Yes & Yes & $A, C$ \\
\hline 127 & 1939 & Garage for 125 & Yes & $1927-1940$ & Yes & Yes & $A, C$ \\
\hline 128 & 1939 & Garage for 126 & Yes & $1927-1940$ & Yes & Yes & $A, C$ \\
\hline 129 & 1939 & Dbl NCO Qtrs & Yes & $1927-1940$ & Yes & Yes & $A, C$ \\
\hline 130 & 1939 & Dbl NCO Qtrs & Yes & $1927-1940$ & Yes & Yes & $A, C$ \\
\hline 131 & 1939 & Garage for 129 & Yes & $1927-1940$ & Yes & Yes & $A, C$ \\
\hline 132 & 1939 & Garage for 130 & Yes & $1927-1940$ & Yes & Yes & $A, C$ \\
\hline 133 & 1939 & Dbl NCO Qtrs & Yes & $1927-1940$ & Yes & Yes & $A, C$ \\
\hline 134 & 1939 & Dbl NCO Qtrs & Yes & $1927-1940$ & Yes & Yes & $A, C$ \\
\hline 135 & 1939 & Garage for 133 & Yes & $1927-1940$ & Yes & Yes & $A, C$ \\
\hline 136 & 1939 & Garage for 134 & Yes & $1927-1940$ & Yes & Yes & $A, C$ \\
\hline 137 & 1939 & Dbl NCO Qtrs & Yes & $1927-1940$ & Yes & Yes & $A, C$ \\
\hline 138 & 1939 & Dbl NCO Qtrs & Yes & $1927-1940$ & Yes & Yes & $A, C$ \\
\hline 139 & 1939 & Garage for 137 & Yes & $1927-1940$ & Yes & Yes & $A, C$ \\
\hline 140 & 1939 & Garage for 138 & Yes & $1927-1940$ & Yes & Yes & $A, C$ \\
\hline 141 & 1939 & Dbl NCO Qtrs & Yes & $1927-1940$ & Yes & Yes & $A, C$ \\
\hline 142 & 1939 & Dbl NCO Qtrs & Yes & $1927-1940$ & Yes & Yes & $A, C$ \\
\hline 143 & 1939 & Garage for 141 & Yes & $1927-1940$ & Yes & Yes & $A, C$ \\
\hline 144 & 1939 & Garage for 142 & Yes & $1927-1940$ & Yes & Yes & $A, C$ \\
\hline 150 & 1910 & Civilians Qtrs & Yes & Cavalry and Artillery & Yes & Yes & $A, C$ \\
\hline 152 & 1903 & NCO Qtrs & Yes & Cavalry and Artillery & Yes & Yes & $A, C$ \\
\hline 153 & 1938 & Dbl NCO Qtrs & Yes & $1927-1940$ & Yes & Yes & $A, C$ \\
\hline 154 & 1940 & Garage & Yes & $1927-1940$ & Yes & Yes & C \\
\hline 155 & 1903 & NCO Qtrs & Yes & Cavalry and Artillery & Yes & Yes & $A, C$ \\
\hline 156 & 1905 & NCO Qtrs & Yes & Cavalry and Artillery & Yes & Yes & $A, C$ \\
\hline 157 & 1931 & Dbl NCO Qtrs & Yes & $1927-1940$ & Yes & Yes & $A, C$ \\
\hline 158 & 1940 & Garage & Yes & $1927-1940$ & Yes & Yes & $A, C$ \\
\hline 159 & 1931 & Dbl NCO Qtrs & Yes & $1927-1940$ & Yes & Yes & $A, C$ \\
\hline 160 & 1931 & Dbl NCO Qtrs & Yes & $1927-1940$ & Yes & Yes & $A, C$ \\
\hline 161 & 1931 & Dbl NCO Qtrs & Yes & $1927-1940$ & Yes & Yes & $A, C$ \\
\hline 162 & 1931 & Dbl NCO Qtrs & Yes & $1927-1940$ & Yes & Yes & $A, C$ \\
\hline 163 & 1940 & Garage & Yes & $1927-1940$ & Yes & Yes & $A, C$ \\
\hline 164 & 1931 & Dbl NCO Qtrs & Yes & $1927-1940$ & Yes & Yes & $A, C$ \\
\hline 165 & 1889 & NCO Qtrs & Yes & Cavalry and Artillery & Yes & Yes & $A, C$ \\
\hline 166 & 1889 & NCO Qtrs & Yes & Cavalry and Artillery & Yes & Yes & $A, C$ \\
\hline 167 & 1889 & NCO Qtrs & Yes & Cavalry and Artillery & Yes & Yes & $A, C$ \\
\hline 170 & 1888 & Sutler's Store/Waters Hall & Yes & Cavalry and Artillery & Yes & Yes & $A, C$ \\
\hline 200 & 1940 & Patton Hall/Academic Bldg & Yes & $1927-1940$ & Yes & Yes & $A, C$ \\
\hline 202 & 1889 & Drill Hall & Yes & Cavalry and Artillery & Yes & Yes & $A, C$ \\
\hline 203 & 1889 & Post Guard House & Yes & Cavalry and Artillery & Yes & Yes & $A, C$ \\
\hline
\end{tabular}




\begin{tabular}{|c|c|c|c|c|c|c|c|}
\hline $\begin{array}{l}\text { Bldg } \\
\text { No. }\end{array}$ & $\begin{array}{l}\text { Year } \\
\text { Built }\end{array}$ & $\begin{array}{l}\text { Original } \\
\text { Use }\end{array}$ & $\begin{array}{l}\text { Significant } \\
\text { Yes/No }\end{array}$ & Theme & $\begin{array}{l}\text { Integrity } \\
\text { Yes/No }\end{array}$ & $\begin{array}{l}\text { Eligible } \\
\text { Yes/No }\end{array}$ & $\begin{array}{l}\text { NR } \\
\text { Criteria }\end{array}$ \\
\hline 205 & 1855 & Post Hosp/Cav Admin Bldg & Yes & Original Post & Yes & Yes & $A, C$ \\
\hline 206 & 1933 & Post Theater & Yes & $1927-1940$ & Yes & Yes & $A, C$ \\
\hline 207 & 1905 & Regimental HQ & Yes & Cavalry and Artillery & Yes & Yes & $A, C$ \\
\hline 208 & 1903 & Cavalry Post Bks & Yes & Cavalry and Artillery & Yes & Yes & $A, C$ \\
\hline 210 & 1889 & Cavalry Post Bks & Yes & Cavalry and Artillery & Yes & Yes & $A, C$ \\
\hline 211 & $\begin{array}{l}1889 \\
1946\end{array}$ & Cavalry Post Bks & Yes & Cavalry and Artillery & Yes & Yes & $A, C$ \\
\hline 212 & 1903 & Cavalry Post Bks & Yes & Cavalry and Artillery & Yes & Yes & $A, C$ \\
\hline 213 & 1889 & Latrine/Motor School & Yes & Cavalry and Artillery & Yes & Yes & $A, C$ \\
\hline 214 & 1903 & Cavalry Post Bks & Yes & Cavalry and Artillery & Yes & Yes & $A, C$ \\
\hline 215 & 1886 & Cavalry Post Bks & Yes & Cavalry and Artillery & Yes & Yes & $A, C$ \\
\hline 216 & 1905 & Guard House & Yes & Cavalry and Artillery & Yes & Yes & $A, C$ \\
\hline 217 & 1887 & Cavalry Post Bks & Yes & Cavalry and Artillery & Yes & Yes & $A, C$ \\
\hline 219 & 1887 & Cavalry Post Bks & Yes & Cavalry and Artillery & Yes & Yes & $A, C$ \\
\hline 221 & 1886 & Cavalry Post Bks & Yes & Cavalry and Artillery & Yes & Yes & $A, C$ \\
\hline 222 & 1907 & School Stable/Bks & Yes & Cavalry and Artillery & Yes & Yes & $A, C$ \\
\hline 223 & 1889 & McGill Hall/Cav Post Bks & Yes & Cavalry and Artillery & Yes & Yes & $A, C$ \\
\hline 224 & 1915 & School Stable/Bks & Yes & Cavalry and Artillery & Yes & Yes & $A, C$ \\
\hline 225 & 1889 & Cavalry Post Latrine & Yes & Cavalry and Artillery & Yes & Yes & $A, C$ \\
\hline 226 & 1905 & Vet Hospital & Yes & Cavalry and Artillery & Yes & Yes & $A, C$ \\
\hline 227 & 1908 & Cooks/Bakers Bks & Yes & Cavalry and Artillery & Yes & Yes & $A, C$ \\
\hline 228 & 1908 & Veterinary Laboratory & Yes & Cavalry and Artillery & Yes & Yes & $A, C$ \\
\hline 229 & 1908 & Drill Hall & Yes & Cavalry and Artillery & Yes & Yes & $A, C$ \\
\hline 236 & 1889 & Street Car Station & Yes & Cavalry and Artillery & Yes & Yes & $A, C$ \\
\hline 240 & 1904 & Farriers Shop & Yes & Cavalry and Artillery & Yes & Yes & $A, C$ \\
\hline 241 & 1904 & $\begin{array}{l}\text { Cavalry Stable Guard } \\
\text { House }\end{array}$ & Yes & Cavalry and Artillery & Yes & Yes & $A, C$ \\
\hline 246 & 1916 & Blacksmith Shop & Yes & Cavalry and Artillery & Yes & Yes & $A, C$ \\
\hline 247 & 1905 & Cavalry Stable & Yes & Cavalry and Artillery & Yes & Yes & $A, C$ \\
\hline 248 & 1938 & Garage & Yes & $1927-1940$ & Yes & Yes & $A, C$ \\
\hline 251 & 1889 & Cavalry Stable & Yes & Cavalry and Artillery & Yes & Yes & $A, C$ \\
\hline 252 & 1905 & Blacksmith Shop & Yes & Cavalry and Artillery & Yes & Yes & $A, C$ \\
\hline 253 & 1903 & Cavalry Stable & Yes & Cavalry and Artillery & Yes & Yes & A, C \\
\hline 255 & 1903 & Cavalry Stable & Yes & Cavalry and Artillery & Yes & Yes & $A, C$ \\
\hline 257 & 1904 & Cavalry Stable & Yes & Cavalry and Artillery & Yes & Yes & $A, C$ \\
\hline 259 & 1904 & $\begin{array}{l}\text { Cavalry Stable Guard } \\
\text { House }\end{array}$ & Yes & Cavalry and Artillery & Yes & Yes & $A, C$ \\
\hline 261 & 1904 & Cavalry Stable & Yes & Cavalry and Artillery & Yes & Yes & $A, C$ \\
\hline 263 & 1904 & Cavalry Stable & Yes & Cavalry and Artillery & Yes & Yes & $A, C$ \\
\hline 265 & 1904 & $\begin{array}{l}\text { Cavalry Stable Guard } \\
\text { House }\end{array}$ & Yes & Cavalry and Artillery & Yes & Yes & $A, C$ \\
\hline
\end{tabular}




\begin{tabular}{|c|c|c|c|c|c|c|c|}
\hline $\begin{array}{l}\text { Bldg } \\
\text { No. }\end{array}$ & $\begin{array}{l}\text { Year } \\
\text { Built }\end{array}$ & $\begin{array}{l}\text { Original } \\
\text { Use }\end{array}$ & $\begin{array}{l}\text { Significant } \\
\text { Yes/No }\end{array}$ & Theme & $\begin{array}{l}\text { Integrity } \\
\text { Yes/No }\end{array}$ & $\begin{array}{l}\text { Eligible } \\
\text { Yes/No }\end{array}$ & $\begin{array}{l}\text { NR } \\
\text { Criteria }\end{array}$ \\
\hline 267 & 1904 & Cavalry Stable & Yes & Cavalry and Artillery & Yes & Yes & $A, C$ \\
\hline 269 & 1889 & Cavalry Stable & Yes & Cavalry and Artillery & Yes & Yes & $\mathrm{A}, \mathrm{C}$ \\
\hline 271 & 1897 & $\begin{array}{l}\text { Cavalry Stable Guard } \\
\text { House }\end{array}$ & Yes & Cavalry and Artillery & Yes & Yes & $A, C$ \\
\hline 273 & 1889 & Cavalry Stable & Yes & Cavalry and Artillery & Yes & Yes & $\mathrm{A}, \mathrm{C}$ \\
\hline 275 & 1897 & $\begin{array}{l}\text { Cavalry Stable Guard } \\
\text { House }\end{array}$ & Yes & Cavalry and Artillery & Yes & Yes & $A, C$ \\
\hline 277 & 1889 & Cavalry Stable & Yes & Cavalry and Artillery & Yes & Yes & $A, C$ \\
\hline 279 & 1897 & $\begin{array}{l}\text { Cavalry Stable Guard } \\
\text { House }\end{array}$ & Yes & Cavalry and Artillery & Yes & Yes & $A, C$ \\
\hline 281 & 1912 & Cavalry Stable & Yes & Cavalry and Artillery & Yes & Yes & $\mathrm{A}, \mathrm{C}$ \\
\hline 283 & 1897 & $\begin{array}{l}\text { Cavalry Stable Guard } \\
\text { House }\end{array}$ & Yes & Cavalry and Artillery & Yes & Yes & $A, C$ \\
\hline 289 & 1905 & Field/Staff/Band Stable & Yes & Cavalry and Artillery & Yes & Yes & $A, C$ \\
\hline 300 & 1890 & Granary & Yes & Cavalry and Artillery & Yes & Yes & $A, C$ \\
\hline 301 & 1892 & QM/Commissary Store & Yes & Cavalry and Artillery & $\begin{array}{l}\text { Yes, but at } \\
\text { risk }\end{array}$ & Yes & $A, C$ \\
\hline 302 & 1908 & QM Storehouse & Yes & Cavalry and Artillery & Yes & Yes & $A, C$ \\
\hline 303 & 1905 & Subsistence Storehouse & Yes & Cavalry and Artillery & $\begin{array}{l}\text { Yes, but at } \\
\text { risk }\end{array}$ & Yes & $A, C$ \\
\hline 304 & 1890 & Coal Shed & Yes & Cavalry and Artillery & $\begin{array}{l}\text { Yes, but at } \\
\text { risk }\end{array}$ & Yes & $A, C$ \\
\hline 305 & 1889 & Heating Plant & Yes & Cavalry and Artillery & Yes & Yes & $\mathrm{A}, \mathrm{C}$ \\
\hline 306 & 1889 & Engineer's Qtrs & Yes & Cavalry and Artillery & Yes & Yes & $A, C$ \\
\hline 307 & 1900 & Ordnance Storehouse & Yes & Cavalry and Artillery & Yes & Yes & $A, C$ \\
\hline 308 & 1904 & Ordnance Storehouse & Yes & Cavalry and Artillery & Yes & Yes & $A, C$ \\
\hline 309 & 1906 & Vegetable Store & Yes & Cavalry and Artillery & Yes & Yes & $A, C$ \\
\hline 310 & 1902 & Bakery & Yes & Cavalry and Artillery & Yes & Yes & $A, C$ \\
\hline 315 & 1935 & Warehouse & Yes & WPA Camp & Yes & Yes & $A, C$ \\
\hline 317 & 1935 & Warehouse & Yes & WPA Camp & Yes & Yes & $A, C$ \\
\hline 319 & 1936 & Instruction Bldg & Yes & WPA Camp & Yes & Yes & $A, C$ \\
\hline 330 & 1936 & Teamsters' Qtrs & Yes & Cavalry and Artillery & Yes & Yes & $A, C$ \\
\hline 332 & 1897 & QM Stable & Yes & Cavalry and Artillery & $\begin{array}{l}\text { Yes, but at } \\
\text { risk }\end{array}$ & Yes & $A, C$ \\
\hline 335 & 1897 & Wagonmaster's Office & Yes & Cavalry and Artillery & Yes & Yes & $A, C$ \\
\hline 337 & 1897 & Teamsters' Mess/Shop & Yes & Cavalry and Artillery & Yes & Yes & $\mathrm{A}, \mathrm{C}$ \\
\hline 350 & 1908 & Granary & Yes & Cavalry and Artillery & Yes & Yes & $A, C$ \\
\hline 352 & 1909 & QM Stable & Yes & Cavalry and Artillery & $\begin{array}{l}\text { Yes, but at } \\
\text { risk }\end{array}$ & Yes & $A, C$ \\
\hline 360 & 1889 & Arty Post Stable & Yes & Cavalry and Artillery & Yes & Yes & $A, C$ \\
\hline 362 & 1889 & Arty Post Stable & Yes & Cavalry and Artillery & Yes & Yes & $A, C$ \\
\hline 363 & 1909 & Arty Gun Shed & Yes & Cavalry and Artillery & Yes & Yes & $A, C$ \\
\hline
\end{tabular}




\begin{tabular}{|c|c|c|c|c|c|c|c|}
\hline $\begin{array}{l}\text { Bldg } \\
\text { No. }\end{array}$ & $\begin{array}{l}\text { Year } \\
\text { Built }\end{array}$ & $\begin{array}{l}\text { Original } \\
\text { Use }\end{array}$ & $\begin{array}{l}\text { Significant } \\
\text { Yes/No }\end{array}$ & Theme & $\begin{array}{l}\text { Integrity } \\
\text { Yes/No }\end{array}$ & $\begin{array}{l}\text { Eligible } \\
\text { Yes/No }\end{array}$ & $\begin{array}{l}\text { NR } \\
\text { Criteria }\end{array}$ \\
\hline 364 & 1889 & Arty Gun Guard & Yes & Cavalry and Artillery & Yes & Yes & $\mathrm{A}, \mathrm{C}$ \\
\hline 366 & 1889 & Arty Post Guard & Yes & Cavalry and Artillery & Yes & Yes & $A, C$ \\
\hline 367 & 1903 & Arty Gun Shed & Yes & Cavalry and Artillery & Yes & Yes & $A, C$ \\
\hline 368 & 1889 & Arty Post Stable & Yes & Cavalry and Artillery & Yes & Yes & $A, C$ \\
\hline 370 & 1904 & Arty Work Shop & Yes & Cavalry and Artillery & Yes & Yes & $A, C$ \\
\hline 372 & 1889 & Arty Post Stable & Yes & Cavalry and Artillery & Yes & Yes & $\mathrm{A}, \mathrm{C}$ \\
\hline 374 & 1904 & Arty Work Shop & Yes & Cavalry and Artillery & Yes & Yes & $A, C$ \\
\hline 375 & 1903 & Arty Gun Shed & Yes & Cavalry and Artillery & Yes & Yes & $A, C$ \\
\hline 376 & 1901 & Arty Post Stable & Yes & Cavalry and Artillery & Yes & Yes & $A, C$ \\
\hline 378 & 1904 & Arty Work Shop & Yes & Cavalry and Artillery & Yes & Yes & $A, C$ \\
\hline 380 & 1903 & Arty Post Stable & Yes & Cavalry and Artillery & Yes & Yes & $\mathrm{A}, \mathrm{C}$ \\
\hline 384 & 1904 & Arty Work Shop & Yes & Cavalry and Artillery & Yes & Yes & $A, C$ \\
\hline 385 & 1904 & Arty Gun Shed & Yes & Cavalry and Artillery & Yes & Yes & $A, C$ \\
\hline 386 & \begin{tabular}{|l}
$1908 /$ \\
1954 \\
\end{tabular} & Arty Post Stable & Yes & Cavalry and Artillery & Yes & Yes & $A, C$ \\
\hline 387 & 1907 & Arty Gun Shed & Yes & Cavalry and Artillery & Yes & Yes & $A, C$ \\
\hline 388 & 1907 & Arty Work Shop & Yes & Cavalry and Artillery & Yes & Yes & $A, C$ \\
\hline 400 & 1907 & Bachelor OQ & Yes & Cavalry and Artillery & Yes & Yes & $A, C$ \\
\hline 401 & 1940 & Garage (1943 addition) & Yes & $1927-1940$ & Yes & Yes & C \\
\hline 402 & 1903 & Gillis Hall/Arty Post Bks & Yes & Cavalry and Artillery & Yes & Yes & $A, C$ \\
\hline 403 & 1889 & Arty Post Admin Bldg & Yes & Cavalry and Artillery & $\begin{array}{l}\text { Yes, but at } \\
\text { risk }\end{array}$ & Yes & $A, C$ \\
\hline 404 & 1902 & Fremont Hall/Arty Post Bks & Yes & Cavalry and Artillery & Yes & Yes & $A, C$ \\
\hline 405 & 1910 & Gym/Arty Post Exchange & Yes & Cavalry and Artillery & Yes & Yes & $A, C$ \\
\hline 406 & 1909 & Arty Bank Bks & Yes & Cavalry and Artillery & Yes & Yes & $A, C$ \\
\hline 407 & 1907 & Arty Post Bks & Yes & Cavalry and Artillery & Yes & Yes & $A, C$ \\
\hline 408 & 1909 & Arty Guard House & Yes & Cavalry and Artillery & Yes & Yes & $A, C$ \\
\hline 409 & 1889 & Gillis Hall/Arty Post Bks & Yes & Cavalry and Artillery & Yes & Yes & $A, C$ \\
\hline 410 & 1897 & Rose Hall/Arty Post Bks & Yes & Cavalry and Artillery & Yes & Yes & $A, C$ \\
\hline 411 & 1889 & Waybur Hall/Arty Post Bks & Yes & Cavalry and Artillery & Yes & Yes & $A, C$ \\
\hline 415 & 1930 & Double NCO Q & Yes & $1927-1940$ & Yes & Yes & $A, C$ \\
\hline 416 & 1930 & Double NCO Q & Yes & 1927-1940 & Yes & Yes & $\mathrm{A}, \mathrm{C}$ \\
\hline 417 & 1930 & Double NCO Q & Yes & $1927-1940$ & Yes & Yes & $A, C$ \\
\hline 418 & 1930 & Double NCO Q & Yes & 1927-1940 & Yes & Yes & $A, C$ \\
\hline 419 & 1930 & Double NCO Q & Yes & $1927-1940$ & Yes & Yes & $A, C$ \\
\hline 420 & 1930 & Double NCO Q & Yes & $1927-1940$ & Yes & Yes & $A, C$ \\
\hline 422 & 1930 & Double NCO Q & Yes & 1927-1940 & Yes & Yes & $A, C$ \\
\hline 423 & 1930 & Double NCO Q & Yes & $1927-1940$ & Yes & Yes & $A, C$ \\
\hline 424 & 1930 & Double NCO Q & Yes & 1927-1940 & Yes & Yes & $A, C$ \\
\hline 425 & 1909 & NCO Qtrs & Yes & Cavalry and Artillery & Yes & Yes & $A, C$ \\
\hline
\end{tabular}




\begin{tabular}{|c|c|c|c|c|c|c|c|}
\hline $\begin{array}{l}\text { Bldg } \\
\text { No. }\end{array}$ & $\begin{array}{l}\text { Year } \\
\text { Built }\end{array}$ & $\begin{array}{l}\text { Original } \\
\text { Use }\end{array}$ & $\begin{array}{l}\text { Significant } \\
\text { Yes/No }\end{array}$ & Theme & $\begin{array}{l}\text { Integrity } \\
\text { Yes/No }\end{array}$ & $\begin{array}{l}\text { Eligible } \\
\text { Yes/No }\end{array}$ & $\begin{array}{l}\text { NR } \\
\text { Criteria }\end{array}$ \\
\hline 426 & 1909 & NCO Qtrs & Yes & Cavalry and Artillery & Yes & Yes & $A, C$ \\
\hline 430 & 1932 & Fire Station & Yes & $1927-1940$ & Yes & Yes & $A, C$ \\
\hline 431 & 1940 & Garage & Yes & $1927-1940$ & Yes & Yes & $A, C$ \\
\hline 432 & 1934 & Student Officers' Apts & Yes & $1927-1940$ & Yes & Yes & $A, C$ \\
\hline 433 & 1934 & Student Officers' Apts & Yes & $1927-1940$ & Yes & Yes & $A, C$ \\
\hline 434 & 1940 & Garage & Yes & $1927-1940$ & Yes & Yes & $A, C$ \\
\hline 435 & 1930 & Student Officers' Apts & Yes & $1927-1940$ & Yes & Yes & $A, C$ \\
\hline 436 & 1930 & Student Officers' Apts & Yes & $1927-1940$ & Yes & Yes & $A, C$ \\
\hline 437 & 1930 & Student Officers' Apts & Yes & $1927-1940$ & Yes & Yes & $A, C$ \\
\hline 438 & 1928 & Student Officers' Apts & Yes & $1927-1940$ & Yes & Yes & $A, C$ \\
\hline 439 & 1928 & Student Officers' Apts & Yes & $1927-1940$ & Yes & Yes & $A, C$ \\
\hline 440 & 1928 & Student Officers' Apts & Yes & $1927-1940$ & Yes & Yes & $A, C$ \\
\hline 441 & 1928 & Student Officers' Apts & Yes & $1927-1940$ & Yes & Yes & $A, C$ \\
\hline 442 & 1940 & Garage & Yes & $1927-1940$ & Yes & Yes & $A, C$ \\
\hline 443 & 1940 & Garage & Yes & $1927-1940$ & Yes & Yes & $A, C$ \\
\hline 444 & 1928 & Student Officers' Apts & Yes & $1927-1940$ & Yes & Yes & $A, C$ \\
\hline 500 & 1889 & $\begin{array}{l}\text { Hospital/Post HQ } \\
\text { (additions) }\end{array}$ & Yes & Cavalry and Artillery & Yes & Yes & $A, C$ \\
\hline 505 & 1909 & Hospital NCO Qtrs & Yes & Cavalry and Artillery & Yes & Yes & $A, C$ \\
\hline 507 & 1891 & Hospital Steward Qtrs & Yes & Cavalry and Artillery & Yes & Yes & $A, C$ \\
\hline 509 & 1910 & Isolation Hospital & Yes & Cavalry and Artillery & Yes & Yes & $\mathrm{A}, \mathrm{C}$ \\
\hline 510 & 1931 & Nurses' Qtrs/Grimes Hall & Yes & $1927-1940$ & Yes & Yes & $A, C$ \\
\hline 520 & 1939 & Dbl NCO Q & Yes & $1927-1940$ & Yes & Yes & $A, C$ \\
\hline 521 & 1940 & Garage & Yes & $1927-1940$ & Yes & Yes & $A, C$ \\
\hline 523 & 1939 & Dbl NCO Q & Yes & $1927-1940$ & Yes & Yes & $A, C$ \\
\hline 524 & 1925 & Civ Fire Chief's Qtrs & Yes & $\begin{array}{l}\text { 1927-1940 } \\
\text { Bungalow }\end{array}$ & Yes & Yes & C \\
\hline 525 & 1930 & Dbl NCO Q & Yes & $1927-1940$ & Yes & Yes & $A, C$ \\
\hline 527 & 1940 & Garage & Yes & $1927-1940$ & Yes & Yes & $\mathrm{A}, \mathrm{C}$ \\
\hline 529 & 1931 & Dbl NCO Q & Yes & $1927-1940$ & Yes & Yes & $A, C$ \\
\hline 531 & 1931 & Dbl NCO Q & Yes & $1927-1940$ & Yes & Yes & $A, C$ \\
\hline 533 & 1940 & Garage & Yes & $1927-1940$ & Yes & Yes & $A, C$ \\
\hline 535 & 1939 & Dbl NCO Q & Yes & $1927-1940$ & Yes & Yes & $A, C$ \\
\hline 550 & 1891 & Magazine & Yes & Cavalry and Artillery & Yes & Yes & $\mathrm{A}, \mathrm{B}, \mathrm{C}$ \\
\hline 720 & 1960 & Flight Simulator & Yes & Army Aviation & Yes & Yes & A \\
\hline 723 & 1959 & Hangar & Yes & Army Aviation & Yes & Yes & $A, C$ \\
\hline 725 & 1960 & Operations Building & Yes & Army Aviation & Yes & Yes & A \\
\hline 741 & 1932 & Marshall Field Hangar & Yes & $1927-1940$ & Yes & Yes & $A, C$ \\
\hline 743 & 1941 & AF Ops Bldg & Yes & WW II Build-Up & Yes & Yes & $\mathrm{A}, \mathrm{C}$ \\
\hline 748 & 1907 & Polo Bungalow & Yes & Cavalry and Artillery & Yes & Yes & $A, C$ \\
\hline
\end{tabular}




\begin{tabular}{|l|l|l|l|l|l|l|l|}
\hline $\begin{array}{l}\text { Bldg } \\
\text { No. }\end{array}$ & $\begin{array}{l}\text { Year } \\
\text { Built }\end{array}$ & $\begin{array}{l}\text { Original } \\
\text { Use }\end{array}$ & $\begin{array}{l}\text { Significant } \\
\text { Yes/No }\end{array}$ & Theme & $\begin{array}{l}\text { Integrity } \\
\text { Yes/No }\end{array}$ & $\begin{array}{l}\text { Eligible } \\
\text { Yes/No }\end{array}$ & $\begin{array}{l}\text { NR } \\
\text { Criteria }\end{array}$ \\
\hline 751 & 1941 & Vehicle Storage Shed & Yes & WWII Build-Up & Yes & Yes & A, C \\
\hline 755 & 1934 & NCO Q & Yes & $1927-1940$ & Yes & Yes & A, C \\
\hline 757 & 1934 & NCO Q & Yes & $1927-1940$ & Yes & Yes & A, C \\
\hline 759 & 1934 & NCO Q & Yes & $1927-1940$ & Yes & Yes & A, C \\
\hline 760 & 1934 & Barracks & Yes & $1927-1940$ & Yes & Yes & A, C \\
\hline 761 & 1934 & NCO Q & Yes & $1927-1940$ & Yes & Yes & A, C \\
\hline 763 & 1934 & NCO Garages & Yes & $1927-1940$ & Yes & Yes & A, C \\
\hline 765 & 1934 & NCO Q & Yes & $1927-1940$ & Yes & Yes & A, C \\
\hline 767 & 1934 & NCO Q & Yes & $1927-1940$ & Yes & Yes & A, C \\
\hline 780 & 1934 & CO OQ & Yes & $1927-1940$ & Yes & Yes & A, C \\
\hline 782 & 1934 & CO OQ & Yes & $1927-1940$ & Yes & Yes & A, C \\
\hline 784 & 1934 & CO OQ & Yes & $1927-1940$ & Yes & Yes & A, C \\
\hline 786 & 1934 & CO OQ & Yes & $1927-1940$ & Yes & Yes & A, C \\
\hline 788 & 1934 & CO OQ & Yes & $1927-1940$ & Yes & Yes & A, C \\
\hline 1020 & 1911 & Quarters for Packers, & Yes & Cavalry and Artillery & Yes & Yes & A, C \\
\hline 1022 & 1914 & Blacksmith Shop & Yes & Cavalry and Artillery & Yes & Yes & A, C \\
\hline$*$
\end{tabular}

* Denotes reconstruction

Table 6. Buildings and Structures Determined Not Eligible to the NRHP.

\begin{tabular}{|c|c|c|c|c|c|}
\hline $\begin{array}{l}\text { Bldg } \\
\text { No. }\end{array}$ & Year Built & Original Use & $\begin{array}{l}\text { Significant } \\
\text { Yes/No }\end{array}$ & Theme & $\begin{array}{l}\text { Integrity } \\
\text { Yes/No }\end{array}$ \\
\hline 180 & 1914 & Dry Cleaning & No & & \\
\hline 181 & 1930 & Dry Cleaning Plant & No & & \\
\hline 182 & 1940 & Flammable Storage & No & & \\
\hline 184 & 1941 & Laundry Boiler House & No & & \\
\hline 198 & 1956 & Water Pump House & No & & \\
\hline 209 & 1936 & $\begin{array}{l}\text { Inflammable Materials } \\
\text { Storehouse }\end{array}$ & No & & \\
\hline 312 & 1930 & Open Warehouse & No & & \\
\hline 314 & 1957 & Hay Shed & No & & \\
\hline 316 & 1929 & Storehouse & No & & \\
\hline 333 & 1948 & $\begin{array}{l}\text { Motor Dispatch/Engineer } \\
\text { Administration }\end{array}$ & No & & \\
\hline 334 & 1897 & QM Garage & No & & \\
\hline 336 & 1897 & Ambulance Shed & No & & \\
\hline 338 & 1904 & Wagon/Lumber Shed & No & & \\
\hline 354 & 1917 & Gas Station & No & & \\
\hline 390 & 1944 & Sewage Treatment Plant & No & & \\
\hline 392 & 1944 & Sewage Treatment Plant & No & & \\
\hline 447 & 1955 & Officers' Club Swimming Pool & No & & \\
\hline
\end{tabular}




\begin{tabular}{|c|c|c|c|c|c|}
\hline $\begin{array}{l}\text { Bldg } \\
\text { No. }\end{array}$ & Year Built & Original Use & $\begin{array}{l}\text { Significant } \\
\text { Yes/No }\end{array}$ & Theme & $\begin{array}{l}\text { Integrity } \\
\text { Yes/No }\end{array}$ \\
\hline 448 & 1949 & Officers' Club Swimming Pool & No & & \\
\hline 449 & 1949 & $\begin{array}{l}\text { Officers' Club Swimming Pool } \\
\text { Filter House }\end{array}$ & No & & \\
\hline 502 & 1959 & Information Booth (MP) & No & & \\
\hline 550 & 1891 & General Storehouse & No & & \\
\hline 600 & 1957 & Hospital & Yes & Army Medicine & No \\
\hline 615 & 1957 & Boiler House, Hospital & Yes & Army Medicine & No \\
\hline 630 & 1917 & Officers Family Housing & No & & \\
\hline 632 & 1931 & Operations General Purpose & No & & \\
\hline 633 & 1931 & Warehouse/Shop & No & & \\
\hline 634 & 1929 & Term Equipment Bldg & No & & \\
\hline 721 & 1957 & Waste Treatment Plant & No & & \\
\hline 727 & 1957 & Hangar & Yes & Army Aviation & No \\
\hline 745 & 1958 & Generator House & No & & \\
\hline 747 & 1960 & Generator House & No & & \\
\hline 754 & 1941 & Storehouse & No & & \\
\hline 928 & 1941 & Small Arms Pyro Magazine & No & & \\
\hline 930 & 1941 & High Explosives Magazine & No & & \\
\hline 931 & 1941 & Small Arms Pyro Magazine & No & & \\
\hline 932 & 1941 & Small Arms Pyro Magazine & No & & \\
\hline 933 & 1941 & Small Arms Pyro Magazine & No & & \\
\hline 934 & 1941 & High Explosives Magazine & No & & \\
\hline 935 & 1941 & Small Arms Pyro Magazine & No & & \\
\hline 936 & 1941 & Small Arms Pyro Magazine & No & & \\
\hline 937 & 1941 & Small Arms Pyro Magazine & No & & \\
\hline 938 & 1929 & Small Arms Pyro Magazine & No & & \\
\hline 939 & 1930 & Small Arms Pyro Magazine & No & & \\
\hline 940 & 1941 & Small Arms Pyro Magazine & No & & \\
\hline 941 & 1927 & Small Arms Pyro Magazine & No & & \\
\hline 1671 & 1941 & Maintenance Shed & No & & \\
\hline 1781 & 1960 & Latrine & No & & \\
\hline 1955 & 1955 & Radioactive Materials Storage & No & & \\
\hline 1980 & 1949 & $\begin{array}{l}\text { Field House /Physical Fitness } \\
\text { Center }\end{array}$ & No & & \\
\hline 2101 & 1952 & Telephone Exchange & No & & \\
\hline 2269 & 1929 & Open Warehouse & No & & \\
\hline 2351 & 1960 & Motor Repair Shop & No & & \\
\hline 2592 & 1941 & Sewage Treatment Plant & No & & \\
\hline 2598 & 1941 & Water Well with Pump Station & No & & \\
\hline 2599 & 1941 & Water Well with Pump Station & No & & \\
\hline
\end{tabular}




\begin{tabular}{|c|c|c|c|c|c|}
\hline $\begin{array}{l}\text { Bldg } \\
\text { No. }\end{array}$ & Year Built & Original Use & $\begin{array}{l}\text { Significant } \\
\text { Yes/No }\end{array}$ & Theme & $\begin{array}{l}\text { Integrity } \\
\text { Yes/No }\end{array}$ \\
\hline 2657 & 1960 & Target House & No & & \\
\hline 3200 & 1958 & Well House \#7 & No & & \\
\hline 3201 & 1958 & Well House \#6 & No & & \\
\hline 3202 & 1937 & Water Well with Pump Station & No & & \\
\hline 3203 & 1952 & Water Well with Pump Station & No & & \\
\hline 3204 & 1943 & Water Well with Pump Station & No & & \\
\hline 3205 & 1929 & Water Well with Pump Station & No & & \\
\hline 3208 & 1929 & $\begin{array}{l}\text { FE Storehouse/Water Control } \\
\text { House }\end{array}$ & No & & \\
\hline 4320 & 1957 & $\begin{array}{l}\text { Gas Pressure Reducing } \\
\text { Station }\end{array}$ & No & & \\
\hline 4604 & 1959 & $\begin{array}{l}\text { Gas Pressure Reducing } \\
\text { Station }\end{array}$ & No & & \\
\hline 5200 & 1960 & Elevated Water Tank & No & & \\
\hline 5201 & 1957 & Water Booster Station & No & & \\
\hline 6420 & 1960 & Telephone Exchange & No & & \\
\hline 6620 & 1963 & $\begin{array}{l}\text { Noncommissioned Officers } \\
\text { Open Mess/ Community } \\
\text { Center }\end{array}$ & No & & \\
\hline 6641 & 1956 & $\begin{array}{l}\text { Gas Pressure Reducing } \\
\text { Station }\end{array}$ & No & & \\
\hline 7024 & 1960 & Physical Fitness Center & No & & \\
\hline 7086 & 1959 & Chapel & No & & \\
\hline 7165 & 1957 & Dispatch Office & Yes & Operation Gyroscope & No \\
\hline 7168 & 1957 & Oil House & Yes & Operation Gyroscope & No \\
\hline 7173 & 1957 & Motor Repair Shop & Yes & Operation Gyroscope & No \\
\hline 7174 & 1957 & Motor Repair Shop & Yes & Operation Gyroscope & No \\
\hline 7175 & 1957 & Motor Repair Shop & Yes & Operation Gyroscope & No \\
\hline 7176 & 1957 & Motor Repair Shop & Yes & Operation Gyroscope & No \\
\hline 7243 & 1960 & Administration \& Storage & Yes & Operation Gyroscope & No \\
\hline 7264 & 1958 & Service Club \#9 & No & & \\
\hline 7285 & 1960 & Theater & No & & \\
\hline 7465 & 1963 & Bath House & No & & \\
\hline 7466 & 1963 & Swimming Pool & No & & \\
\hline 7467 & 1963 & Swimming Pool Pump House & No & & \\
\hline 7515 & 1956 & Elevated Water Tank & No & & \\
\hline 7710 & 1960 & Target House & No & & \\
\hline 8132 & 1956 & FE Storehouse & No & & \\
\hline 8133 & 1956 & $\begin{array}{l}\text { Chlorinator Building/FE } \\
\text { Storehouse }\end{array}$ & No & & \\
\hline 9008 & 1948 & Field Range Latrine & No & & \\
\hline 9081 & 1955 & unknown & No & & \\
\hline
\end{tabular}




\begin{tabular}{|l|l|l|l|l|l|}
\hline $\begin{array}{l}\text { Bldg } \\
\text { No. }\end{array}$ & Year Built & Original Use & $\begin{array}{l}\text { Significant } \\
\text { Yes/No }\end{array}$ & Theme & $\begin{array}{l}\text { Integrity } \\
\text { Yes/No }\end{array}$ \\
\hline 9158 & 1961 & $\begin{array}{l}\text { Storage \& Maintenance } \\
\text { Building (Trainfire) }\end{array}$ & No & & \\
\hline 9165 & 1960 & Target House & No & & \\
\hline 9166 & 1960 & Latrine & No & & \\
\hline 9185 & 1960 & Target House & No & & \\
\hline 9186 & 1960 & Latrine & No & & No \\
\hline 9389 & 1951 & Observation Tower & Yes & $\begin{array}{l}\text { Combat Training and } \\
\text { Army Schools }\end{array}$ & \\
\hline
\end{tabular}




\section{Appendix C: Integrity Review for Properties Declared Eligible in 1993}

This appendix presents tables that show results for the 2008 reassessment of integrity for the Fort Riley thematic groups that make up the historic districts originally identified in 1993.

Table 7. Reassessment of integrity: Original Post Thematic Group.

\begin{tabular}{|r|l|l|l|l|l|l|l|l|}
\hline $\begin{array}{l}\text { Bldg } \\
\text { No. }\end{array}$ & $\begin{array}{l}\text { Year } \\
\text { Built }\end{array}$ & $\begin{array}{l}\text { Original } \\
\text { Use }\end{array}$ & $\begin{array}{l}\text { NR } \\
\text { Criteria }\end{array}$ & Re-roofed & $\begin{array}{l}\text { Window } \\
\text { Mods }\end{array}$ & $\begin{array}{l}\text { Door } \\
\text { Mods }\end{array}$ & $\begin{array}{l}\text { Other } \\
\text { Mods, Adds }\end{array}$ & \begin{tabular}{l} 
Integrity \\
\hline 3
\end{tabular} \\
\hline 1855 & Post Chapel & A, C & X & X & X & X & yes \\
\hline 21 & 1858 & Cavalry Post OQ & A, B, C & X & X & X & X & yes* \\
\hline 24 & 1855 & Cavalry Post OQ & A, C & X & X & X & X & yes \\
\hline 123 & 1855 & Chaplain's Qtrs & A, C & X & X & X & X & yes \\
\hline 205 & 1855 & Post Hosp/Cav Admin Bldg & A, C & X & X & X & X & yes \\
\hline
\end{tabular}

Table 8. Reassessment of integrity: Cavalry and Artillery Thematic Group.

\begin{tabular}{|c|c|c|c|c|c|c|c|c|}
\hline $\begin{array}{l}\text { Bldg } \\
\text { No. }\end{array}$ & $\begin{array}{l}\text { Year } \\
\text { Built }\end{array}$ & Original Use & $\begin{array}{l}\text { NR } \\
\text { Criteria }\end{array}$ & Re-roofed & $\begin{array}{l}\text { Window } \\
\text { Mods }\end{array}$ & $\begin{array}{l}\text { Door } \\
\text { Mods }\end{array}$ & $\begin{array}{l}\text { Other } \\
\text { Mods, Adds }\end{array}$ & Integrity \\
\hline 1 & 1888 & Cavalry Post CG OQ & $A, C$ & $x$ & $x$ & $x$ & $\mathrm{X}$ & yes \\
\hline 2 & 1889 & Cavalry Post OQ & $A, C$ & $x$ & $x$ & $x$ & $x$ & yes \\
\hline 4 & 1903 & Cavalry Post OQ & $A, C$ & $x$ & $x$ & $x$ & $x$ & yes \\
\hline 5 & 1904 & Cavalry Post OQ & $A, C$ & $X$ & $x$ & $x$ & $\mathrm{X}$ & yes \\
\hline 6 & 1897 & Post Chapel & $A, C$ & $x$ & $x$ & $x$ & $x$ & yes \\
\hline 7 & 1887 & Cavalry Post OQ & $A, C$ & $\mathrm{X}$ & $x$ & $x$ & $x$ & yes \\
\hline 8 & 1887 & Cavalry Post OQ & $A, C$ & $\mathrm{X}$ & $x$ & $x$ & $x$ & yes \\
\hline 9 & 1890 & Cavalry Post OQ & $A, C$ & $x$ & $\mathrm{x}$ & $x$ & $x$ & yes \\
\hline 10 & 1890 & Cavalry Post OQ & $A, C$ & $X$ & $x$ & $x$ & $x$ & yes \\
\hline 11 & 1887 & Cavalry Post OQ & $A, C$ & $\mathrm{X}$ & $\mathrm{X}$ & $x$ & $x$ & yes \\
\hline 12 & 1887 & Cavalry Post OQ & $A, C$ & $x$ & $x$ & $x$ & $x$ & yes \\
\hline 13 & 1894 & Cavalry Post OQ & $A, C$ & $x$ & $x$ & $x$ & $x$ & yes \\
\hline 14 & 1894 & Cavalry Post OQ & $A, C$ & $x$ & $x$ & $x$ & $x$ & yes \\
\hline 15 & 1889 & Cavalry Post OQ & $A, C$ & $X$ & $x$ & $x$ & $x$ & yes \\
\hline 16 & 1893 & Cavalry Post OQ & $A, C$ & $X$ & $\mathrm{X}$ & $x$ & $x$ & yes \\
\hline 17 & 1889 & Cavalry Post OQ & $A, C$ & $x$ & $x$ & $x$ & $x$ & yes \\
\hline 18 & 1903 & Cavalry Post OQ & $A, C$ & $x$ & $\mathrm{X}$ & $x$ & $x$ & yes \\
\hline 19 & 1890 & Cavalry Post OQ & $A, C$ & $x$ & $x$ & $x$ & $x$ & yes \\
\hline
\end{tabular}




\begin{tabular}{|c|c|c|c|c|c|c|c|c|}
\hline $\begin{array}{l}\text { Bldg } \\
\text { No. }\end{array}$ & $\begin{array}{l}\text { Year } \\
\text { Built }\end{array}$ & Original Use & $\begin{array}{l}\text { NR } \\
\text { Criteria }\end{array}$ & Re-roofed & $\begin{array}{l}\text { Window } \\
\text { Mods }\end{array}$ & $\begin{array}{l}\text { Door } \\
\text { Mods }\end{array}$ & $\begin{array}{l}\text { Other } \\
\text { Mods, Adds }\end{array}$ & Integrity \\
\hline 20 & 1897 & Cavalry Post OQ & $A, C$ & $x$ & $x$ & $x$ & $x$ & yes \\
\hline 22 & 1887 & Cavalry Post OQ & $A, C$ & $x$ & $x$ & $x$ & $x$ & yes \\
\hline 23 & 1886 & Cavalry Post OQ & $A, C$ & $x$ & $x$ & $x$ & $x$ & yes \\
\hline 25 & 1887 & Cavalry Post OQ & $A, C$ & $x$ & $x$ & $x$ & $x$ & yes \\
\hline 26 & 1889 & Cavalry Post OQ & $A, C$ & $x$ & $x$ & $x$ & $x$ & yes \\
\hline 27 & 1909 & Arnold Hall/BOQ Bks & A, C & $x$ & $x$ & $x$ & $x$ & yes \\
\hline 28 & 1889 & Dispensary & $A, C$ & $x$ & $x$ & $x$ & $x$ & yes \\
\hline 45 & 1904 & Carr Hall/BOQ Bks & $A, C$ & $x$ & $x$ & $x$ & $x$ & yes \\
\hline 85 & 1909 & Arty Post OQ & $A, C$ & $x$ & $x$ & $x$ & $x$ & yes \\
\hline 86 & 1909 & OQ & $A, C$ & $x$ & $x$ & $x$ & $x$ & yes \\
\hline 87 & 1909 & Arty Post Field OQ & $A, C$ & $x$ & $x$ & $x$ & $x$ & yes \\
\hline 88 & 1897 & Arty Post OQ & $A, C$ & $x$ & $x$ & $x$ & $x$ & yes \\
\hline 89 & 1903 & Arty Post OQ & $A, C$ & $x$ & $x$ & $x$ & $x$ & yes \\
\hline 90 & 1897 & Arty Post OQ & $A, C$ & $x$ & $x$ & $x$ & $x$ & yes \\
\hline 91 & 1893 & Arty Post OQ & $A, C$ & $x$ & $x$ & $x$ & $x$ & yes \\
\hline 92 & 1889 & Arty Post OQ & $A, C$ & $x$ & $x$ & $x$ & $x$ & yes \\
\hline 93 & 1889 & Arty Post OQ & $A, C$ & $x$ & $x$ & $x$ & $x$ & yes \\
\hline 94 & 1903 & Arty Post OQ & $A, C$ & $x$ & $x$ & $x$ & $x$ & yes \\
\hline 95 & 1903 & Arty Post OQ & $A, C$ & $x$ & $X$ & $x$ & $x$ & yes \\
\hline 96 & 1889 & Arty Post OQ & $A, C$ & $x$ & $x$ & $x$ & $x$ & yes \\
\hline 97 & 1903 & Arty Post OQ & $A, C$ & $x$ & $x$ & $x$ & $x$ & yes \\
\hline 98 & 1904 & Arty Post OQ & $A, C$ & $x$ & $x$ & $x$ & $x$ & yes \\
\hline 99 & 1907 & Arty Post Field OQ & $A, C$ & $x$ & $x$ & $x$ & $x$ & yes \\
\hline 100 & 1887 & Arty Post OQ & $A, C$ & $x$ & $X$ & $x$ & $x$ & yes \\
\hline 110 & 1910 & OQ & A, C & $x$ & $x$ & - & $x$ & yes \\
\hline 114 & 1910 & OQ & A, C & $x$ & $x$ & - & $x$ & yes \\
\hline 150 & 1910 & Civilians Qtrs & $A, C$ & $x$ & $x$ & $x$ & $x$ & yes \\
\hline 152 & 1903 & NCO Qtrs & $A, C$ & $x$ & $x$ & $x$ & - & yes \\
\hline 155 & 1903 & NCO Qtrs & A, C & $x$ & $x$ & $x$ & - & yes \\
\hline 156 & 1905 & NCO Qtrs & $A, C$ & $x$ & $x$ & $x$ & - & yes \\
\hline 165 & 1889 & NCO Qtrs & $A, C$ & $x$ & $x$ & $x$ & - & yes \\
\hline 166 & 1889 & NCO Qtrs & $A, C$ & $x$ & $x$ & $x$ & - & yes \\
\hline 167 & 1889 & NCO Qtrs & $A, C$ & $x$ & $x$ & $x$ & - & yes \\
\hline 170 & 1888 & Sutler's Store/Waters Hall & A, C & $x$ & $x$ & $x$ & $x$ & yes \\
\hline 202 & 1889 & Drill Hall & A, C & $x$ & $x$ & $x$ & $x$ & yes \\
\hline 203 & 1889 & Post Guard House & A, C & $x$ & $x$ & $x$ & $x$ & yes \\
\hline 207 & 1905 & Regimental HQ & $A, C$ & $x$ & $x$ & - & $x$ & yes \\
\hline 208 & 1903 & Cavalry Post Bks & $A, C$ & $x$ & $x$ & $x$ & $x$ & yes \\
\hline 210 & 1889 & Cavalry Post Bks & $A, C$ & $x$ & $x$ & $x$ & $x$ & yes \\
\hline
\end{tabular}




\begin{tabular}{|c|c|c|c|c|c|c|c|c|}
\hline $\begin{array}{l}\text { Bldg } \\
\text { No. }\end{array}$ & $\begin{array}{l}\text { Year } \\
\text { Built }\end{array}$ & Original Use & \begin{tabular}{|l|} 
NR \\
Criteria
\end{tabular} & Re-roofed & $\begin{array}{l}\text { Window } \\
\text { Mods }\end{array}$ & $\begin{array}{l}\text { Door } \\
\text { Mods }\end{array}$ & $\begin{array}{l}\text { Other } \\
\text { Mods, Adds }\end{array}$ & Integrity \\
\hline 211 & $\begin{array}{l}1889 / 1 \\
946\end{array}$ & Cavalry Post Bks & $A, C$ & $x$ & $x$ & unknown & - & $\begin{array}{l}\text { yes, but at } \\
\text { risk }\end{array}$ \\
\hline 212 & 1903 & Cavalry Post Bks & A, C & $x$ & $\mathrm{x}$ & $\mathrm{x}$ & $\mathrm{x}$ & yes \\
\hline 213 & 1889 & Latrine/Motor School & A, C & $x$ & $x$ & $x$ & - & yes \\
\hline 214 & 1903 & Cavalry Post Bks & A, C & $x$ & $x$ & $x$ & $x$ & yes \\
\hline 215 & 1886 & Cavalry Post Bks & A, C & $x$ & $x$ & $x$ & $x$ & yes \\
\hline 216 & 1905 & Guard House & A, C & $x$ & $x$ & $x$ & $x$ & yes \\
\hline 217 & 1887 & Cavalry Post Bks & A, C & $x$ & $x$ & $x$ & $x$ & yes \\
\hline 219 & 1887 & Cavalry Post Bks & A, C & $x$ & $x$ & $x$ & $x$ & yes \\
\hline 221 & 1886 & Cavalry Post Bks & $A, C$ & $x$ & $x$ & $x$ & $x$ & yes \\
\hline 222 & 1907 & School Stable/Bks & A, C & $x$ & $x$ & $x$ & $x$ & yes \\
\hline 223 & 1889 & $\begin{array}{l}\text { McGill Hall/Cavalry Post } \\
\text { Bks }\end{array}$ & A, C & $x$ & $x$ & $x$ & $x$ & yes \\
\hline 224 & 1915 & School Stable/Bks & A, C & $x$ & $x$ & $x$ & $x$ & yes \\
\hline 225 & 1889 & Cavalry Post Latrine & A, C & $x$ & - & $x$ & $x$ & yes \\
\hline 226 & 1905 & Vet Hospital & A, C & $x$ & $x$ & $x$ & $x$ & yes \\
\hline 227 & 1908 & Cooks/Bakers Bks & A, C & $x$ & $x$ & $x$ & $x$ & yes \\
\hline 228 & 1908 & Veterinary Laboratory & A, C & $x$ & $x$ & $x$ & $x$ & yes \\
\hline 229 & 1908 & Drill Hall & A, C & $x$ & $x$ & $x$ & $x$ & yes \\
\hline 236 & 1889 & Street Car Station & A, C & $x$ & - & - & - & yes \\
\hline 240 & 1904 & Farriers Shop & A, C & $x$ & $x$ & $x$ & $x$ & yes \\
\hline 241 & 1904 & $\begin{array}{l}\text { Cavalry Stable Guard } \\
\text { House }\end{array}$ & A, C & $x$ & $x$ & $x$ & - & yes \\
\hline 246 & 1916 & Blacksmith Shop & $A, C$ & $x$ & $x$ & - & $x$ & yes \\
\hline 247 & 1905 & Cavalry Stable & $\mathrm{A}, \mathrm{C}$ & $x$ & $x$ & $x$ & $x$ & yes \\
\hline 251 & 1889 & Cavalry Stable & A, C & $x$ & $x$ & $x$ & $x$ & yes \\
\hline 252 & 1905 & $\begin{array}{l}\text { Blacksmith/Carpentry } \\
\text { Shop }\end{array}$ & A, C & $x$ & $x$ & $x$ & - & yes \\
\hline 253 & 1903 & Cavalry Stable & A, C & $x$ & $x$ & $x$ & $x$ & yes \\
\hline 255 & 1903 & Cavalry Stable & A, C & $x$ & $x$ & $x$ & - & yes \\
\hline 257 & 1904 & Cavalry Stable & A, C & $x$ & $x$ & $x$ & $x$ & yes \\
\hline 259 & 1904 & $\begin{array}{l}\text { Cavalry Stable Guard } \\
\text { House }\end{array}$ & A, C & $x$ & $x$ & $x$ & - & yes \\
\hline 261 & 1904 & Cavalry Stable & A, C & $x$ & $x$ & $x$ & $x$ & yes \\
\hline 263 & 1904 & Cavalry Stable & A, C & $x$ & $x$ & $x$ & $x$ & yes \\
\hline 265 & 1904 & $\begin{array}{l}\text { Cavalry Stable Guard } \\
\text { House }\end{array}$ & A, C & $x$ & - & $x$ & - & yes \\
\hline 267 & 1904 & Cavalry Stable & A, C & $x$ & $x$ & $x$ & $x$ & yes \\
\hline 269 & 1889 & Cavalry Stable & A, C & $x$ & $x$ & $x$ & $x$ & yes \\
\hline 271 & 1897 & $\begin{array}{l}\text { Cavalry Stable Guard } \\
\text { House }\end{array}$ & A, C & $x$ & - & $x$ & - & yes \\
\hline 273 & 1889 & Cavalry Stable & A, C & $\mathrm{x}$ & $x$ & $x$ & - & yes \\
\hline
\end{tabular}




\begin{tabular}{|c|c|c|c|c|c|c|c|c|}
\hline $\begin{array}{l}\text { Bldg } \\
\text { No. }\end{array}$ & $\begin{array}{l}\text { Year } \\
\text { Built }\end{array}$ & Original Use & $\begin{array}{l}\text { NR } \\
\text { Criteria }\end{array}$ & Re-roofed & $\begin{array}{l}\text { Window } \\
\text { Mods }\end{array}$ & $\begin{array}{l}\text { Door } \\
\text { Mods }\end{array}$ & $\begin{array}{l}\text { Other } \\
\text { Mods, Adds }\end{array}$ & Integrity \\
\hline 275 & 1897 & $\begin{array}{l}\text { Cavalry Stable Guard } \\
\text { House }\end{array}$ & $A, C$ & $x$ & $x$ & $x$ & $x$ & yes \\
\hline 277 & 1889 & Cavalry Stable & $A, C$ & $x$ & $x$ & $x$ & - & yes \\
\hline 279 & 1897 & $\begin{array}{l}\text { Cavalry Stable Guard } \\
\text { House }\end{array}$ & $A, C$ & $x$ & $x$ & $x$ & - & yes \\
\hline 281 & 1912 & Cavalry Stable & $A, C$ & $x$ & $x$ & $x$ & $x$ & yes \\
\hline 283 & 1897 & $\begin{array}{l}\text { Cavalry Stable Guard } \\
\text { House }\end{array}$ & $A, C$ & $x$ & - & $x$ & $x$ & yes \\
\hline 289 & 1905 & Field/Staff/Band Stable & $A, C$ & $x$ & $x$ & $x$ & $x$ & yes \\
\hline 300 & 1890 & Granary & $A, C$ & $x$ & - & $x$ & $x$ & yes \\
\hline 301 & 1892 & QM/Commissary Store & $A, C$ & $x$ & $x$ & $x$ & $x$ & $\begin{array}{l}\text { yes, but at } \\
\text { risk }\end{array}$ \\
\hline 302 & 1908 & QM Storehouse & $A, C$ & $x$ & $x$ & $x$ & $x$ & yes \\
\hline 303 & 1905 & Subsistence Storehouse & $A, C$ & $x$ & $x$ & $x$ & $x$ & $\begin{array}{l}\text { yes, but at } \\
\text { risk }\end{array}$ \\
\hline 304 & 1890 & Coal Shed & $A, C$ & $x$ & $x$ & $x$ & $x$ & $\begin{array}{l}\text { yes, but at } \\
\text { risk }\end{array}$ \\
\hline 305 & 1889 & Heating Plant & $A, C$ & $x$ & $x$ & $x$ & $x$ & yes \\
\hline 306 & 1889 & Engineer's Qtrs & $A, C$ & $x$ & - & - & $x$ & yes \\
\hline 307 & 1900 & Ordnance Storehouse & $A, C$ & $x$ & - & $x$ & $x$ & yes \\
\hline 308 & 1904 & Ordnance Storehouse & $A, C$ & $x$ & - & $x$ & $x$ & yes \\
\hline 309 & 1906 & Vegetable Store & $A, C$ & $x$ & - & - & $x$ & yes \\
\hline 310 & 1902 & Bakery & $A, C$ & $x$ & - & $x$ & $x$ & yes \\
\hline 330 & 1936 & Teamsters' Qtrs & $A, C$ & $x$ & - & - & $x$ & yes \\
\hline 332 & 1897 & QM Stable & $A, C$ & $x$ & - & $x$ & $x$ & $\begin{array}{l}\text { yes, but at } \\
\text { risk }\end{array}$ \\
\hline 335 & 1897 & Wagonmaster's Office & $A, C$ & $x$ & - & - & $x$ & yes \\
\hline 337 & 1897 & Teamsters' Mess/Shop & $A, C$ & $x$ & $x$ & $x$ & $x$ & yes \\
\hline 350 & 1908 & Granary & $A, C$ & $x$ & - & $x$ & $x$ & yes \\
\hline 352 & 1909 & QM Stable & $A, C$ & $\mathrm{x}$ & $X$ & $x$ & $x$ & $\begin{array}{l}\text { yes, but at } \\
\text { risk }\end{array}$ \\
\hline 360 & 1889 & Arty Post Stable & $A, C$ & $x$ & $x$ & $x$ & - & yes \\
\hline 362 & 1889 & Arty Post Stable & $A, C$ & $x$ & $x$ & $x$ & - & yes \\
\hline 363 & 1909 & Arty Gun Shed & $A, C$ & $x$ & $x$ & $x$ & - & yes \\
\hline 364 & 1889 & Arty Gun Guard & $A, C$ & $x$ & $x$ & $x$ & - & yes \\
\hline 366 & 1889 & Arty Post Guard & $A, C$ & $x$ & $x$ & $x$ & - & yes \\
\hline 367 & 1903 & Arty Gun Shed & $A, C$ & $x$ & $x$ & $x$ & - & yes \\
\hline 368 & 1889 & Arty Post Stable & $A, C$ & $x$ & $x$ & $x$ & $x$ & yes \\
\hline 370 & 1904 & Arty Work Shop & $A, C$ & $x$ & $x$ & $x$ & $x$ & yes \\
\hline 372 & 1889 & Arty Post Stable & $A, C$ & $x$ & $x$ & $x$ & $x$ & yes \\
\hline 374 & 1904 & Arty Work Shop & $A, C$ & $x$ & $x$ & $x$ & $x$ & yes \\
\hline 375 & 1903 & Arty Gun Shed & $A, C$ & $x$ & $x$ & $x$ & - & yes \\
\hline
\end{tabular}




\begin{tabular}{|c|c|c|c|c|c|c|c|c|}
\hline $\begin{array}{l}\text { Bldg } \\
\text { No. }\end{array}$ & $\begin{array}{l}\text { Year } \\
\text { Built }\end{array}$ & Original Use & $\begin{array}{l}\text { NR } \\
\text { Criteria }\end{array}$ & Re-roofed & $\begin{array}{l}\text { Window } \\
\text { Mods }\end{array}$ & $\begin{array}{l}\text { Door } \\
\text { Mods }\end{array}$ & $\begin{array}{l}\text { Other } \\
\text { Mods, Adds }\end{array}$ & Integrity \\
\hline 376 & 1901 & Arty Post Stable & $A, C$ & $x$ & $\mathrm{x}$ & $x$ & - & yes \\
\hline 378 & 1904 & Arty Work Shop & $A, C$ & $x$ & $x$ & $x$ & - & yes \\
\hline 380 & 1903 & Arty Post Stable & $A, C$ & $x$ & $x$ & $x$ & $x$ & yes \\
\hline 384 & 1904 & Arty Work Shop & $A, C$ & $X$ & $\mathrm{X}$ & $x$ & - & yes \\
\hline 385 & 1904 & Arty Gun Shed & $A, C$ & $x$ & $\mathrm{X}$ & $x$ & - & yes \\
\hline 386 & 1908 & Arty Post Stable & $A, C$ & $x$ & $\mathrm{X}$ & $x$ & - & yes \\
\hline 387 & 1907 & Arty Gun Shed & $A, C$ & $x$ & $\mathrm{X}$ & $x$ & $x$ & yes \\
\hline 388 & 1907 & Arty Work Shop & $A, C$ & $x$ & $x$ & $x$ & $x$ & yes \\
\hline 400 & 1907 & Bachelor OQ & $A, C$ & $x$ & $\mathrm{X}$ & $x$ & $x$ & yes \\
\hline 402 & 1903 & Gillis Hall/Arty Post Bks & $A, C$ & $x$ & $\mathrm{x}$ & $x$ & $x$ & yes \\
\hline 403 & 1889 & Arty Post Admin Bldg & $A, C$ & $x$ & $x$ & $x$ & $x$ & $\begin{array}{l}\text { yes, but at } \\
\text { risk }\end{array}$ \\
\hline 404 & 1902 & Fremont Hall/Arty post Bks & $A, C$ & $X$ & $X$ & $\mathrm{X}$ & $x$ & yes \\
\hline 405 & 1910 & Gym/Arty Post Exchange & $A, C$ & $x$ & $x$ & $x$ & $x$ & yes \\
\hline 406 & 1909 & Arty Bank Bks & $A, C$ & $x$ & $x$ & $x$ & $x$ & yes \\
\hline 407 & 1907 & Arty Post Bks & $A, C$ & $x$ & $x$ & $x$ & $x$ & yes \\
\hline 408 & 1909 & Arty Guard House & $A, C$ & $x$ & $x$ & $x$ & $x$ & yes \\
\hline 409 & 1889 & Gillis Hall/Arty Post Bks & $A, C$ & $x$ & $x$ & $x$ & $x$ & yes \\
\hline 410 & 1897 & Rose Hall/Arty Post Bks & $A, C$ & $x$ & $x$ & $x$ & $x$ & yes \\
\hline 411 & 1889 & Waybur Hall/Arty Post Bks & $A, C$ & $x$ & $x$ & $x$ & $x$ & yes \\
\hline 425 & 1909 & NCO Qtrs & A, C & $x$ & $x$ & $x$ & $x$ & yes \\
\hline 426 & 1909 & NCO Qtrs & $A, C$ & $x$ & $x$ & $x$ & $x$ & yes \\
\hline 500 & 1889 & $\begin{array}{l}\text { Hospital/Post HQ } \\
\text { (additions) }\end{array}$ & $A, C$ & $x$ & $x$ & $x$ & $x$ & yes \\
\hline 505 & 1909 & Hospital NCO Qtrs & $A, C$ & $x$ & - & - & $x$ & yes \\
\hline 507 & 1891 & Hospital Steward Qtrs & $A, C$ & $x$ & - & - & - & yes \\
\hline 509 & 1910 & Isolation Hospital & $A, C$ & $x$ & - & $x$ & $x$ & yes \\
\hline 550 & 1891 & Magazine & $A, B, C$ & - & - & - & - & yes \\
\hline 748 & 1907 & Polo Bungalow & $A, C$ & $x$ & $x$ & $x$ & - & yes \\
\hline 1020 & 1911 & $\begin{array}{l}\text { Quarters for Packers, } \\
\text { Muleskinners, and Farriers }\end{array}$ & $A, C$ & $x$ & $x$ & $x$ & $x$ & yes \\
\hline 1022 & 1914 & Blacksmith Shop & $A, C$ & $x$ & $x$ & $x$ & $x$ & yes \\
\hline
\end{tabular}

* Denotes reconstruction

Table 9. Reassessment of integrity of the 1927-1940 Thematic Group.

\begin{tabular}{|c|l|l|l|c|l|c|l|l|}
\hline $\begin{array}{l}\text { Bldg } \\
\text { No. }\end{array}$ & $\begin{array}{l}\text { Year } \\
\text { Built }\end{array}$ & Original Use & $\begin{array}{l}\text { NR } \\
\text { Criteria }\end{array}$ & Re-roofed & $\begin{array}{l}\text { Window } \\
\text { Mods }\end{array}$ & $\begin{array}{l}\text { Door } \\
\text { Mods }\end{array}$ & $\begin{array}{l}\text { Other Mods, } \\
\text { Adds }\end{array}$ & Integrity \\
\hline $1 G$ & 1935 & Garage & A, C & X & - & $X$ & - & yes \\
\hline 30 & 1940 & Garage & A, C & X & - & - & X & yes \\
\hline 31 & 1940 & Garage & A, C & X & - & $X$ & X & yes \\
\hline
\end{tabular}




\begin{tabular}{|c|c|c|c|c|c|c|c|c|}
\hline $\begin{array}{l}\text { Bldg } \\
\text { No. }\end{array}$ & $\begin{array}{l}\text { Year } \\
\text { Built }\end{array}$ & Original Use & $\begin{array}{l}\text { NR } \\
\text { Criteria }\end{array}$ & Re-roofed & $\begin{array}{l}\text { Window } \\
\text { Mods }\end{array}$ & $\begin{array}{l}\text { Door } \\
\text { Mods }\end{array}$ & $\begin{array}{l}\text { Other Mods, } \\
\text { Adds }\end{array}$ & Integrity \\
\hline 40 & 1934 & Student Officers' Apts & $A, C$ & $x$ & $x$ & $x$ & - & yes \\
\hline 41 & 1934 & Student Officers' Apts & $\mathrm{A}, \mathrm{C}$ & $x$ & $x$ & $x$ & - & yes \\
\hline 46 & 1940 & Garage & $A, C$ & $x$ & - & - & $x$ & yes \\
\hline 47 & 1940 & Garage & $A, C$ & $x$ & - & - & $x$ & yes \\
\hline 48 & 1940 & Garage & $A, C$ & $x$ & - & $x$ & $x$ & yes \\
\hline 70 & 1934 & Field OQ & $\mathrm{A}, \mathrm{C}$ & $x$ & $x$ & $x$ & - & yes \\
\hline 72 & 1934 & Field OQ & $\mathrm{A}, \mathrm{C}$ & $x$ & $x$ & $x$ & - & yes \\
\hline 74 & 1934 & Field OQ & $A, C$ & $x$ & $x$ & $x$ & - & yes \\
\hline 76 & 1934 & Field OQ & $A, C$ & $x$ & $x$ & $x$ & - & yes \\
\hline 78 & 1934 & Field OQ & $A, C$ & $\mathrm{X}$ & $x$ & $\mathrm{X}$ & - & yes \\
\hline 80 & 1934 & Field OQ & $A, C$ & $x$ & $x$ & $x$ & - & yes \\
\hline 82 & 1934 & Field OQ & $A, C$ & $x$ & $x$ & $x$ & - & yes \\
\hline 102 & 1940 & Garage & $A, C$ & $\mathrm{X}$ & - & $\mathrm{X}$ & - & yes \\
\hline 106 & 1934 & Student Officers' Apts & $A, C$ & $x$ & $x$ & $x$ & - & yes \\
\hline 108 & 1934 & Student Officers' Apts & $\mathrm{A}, \mathrm{C}$ & $x$ & $x$ & $x$ & - & yes \\
\hline 112 & 1940 & Garage for $110 \& 114$ & $\mathrm{~A}, \mathrm{C}$ & $x$ & - & $x$ & - & yes \\
\hline 116 & 1940 & Garage for 118 & $A, C$ & $x$ & - & $x$ & - & yes \\
\hline 118 & 1934 & Student Officers' Apts & $A, C$ & $x$ & $x$ & $x$ & - & yes \\
\hline 125 & 1939 & Dbl NCO Qtrs & $A, C$ & $x$ & $x$ & $\mathrm{X}$ & $x$ & yes \\
\hline 126 & 1939 & Dbl NCO Qtrs & $A, C$ & $x$ & $X$ & $\mathrm{X}$ & $x$ & yes \\
\hline 127 & 1939 & Garage for 125 & $A, C$ & - & - & $x$ & - & yes \\
\hline 128 & 1939 & Garage for 126 & $\mathrm{~A}, \mathrm{C}$ & - & - & $x$ & - & yes \\
\hline 129 & 1939 & Dbl NCO Qtrs & $A, C$ & $x$ & $x$ & $\mathrm{X}$ & $x$ & yes \\
\hline 130 & 1939 & Dbl NCO Qtrs & $A, C$ & $x$ & $x$ & $x$ & $x$ & yes \\
\hline 131 & 1939 & Garage for 129 & $\mathrm{~A}, \mathrm{C}$ & - & - & $x$ & - & yes \\
\hline 132 & 1939 & Garage for 130 & $\mathrm{~A}, \mathrm{C}$ & - & - & $x$ & - & yes \\
\hline 133 & 1939 & Dbl NCO Qtrs & $A, C$ & $\mathrm{X}$ & $X$ & $\mathrm{X}$ & $X$ & yes \\
\hline 134 & 1939 & Dbl NCO Qtrs & $A, C$ & $x$ & $x$ & $x$ & $x$ & yes \\
\hline 135 & 1939 & Garage for 133 & $A, C$ & - & - & $x$ & - & yes \\
\hline 136 & 1939 & Garage for 134 & $A, C$ & - & - & $\mathrm{X}$ & - & yes \\
\hline 137 & 1939 & Dbl NCO Qtrs & $A, C$ & $x$ & $x$ & $x$ & $x$ & yes \\
\hline 138 & 1939 & Dbl NCO Qtrs & $A, C$ & $x$ & $x$ & $x$ & $x$ & yes \\
\hline 139 & 1939 & Garage for 137 & $A, C$ & - & - & $x$ & - & yes \\
\hline
\end{tabular}




\begin{tabular}{|c|c|c|c|c|c|c|c|c|}
\hline $\begin{array}{l}\text { Bldg } \\
\text { No. }\end{array}$ & $\begin{array}{l}\text { Year } \\
\text { Built }\end{array}$ & Original Use & $\begin{array}{l}\text { NR } \\
\text { Criteria }\end{array}$ & Re-roofed & $\begin{array}{l}\text { Window } \\
\text { Mods }\end{array}$ & $\begin{array}{l}\text { Door } \\
\text { Mods }\end{array}$ & $\begin{array}{l}\text { Other Mods, } \\
\text { Adds }\end{array}$ & Integrity \\
\hline 140 & 1939 & Garage for 138 & $A, C$ & - & - & $x$ & - & yes \\
\hline 141 & 1939 & Dbl NCO Qtrs & $A, C$ & $x$ & $x$ & $x$ & $x$ & yes \\
\hline 142 & 1939 & Dbl NCO Qtrs & $A, C$ & $x$ & $x$ & $x$ & $x$ & yes \\
\hline 143 & 1939 & Garage for 141 & $A, C$ & - & - & $x$ & - & yes \\
\hline 144 & 1939 & Garage for 142 & $A, C$ & - & - & $x$ & - & yes \\
\hline 153 & 1938 & Dbl NCO Qtrs & $A, C$ & $x$ & $x$ & $x$ & - & yes \\
\hline 154 & 1940 & Garage & C & $x$ & - & $x$ & - & yes \\
\hline 157 & 1931 & Dbl NCO Qtrs & $A, C$ & $x$ & $x$ & $x$ & - & yes \\
\hline 158 & 1940 & Garage & $A, C$ & $x$ & - & $x$ & - & yes \\
\hline 159 & 1931 & Dbl NCO Qtrs & $A, C$ & $x$ & $x$ & $x$ & - & yes \\
\hline 160 & 1931 & Dbl NCO Qtrs & $A, C$ & $x$ & $x$ & $x$ & - & yes \\
\hline 161 & 1931 & Dbl NCO Qtrs & $A, C$ & $x$ & $x$ & $\mathrm{X}$ & - & yes \\
\hline 162 & 1931 & Dbl NCO Qtrs & $A, C$ & $x$ & $x$ & $x$ & - & yes \\
\hline 163 & 1940 & Garage & $A, C$ & $x$ & - & $x$ & - & yes \\
\hline 164 & 1931 & Dbl NCO Qtrs & $A, C$ & $x$ & $\mathrm{x}$ & $\mathrm{X}$ & - & yes \\
\hline 200 & 1940 & Patton Hall/Academic Bldg & $A, C$ & $x$ & $x$ & $\mathrm{x}$ & $x$ & yes \\
\hline 206 & 1933 & Post Theater & $A, C$ & $x$ & $x$ & $\mathrm{X}$ & $x$ & yes \\
\hline 248 & 1938 & Garage & $A, C$ & $x$ & $x$ & $\mathrm{X}$ & - & yes \\
\hline 401 & 1940 & Garage (1943 addition) & C & $x$ & - & $x$ & - & yes \\
\hline 415 & 1930 & Double NCO Q & $A, C$ & $x$ & $x$ & $x$ & - & yes \\
\hline 416 & 1930 & Double NCO Q & $A, C$ & $x$ & $x$ & $x$ & - & yes \\
\hline 417 & 1930 & Double NCO Q & $A, C$ & $x$ & $x$ & $x$ & - & yes \\
\hline 418 & 1930 & Double NCO Q & $A, C$ & $x$ & $x$ & $x$ & - & yes \\
\hline 419 & 1930 & Double NCO Q & $A, C$ & $x$ & $x$ & $\mathrm{X}$ & - & yes \\
\hline 420 & 1930 & Double NCO Q & $A, C$ & $x$ & $x$ & $\mathrm{X}$ & - & yes \\
\hline 422 & 1930 & Double NCO Q & $A, C$ & $x$ & $x$ & $x$ & - & yes \\
\hline 423 & 1930 & Double NCO Q & $A, C$ & $x$ & $x$ & $x$ & - & yes \\
\hline 424 & 1930 & Double NCO Q & $A, C$ & $x$ & $x$ & $x$ & - & yes \\
\hline 430 & 1932 & Fire Station & $A, C$ & $x$ & $x$ & $x$ & $x$ & yes \\
\hline 431 & 1940 & Garage & $A, C$ & $x$ & - & $x$ & - & yes \\
\hline 432 & 1934 & Student Officers' Apts & $A, C$ & $x$ & $x$ & $x$ & - & yes \\
\hline 433 & 1934 & Student Officers' Apts & $A, C$ & $x$ & $x$ & $x$ & - & yes \\
\hline 434 & 1940 & Garage & $A, C$ & $x$ & - & $x$ & - & yes \\
\hline
\end{tabular}




\begin{tabular}{|c|c|c|c|c|c|c|c|c|}
\hline $\begin{array}{l}\text { Bldg } \\
\text { No. }\end{array}$ & $\begin{array}{l}\text { Year } \\
\text { Built }\end{array}$ & Original Use & $\begin{array}{l}\text { NR } \\
\text { Criteria }\end{array}$ & Re-roofed & $\begin{array}{l}\text { Window } \\
\text { Mods }\end{array}$ & $\begin{array}{l}\text { Door } \\
\text { Mods }\end{array}$ & $\begin{array}{l}\text { Other Mods, } \\
\text { Adds }\end{array}$ & Integrity \\
\hline 435 & 1930 & Student Officers' Apts & $A, C$ & $x$ & $x$ & $x$ & - & yes \\
\hline 436 & 1930 & Student Officers' Apts & $A, C$ & $x$ & $x$ & $\mathrm{x}$ & - & yes \\
\hline 437 & 1930 & Student Officers' Apts & $A, C$ & $x$ & $x$ & $x$ & - & yes \\
\hline 438 & 1928 & Student Officers' Apts & $A, C$ & $x$ & $x$ & $x$ & - & yes \\
\hline 439 & 1928 & Student Officers' Apts & $A, C$ & $x$ & $x$ & $\mathrm{X}$ & - & yes \\
\hline 440 & 1928 & Student Officers' Apts & $A, C$ & $x$ & $x$ & $\mathrm{X}$ & - & yes \\
\hline 441 & 1928 & Student Officers' Apts & $A, C$ & $x$ & $x$ & $x$ & - & yes \\
\hline 442 & 1940 & Garage & $A, C$ & $x$ & - & $x$ & - & yes \\
\hline 443 & 1940 & Garage & $A, C$ & $x$ & - & $x$ & - & yes \\
\hline 444 & 1928 & Student Officers' Apts & $A, C$ & $x$ & $x$ & $x$ & - & yes \\
\hline 510 & 1931 & Nurses' Qtrs/Grimes Hall & $A, C$ & $x$ & $x$ & $x$ & $x$ & yes \\
\hline 520 & 1939 & Dbl NCO Q & $A, C$ & $x$ & $x$ & $x$ & - & yes \\
\hline 521 & 1940 & Garage & $A, C$ & - & - & $x$ & - & yes \\
\hline 523 & 1939 & Dbl NCO Q & $A, C$ & $x$ & $x$ & $x$ & - & yes \\
\hline 524 & 1925 & Civ Fire Chief's Qtrs & C & $x$ & $\mathrm{x}$ & $\mathrm{X}$ & $x$ & yes \\
\hline 525 & 1930 & Dbl NCO Q & $A, C$ & $x$ & $x$ & $\mathrm{X}$ & - & yes \\
\hline 527 & 1940 & Garage & $A, C$ & - & - & $x$ & - & yes \\
\hline 529 & 1931 & Dbl NCO Q & $A, C$ & $x$ & $x$ & $\mathrm{X}$ & - & yes \\
\hline 531 & 1931 & Dbl NCO Q & $A, C$ & $x$ & $x$ & $x$ & - & yes \\
\hline 533 & 1940 & Garage & $A, C$ & - & - & $x$ & - & yes \\
\hline 535 & 1939 & Dbl NCO Q & $A, C$ & $x$ & $x$ & $x$ & - & yes \\
\hline 741 & 1932 & Marshall Field Hangar & $A, C$ & $x$ & - & $x$ & $x$ & yes \\
\hline 755 & 1934 & $\mathrm{NCO} Q$ & $A, C$ & $x$ & - & - & - & yes \\
\hline 757 & 1934 & $\mathrm{NCO} Q$ & $A, C$ & $x$ & - & - & - & yes \\
\hline 759 & 1934 & NCO Q & $A, C$ & $x$ & - & - & - & yes \\
\hline 760 & 1934 & Barracks & $A, C$ & $x$ & - & - & - & yes \\
\hline 761 & 1934 & $\mathrm{NCO} Q$ & $A, C$ & $x$ & - & - & - & yes \\
\hline 763 & 1934 & NCO Garages & $A, C$ & $x$ & - & $x$ & - & yes \\
\hline 765 & 1934 & $\mathrm{NCO} Q$ & $A, C$ & $x$ & - & - & - & yes \\
\hline 767 & 1934 & $\mathrm{NCO} Q$ & $A, C$ & $x$ & - & - & - & yes \\
\hline 780 & 1934 & $\mathrm{CO} O \mathrm{OQ}$ & $A, C$ & $x$ & $x$ & - & - & yes \\
\hline 782 & 1934 & $\mathrm{COOQ}$ & $A, C$ & $x$ & $x$ & - & - & yes \\
\hline 784 & 1934 & $\mathrm{CO} O \mathrm{Q}$ & $A, C$ & $x$ & $x$ & - & - & yes \\
\hline
\end{tabular}




\begin{tabular}{|l|l|l|l|c|l|c|l|l|}
\hline $\begin{array}{l}\text { Bldg } \\
\text { No. }\end{array}$ & $\begin{array}{l}\text { Year } \\
\text { Built }\end{array}$ & Original Use & $\begin{array}{l}\text { NR } \\
\text { Criteria }\end{array}$ & Re-roofed & $\begin{array}{l}\text { Window } \\
\text { Mods }\end{array}$ & $\begin{array}{l}\text { Door } \\
\text { Mods }\end{array}$ & $\begin{array}{l}\text { Other Mods, } \\
\text { Adds }\end{array}$ & \begin{tabular}{l} 
Integrity \\
\hline 786
\end{tabular} \\
\hline 1934 & CO OQ & A, C & $X$ & $X$ & - & - & yes \\
\hline 788 & 1934 & CO OQ & A, C & $X$ & $X$ & $X$ & - & yes \\
\hline
\end{tabular}

Table 10. Reassessment of integrity of the WPA Camp Thematic Group.

\begin{tabular}{|l|l|l|l|l|l|l|l|l|}
\hline $\begin{array}{l}\text { Bldg } \\
\text { No. }\end{array}$ & $\begin{array}{l}\text { Year } \\
\text { Built }\end{array}$ & $\begin{array}{l}\text { Original } \\
\text { Use }\end{array}$ & $\begin{array}{l}\text { NR } \\
\text { Criteria }\end{array}$ & Re-roofed- & $\begin{array}{l}\text { Window } \\
\text { Mods }\end{array}$ & $\begin{array}{l}\text { Door } \\
\text { Mods }\end{array}$ & $\begin{array}{l}\text { Other Mods, } \\
\text { Adds }\end{array}$ & Integrity \\
\hline 315 & 1935 & Warehouse & A, C & unknown & unknown & unknown & unknown & yes \\
\hline 317 & 1935 & Warehouse & A, C & unknown & unknown & unknown & unknown & yes \\
\hline 319 & 1936 & Instruction Bldg & A,C & unknown & X & X & unknown & no414 \\
\hline
\end{tabular}

Table 11. Reassessment of integrity of the World War II Build-Up Thematic Group.

\begin{tabular}{|c|l|l|l|c|l|c|l|l|}
\hline $\begin{array}{l}\text { Bldg } \\
\text { No. }\end{array}$ & $\begin{array}{l}\text { Year } \\
\text { Built }\end{array}$ & $\begin{array}{l}\text { Original } \\
\text { Use }\end{array}$ & $\begin{array}{l}\text { NR } \\
\text { Criteria }\end{array}$ & Re-roofed & $\begin{array}{l}\text { Window } \\
\text { Mods }\end{array}$ & $\begin{array}{l}\text { Door } \\
\text { Mods }\end{array}$ & $\begin{array}{l}\text { Other Mods, } \\
\text { Adds }\end{array}$ & Integrity \\
\hline 29 & 1941 & Red Cross Bldg & A, C & $X$ & $X$ & $X$ & $X$ & yes \\
\hline 743 & 1941 & AF Ops Bldg & A, C & X & $X$ & $X$ & - & yes \\
\hline 751 & 1941 & Vehicle Storage Shed & A, C & $X$ & $X$ & $X$ & - & yes \\
\hline
\end{tabular}




\section{Appendix D: Proposed Historic Districts at Fort Riley, 1993 Study}

Many structures documented in this report fall into eight groups or districts:

1. Cavalry Post

2. Artillery Post

3. QM Supply/ Service District

4. Hospital/ Post Headquarters District

5. Marshall Army Airfield

6. Officers' Family Housing District

7. Student Officers' Apartments District

8. Packers Camp

The districts at Fort Riley developed as a result of various building programs, and like most military installations, these building programs center around periods of conflict. Most of the districts are based on a combination of period, style, and function.

Below is a description of each proposed district, a discussion of the rationale behind the assignment of the district ratings, and a discussion of the historic influences that led to the formation of the proposed district. A list of buildings constituting the representative districts follows the general district descriptions. Included in these lists are: year built, original use, and rating for each building describing its own level of contribution to the district of which it is a member. For a description of the rating system used, see Appendix A.

\section{Cavalry Post}

This district is comprised of eighty-seven buildings, all of limestone. It is significant as an early master planning entity and each of the buildings within it are significant for their representation of Kansas limestone construction. The Cavalry Post is located at the site of the original Camp Center and therefore includes some of the oldest extant buildings at Fort Riley. 
Four structures (Buildings 3, 24, 123, and 205) predate the Civil War and Building 21 is a reconstruction representative of the pre-Civil War quarters that originally occupied its site. Of these particular buildings, all but one have been given a rating of 1 . Unfortunately, Building 205 has been significantly altered. The addition of wings and a clock tower, coupled with numerous modifications to the interior to accommodate the U. S. Cavalry Museum, resulted in a rating of 2 . Buildings 180 through 185, the post laundry facilities, do not contribute to the district for various reasons. Buildings 183, 184, and 185 are temporary structures and therefore excluded from this study. Building 180, in limestone, is degraded by the addition of Building 181, in brick. Fort Riley possesses far too many good examples of Kansas limestone construction to save those with unsympathetic additions. Building 182 is purely functional in nature and contributes little to its surrounds. The same is true of Building 209. Most of the remaining non-contributing structures do not predate 1946 and therefore are excluded from this study. However, we should mention that Building 211 (1946) will need to be reviewed in the near future. [Building 29 is not owned by Fort Riley]

Table 12. Cavalry Post: District Membership and Ratings.

\begin{tabular}{|c|l|l|c|}
\hline Bldg\# & $\begin{array}{l}\text { Year } \\
\text { Built }\end{array}$ & Original Use & Rating \\
\hline 1 & 1888 & Cavalry Post CG OQ & 2 \\
\hline $1 G$ & 1935 & Garage & 4 \\
\hline 2 & 1889 & Cavalry Post OQ & 2 \\
\hline 3 & 1855 & Post Chapel & 1 \\
\hline 4 & 1903 & Cavalry Post OQ & 2 \\
\hline 5 & 1904 & Cavalry Post OQ & 2 \\
\hline 6 & 1897 & Post Chapel & 2 \\
\hline 7 & 1887 & Cavalry Post OQ & 2 \\
\hline 8 & 1887 & Cavalry Post OQ & 2 \\
\hline 9 & 1890 & Cavalry Post OQ & 2 \\
\hline 10 & 1890 & Cavalry Post OQ & 2 \\
\hline 11 & 1887 & Cavalry Post OQ & 2 \\
\hline 12 & 1887 & Cavalry Post OQ & 2 \\
\hline 13 & 1894 & Cavalry Post OQ & 2 \\
\hline 14 & 1894 & Cavalry Post OQ & 2 \\
\hline 15 & 1889 & Cavalry Post OQ & \\
\hline & & & 2 \\
\hline
\end{tabular}




\begin{tabular}{|c|c|c|c|}
\hline Bldg\# & $\begin{array}{l}\text { Year } \\
\text { Built }\end{array}$ & Original Use & Rating \\
\hline 16 & 1893 & Cavalry Post OQ & 2 \\
\hline 17 & 1889 & Cavalry Post OQ & 2 \\
\hline 18 & 1903 & Cavalry Post OQ & 2 \\
\hline 19 & 1890 & Cavalry Post OQ & 2 \\
\hline 20 & 1897 & Cavalry Post OQ & 2 \\
\hline 21 & 1858 & Cavalry Post OQ & 1 \\
\hline 22 & 1887 & Cavalry Post OQ & 2 \\
\hline 23 & 1886 & Cavalry Post OQ & 2 \\
\hline 24 & 1855 & Cavalry Post OQ & 1 \\
\hline 25 & 1887 & Cavalry Post OQ & 2 \\
\hline 26 & 1889 & Cavalry Post OQ & 2 \\
\hline 27 & 1909 & Arnold Hall/BOQ Bks & 3 \\
\hline 28 & 1889 & Dispensary & 3 \\
\hline 29 & 1941 & Red Cross Bldg & 3 \\
\hline 30 & 1940 & Garage & 4 \\
\hline 31 & 1940 & Garage & 4 \\
\hline 45 & 1904 & Carr Hall/BOQ Bks & 3 \\
\hline 46 & 1940 & Garage & 4 \\
\hline 47 & 1940 & Garage & 4 \\
\hline 48 & 1940 & Garage & 4 \\
\hline 123 & 1855 & Chaplain's Qtrs & 1 \\
\hline 170 & 1888 & Sutler's Store/Waters Hall & 3 \\
\hline 200 & 1940 & Patton Hall/Academic Bldg & 3 \\
\hline 202 & 1889 & Drill Hall & 3 \\
\hline 203 & 1889 & Post Guard House & 3 \\
\hline 205 & 1855 & Post Hosp/Cavalry Admin Bldg & 2 \\
\hline 206 & 1933 & Post Theatre & 3 \\
\hline 207 & 1905 & Regimental HQ & 3 \\
\hline 208 & 1903 & Cavalry Post Bks & 3 \\
\hline 210 & 1889 & Cavalry Post Bks & 3 \\
\hline 212 & 1903 & Cavalry Post Bks & 3 \\
\hline 213 & 1889 & Latrine/Motor School & 3 \\
\hline 214 & 1903 & Cavalry Post Bks & 3 \\
\hline
\end{tabular}




\begin{tabular}{|c|c|c|c|}
\hline Bldg\# & $\begin{array}{l}\text { Year } \\
\text { Built }\end{array}$ & Original Use & Rating \\
\hline 215 & 1886 & Cavalry Post Bks & 3 \\
\hline 216 & 1905 & Guard House & 3 \\
\hline 217 & 1887 & Cavalry Post Bks & 3 \\
\hline 219 & 1887 & Cavalry Post Bks & 3 \\
\hline 221 & 1886 & Cavalry Post Bks & 3 \\
\hline 222 & 1907 & School Stable/Bks & 3 \\
\hline 223 & 1889 & McGill Hall/Cavalry Post Bks & 3 \\
\hline 224 & 1915 & School Stable/Bks & 3 \\
\hline 225 & 1889 & Cavalry Post Latrine & 3 \\
\hline 226 & 1905 & Vet Hospital & 3 \\
\hline 227 & 1908 & Cooks/Bakers Bks & 3 \\
\hline 228 & 1908 & Veterinary Laboratory & 3 \\
\hline 229 & 1908 & Drill Hall & 3 \\
\hline 236 & 1889 & Street Car Station & 3 \\
\hline 240 & 1904 & Farriers Shop & 3 \\
\hline 241 & 1904 & Cavalry Stable Guard House & 3 \\
\hline 246 & 1916 & Blacksmith Shop & 3 \\
\hline 247 & 1905 & Cavalry Stable & 3 \\
\hline 248 & 1938 & Garage & 3 \\
\hline 251 & 1889 & Cavalry Stable & 3 \\
\hline 252 & 1905 & Blacksmith/Carpentry Shop & 3 \\
\hline 253 & 1903 & Cavalry Stable & 3 \\
\hline 255 & 1903 & Cavalry Stable & 3 \\
\hline 257 & 1904 & Cavalry Stable & 3 \\
\hline 259 & 1904 & Cavalry Stable Guard House & 3 \\
\hline 261 & 1904 & Cavalry Stable & 3 \\
\hline 263 & 1904 & Cavalry Stable & 3 \\
\hline 265 & 1904 & Cavalry Stable Guard House & 3 \\
\hline 267 & 1904 & Cavalry Stable & 3 \\
\hline 269 & 1889 & Cavalry Stable & 3 \\
\hline 271 & 1897 & Cavalry Stable Guard House & 3 \\
\hline 273 & 1889 & Cavalry Stable & 3 \\
\hline
\end{tabular}




\begin{tabular}{|c|l|l|c|}
\hline Bldg\# & $\begin{array}{l}\text { Year } \\
\text { Built }\end{array}$ & Original Use & Rating \\
\hline 275 & 1897 & Cavalry Stable Guard House & 3 \\
\hline 277 & 1889 & Cavalry Stable & 3 \\
\hline 279 & 1897 & Cavalry Stable Guard House & 3 \\
\hline 281 & 1912 & Cavalry Stable & 3 \\
\hline 283 & 1897 & Cavalry Stable Guard House & 3 \\
\hline 289 & 1905 & Field/Staff/Band Stable & 3 \\
\hline
\end{tabular}

\section{Artillery Post}

This district is comprised of forty-seven buildings, all of limestone construction. The Artillery Post is located next to the Cavalry Post and is significant as the second major planning entity at Fort Riley. The structures within this district are significant for their representation of Kansas limestone construction. Buildings 85- 100 have been given a rating of 2 because they are exceptional examples of limestone construction and they help define an important landscape feature, the Artillery Parade Field. While nearby barracks and administrative buildings also help define the parade field, they unfortunately had to add several public safety modifications required of public buildings (i.e. fire escape ladders). Such modifications are usually not required of private residences.

Table 13. Artillery Post: District Membership and Ratings.

\begin{tabular}{|c|l|l|c|}
\hline Bldg\# & $\begin{array}{l}\text { Year } \\
\text { Built }\end{array}$ & Original Use & Rating* \\
\hline 85 & 1909 & Arty Post OQ & 2 \\
\hline 86 & 1909 & OQ & 2 \\
\hline 87 & 1909 & Arty Post Field OQ & 2 \\
\hline 88 & 1897 & Arty Post OQ & 2 \\
\hline 89 & 1903 & Arty Post OQ & 2 \\
\hline 90 & 1897 & Arty Post OQ & 2 \\
\hline 91 & 1893 & Arty Post OQ & 2 \\
\hline 92 & 1889 & Arty Post OQ & 2 \\
\hline 93 & 1889 & Arty Post OQ & 2 \\
\hline 94 & 1903 & Arty Post OQ & 2 \\
\hline 95 & 1903 & Arty Post OQ & 2 \\
\hline
\end{tabular}




\begin{tabular}{|c|c|c|c|}
\hline Bldg\# & $\begin{array}{l}\text { Year } \\
\text { Built }\end{array}$ & Original Use & Rating* \\
\hline 96 & 1889 & Arty Post OQ & 2 \\
\hline 97 & 1903 & Arty Post OQ & 2 \\
\hline 98 & 1904 & Arty Post OQ & 2 \\
\hline 99 & 1907 & Art Post Field OQ & 2 \\
\hline 100 & 1887 & Arty Post OQ & 2 \\
\hline 360 & 1889 & Arty Post Stable & 3 \\
\hline 362 & 1889 & Arty Post Stable & 3 \\
\hline 363 & 1909 & Arty Gun Shed & 3 \\
\hline 364 & 1889 & Arty Gun Guard & 3 \\
\hline 366 & 1889 & Arty Post Guard & 3 \\
\hline 367 & 1903 & Arty Gun Shed & 3 \\
\hline 368 & 1889 & Arty Post Stable & 3 \\
\hline 370 & 1904 & Arty Work Shop & 3 \\
\hline 372 & 1889 & Arty Post Stable & 3 \\
\hline 374 & 1904 & Arty Work Shop & 3 \\
\hline 375 & 1903 & Arty Gun Shed & 3 \\
\hline 376 & 1901 & Arty Post Stable & 3 \\
\hline 378 & 1904 & Arty Work Shop & 3 \\
\hline 380 & 1903 & Arty Post Stable & 3 \\
\hline 384 & 1904 & Arty Work Shop & 3 \\
\hline 385 & 1904 & Arty Gun Shed & 3 \\
\hline 386 & 1908 & Arty Post Stable & 3 \\
\hline 387 & 1907 & Arty Gun Shed & 3 \\
\hline 388 & 1907 & Arty Work Shop & 3 \\
\hline 400 & 1907 & Bachelor OQ & 3 \\
\hline 401 & 1940 & Garage (1943 addition) & - \\
\hline 402 & 1903 & Gillis Hall/Arty Post Bks & - \\
\hline 403 & 1889 & Arty Post Admin Bldg & - \\
\hline 404 & 1902 & Fremont Hall/Arty post Bks & - \\
\hline 405 & 1910 & Gym/Arty Post Exchange & - \\
\hline 406 & 1909 & Arty Bank Bks & 3 \\
\hline 407 & 1907 & Arty Post Bks & 3 \\
\hline 408 & 1909 & Arty Guard House & - \\
\hline
\end{tabular}




\begin{tabular}{|c|l|l|c|}
\hline Bldg\# & $\begin{array}{l}\text { Year } \\
\text { Built }\end{array}$ & Original Use & Rating* \\
\hline 409 & 1889 & Gillis Hall/Arty Post Bks & - \\
\hline 410 & 1897 & Rose Hall/Arty Post Bks & - \\
\hline 411 & 1889 & Waybur Hall/Arty Post Bks & - \\
\hline 550 & 1891 & Magazine & - \\
\hline
\end{tabular}

* Properties with ratings showing a dash indicate no rating was given in the 1993 report that this data was drawn from.

\section{QM Supply/Service District}

This district is comprised of seventeen buildings, and all but one (Building 306) is limestone construction. The QM Supply/ Service District is located between and to the south of the Cavalry and Artillery Posts. These structures served their respective functions in support of the Cavalry and Artillery Posts. Most are significant for their representation of Kansas limestone construction. Building 306, however, represents the only 19thcentury single-family brick residence extant at Fort Riley, and thus its rating of 2 .

Several buildings near the railroad do not predate 1946, and those that do were considered non-contributing (such as open warehouses). Buildings $313,315,317$, and 319 do not possess those characteristics necessary for inclusion in an historic district. While Buildings 334, 336, and 338 are of limestone construction, unsympathetic modifications prevent them from inclusion in the proposed QM Supply/ Service District. Building 354 is in such a state of disrepair, that most of its integrity is gone.

Table 14. QM Supply/Service District: District Membership and Ratings.

\begin{tabular}{|l|l|l|l|}
\hline Bldg\# & $\begin{array}{l}\text { Year } \\
\text { Built }\end{array}$ & Original Use & Rating \\
\hline 300 & 1890 & Granary & 3 \\
\hline 301 & 1892 & QM/Commissary Store & 3 \\
\hline 302 & 1908 & QM Storehouse & 3 \\
\hline 303 & 1905 & $\begin{array}{l}\text { Subsistence } \\
\text { Storehouse }\end{array}$ & 3 \\
\hline 304 & 1890 & Coal Shed & 3 \\
\hline 305 & 1889 & Heating Plant & 3 \\
\hline 306 & 1889 & Engr Qtrs & 2 \\
\hline
\end{tabular}




\begin{tabular}{|l|l|l|l|}
\hline Bldg\# & $\begin{array}{l}\text { Year } \\
\text { Built }\end{array}$ & Original Use & Rating \\
\hline 307 & 1900 & Ordnance Storehouse & 3 \\
\hline 308 & 1904 & Ordnance Storehouse & 3 \\
\hline 309 & 1906 & Vegetable Store & 3 \\
\hline 310 & 1902 & Bakery & 3 \\
\hline 330 & 1936 & Teamsters' Qtrs & 3 \\
\hline 332 & 1897 & QM Stable & 3 \\
\hline 335 & 1897 & Wagonmaster's Office & 3 \\
\hline 337 & 1897 & Teamsters' Mess/Shop & 3 \\
\hline 350 & 1908 & Granary & 3 \\
\hline 352 & 1909 & QM Stable & 3 \\
\hline
\end{tabular}

\section{Hospital/Post Headquarters District}

This district is comprised of five buildings and is located north of the Artillery Post. The grouping originally served as the Fort hospital and now serves as Post Headquarters. Buildings 500, 505, and 509 are significant for their representation of Kansas limestone construction, Building 510 is significant as an example of the Colonial Revival Style, and Building 507 is significant as a wood-framed Folk Victorian cottage. While Building 507 is one of four Folk Victorian buildings at Fort Riley, it possesses a particularly delicate quality that the other examples in brick (Buildings 165, 166, and 167) do not possess, and thus its rating of 2 .

Table 15. Hospital/Post Headquarters District: District Membership and Ratings.

\begin{tabular}{|l|l|l|l|}
\hline Bldg\# & $\begin{array}{l}\text { Year } \\
\text { Built }\end{array}$ & Original Use & Rating \\
\hline 500 & 1889 & Hosp/Post HQ (additions) & 3 \\
\hline 505 & 1909 & Hosp NCO Qtrs & 3 \\
\hline 507 & 1891 & Hosp Steward Qtrs & 2 \\
\hline 509 & 1910 & Isolation Hospital & 3 \\
\hline 510 & 1931 & Nurses' Qtrs/Grimes Hall & 3 \\
\hline
\end{tabular}

\section{Marshall Army Airfield}

This district is comprised of seventeen buildings and is located across the Kansas River, to the south of the main post. Marshall Army Airfield con- 
sists of two predominant building types, residential and aviation-related structures. Buildings 741, 743, and 751 are significant for their association with the evolution of military aviation, and to a lesser extent for their representation of a type of construction (early aviation architecture). Buildings 748 and 763 are significant as a representation of Kansas limestone construction. Buildings 755, 757, 759, 760, 761, 765, and 767 represent the Neoclassical Style, while Buildings 780, 782, 784, 786, and 788 are significant as examples of the Colonial Revival Style. Most of the other buildings at the airfield do not predate 1946.

Table 16. Marshall Army Airfield: District Membership and Ratings.

\begin{tabular}{|l|l|l|l|}
\hline Bldg\# & $\begin{array}{l}\text { Year } \\
\text { Built }\end{array}$ & Original Use & Rating \\
\hline 741 & 1932 & Marshall Field Hangar & 3 \\
\hline 743 & 1941 & $\begin{array}{l}\text { unknown (now a AF Ops } \\
\text { Bldg) }\end{array}$ & 3 \\
\hline 748 & 1907 & Polo Bungalow & 3 \\
\hline 751 & 1941 & Vehicle Storage Shed & 3 \\
\hline 755 & 1934 & NCO Q & 3 \\
\hline 757 & 1934 & NCO Q & 3 \\
\hline 759 & 1934 & NCO Q & 3 \\
\hline 760 & 1934 & Barracks & 3 \\
\hline 761 & 1934 & NCO Q & 3 \\
\hline 763 & 1934 & NCO Garages & 4 \\
\hline 765 & 1934 & NCO Q & 3 \\
\hline 767 & 1934 & NCO Q & 3 \\
\hline 780 & 1934 & CO OQ & 3 \\
\hline 782 & 1934 & CO OQ & 3 \\
\hline 784 & 1934 & CO OQ & 3 \\
\hline 786 & 1934 & CO OQ & 3 \\
\hline 788 & 1934 & CO OQ & 3 \\
\hline & & & 3 \\
\hline
\end{tabular}




\section{Officers' Family Housing District}

This district is comprised of sixty-five buildings, most of limestone or brick construction. Historic officer family housing (including associated garages and a fire station) is located throughout the main post at Fort Riley. As a result, this district does not appear on the installation map as a contiguous entity. Most are significant for their representation of Kansas limestone construction or the Colonial Revival Style, with the exception of a stucco example, Building 150. Some of these buildings are also significant for their cluster arrangement. Further discussion of building clusters will appear in the landscape portion of the Historic Resources Management Plan.

Table 17. Officers' Family Housing District: District Membership and Ratings.

\begin{tabular}{|c|l|l|l|}
\hline Bldg\# & $\begin{array}{l}\text { Year } \\
\text { Built }\end{array}$ & Original Use & Rating \\
\hline 70 & 1934 & Field OQ & 3 \\
\hline 72 & 1934 & Field OQ & 3 \\
\hline 74 & 1934 & Field OQ & 3 \\
\hline 76 & 1934 & Field OQ & 3 \\
\hline 78 & 1934 & Field OQ & 3 \\
\hline 80 & 1934 & Field OQ & 3 \\
\hline 82 & 1934 & Field OQ & 3 \\
\hline 125 & 1939 & Dbl NCO Qtrs & 3 \\
\hline 126 & 1939 & Dbl NCO Qtrs & 3 \\
\hline 127 & 1939 & Garage for 125 & 4 \\
\hline 128 & 1939 & Garage for 126 & 4 \\
\hline 129 & 1939 & Dbl NCO Qtrs & 3 \\
\hline 130 & 1939 & Dbl NCO Qtrs & 3 \\
\hline 131 & 1939 & Garage for 129 & 4 \\
\hline 132 & 1939 & Garage for 130 & 4 \\
\hline 133 & 1939 & Dbl NCO Qtrs & 3 \\
\hline 134 & 1939 & Dbl NCO Qtrs & 3 \\
\hline 135 & 1939 & Garage for 133 & 4 \\
\hline 136 & 1939 & Garage for 134 & 4 \\
\hline 137 & 1939 & Dbl NCO Qtrs & 3 \\
\hline 138 & 1939 & Dbl NCO Qtrs & 3 \\
\hline
\end{tabular}




\begin{tabular}{|l|l|l|l|}
\hline Bldg\# & $\begin{array}{l}\text { Year } \\
\text { Built }\end{array}$ & Original Use & Rating \\
\hline 139 & 1939 & Garage for 137 & 4 \\
\hline 140 & 1939 & Garage for 138 & 4 \\
\hline 141 & 1939 & Dbl NCO Qtrs & 3 \\
\hline 142 & 1939 & Dbl NCO Qtrs & 3 \\
\hline 143 & 1939 & Garage for 141 & 4 \\
\hline 144 & 1939 & Garage for 142 & 4 \\
\hline 150 & 1910 & Civilians Qtrs & 3 \\
\hline 152 & 1903 & NCO Qtrs & 3 \\
\hline 153 & 1938 & Dbl NCO Qtrs & 3 \\
\hline 154 & 1940 & Garage & 4 \\
\hline 155 & 1903 & NCO Qtrs & 3 \\
\hline 156 & 1905 & NCO Qtrs & 3 \\
\hline 157 & 1931 & Dbl NCO Qtrs & 3 \\
\hline 158 & 1940 & Garage & 4 \\
\hline 159 & 1931 & Dbl NCO Qtrs & 3 \\
\hline 160 & 1931 & Dbl NCO Qtrs & 3 \\
\hline 161 & 1931 & Dbl NCO Qtrs & 3 \\
\hline 162 & 1931 & Dbl NCO Qtrs & 3 \\
\hline 163 & 1940 & Garage & 4 \\
\hline 164 & 1931 & Dbl NCO Qtrs & 3 \\
\hline 165 & 1889 & NCO Qtrs & 3 \\
\hline 166 & 1889 & NCO Qtrs & 3 \\
\hline 167 & 1889 & NCO Qtrs & 3 \\
\hline 415 & 1930 & Double NCO Q & 3 \\
\hline 416 & 1930 & Double NCO Q & 3 \\
\hline 417 & 1930 & Double NCO Q & 3 \\
\hline 418 & 1930 & Double NCO Q & 3 \\
\hline 419 & 1930 & Double NCO Q & 3 \\
\hline 420 & 1930 & Double NCO Q & 3 \\
\hline 422 & 1930 & Double NCO Q & 3 \\
\hline 423 & 1930 & Double NCO Q & 3 \\
\hline 424 & 1930 & Double NCO Q & 3 \\
\hline
\end{tabular}




\begin{tabular}{|l|l|l|l|}
\hline Bldg\# & $\begin{array}{l}\text { Year } \\
\text { Built }\end{array}$ & Original Use & Rating \\
\hline 425 & 1909 & NCO Qtrs & 3 \\
\hline 426 & 1909 & NCO Qtrs & 3 \\
\hline 430 & 1932 & Fire Station & 3 \\
\hline 520 & 1939 & Dbl NCO Q & 3 \\
\hline 521 & 1940 & Garage & - \\
\hline 523 & 1939 & Dbl NCO Q & 3 \\
\hline 524 & 1925 & Civ Fire Chief's Qtrs & - \\
\hline 525 & 1930 & Dbl NCO Q & 3 \\
\hline 527 & 1940 & Garage & 4 \\
\hline 529 & 1931 & Dbl NCO Q & 3 \\
\hline 531 & 1931 & Dbl NCO Q & 3 \\
\hline 533 & 1940 & Garage & 4 \\
\hline 535 & 1939 & Dbl NCO Q & 3 \\
\hline
\end{tabular}

* Properties with ratings showing a dash indicate no rating was given in the 1993 report that this data was drawn from.

\section{Student Officers' Apartments District}

This district is comprised of twenty-four buildings, most of brick construction. Like officer family housing, student officer housing (including associated garages) is located throughout the main post. As a result, this district also does not appear on the installation map as a contiguous entity. Most structures are significant as examples of the Colonial Revival Style.

Apartments on Huebner Road, as well as all garages, are significant for their representation of Kansas limestone construction. Again, like officer family housing, the occasional clustering of these buildings has planning significance.

Table 18. Student Officers' Apartments District: District Membership and Ratings.

\begin{tabular}{|r|l|l|l|}
\hline BIdg\# & $\begin{array}{l}\text { Year } \\
\text { Built }\end{array}$ & Original Use & Rating \\
\hline 40 & 1934 & Student Officers' Apts & 3 \\
\hline 41 & 1934 & Student Officers' Apts & 3 \\
\hline 102 & 1940 & Garage & 4 \\
\hline
\end{tabular}




\begin{tabular}{|l|l|l|l|}
\hline Bldg\# & $\begin{array}{l}\text { Year } \\
\text { Built }\end{array}$ & ' Rriginal Use & \\
\hline 106 & 1934 & 'tudent Officers' Apts & 3 \\
\hline 108 & 1934 & Student Officers' Apts & 3 \\
\hline 110 & 1910 & OQ & 3 \\
\hline 112 & 1940 & Garage for 110 \& 114 & 4 \\
\hline 114 & 1910 & OQ & 3 \\
\hline 116 & 1940 & Garage for 118 & 4 \\
\hline 118 & 1934 & Student Officers' Apts & 3 \\
\hline 431 & 1940 & Garage & 4 \\
\hline 432 & 1934 & Student Officers' Apts & 3 \\
\hline 433 & 1934 & Student Officers' Apts & 3 \\
\hline 434 & 1940 & Garage & 4 \\
\hline 435 & 1930 & Student Officers' Apts & 3 \\
\hline 436 & 1930 & Student Officers' Apts & 3 \\
\hline 437 & 1930 & Student Officers' Apts & 3 \\
\hline 438 & 1928 & Student Officers' Apts & 3 \\
\hline 439 & 1928 & Student Officers' Apts & 3 \\
\hline 440 & 1928 & Student Officers' Apts & 3 \\
\hline 441 & 1928 & Student Officers' Apts & 3 \\
\hline 442 & 1940 & Garage & 4 \\
\hline 443 & 1940 & Garage & 4 \\
\hline 444 & 1928 & Student Officers' Apts & 3 \\
\hline
\end{tabular}

\section{Packer's Camp}

Buildings 1020 and 1022 are the only structures included in this district and both are of Kansas limestone construction. This was the site of the old Packers Camp, established in the days when the Army depended on long mule pack trains to haul supplies (see Historical Overview). Building 1020 was a living quarters for the packers, muleskinners, and farriers, and Building 1022 was a blacksmith shop. These structures are significant for their method and materials of construction. 
Table 19. Packer's Camp: District Membership and Ratings.

\begin{tabular}{|c|l|l|l|}
\hline Bldg\# & Year Built & Original Use & Rating \\
\hline 1020 & 1911 & Quarters for Packers & 3 \\
\hline 1022 & 1914 & Blacksmith Shop & 3 \\
\hline
\end{tabular}




\section{Appendix E: Proposed Historic Districts and Thematic Groups (Revised, 1994)}

An NRHP Historic District is a geographically definable area possessing a significant concentration, linkage, or continuity of sites, buildings, structures, and/ or objects united by past events or aesthetically by plan or physical development. Historic districts are usually areas of contiguous historic properties. The close proximity of the properties included in the district helps to maintain the sense of a coherent and related group that represents a specific period of time, or function.

\section{Historic districts at Fort Riley}

The following are the historic district designations at Fort Riley, as established by the ERDC-CERL study conducted in 1993 (and revised in 1994):

Main Post Historic District: Four thematic groups are represented within this district's boundary: (1) the Cavalry and Artillery Thematic Group, (2) the 1927-1940 Thematic Group, (3) the WPA Camp Thematic Group, and (4) the World War II Build-Up Thematic Group.

Note: Building 524, the Civilian Chief's Quarters, was built in 1925 and therefore does not fall within the periods of significance associated with the following suggested thematic groups. However, we recommend that this building be included as part of the Main Post Historic District. It is one of the few residences built for civilian personnel at the post and is a fine example of the simple Bungalow.

Marshall Army Airfield (MAA) Historic District: This district is located across the Kansas River, to the south of the main post. It contains three thematic groups: (1) the Cavalry and Artillery Thematic Group (Building 748), (2) the 1927-1940 Thematic Group, and (3) the World War II Build-Up Thematic Group.

Packer's Camp (PC) Historic District: Located about five miles northeast of the main post, this was the site of the old Packers Camp. Mule 
pack trains were readied at this site from 1901 to 1914. The two buildings in this district are part of the Cavalry and Artillery Thematic Group.

\section{Thematic groups}

Buildings were placed in thematic groups within the districts based on their association with a definitive historic period of significance. The structures documented in this report fall into five thematic groups (for a full breakdown for all buildings, see tables in Appendix B).

Original Post Thematic Group (1850s): This thematic group is made up of the few remaining permanent buildings erected at Fort Riley during its initial construction period which took place in the 1850s. Originally Fort Riley was an early frontier outpost that offered protection to traders and settlers traveling along the Santa Fe, Oregon, and Smoky Hill Trails. Its establishment was a definitive step toward the settlement and development of the Kansas territory.

Cavalry and Artillery Thematic Group (1886-1916): This thematic group is made up of the permanent buildings associated with the establishment of the Cavalry and Light Artillery School. It is a cohesive architectural environment based on Captain George Pond's 1887 plan for the post. The establishment of this school marked the beginning of Fort Riley's recognition as an important center of advanced military training.

1927-1940 Thematic Group (1927-1940): This group is made up of permanent buildings constructed at Fort Riley during the major nationwide Army building program that began in 1927. In some cases, funds were used from government work programs created during the Great Depression. These buildings contribute to an understanding of the twentieth century historical development of the installation. Most of the housing included in this group is situated in areas visually separated from Pond's 1887 plan and most buildings feature Colonial Revival style details. Buildings in this group were usually built around open courts or facing open greens, exemplifying the type of planning that was popular at the time.

Garages are listed as part of this thematic group because of their association with nearby housing. Although these structures make little significant contribution to their group, they are constructed of appropriate building materials and are a functional aspect of their associated structure. 
WPA Camp Thematic Group: This group is made up of four buildings that are associated with the old Works Progress Administration (WPA) Camp. The camp was located at Fort Riley from 1935 to 1942 and housed men participating in the WPA work program. Besides relieving the Kansas unemployment situation, it provided Fort Riley with a much needed labor pool during a period of expansion.

World War II Build-Up Thematic Group: This group is made up of significant permanent buildings associated with the installation's build-up just prior to World War II. These buildings contribute to an understanding of the twentieth century historical development of the installation.

The following tables depict the buildings through 1945 within each thematic group:

Table 20. Original Post Thematic Group

\begin{tabular}{|r|l|l|}
\hline Bldg\# & $\begin{array}{l}\text { Year } \\
\text { Built }\end{array}$ & Original Use \\
\hline 3 & 1855 & Post Chapel \\
\hline 21 & 1858 & Cavalry Post OQ \\
\hline 24 & 1855 & Cavalry Post OQ \\
\hline 123 & 1855 & Chaplain's Qtrs \\
\hline 205 & 1855 & Post Hosp/Cavalry Admin Bldg \\
\hline
\end{tabular}

Table 21. Cavalry and Artillery Thematic Group

\begin{tabular}{|r|l|l|l|}
\hline Bldg\# & Year Built & Original Use & $\begin{array}{l}\text { District (if other } \\
\text { than Main Post) }\end{array}$ \\
\hline 1 & 1888 & Cavalry Post OQ & \\
\hline 2 & 1889 & Cavalry Post OQ & \\
\hline 4 & 1903 & Cavalry Post OQ & \\
\hline 5 & 1904 & Cavalry Post OQ & \\
\hline 6 & 1897 & Post Chapel & \\
\hline 7 & 1887 & Cavalry Post OQ & \\
\hline 8 & 1887 & Cavalry Post OQ & \\
\hline 9 & 1890 & Cavalry Post OQ & \\
\hline 10 & 1890 & Cavalry Post OQ & \\
\hline 11 & 1887 & Cavalry Post OQ & \\
\hline
\end{tabular}




\begin{tabular}{|c|c|c|c|}
\hline Bldg\# & Year Built & Original Use & $\begin{array}{l}\text { District (if other } \\
\text { than Main Post) }\end{array}$ \\
\hline 12 & 1887 & Cavalry Post $\mathrm{OQ}$ & \\
\hline 13 & 1894 & Cavalry Post OQ & \\
\hline 14 & 1894 & Cavalry Post OQ & \\
\hline 15 & 1889 & Cavalry Post $\mathrm{OQ}$ & \\
\hline 16 & 1893 & Cavalry Post OQ & \\
\hline 17 & 1889 & Cavalry Post OQ & \\
\hline 18 & 1903 & Cavalry Post OQ & \\
\hline 19 & 1890 & Cavalry Post OQ & \\
\hline 20 & 1897 & Cavalry Post OQ & \\
\hline 22 & 1887 & Cavalry Post OQ & \\
\hline 23 & 1886 & Cavalry Post OQ & \\
\hline 25 & 1887 & Cavalry Post OQ & \\
\hline 26 & 1889 & Cavalry Post OQ & \\
\hline 27 & 1909 & Arnold Hall/BOQ Bks & \\
\hline 28 & 1889 & Dispensary & \\
\hline 45 & 1904 & Carr Hall/BOQ Bks & \\
\hline 85 & 1909 & Artillery Post OQ & \\
\hline 86 & 1909 & $\mathrm{OQ}$ & \\
\hline 87 & 1909 & Artillery Post Field OQ & \\
\hline 88 & 1897 & Artillery Post OQ & \\
\hline 89 & 1903 & Artillery Post OQ & \\
\hline 90 & 1897 & Artillery Post OQ & \\
\hline 91 & 1893 & Artillery Post OQ & \\
\hline 92 & 1889 & Artillery Post OQ & \\
\hline 93 & 1889 & Artillery Post OQ & \\
\hline 94 & 1903 & Artillery Post OQ & \\
\hline 95 & 1903 & Artillery Post OQ & \\
\hline C96 & 1889 & Artillery Post OQ & \\
\hline 97 & 1903 & Artillery Post OQ & \\
\hline 98 & 1904 & Artillery Post OQ & \\
\hline 99 & 1907 & Art Post Field OQ & \\
\hline 100 & 1887 & Artillery Post OQ & \\
\hline 110 & 1910 & OQ & \\
\hline
\end{tabular}




\begin{tabular}{|c|c|c|c|}
\hline Bldg\# & Year Built & Original Use & $\begin{array}{l}\text { District (if other } \\
\text { than Main Post) }\end{array}$ \\
\hline 114 & 1910 & OQ & \\
\hline 150 & 1910 & Civilians Qtrs & \\
\hline 152 & 1903 & NCO Qtrs & \\
\hline 155 & 1903 & NCO Qtrs & \\
\hline 156 & 1905 & NCO Qtrs & \\
\hline 165 & 1889 & NCO Qtrs & \\
\hline 166 & 1889 & NCO Qtrs & \\
\hline 167 & 1889 & NCO Qtrs & \\
\hline 170 & 1888 & Sutler's Store/Waters Hall & \\
\hline 202 & 1889 & Drill Hall & \\
\hline 203 & 1889 & Post Guard House & \\
\hline 207 & 1905 & Regimental HQ & \\
\hline 208 & 1903 & Cavalry Post Bks & \\
\hline 210 & 1889 & Cavalry Post Bks & \\
\hline 211 & 1889,1946 & Cavalry Post Bks & \\
\hline 212 & 1903 & Cavalry Post Bks & \\
\hline 213 & 1889 & Latrine/Motor School & \\
\hline 214 & 1903 & Cavalry Post Bks & \\
\hline 215 & 1886 & Cavalry Post Bks & \\
\hline 216 & 1905 & Guard House & \\
\hline 217 & 1887 & Cavalry Post Bks & \\
\hline 219 & 1887 & Cavalry Post Bks & \\
\hline 221 & 1886 & Cavalry Post Bks & \\
\hline 222 & 1907 & School Stable/Bks & \\
\hline 223 & 1889 & McGill Hall/Cavalry Post Bks & \\
\hline 224 & 1915 & School Stable/Bks & \\
\hline 225 & 1889 & Cavalry Post Latrine & \\
\hline 226 & 1905 & Vet Hospital & \\
\hline 227 & 1908 & Cooks/Bakers Bks & \\
\hline 228 & 1908 & Veterinary Laboratory & \\
\hline 229 & 1908 & Drill Hall & \\
\hline 236 & 1889 & Street Car Station & \\
\hline 240 & 1904 & Farrier's Shop & \\
\hline
\end{tabular}




\begin{tabular}{|c|c|c|c|}
\hline Bldg\# & Year Built & Original Use & $\begin{array}{l}\text { District (if other } \\
\text { than Main Post) }\end{array}$ \\
\hline 241 & 1904 & Cavalry Stable Guard House & \\
\hline 246 & 1916 & Blacksmith Shop & \\
\hline 247 & 1905 & Cavalry Stable & \\
\hline 251 & 1889 & Cavalry Stable & \\
\hline 252 & 1905 & Blacksmith/Carpentry Shop & \\
\hline 253 & 1903 & Cavalry Stable & \\
\hline 255 & 1903 & Cavalry Stable & \\
\hline 257 & 1904 & Cavalry Stable & \\
\hline 259 & 1904 & Cavalry Stable Guard House & \\
\hline 261 & 1904 & Cavalry Stable & \\
\hline 263 & 1904 & Cavalry Stable & \\
\hline 265 & 1904 & Cavalry Stable Guard House & \\
\hline 267 & 1904 & Cavalry Stable & \\
\hline 269 & 1889 & Cavalry Stable & \\
\hline 271 & 1897 & Cavalry Stable Guard House & \\
\hline 273 & 1889 & Cavalry Stable & \\
\hline 275 & 1897 & Cavalry Stable Guard House & \\
\hline 277 & 1889 & Cavalry Stable & \\
\hline 279 & 1897 & Cavalry Stable Guard House & \\
\hline 281 & 1912 & Cavalry Stable & \\
\hline 283 & 1897 & Cavalry Stable Guard House & \\
\hline 289 & 1905 & Field/Staff/Band Stable & \\
\hline 300 & 1890 & Granary & \\
\hline 301 & 1892 & QM/Commissary Store & \\
\hline 302 & 1908 & QM Storehouse & \\
\hline 303 & 1905 & Subsistence Storehouse & \\
\hline 304 & 1890 & Coal Shed & \\
\hline 305 & 1889 & Heating Plant & \\
\hline 306 & 1889 & Engineer Qtrs & \\
\hline 307 & 1900 & Ordnance Storehouse & \\
\hline 308 & 1904 & Ordnance Storehouse & \\
\hline 309 & 1906 & Vegetable Store & \\
\hline 310 & 1902 & Bakery & \\
\hline
\end{tabular}




\begin{tabular}{|c|c|c|c|}
\hline Bldg\# & Year Built & Original Use & $\begin{array}{l}\text { District (if other } \\
\text { than Main Post) }\end{array}$ \\
\hline 330 & 1910 & Teamster Qtrs & \\
\hline 332 & 1897 & QM Stable & \\
\hline 335 & 1897 & Wagonmaster Office & \\
\hline 337 & 1897 & Teamster Mess/Shop & \\
\hline 350 & 1908 & Granary & \\
\hline 352 & 1909 & QM Stable & \\
\hline 360 & 1889 & Artillery Post Stable & \\
\hline 362 & 1889 & Artillery Post Stable & \\
\hline 363 & 1909 & Artillery Gun Shed & \\
\hline 364 & 1889 & Artillery Gun Guard & \\
\hline 366 & 1889 & Artillery Post Guard & \\
\hline 367 & 1903 & Artillery Gun Shed & \\
\hline 368 & 1889 & Artillery Post Stable & \\
\hline 370 & 1904 & Artillery Work Shop & \\
\hline 372 & 1889 & Artillery Post Stable & \\
\hline 374 & 1904 & Artillery Work Shop & \\
\hline 375 & 1903 & Artillery Gun Shed & \\
\hline 376 & 1901 & Artillery Post Stable & \\
\hline 378 & 1904 & Artillery Work Shop & \\
\hline 380 & 1903 & Artillery Post Stable & \\
\hline 384 & 1904 & Artillery Work Shop & \\
\hline 385 & 1904 & Artillery Gun Shed & \\
\hline 386 & 1908 & Artillery Post Stable & \\
\hline 387 & 1907 & Artillery Gun Shed & \\
\hline 388 & 1907 & Artillery Work Shop & \\
\hline 400 & 1907 & Bachelor OQ & \\
\hline 402 & 1903 & Gillis Hall/Artillery Post Bks & \\
\hline 403 & 1889 & Artillery Post Admin Bldg & \\
\hline 404 & 1902 & Fremont Hall/Artillery post Bks & \\
\hline 405 & 1910 & Gym/Artillery Post Exchange & \\
\hline 406 & 1909 & Artillery Bank Bks & \\
\hline 407 & 1907 & Artillery Post Bks & \\
\hline 408 & 1909 & Artillery Guard House & \\
\hline
\end{tabular}




\begin{tabular}{|c|l|l|l|}
\hline Bldg\# & Year Built & Original Use & $\begin{array}{l}\text { District (if other } \\
\text { than Main Post) }\end{array}$ \\
\hline 409 & 1889 & Gillis Hall/Artillery Post Bks & \\
\hline 410 & 1897 & Rose Hall/Artillery Post Bks & \\
\hline 411 & 1889 & Waybur Hall/Artillery Post Bks & \\
\hline 425 & 1909 & NCO Qtrs & \\
\hline 426 & 1909 & NCO Qtrs & \\
\hline 500 & 1889 & Hosp/Post HQ (additions) & \\
\hline 505 & 1909 & Hosp NCO Qtrs & \\
\hline 507 & 1891 & Hosp Steward Qtrs & \\
\hline 509 & 1910 & Isolation Hospital & \\
\hline 550 & 1891 & Magazine & \\
\hline 748 & 1907 & Polo Bungalow & MAA \\
\hline 1020 & 1911 & Quarters for Packers & PC \\
\hline 1022 & 1914 & Blacksmith Shop & PC \\
\hline
\end{tabular}

Table 22. 1927-1940 Thematic Group

\begin{tabular}{|c|l|l|l|}
\hline Bldg\# & Year Built & Original Use & $\begin{array}{l}\text { District if other } \\
\text { than Main Post }\end{array}$ \\
\hline $1 G$ & 1935 & Garage & \\
\hline 30 & 1940 & Garage & \\
\hline 31 & 1940 & Garage & \\
\hline 40 & 1934 & Student Officers' Apts & \\
\hline 41 & 1934 & Student Officers' Apts & \\
\hline 46 & 1940 & Garage & \\
\hline 47 & 1940 & Garage & \\
\hline 48 & 1940 & Garage & \\
\hline 70 & 1934 & Field OQ & \\
\hline 72 & 1934 & Field OQ & \\
\hline 74 & 1934 & Field OQ & \\
\hline 76 & 1934 & Field OQ & \\
\hline 78 & 1934 & Field OQ & \\
\hline 80 & 1934 & Field OQ & \\
\hline 82 & 1934 & Field OQ & \\
\hline 102 & 1940 & Garage & \\
\hline & & & \\
\hline
\end{tabular}




\begin{tabular}{|c|c|c|c|}
\hline Bldg\# & Year Built & Original Use & $\begin{array}{l}\text { District if other } \\
\text { than Main Post }\end{array}$ \\
\hline 106 & 1934 & Student Officers' Apts & \\
\hline 108 & 1934 & Student Officers' Apts & \\
\hline 112 & 1940 & Garage for $110 \& 114$ & \\
\hline 116 & 1940 & Garage for 118 & \\
\hline 118 & 1934 & Student Officers' Apts & \\
\hline 125 & 1939 & Dbl NCO Qtrs & \\
\hline 126 & 1939 & Dbl NCO Qtrs & \\
\hline 127 & 1939 & Garage for 125 & \\
\hline 128 & 1939 & Garage for 126 & \\
\hline 129 & 1939 & Dbl NCO Qtrs & \\
\hline 130 & 1939 & Dbl NCO Qtrs & \\
\hline 131 & 1939 & Garage for 129 & \\
\hline 132 & 1939 & Garage for 130 & \\
\hline 133 & 1939 & Dbl NCO Qtrs & \\
\hline 134 & 1939 & Dbl NCO Qtrs & \\
\hline 135 & 1939 & Garage for 133 & \\
\hline 136 & 1939 & Garage for 134 & \\
\hline 137 & 1939 & Dbl NCO Qtrs & \\
\hline 138 & 1939 & Dbl NCO Qtrs & \\
\hline 139 & 1939 & Garage for 137 & \\
\hline 140 & 1939 & Garage for 138 & \\
\hline 141 & 1939 & Dbl NCO Qtrs & \\
\hline 142 & 1939 & Dbl NCO Qtrs & \\
\hline 143 & 1939 & Garage for 141 & \\
\hline 144 & 1939 & Garage for 142 & \\
\hline 153 & 1938 & Dbl NCO Qtrs & \\
\hline 154 & 1940 & Garage & \\
\hline 157 & 1931 & Dbl NCO Qtrs & \\
\hline 158 & 1940 & Garage & \\
\hline 159 & 1931 & Dbl NCO Qtrs & \\
\hline 160 & 1931 & Dbl NCO Qtrs & \\
\hline 161 & 1931 & Dbl NCO Qtrs & \\
\hline 162 & 1931 & Dbl NCO Qtrs & \\
\hline
\end{tabular}




\begin{tabular}{|c|c|c|c|}
\hline Bldg\# & Year Built & Original Use & $\begin{array}{l}\text { District if other } \\
\text { than Main Post }\end{array}$ \\
\hline 163 & 1940 & Garage & \\
\hline 164 & 1931 & Dbl NCO Qtrs & \\
\hline 200 & 1940 & Patton Hall/Academic Bldg & \\
\hline 206 & 1933 & Post Theater & \\
\hline 248 & 1938 & Garage & \\
\hline 401 & 1943 & Garage & \\
\hline 415 & 1930 & Double NCO Q & \\
\hline 416 & 1930 & Double NCO Q & \\
\hline 417 & 1930 & Double NCO Q & \\
\hline 418 & 1930 & Double NCO Q & \\
\hline 419 & 1930 & Double NCO Q & \\
\hline 420 & 1930 & Double NCO Q & \\
\hline 422 & 1930 & Double NCO Q & \\
\hline 423 & 1930 & Double NCO Q & \\
\hline 424 & 1930 & Double NCO Q & \\
\hline 430 & 1932 & Fire Station & \\
\hline 431 & 1940 & Garage & \\
\hline 432 & 1934 & Student Officers' Apts & \\
\hline 433 & 1934 & Student Officers' Apts & \\
\hline 434 & 1940 & Garage & \\
\hline 435 & 1930 & Student Officers' Apts & \\
\hline 436 & 1930 & Student Officers' Apts & \\
\hline 437 & 1930 & Student Officers' Apts & \\
\hline 438 & 1928 & Student Officers' Apts & \\
\hline 439 & 1928 & Student Officers' Apts & \\
\hline 440 & 1928 & Student Officers' Apts & \\
\hline 441 & 1928 & Student Officers' Apts & \\
\hline 442 & 1940 & Garage & \\
\hline 443 & 1940 & Garage & \\
\hline 444 & 1928 & Student Officers' Apts & \\
\hline 510 & 1931 & Nurses' Qtrs/Grimes Hall & \\
\hline 520 & 1939 & Dbl NCO Q & \\
\hline 521 & 1940 & Garage & \\
\hline
\end{tabular}




\begin{tabular}{|c|c|c|c|}
\hline Bldg\# & Year Built & Original Use & $\begin{array}{l}\text { District if other } \\
\text { than Main Post }\end{array}$ \\
\hline 523 & 1939 & Dbl NCO Q & \\
\hline 525 & 1930 & Dbl NCO Q & \\
\hline 527 & 1940 & Garage & \\
\hline 529 & 1931 & Dbl NCO Q & \\
\hline 531 & 1931 & Dbl NCO Q & \\
\hline 533 & 1940 & Garage & \\
\hline 535 & 1939 & Dbl NCO Q & \\
\hline 550 & 1891 & Magazine & \\
\hline 741 & 1932 & Marshall Field Hangar & MAA \\
\hline 755 & 1934 & NCO Q & MAA \\
\hline 757 & 1934 & NCO Q & MAA \\
\hline 759 & 1934 & NCO Q & MAA \\
\hline 760 & 1934 & Barracks & MAA \\
\hline 761 & 1934 & NCO Q & MAA \\
\hline 763 & 1934 & NCO Garages & MAA \\
\hline 765 & 1934 & NCO Q & MAA \\
\hline 767 & 1934 & NCO Q & MAA \\
\hline 780 & 1934 & $\mathrm{OQ}$ & MAA \\
\hline 782 & 1934 & $\mathrm{OQ}$ & MAA \\
\hline 784 & 1934 & OQ & MAA \\
\hline 786 & 1934 & OQ & MAA \\
\hline 788 & 1934 & $\mathrm{OQ}$ & MAA \\
\hline
\end{tabular}

Table 23. WPA Camp Thematic Group

\begin{tabular}{|c|l|l|l|}
\hline Bldg\# & $\begin{array}{l}\text { Year } \\
\text { Built }\end{array}$ & Original Use & $\begin{array}{l}\text { District if other } \\
\text { than Main Post }\end{array}$ \\
\hline 313 & 1935 & Civilian Personnel Bldg & \\
\hline 315 & 1935 & Warehouse & \\
\hline 317 & 1935 & Warehouse & \\
\hline 319 & 1936 & Instruction Bldg & \\
\hline
\end{tabular}


Table 24. World War II Build-Up Thematic Group.

\begin{tabular}{|c|l|l|l|}
\hline Bldg\# & $\begin{array}{l}\text { Year } \\
\text { Built }\end{array}$ & Original Use & $\begin{array}{l}\text { District if other } \\
\text { than Main Post }\end{array}$ \\
\hline 29 & 1941 & Red Cross Bldg & \\
\hline 743 & 1941 & Airfield Operations Bldg & MAA \\
\hline 751 & 1941 & Vehicle Storage Shed & MAA \\
\hline
\end{tabular}

Table 25. Recommended Non-Contributing Buildings Ineligible for NRHP.

\begin{tabular}{|c|c|c|}
\hline Bldg\# & Year Built & Original Use \\
\hline 180 & 1914 & Dry Cleaning \\
\hline 181 & 1930 & Dry Cleaning Plant \\
\hline 182 & 1940 & Flammable Storage \\
\hline 184 & 1941 & Laundry Boiler House \\
\hline 209 & 1936 & Inflammable Materials Storehouse \\
\hline 312 & 1930 & Open Warehouse \\
\hline 316 & 1929 & Storehouse \\
\hline 334 & 1897 & QM Garage \\
\hline 336 & 1897 & Ambulance Shed \\
\hline 338 & 1904 & Wagon/Lumber Shed \\
\hline 354 & 1917 & Gas Station \\
\hline 390 & 1944 & Sewage Treatment Plant \\
\hline 392 & 1944 & Sewage Pumping Station \\
\hline 550 & 1891 & General Storehouse \\
\hline 630 & 1917 & Officers Family Housing \\
\hline 632 & 1931 & Operations General Purpose \\
\hline 634 & 1929 & Term Equipment BIdg \\
\hline 754 & 1941 & Storehouse \\
\hline 928 & 1941 & Small Arms Pyro Magazine \\
\hline 930 & 1941 & High Explosives Magazine \\
\hline 931 & 1941 & Small Arms Pyro Magazine \\
\hline 932 & 1941 & Small Arms Pyro Magazine \\
\hline 933 & 1941 & Small Arms Pyro Magazine \\
\hline 934 & 1941 & High Explosives Magazine \\
\hline 935 & 1941 & Small Arms Pyro Magazine \\
\hline 936 & 1941 & Small Arms Pyro Magazine \\
\hline
\end{tabular}




\begin{tabular}{|c|l|l|}
\hline \multicolumn{1}{|l|}{ Bldg\# } & Year Built & Original Use \\
\hline 937 & 1941 & Small Arms Pyro Magazine \\
\hline 938 & 1929 & Small Arms Pyro Magazine \\
\hline 939 & 1930 & Small Arms Pyro Magazine \\
\hline 940 & 1941 & Small Arms Pyro Magazine \\
\hline 941 & 1927 & Small Arms Pyro Magazine \\
\hline 1671 & 1941 & Maintenance Shed \\
\hline 2269 & 1929 & Open Warehouse \\
\hline 2592 & 1941 & Sewer/Water Treatment Plant \\
\hline 2598 & 1941 & Water Well/Pump Bldg \\
\hline 2599 & 1941 & Water Well/Pump Bldg \\
\hline 3203 & 1929 & Water Well/Pump Bldg \\
\hline 3204 & 1943 & Water Well/Pump Bldg \\
\hline 3205 & 1937 & Water Well/Pump Bldg \\
\hline 3208 & 1929 & Facilities Engineers Storehouse \\
\hline
\end{tabular}




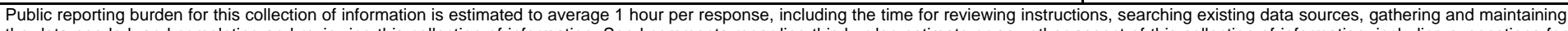

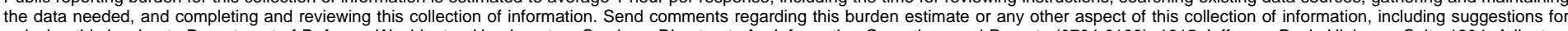

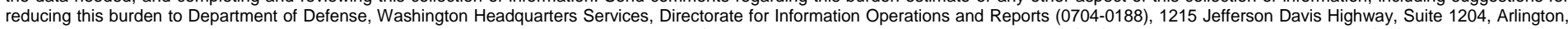

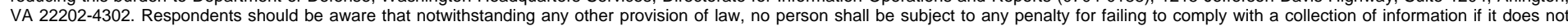
display a currently valid OMB control number. PLEASE DO NOT RETURN YOUR FORM TO THE ABOVE ADDRESS.
1. REPORT DATE (DD-MM-YYYY)
2. REPORT TYPE
3. DATES COVERED (From - To)

30-09-2009

Final Miscellaneous Paper

\section{TITLE AND SUBTITLE}

Comprehensive Inventory and Determinations of Eligibility for Fort Riley Buildings:

1857-1963

5a. CONTRACT NUMBER

5b. GRANT NUMBER

5c. PROGRAM ELEMENT NUMBER

\section{AUTHOR(S)}

Susan I. Enscore and Julie L. Webster

5d. PROJECT NUMBER

146503

5e. TASK NUMBER

MIPR7KDATENV14

5f. WORK UNIT NUMBER

Work Unit 146503

7. PERFORMING ORGANIZATION NAME(S) AND ADDRESS(ES)

U.S. Army Engineer Research and Development Center

8. PERFORMING ORGANIZATION REPORT NUMBER

Construction Engineering Research Laboratory

ERDC/CERL MP-09-1

P.O. Box 9005

Champaign, IL 61826-9005

9. SPONSORING I MONITORING AGENCY NAME(S) AND ADDRESS(ES)

10. SPONSOR/MONITOR'S ACRONYM(S)

Conservation and Restoration Branch -

Environmental Division

404 Holbrook Ave.

Fort Riley, Kansas 66442

11. SPONSOR/MONITOR'S REPORT

NUMBER(S)

\section{DISTRIBUTION / AVAILABILITY STATEMENT}

Approved for public release; distribution is unlimited.

\section{SUPPLEMENTARY NOTES}

\section{ABSTRACT}

This report represents the public release version of ERDC/CERL TR-09-37: “Comprehensive Historical and Architectural Documentation Report for Fort Riley, Kansas.” It inventories all buildings and structures constructed at Fort Riley, Kansas, from 18551963, with the exception of buildings already covered under national Advisory Council on Historic Preservation (ACHP) Program Comments. In three separate studies (1993-1994, 2007, and 2008), ERDC-CERL inventoried and evaluated 373 properties on the installation that were constructed during 1855-1963. Determinations of Eligibility (DOE) to the National Register of Historic Places (NRHP) were then made, based on the significance of the buildings and the degree to which they retain their integrity for conveying that significance. As a result, 272 of those buildings and structures have been determined to be eligible for inclusion in the NRHP.

\section{SUBJECT TERMS}

Fort Riley, KS, National Register of Historic Places (NRHP), cultural resources management, historic preservation, historic buildings, architectural survey

16. SECURITY CLASSIFICATION OF:

a. REPORT

Unclassified

\section{b. ABSTRACT}

Unclassified

\section{c. THIS PAGE}

Unclassified
17. LIMITATION OF ABSTRACT

UU

\section{NUMBER} OF PAGES

217 19a. NAME OF RESPONSIBLE PERSON

19b. TELEPHONE NUMBER (include area code) 